Симонян Г.С., Пирумян Г.П.

\title{
НОВОЕ СУЖДЕНИЕ \\ О ГЕНЕЗИСЕ НЕФТИ
}

EPEBAH

2021 
УДК 552.578.2.061.3

ББК 26.343.1

C 375

Монография публикуется по заказу РАЕ

Рецензенты:

Тимурзиев А.И. - доктор геолого-минералогических наук, академик РАЕН

Сианисян Э.С. - доктор геолого-минералогических наук, профессор

Информация об авторах:

Симонян Г.С.- кандидат химических наук, доцент, профессор РАЕ, академик МАИН

Пирумян Г.П.- доктор технических наук, профессор, академик РАЕН

Симонян Г.С., Пирумян Г.П.

С 375 Новое суждение о генезисе нефти / Г.С.Симонян, Г.П.Пирумян.- Ер.: Копи принт, 2021.- 288 с.

Рассмотрено образование нафтидов в свете абиогенной теории образования нефти. Приведены аргументы против биогенной теории образования нефти. Обсуждаются физико-химические свойства и химический состав нефти. Рассматривается роль азота в генезисе нефти. Показано, что залежи нефтей являются фрактальной, хородинамической и геоинформационной системами. Рассматривается также загрязнение и деградация нефти в гидросфере. Монография может быть рекомендована для специалистов и научных работников в области теории генезиса нефти. Она может быть полезна аспирантам, магистрантам и студентам высших учебных заведений, образовательных учреждений соответствующего профиля.

УДК 552.578.2.061.3

ББК 26.343.1

ISBN 978-9939-875-45-3

(C) Симонян Г.С., 2021

(C) Пирумян Г.П., 2021 


\section{ПРЕДИСЛОВИЕ}

Монография посвящена эндогенному образованию нафтидов в свете абиогенной теории образования нефти. Многочисленные теории происхождения нефти делятся на две основные категории-биогенное и абиогенное образование нефти. В начале книги рассматривается биогенная теория образования нефти. Приведены аргументы против биогенной теории образования нефти. Описаны физико-химические свойства нефти и газа. Подробно рассматривается химический состав нефти. Подробно показана роль $\mathrm{C}-\mathrm{H}-\mathrm{O}-\mathrm{S}-\mathrm{N}-\mathrm{V}-\mathrm{Ni}$ системы в генезисе абиогенной нефти. Рассматривается роль азота и воды в образовании нефти. Рассматриваются коллекторы и ловушки нефти. В отдельной главе описываются методы обнаружения нефтяных залежей. Там же рассматриваются геоэкологические аспекты повышения нефтеотдачи пластов. Авторы подробно описывают свои подходы к залежам нефтей и нефть как фрактальная, хородинамическая и геоинформационная системы. Рассматривается также загрязнение и деградация нефти в гидросфере.

Монография обобщает многолетние работы авторов в области теории генезиса нефти.

Авторы благодарят Российскую Академию Естествознания, всех коллег и специалистов за отзыв и ценные предложения. 


\section{ВВЕДЕНИЕ}

Нафтиды широко распространены на Земле и встречаются в отдельных местонахождениях в газовом, жидком, полутвердом и твердом состояниях или в виде смеси этих фаз. Любые встречающиеся в природе нафтиды представляют собой химически крайне сложную смесь различных углеводородных соединений с небольшой примесью азота, кислорода и серы. Наибольшее промышленное значение имеют жидкие нафтиды, называемые нефтью, или буквально сырым маслом (crude oil) в отличие от очищенного [1].

Геохимики нефть относят к минералам (лат. слово «minera» означает руда), а нефть и газ - к числу горючих полезных ископаемых.

Нефть относится к группе горных осадочных пород вместе с песками, глинами, известняками, каменной солью и др. Она обладает одним важным свойством - способностью гореть и выделять тепловую энергию. Среди других горючих ископаемых она имеет наивысшую теплотворную способность.

Исходя из близости элементного состава различных видов энергоносителей, нефть вместе с газом независимо от их агрегатного состояния относят к тому же классу горных пород, что и уголь (антрацит, каменный и бурый), а именно к классу - каусто-

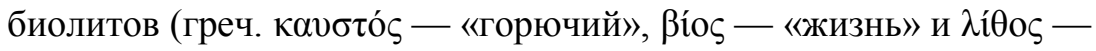
«камень»)

Сырая нефть - это жидкая природная ископаемая смесь углеводородов широкого физико-химического состава, которая содержит растворенный газ, воду, минеральные соли, механические примеси и служит основным сырьем для производства жидких энергоносителей (бензина, керосина, дизельного топлива, мазута), смазочных масел, битумов и кокса. 
Нефть - сложная гетерогенная коллоидно-дисперсная система. Образуется во внутренних частях Земли из глубоких мантийных флюидов и является возобновляемым ресурсом. Нефть представляет собой смесь взаимнорастворенных ближайших гомологов и других соединений друг в друге.

Нефть представляет собой смесь низко- и высокомолекулярных соединений, относящихся к различным гомологическим рядам. Низкомолекулярные соединения представляют собой, в основном, парафиновые, нафтено-парафиновые и ароматические углеводороды. Высокомолекулярная часть нефти состоит из высокомолекулярных парафиновых углеводородов, моно- и конденсированных нафтенопарафиновых, моно- и бициклических ароматических углеводородов ряда бензола и нафталина, смол и асфальтенов. Таким образом, нефть - это сложная многокомпонентная смесь, которая в зависимости от внешних условий проявляет свойства молекулярного раствора или дисперсной системы. В составе нефти обнаружено свыше 1000 индивидуальных органических веществ, содержащих углерод, водород, кислород, азот, серу и более 60 элементов [2-5].

Если принять содержание углерода в различных природных материалах за 100\%, то распределение углерода будет следующим: подавляющее количество углерода 99,5 \% приходится на карбонаты $\left(\mathrm{CaCO}_{3}, \mathrm{MgCO}_{3}\right)$, слагающие породу; 0,47 \% - на углекислый газ, содержащийся в атмосфере; лишь 0,02 \% углерода приходится на каустобиолиты и $0,01 \%$ углерода находится в связанном виде в биосфере [6].

Природный газ может существовать в виде газовых залежей, находящихся в пластах некоторых горных пород, в виде газовых шапок (над нефтью), а также в растворенном или кристаллическом виде в составе естественных газогидратов.

Газ, который извлекается из недр, принято называть попутным. Газ, выделяющийся в промысловых системах, называют нефтяным газом. 


\section{ГЛАВА 1}

\section{1. Теории происхождения нефти}

В настоящее время достаточно хорошо известно, как и в каких геологических условиях скапливается нефть. Вопрос же о происхождении нефти до сих пор окончательно не решен. Решение этого вопроса позволит облегчить поиск и разведку нефтяных месторождений, оценить их запасы, правильно организовать добычу и переработку.

Многочисленные теории о происхождении нефти делятся на две основные категории - (осадочно-миграционная) органического или биогенного и неорганического (абиогенного) происхождения [3,7-13].

\section{1. Биогенная теория образования нефти}

Приверженцы органической гипотезы считают, что источниками происхождения нефти были остатки растений и животных, скопившихся в течение многих миллионов лет на дне водоемов в прошлые геологические эпохи в виде ила [7]. Доводом сторонников биогенной теории является то, что в составе углеводородов обнаружены хемофоссилии - молекулярные структуры биогенной природы.

Сторонниками органической гипотезы образования нефти являются М.В. Ломоносов, К. Энглер, Г. Гёфер, Н.Д. Зелинский, Г. Потонье, А.Д. Архангельский, Г.П. Михайловский, В.И. Вернадский, И.М. Губкин, А.Ф. Добрянский и др., которые считают, что источниками происхождения нефти были остатки растений и животных, скопившихся в течение многих миллионов лет на дне водоемов в прошлые геологические эпохи в виде ила. Отмершие организмы перекрывались в дальнейшем слоями оса- 
дочных пород и под влиянием анаэробных бактерий подвергались биохимическим превращениям. То есть, при фоссилизации (захоронении) органического вещества (остатков зоопланктона и водорослей) сапропелевого типа в водно-осадочных отложениях происходит его постепенное преобразование.

Часть органического вещества в верхних слоях осадочных отложений в условиях ограниченного доступа кислорода в стадии диагенеза в процессе уплотнения, обезвоживании и биохимических, в условиях ограниченного доступа кислорода превращается бактериями в газы $\left(\mathrm{CH}_{4}, \mathrm{CO}_{2}, \mathrm{H}_{2} \mathrm{~S}, \mathrm{NH}_{3}, \mathrm{~N}_{2}\right.$, и др.) В нижних же слоях отложений происходит стадия катагенеза: образование углеводородов из органического вещества и их превращений. Катагенез состоит из трех стадий:

1. протокатагенез, когда пласт органических остатков опускается на глубины до 1,5 - 2 км при медленном подъёме температуры и давления,

2. мезокатагенез или главная фаза нефтеобразования, при этом пласт органических остатков опускается на глубину до 3 - 4 км, где температура поднимается до $150{ }^{\circ} \mathrm{C}$. Здесь органические вещества подвергаются термокаталитической деструкции, в результате чего образуются битуминозные вещества, Далее происходит отгонка нефти за счёт перепада давления и эмиграционный вынос нефти в песчаные пласты-коллекторы и ловушки,

3. апокатагенез керогена, или главная фаза газообразования, когда пласт органических остатков опускается на глубину более 4,5 км, а температура поднимается до $180-250{ }^{\circ} \mathrm{C}$.

Как показано, в результате миграции нефть и газ скапливались в так называемых ловушках, т.е. в малопроницаемых горных породах, образуя нефтяные, нефтегазовые и газовые месторождения. 


\section{2. Абиогенная теория образования нефти}

Впервые теория абиогенного происходения нефти предложена в 1805 году немецким естествоиспытателем Александром Гумбольдом. Он высказал предположение, что нефть образуется на больших глубинах в магматических породах. Гумбольд наблюдал, как нефть сочилась из таких пород в Южной Америке, Венесуэле [14].

В 1866 году французский химик Марселен Бертло высказал предположение, что нефть образовалась в недрах Земли из минеральных веществ. После долгих поисков Бертло удалось синтезировать ацетилен из углерода и водорода в условиях высокой температуры вольтовой дуги:

$$
2 \mathrm{C}+\mathrm{H}_{2} \rightarrow \mathrm{C}_{2} \mathrm{H}_{2} \text {. }
$$

Он обнаружил, что газ ацетилен (ненасыщенный углеводород- $\mathrm{C}_{2} \mathrm{H}_{2}$ ) при низких температурах может переходить в тяжёлые углеводороды. В подтверждение своей теории он провел несколько экспериментов, искусственно синтезировав углеводороды из неорганических веществ. Синтез ацетилена и получение при его пиролизе бензола

$$
3 \mathrm{C}_{2} \mathrm{H}_{2} \rightarrow \mathrm{C}_{6} \mathrm{H}_{6},
$$

а также других ароматических углеводородов (например, стирола, нафталина) стали экспериментальным обоснованием ацетиленовой теории Бертло [14].

На этом основании он сделал вывод о том, что так образовались углеводородные соединения метеоритов и что, по-видимому, подобное происхождение имеют углеводороды на других планетах.

А французский химик Г.Биассон в 1871 году высказал идею о происхождении нефти путем взаимодействия воды, $\mathrm{CO}_{2}$ и $\mathrm{H}_{2} \mathrm{~S}$ c раскаленным железом [14]. 


$$
\begin{gathered}
\mathrm{CO}_{2}+2 \mathrm{H}_{2} \mathrm{~S} \rightarrow \mathrm{CS}_{2}+2 \mathrm{H}_{2} \mathrm{O} \\
3 \mathrm{Fe}+4 \mathrm{H}_{2} \mathrm{O} \rightarrow \mathrm{Fe}_{3} \mathrm{O}_{4}+4 \mathrm{H}_{2} \\
\mathrm{CS}_{2}+4 \mathrm{H}_{2} \rightarrow 2 \mathrm{H}_{2} \mathrm{~S}+\mathrm{CH}_{4} \\
\mathrm{CO}_{2}+4 \mathrm{H}_{2} \rightarrow \mathrm{CH}_{4}+2 \mathrm{H}_{2} \mathrm{O} \\
\mathrm{nCO}_{2}+(2 \mathrm{n}+0.5 \mathrm{~m}) \mathrm{H}_{2} \rightarrow \mathrm{C}_{\mathrm{n}} \mathrm{H}_{\mathrm{m}}+2 \mathrm{nH}_{2} \mathrm{O}
\end{gathered}
$$

Эксперименты по неорганическому синтезу углеводородов, проведенные этими исследователями, в значительной степени способствовали развитию гипотезы минерального происхождения нефти.

В 1877 г. на заседании Русского химического общества с изложением «минеральной» (карбидной) гипотезы происхождения нефти выступил Д. И. Менделеев. Опираясь на конкретные геологические и химические факты, Менделеев писал: «...Образование нефти... более вероятно приписать действию воды, проникающей через трещины, образовавшиеся при подъёме гор, в глубь земли, до того металлосодержащего накалённого ядра земли, которое необходимо признать во внутренности земной...» [15]. По его мнению, вода проникала вглубь земли по трещинам в осадочных и кристаллических породах до магмы, где реагировала с карбидами тяжелых металлов, вообще, и в частности с карбидами железа образуя углеводороды:

$$
\begin{gathered}
\mathrm{CaC}_{2}+2 \mathrm{H}_{2} \mathrm{O} \rightarrow \mathrm{Ca}(\mathrm{OH})_{2}+\mathrm{C}_{2} \mathrm{H}_{2}, \\
\mathrm{Al}_{4} \mathrm{C}_{3}+12 \mathrm{H}_{2} \mathrm{O} \rightarrow 4 \mathrm{Al}(\mathrm{OH})_{3}+3 \mathrm{CH}_{4}, \\
2 \mathrm{LaC}_{2}+6 \mathrm{H}_{2} \mathrm{O} \rightarrow 2 \mathrm{La}(\mathrm{OH})_{3}+2 \mathrm{C}_{2} \mathrm{H}_{2}+\mathrm{H}_{2}, \\
2 \mathrm{Mg}_{2} \mathrm{C}_{3}+8 \mathrm{H}_{2} \mathrm{O} \rightarrow 4 \mathrm{Mg}(\mathrm{OH})_{2}+\mathrm{CH}_{3} \mathrm{C}_{\equiv} \mathrm{CH}+\mathrm{CH}_{2}=\mathrm{C}=\mathrm{CH}_{2}, \\
\mathrm{Be}_{2} \mathrm{C}+4 \mathrm{H}_{2} \mathrm{O} \rightarrow 2 \mathrm{Be}(\mathrm{OH})_{2}+3 \mathrm{CH}_{4}, \\
2 \mathrm{FeC}+3 \mathrm{H}_{2} \mathrm{O} \rightarrow \mathrm{Fe}_{2} \mathrm{O}_{3}+\mathrm{C}_{2} \mathrm{H}_{6} .
\end{gathered}
$$

Анализ газообразных продуктов реакции цементита с водой показал образование сложных углеводородных систем, состоящих из легких парафиновых и нафтеновых углеводородов по следующей схеме: 


$$
\mathrm{Fe}_{3} \mathrm{C}+\mathrm{H}_{2} \mathrm{O} \rightarrow \mathrm{Fe}_{3} \mathrm{O}_{4}+\mathrm{C}_{n} \mathrm{H}_{2 n+2}+\mathrm{C}_{\mathrm{m}} \mathrm{H}_{2 \mathrm{~m}} \cdot
$$

В результате химической реакции карбида железа и воды при $950{ }^{\circ} \mathrm{C}$ и 6.0 ГПа образуются: метан, этан, пропан, изобутан, нбутан, изопентан, н-пентан, изомеры гексана, н-гексан, изомеры гептана, н-гептан, бензол, этилен, ацетилен и пропилен.

В 1892 г. русский учёный В.Д. Соколов предложил так называемую, «космическую» гипотезу [16], согласно которой углеводороды нефти образованы из углерода и водорода в эпоху формирования Земли и других планет. По мере охлаждения Земли углеводороды поглощались ею и конденсировались в земной коре. Впоследствии, когда образовалась земная кора, из магмы выделялись углеводороды, которые по трещинам в земной коре поднимались в верхние части, сгущались и там образовали скопления. В доказательство своей теории Соколов приводил факты обнаружения углеводородов в метеоритах.

Армянские ученые Ю.Р. Каграманов из Института геологических наук НАН РА и А.Г. Егикян из Бюраканской астрофизической обсерватории НАН РА выдвинули новую космическую гипотезу образования и последующего поступления нефти в земную кору [17]. По их мнению, общее количество аккрецируемой нефти в течение миллиона лет составит 10 млрд. т. Размеры насыщенных нефтью пылинок, входящих в атмосферу - 0,01 мкм. Известно, что микрометеориты, в том числе и указанных размеров, могут стимулировать нуклеацию капель в дождевых облаках. Не исключено, что нефть выпадала на Землю в виде нефтяных дождей. Эти комплексы, характеризуемые размерами 0,01 мкм и менее, из-за высокого отношения площади поверхности к массе могут рассеивать возникающее в результате трения тепло и преодолевать атмосферу без существенных изменений, выпадая на поверхность Земли в виде вещества, близкого по составу к нефти или, как минимум, к одной из ее фракций. Ими расматривается, что по геологическим данным в истории Земли 
выделяется 19 крупных ледниковых периодов. Рассматривая распределение скоплений битумов и нефти в Земной коре, ими установлена закономерная связь этих скоплений с ледниковыми периодами. В конце авторы отмечают, что насыщение пород углеводородами из космоса происходило только в пределах суши. Это, прежде всего песчаные берега морей и океанов, песчаные пустыни, эрозионные участки карбонатных массивов и рифов, значительно выступавшие над поверхностью моря. Насыщению УВ подвергались русла палеорек, эрозионные участки метаморфических пород обнаженного фундамента и т.д. Поэтому все толщи, насыщенные битумом, можно рассматривать как потенциально нефтематеринские. Вместе с тем нельзя исключать возможность образования нефти в небольших объемах за счет дегазации Земли. Можно также утверждать, что газовые и газоконденсатные месторождения - это в основном продукты деятельности мантии. Таким образом, рассмотренная гипотеза происхождения нефти по сравнению с ранее предложенными может более обоснованно объяснить картину распределения битумо- и нефтенакоплений в земной коре.

В наше время выдвинут целый ряд других гипотез о неорганическом происхождении нефти и газа в недрах Земли в результате химических реакций непосредственно из углерода и водорода в условиях высоких температур, давлений и каталитического действия оксидов металлов (Fe, Ni и др.). В основном все гипотезы неорганического происхождения нефти и газа базируются на следующих основных положениях: синтез углеводородов возможен на основе оксидов углерода и водорода, которые в тех или иных количествах присутствуют во флюидах, поступающих из недр земли:

$$
\mathrm{nCO}+(2 \mathrm{n}+1) \mathrm{H}_{2} \rightarrow \mathrm{C}_{\mathrm{n}} \mathrm{H}_{2 \mathrm{n}+2}+\mathrm{nH}_{2} \mathrm{O}
$$


в процессе Фишера-Тропша среди побочных продуктов образуется $\mathrm{CO}_{2}$. Степень протекания побочных реакций существенно зависит от природы катализатора и температуры процесса.

В середине XX века трудами выдающихся советских и российских ученых, таких как Н.А. Кудрявцев, В.Б. Порфирьев, А.А. Воробьев, Г.Н. Доленко, П.Н. Кропоткин, Б.М. Валяев, Э.Б. Чекальюк, В.С. Зубков, А.А. Маракушев, А.И. Тимурзиев и других возрождаются различные гипотезы абиогенного (космического, вулканического и магматогенного) происхождения нефти.

Н.А. Кудрявцев выдвинул магматическую гипотезу образования нефти [10]. В мантии Земли - в условиях очень высокой температуры углерод и водород образуют углеводородные радикалы - $\mathrm{CH}, \mathrm{CH}_{2}$ и $\mathrm{CH}_{3}$. По мере понижения температуры в верхних слоях эти радикалы соединяются друг с другом и с водородом:

$$
\begin{aligned}
2 \mathrm{CH}_{*} & \rightarrow \mathrm{C}_{2} \mathrm{H}_{2}, \\
2 \mathrm{CH}_{2^{*}} & \rightarrow \mathrm{C}_{2} \mathrm{H}_{4}, \\
2 \mathrm{CH}_{3^{*}} & \rightarrow \mathrm{C}_{2} \mathbf{H}_{6} .
\end{aligned}
$$

Но Кудрявцев обходит стороной вопрос, откуда, собственно, берется в этих радикалах водород. А.А. Воробьев выдвинул предположение, что в развитии нашей планеты немалую роль играли именно электрические процессы [18]. В результате сильных электрических разрядов возникают частицы плазмы, которые обладают высокой химической активностью. Это обстоятельство, в свою очередь, создает предпосылки для протекания таких реакций, которые невозможны при обычных условиях. По мнению Воробьева, метан при воздействии подземного электрического разряда может подвергнуться частичному дегидрированию, образуя свободные углеводородные радикалы- $\mathrm{CH}, \mathrm{CH}_{2}$ и $\mathrm{CH}_{3}$.

В середине 60-ых годов Э.Б. Чекальюком выдвинута гипотеза о существовании тяжелых углеводородов в осадочном слое земной коры - в верхней мантии [11]. В результате эксперимен- 
тальных исследований и в рамках термодинамической модели систем C-H, C-H-O обоснована возможность термодинамически равновесного существования тяжелых углеводородов в условиях верхней мантии. Исследования В.С. Зубкова показали, что в условиях высоких температур и давлений метан не устойчив и молекулярный вес термодинамически равновесных углеродов увеличивается с ростом давления и температуры [19-22]. С понижением температуры и давления происходит распад тяжелых углеводородов. Во флюиде при мольном соотношении $\mathrm{H} / \mathrm{C}<4$ из газовой фазы выпадает твердый углерод - алмаз или графит по схеме:

$$
4 \mathrm{C}_{\mathrm{n}} \mathrm{H}_{\mathrm{m}} \rightarrow \mathrm{mCH}_{4}+(\mathrm{n}-\mathrm{m}) \mathrm{C}_{\mathrm{Tв}} .
$$

А.А. Маракушев показал, что залежи солей и нефти в осадочных депрессиях пассивных континентальных окраин порождаются глубинными магматическими очагами на щелочной стадии их развития [23]:

$$
\begin{gathered}
\mathrm{NaAlSi}_{2} \mathrm{O}_{6}+\mathrm{Na}_{2} \mathrm{SiO}_{3}+\mathrm{CO}_{2}+2 \mathrm{HCl}+4 \mathrm{H}_{2} \rightarrow \\
\mathrm{NaAlSi}_{3} \mathrm{O}_{8}+2 \mathrm{NaCl}+\mathrm{CH}_{4}+3 \mathrm{H}_{2} \mathrm{O} .
\end{gathered}
$$

Естественно подчеркнуть, что с точки зрения глубинного происхождения ископаемых солей и нефти, этот парагенезис является вполне закономерным следствием общности происхождения газа, нефти и соли.

Показано, что $\mathrm{Fe}_{2} \mathrm{SiO}_{4}$ подвергается флюидной сульфуризации с генерацией сульфидных расплавов. Вовлечение в этот процесс оксидов углерода $\left(\mathrm{CO}_{2}, \mathrm{CO}\right)$ порождает углеводороды:

\section{$7 \mathrm{Fe}_{2} \mathrm{SiO}_{4}+28 \mathrm{H}_{2} \mathrm{~S}+4 \mathrm{CO}_{2} \rightarrow 14 \mathrm{FeS}_{2}+7 \mathrm{SiO}_{2}+22 \mathrm{H}_{2} \mathrm{O}+2 \mathrm{C}_{2} \mathrm{H}_{6}$.}

Подобными процессами определяется наблюдаемая пространственная связь углеводородов и сульфидных руд. Ими вносится существенный вклад в углеводородную специализацию депрессионных структур срединно-океанических хребтов [24]. 
Химическая основа для абиотических процессов нефти - серпентинизация из перидотитов, начиная с метаногенеза с помощью гидролиза оливина в серпентин в присутствии двуокиси углерода. Оливин состоит из форстерита и фаялита. В отсутствии двуокиси углерода образуется водород [25]:

$$
\begin{gathered}
4 \mathrm{Fe}_{2} \mathrm{SiO}_{4}+\mathrm{12Mg}_{2} \mathrm{SiO}_{4}+\mathrm{18H}_{2} \mathrm{O}+\mathrm{CO}_{2} \rightarrow \\
4 \mathrm{Mg}_{6}\left[\mathrm{Si}_{4} \mathrm{O}_{10}\right](\mathrm{OH})_{8}+4 \mathrm{Fe}_{2} \mathrm{O}_{3}+\mathrm{CH}_{4}, \\
\mathrm{Fe}_{2} \mathrm{SiO}_{4}+3 \mathrm{Mg}_{2} \mathrm{SiO}_{4}+5 \mathrm{H}_{2} \mathrm{O} \rightarrow \mathrm{Mg}_{6}\left[\mathrm{Si}_{4} \mathrm{O}_{10}\right](\mathrm{OH})_{8}+\mathrm{Fe}_{2} \mathrm{O}_{3}+\mathrm{H}_{2} .
\end{gathered}
$$

Может образовываться также магнетит и магнезит.

Скорость образования метана и водорода в океанической коре достигает до 10млн т/год.

В работе [26] показано, что начало формирования офиолитового диапира связано с мантийной серпентинизацией дунитгарцбургитовых ультрабазитов в восстановительных условиях в результате образования анионов $\mathrm{OH}^{-}$за счёт окиси углерода и водорода при участии никелиевого катализатора по схеме:

\section{$2 \mathrm{Mg}_{2} \mathrm{SiO}_{4}+\mathrm{Mg}_{2} \mathrm{Si}_{2} \mathrm{O}_{6}+4 \mathrm{CO}+12 \mathrm{H}_{2} \rightarrow \mathrm{Mg}_{6}\left[\mathrm{Si}_{4} \mathrm{O}_{10}\right](\mathrm{OH})_{8}+4 \mathrm{CH}_{4}$}

Образование антигорита с мельчайшими включениями (2-4 мкм) тэнита в условиях мантийной серпентинизации на глубинах 40-50 км подтверждено экспериментальными, термодинамическими данными $\left(\mathrm{T}=450-600^{\circ} \mathrm{C}, \mathrm{P}=13-16\right.$ кбар). В изученных серпентинах обнаружены $\mathrm{H}_{2}, \mathrm{CH}_{4}$.

Превращения метана в высшие н-алканы через дегидрирование метана в присутствии катализатора на основе переходного металла (например, $\mathrm{Fe}, \mathrm{Ni}$ ). Это можно назвать шпинель гидроли-

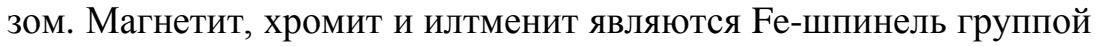
минералов, найденных во многих породах. Высокие концентрации магматических магнетита, хромита и ильменита обеспечивают абиотический крекинг метана в высшие углеводороды в гидротермальных условиях:

$$
3 \mathrm{CH}_{4}+10 \mathrm{Fe}_{3} \mathrm{O}_{4}+4 \mathrm{H}_{2} \mathrm{O} \rightarrow \mathrm{C}_{2} \mathrm{H}_{6}+15 \mathrm{Fe}_{2} \mathrm{O}_{3}+\mathrm{H}_{2} \mathrm{CO}_{3} \text {. }
$$


Можно заключить, что эти углеводороды, взаимодействуя при каталитической активности тонкодисперсных серпентинитов и железо-никелевых соединений (тэнит, пентландит, магнетиты), в условиях постоянно повышенных температур $\left(\mathrm{T}>350^{\circ} \mathrm{C}\right)$ вследствие стадийного магматизма формировали все групповые компоненты нефти [26].

Следует отметить, что А.В. Арутюняном также принимается механизм дегидратации серпентинизированных ультрабазитовых серпентинитов на различных глубинах земной коры, вследствие которого происходит выделение геофлюидов, в том числе водородо- и углеродосодержащие. Этим механизмом автор объясняет и образование нефти в недрах Армении, рассматривая, глубина 513 км как основные нефтегазоносные структуры на территории Армении [27]. Однако, он является сторонником полигенеза. «Представлен комбинированный генезис углеводородов. Генезис неорганических углеводородов обусловлен выделением водородосодержащих компонентов, основным источником которых считается 3-й слой океанической коры. Органические углеводороды генерируются традиционным путем вследствие метаморфизации вышележащих пород морского происхождения. Миграция по глубинным разломам флюидов, газов и углеводородов и их дифференциация происходят в верхних горизонтах коры в породах, обладающих коллекторскими свойствами» [27].

В работах [28,29] показано, что в мантийных условиях из $\mathrm{FeO}$ (вюстита), $\mathrm{CaCO}_{3}$ (кальцита) и воды, наряду с углеродом обнаруживаются также углеводороды, по реакции:

$$
\begin{aligned}
& \mathrm{nCaCO}_{3}+(9 \mathrm{n}+3) \mathrm{FeO}+(2 \mathrm{n}+1) \mathrm{H}_{2} \mathrm{O} \rightarrow \\
& \mathrm{nCa}(\mathrm{OH})_{2}+(3 n+1) \mathrm{Fe}_{3} \mathrm{O}_{4}+\mathrm{C}_{n} \mathrm{H}_{2 n+2}+\mathrm{C}
\end{aligned}
$$

Автор работы [30], опираясь на космическую гипотезу В.Д. Соколова, предполагает, что источником углеводородов (нефти и газа) на Земле является органическое вещество космического происхождения, поступившее на Землю вместе с другим мине- 
ральным веществом из протопланетного газопылевого облака. Суть и причины формирования нефтяных и газовых месторождений и образования месторождений рудных полезных ископаемых одни и те же - это переход рудного вещества от рассеянного состояния к концентрированному в некотором ограниченном объеме разуплотненных пород.

В 2012 г. на 1-х Кудрявцевских Чтениях (Всероссийской научно-практической конференции по глубинному генезису нефти) с сообщением об образовании нефти, как одном из процессов формирования планет, выступил Д.Н. Тимофеев. Опираясь на фундаментальные законы природы и свойства веществ Д.Н. Тимофеев выдвинул ряд гипотез, которые давали объяснение образованию элементов Солнечной системы, механизма попадания образующих нефть элементов в глубь Земли, причин поднятия их к поверхности, закономерности протекания реакций образования нефти [31]. По этим гипотезам химические элементы образовались в результате взрыва нейтронной звезды от которого возникло протопланетное газопылевое облако. При остывании образовавшихся веществ происходила конденсация элементов в кристаллы рыхлого пепла. Газообразные элементы H, N, O адсорбировались на большой поверхности пепла взаимодействовал с ними с образованием химических соединений, в том числе нитридов, гидридов, окислов. Далее частицы пепла под действием сил притяжения собрались в планеты. Таким образом, газы Н, N, О в составе пепла попали вглубь Земли.

Большое значение в понимании процессов эволюции имеет предложенная Д.Н. Тимофеевым гипотеза об структуре ядер планет из слоёв тяжелых элементов в состоянии газа. От распада радиоактивных элементов породы разогрелись, что привело к их ползучести. Радиоактивные элементы $\mathrm{Th}^{232}, \mathrm{U}^{238}$ тяжелые, по этой причине основная масса их пород погрузилась в центр Земли и выделяла большое количество тепловой энергии. При разогреве, 
до $1500-6000^{\circ} \mathrm{C}$ произошел распад веществ центральной части Земли на атомы (атомизация), например, по реакциям:

$$
\begin{gathered}
2 \mathrm{UH}_{3} \rightarrow 2 \mathrm{U} \downarrow+6 \mathrm{H} \uparrow, \\
2 \mathrm{PdO} \rightarrow 2 \mathrm{Pd} \downarrow+2 \mathrm{O} \uparrow, \\
\mathrm{Th}_{3} \mathrm{~N}_{4} \rightarrow 3 \mathrm{Th} \downarrow+4 \mathrm{~N} \uparrow, \\
\text { Бассетит } \mathrm{Fe}\left(\mathrm{UO}_{2}\right)_{2}\left(\mathrm{PO}_{4}\right)_{2} \rightarrow \mathrm{Fe} \uparrow+2 \mathrm{U} \downarrow+2 \mathrm{P} \uparrow+12 \mathrm{O} \uparrow .
\end{gathered}
$$

Все элементы центральных частей планет перешли в газообразное атомарное состояние и расслоились. Центральные части планет при этом очистились от сравнительно лёгких элементов, образовав ядра из слоёв тяжелых элементов.

При определении расположения слоёв различных элементов в ядре Земли Д.Н. Тимофеев открыл существование пятого фазового состояние вещества, наряду с известными (твёрдым, жидким, газообразным, плазмой), которое назвал кристаллическим газом [32]. Такое вещество существует, когда от высокого давления межатомное пространство в газообразных элементах отсутствует. В состоянии кристаллического газа атомы или ионы атомов выстроены в гексагональную решетку и способны заполнить общий объем пространства на $74.05 \%$. Свойства таких веществ существенно отличаются от свойств реальных газов, например, фиксированной плотностью, не зависящей от давления.

Для оценки плотности таких веществ Д.Н. Тимофеев предложил использовать понятие «плотность атома» и рассчитал их численные значения для всех элементов таблицы Д.И. Менделеева. Плотности атомов разные для разных элементов и равны массам атомов, делённых на их объёмы. Плотность вещества в состоянии кристаллического газа равна 0,7405 от плотности его атомов. Характерным свойством для кристаллических газов является отсутствие в них конвективного теплообмена, поскольку они не обладают свойством температурного расширения, что препятствует передаче тепла из ядра к коре Земли. 
Из-за разогрева ядра от радиоактивного распада в архейский период развития Земли произошло разделение элементов на слои, а слои элементов ядра распределились в порядке увеличения плотностей их атомов с глубиной. Поскольку размеры атомов $\mathrm{H}$, $\mathrm{N}, \mathrm{O}$ малы плотности этих элементов в состоянии кристаллических газов значительны и эти элементы в тот период времени не поднялись из ядра Земли, а образовали свои слои в глубине ядра.

При высоком давлении и высокой температуре вещество может находиться в двух состояниях: в состоянии кристаллического газа, когда атомы сжаты в плотную структуру, и межатомное пространство равно $25.95 \%$ (несжимаемое пространство между шарами атомов при плотной гексагональной упаковке) и в состоянии реального газа, когда между атомами межатомное пространство больше $25.95 \%$. При повышении температуры от дальнейшего разогрева ядра происходит переход атомарного вещества слоев из состояния кристаллического газа в состояние реального газа, при этом плотность их уменьшается. В состоянии реального газа последовательность расположения слоев не зависит от размера атома, а зависит только от атомной массы, что определяется законом Авогадро. Это приводит при постоянном нагревании ядра к перестановке слоев элементов из последовательности по плотности атомов в последовательность по нарастанию атомных масс к центру Земли. Перестановка началась примерно 540 миллионов лет назад, что привело к изгнанию слоёв газов H, N, О как элементов с малыми атомными массами, из глубинных горизонтов ядра Земли к его поверхности. У поверхности ядра температура ниже, чем в глубине и элементы H, N, O здесь вновь перешли в состояние близкое к кристаллическому газу, что препятствует их резкому переходу в мантию.

В нижней мантии температуры ниже чем в ядре и здесь вещества могут находиться в виде химических соединений, протекают химические реакции. В непосредственной близости от ядра вещество из которого в дальнейшем образуется нефть 
находится в виде радикалов, а выше в виде газообразных соединения $\mathrm{NO}, \mathrm{N}_{2} \mathrm{O}, \mathrm{N}_{2} \mathrm{O}_{4}, \mathrm{~N}_{2} \mathrm{O}_{5}, \mathrm{HCN}, \mathrm{O}_{3}, \mathrm{O}_{4}, \mathrm{O}_{8}, \mathrm{~N}_{2} \mathrm{H}_{4}, \mathrm{C}_{2} \mathrm{H}_{2}, \mathrm{C}_{2} \mathrm{H}_{4}$, $\mathrm{HN}_{3}$, которые образуются из элементов, $\mathrm{H}, \mathrm{N}, \mathrm{O}$ поднявшихся из ядра Земли или выделившихся результате распада пород нижней мантии карбидов, нитридов, гидридов и оксидов от тепла ядра Земли. Постепенно поднимаясь в мантии, газы трансформируются в другие химические соединения, которые соответствуют условиям (давлению, температуре) в данном месте.

Из-за высоких температур в мантии химические реакции, как правило, обратимы, поскольку энергии частиц выше энергий активации многих реакций, и подвижные вещества состоят из многих компонентов концентрации которых находятся в динамическом равновесии.

По мере поднятия на меньшие глубины в подвижных веществах происходят реакции, изменяющие состав веществ в сторону соединений с меньшим изобарным потенциалом, поскольку на меньших глубинах давления меньше, а температуры, как правило, ниже.

На состав может влиять и то, что ряд элементов в мантии находятся в другом состоянии, например, кислород может находится в виде молекул $\mathrm{O}_{4}, \mathrm{O}_{8}$ которые более инертны, чем бирадикальная форма $\mathrm{O}_{2}[33]$.

При дальнейшем поднятии этих газообразных соединений, давление в них ещё снижается, газы расширяются, из-за этого охлаждаются, и в условиях астеносферы элементы этих газов переходят в наиболее стабильные здесь по термодинамическим характеристикам соединения с большим молекулярным весом, которые получили название «нитронефть». В мантии также синтезируются металлоорганические соединения, органосилоксаны, карбонилы, которые растворяются в нитронефти. В нитронефти присутствуют непредельные углеводороды, перекиси, амины, гидразин, озон и нитропарафины (нитрометан, гексанитроэтан и т.д.), нитроароматические соединения (тринитротолуол, 
гексанитробензол и т.д), нитроамины (гексоген- $\mathrm{C}_{3} \mathrm{H}_{6} \mathrm{~N}_{6} \mathrm{O}_{6}$, октоген- $\left.\mathrm{C}_{4} \mathrm{H}_{8} \mathrm{~N}_{8} \mathrm{O}_{8}\right)$, карбонилы $\mathrm{Fe}(\mathrm{CO})_{5}, \mathrm{Ni}(\mathrm{CO})_{4}$, металлоорганические соединения, кремнеорганические соединения (органосилоксаны), сера, $\mathrm{SO}_{3}$.

При поднятии нитронефти до глубин менее 10 км, нитронефть разлагается с образованием нефти, воды, $\mathrm{N}_{2}, \mathrm{CO}_{2}$ рудных образований, гипсов и известняков. В случае избытка водорода в составе нитронефти происходит образование природного газа. При избытке кислорода нитронефть разлагается без образования углеводородов [33,34].

В работе $[33,35]$ предложена новая концепция по которой в глубинах Земли образуется подвижное вещество, основа которого - смесь различных соединений кремния с водородом - силанов (аналогов углеводородов) которому Д.Н. Тимофеев дал название «силановая нефть». Как у метана, у силана есть ряд гомологов $\mathrm{Si}_{2} \mathrm{H}_{6}, \mathrm{Si}_{3} \mathrm{H}_{8}, \mathrm{Si}_{4} \mathrm{H}_{10}, \mathrm{Si}_{5} \mathrm{H}_{12}, \mathrm{Si}_{6} \mathrm{H}_{14} \ldots$ Он образует и непредельные соединения. Нахождение углерода в глубинах Земли в стабильном состоянии метана диктуется его термодинамическими характеристиками. По этим же законам в глубинах Земли кремний находится в состоянии силана. Большое положительное значение изобарного потенциала силана однозначно показывает на нахождение кремния в состоянии гидридов в мантии Земли, где температура высокая. На поверхности Земли силаны находиться не могут, поскольку самовозгораются или взрываются в контакте с атмосферой, а также реагируют с водой по реакциям:

$$
\begin{aligned}
& \mathrm{SiH}_{4}+2 \mathrm{O}_{2} \rightarrow \mathrm{SiO}_{2}+2 \mathrm{H}_{2} \mathrm{O}, \\
& \mathrm{SiH}_{4}+2 \mathrm{H}_{2} \mathrm{O} \rightarrow \mathrm{SiO}_{2}+4 \mathrm{H}_{2} .
\end{aligned}
$$

Это отличает их от углеводородов, которые разлагаются медленно. Алюминий и железо могут взаимодействовать с поднимающимися веществами в геосферах мантии Земли с образованием подвижных соединений гидридов $\mathrm{AlH}_{3}, \mathrm{FeH}_{3}$ или силинов, например, трисилина алюминия $\mathrm{Al}\left(\mathrm{SiH}_{3}\right)_{3}$ и трисилина железа 
$\mathrm{Fe}\left(\mathrm{SiH}_{3}\right)_{3}$. В поднимающемся подвижном веществе есть кислород, вероятно в свободном состоянии, в виде озона, а также около $1 \%$ нитронефти. Остальные, в том числе тяжелые элементы $\mathrm{V}, \mathrm{Cr}, \mathrm{Ni}$, $\mathrm{Pb}, \mathrm{W}, \mathrm{Pt}, \mathrm{Hg}, \mathrm{U}$..., содержатся в подвижной фазе в малых количествах, в концентрациях, отражающих растворимость их в этих условиях.

Дано объяснение происхождению корней материков и деплетированной мантии под океанами. Показано, что землетрясения в зонах Заварицкого, Беньофа происходят по причине взрывов здесь скоплений силановой нефти, когда она переходит в нестабильное состояние при быстром поднятии. В результате расходования кремния и выпадения $\mathrm{SiO}_{2}$ при окислении силана, в оставшейся подвижной фазе увеличивается процентное содержание соединений углерода, в остатке получается нитронефть, имеющая большое содержание нитрованных углеводородов и некоторое количество остаточных силанов. Разложение нитронефти и силановой нефти происходит с выделением значительной энергии, что приводит к разогреву до высокой температуры окружающих пород, содержащих лёгкие элементы $\mathrm{Na}, \mathrm{K}, \mathrm{Ca}, \mathrm{Mg}$. Породы лёгких элементов взаимодействуют с соединениями нитронефти и силановой нефти с образованием, при быстром разложении, расплавленных силикатных пород (магмы), например, по реакции:

\section{$7 \mathrm{Si}_{3} \mathrm{H}_{8}+24 \mathrm{O}_{2}+\mathrm{Na}_{2} \mathrm{O}+2 \mathrm{AlH}_{3} \rightarrow \mathrm{Na}_{2} \mathrm{O} \cdot \mathrm{Al}_{2} \mathrm{O}_{3} \cdot 6 \mathrm{SiO}_{2}+\mathrm{SiO}_{2}+31 \mathrm{H}_{2} \mathrm{O}$}

$\mathrm{B}$ ходе реакций образуется так же вода, $\mathrm{CO}, \mathrm{CO}_{2}, \mathrm{~N}_{2}$ которые при расширении в горячих пространствах магматических очагов вызывают землетрясения или, при прорыве на поверхность, вулканические проявления.

При разложении силановой нефти, сопровождающемся образованием силикатных пород, оставшаяся небольшая часть подвижной фракции, нитронефть накапливается в виде залежей на глубинах, примерно 5-30 км. Количество силановой нефти, поднявшейся и образовавшей силикатную кору Земли, примерно 
на два порядка больше, чем количество нитронефти, из которой образовались в коре соединения углерода.

Нитронефть может со временем ближе просачиваться к поверхности Земли и разлагаться, образуя залежи углеводородов. Кроме углеводородов, при разложении нитронефти образуются карбонаты, азот, вода, углекислый газ и рудные залежи. Учитывая, что за время существования Земли на поверхность поднялось примерно $0,25 \cdot 10^{21}$ кг углерода, количество нитронефти, поднимающейся из глубины к коре Земли, за год составляет около 55 миллионов тонн.

Другой ветвью реакций при разложении нитронефти, по убеждению Д. Н. Тимофеева является образование из неё углей. Такой процесс протекает в случае если содержание кислорода в нитросоединениях достаточно для окисления значительной части водорода, но недостаточно для полного окисления нитронефти [36].

Уголь образуется из нитронефти, поднявшейся и распространившейся в проницаемых горизонтах в результате реакций поликонденсации, подобно образованию полимеров близких по структуре к фенопластам. Родственное происхождение нефти и углей, а также образование их не из биологических остатков, доказывается наличием в составах близких количеств элементов серы, ванадия и никеля, что не соответствует составу древесины, в которой серы небольшое содержание, а никеля и ванадия нет. Представление об образовании углей из нитронефти содержащей некоторое количество силановой нефти объясняет и наличие в пластах углей прослоек из силикатных пород. Такие прослойки образовались в результате расслоения нитронефти с выделением силановойной фракции в отдельный слой, которая при разложении трансформируется в прослойку силикатной породы. Количество таких прослоек показывает количество излияний нитронефти за историю образования залежи угля. Таким образом, по концепции Д.Н. Тимофеева мантия и кора Земли являются хими- 
ческим реактором, в котором происходит образование нефти угля, природного газа, руд, силикатных пород, воды, азота..., в большой части, из поднимающихся из ядра химических элементов. В центральной части Земли эти элементы оказались во время её формирования из газопылевого облака, а при поднятии вещества многократно трансформируются из одних химических соединений в другие в направлении соединений с меньшим изобарным потенциалом на меньших глубинах [37].

М.А. Лурье и Ф.К. Шмидт утверждают, что сера принимает участие в образовании нефти уже на начальных стадиях нефтегенеза, согласуется с данными о ее наличии в глубинных флюида в виде $\mathrm{H}_{2} \mathrm{~S}$ и $\mathrm{S}[38,39]$. Показано,что взаимодействие $\mathrm{CH}_{4} \mathrm{c} \mathrm{S}$ при мантийных условиях приводит к образованию различных S-coдержащих соединений и более высокомолекулярных углеводородов:

$$
\begin{gathered}
\mathrm{CH}_{4}+4 \mathrm{~S} \rightarrow 4 \mathrm{H}_{2} \mathrm{~S}+\mathrm{CS}_{2}, \\
\mathrm{CH}_{4}+2 \mathrm{~S} \rightarrow 2 \mathrm{H}_{2}+\mathrm{CS}_{2}, \\
\mathrm{nCS}_{2}+(2 \mathrm{n}+0.5 \mathrm{~m}) \mathrm{H}_{2} \rightarrow 2 \mathrm{nH}_{2} \mathrm{~S}+\mathrm{C}_{\mathrm{n}} \mathrm{H}_{\mathrm{m}}, \\
2 \mathrm{C}_{\mathrm{n}} \mathrm{H}_{2 \mathrm{n}}+\mathrm{H}_{2} \mathrm{~S} \rightarrow\left(\mathrm{C}_{\mathrm{n}} \mathrm{H}_{2 \mathrm{n}+1}\right)_{2} \mathrm{~S} .
\end{gathered}
$$

Г.С. Симоняном установлено, что уже на ранних стадиях образования абиогенной нефти $N-N i$ и $S-V$ выполняют системообразующую функцию [3. 40-43].

Принимается, что азот, являясь одним из основных компонентов нефти, принимает участие в образовании нефти во всех стадиях нефтегенеза [40-47]. Так, по расчетам Сорохтина [48] в мантии количество азота приблизительно $4,07 \cdot 10^{21}$ г. В мантийных условиях возможны существования некоторых нитридов. Так, нитрид Fе образуется из смеси Fе и $\mathrm{N}$ при более $1700^{\circ} \mathrm{C}$ и 520 кбар [49], TiN в виде порошка, устойчив до $1300^{\circ} \mathrm{C}$ и 77 кбар [49]. Показано, что $\mathrm{HfN}_{10}$, который одновременно имеет бесконечные крестообразные полимерные $\mathrm{N}$-цепи и молекулы $\mathrm{N}_{2}$ в своей кристаллической структуре, стабилен при умеренном 
давлении выше 23 ГПа и может поддерживаться в качестве метастабильной фазы при атмосферном давлении [51]. Вода, проникая в глубь земли по трещинам в осадочных и кристаллических породах до магмы, реагирует с нитридами тяжелых металлов, образует аммиак:

$$
\begin{aligned}
\mathrm{Ca}_{3} \mathrm{~N}_{2}+6 \mathrm{H}_{2} \mathrm{O} & \rightarrow 3 \mathrm{Ca}(\mathrm{OH})_{2}+2 \mathrm{NH}_{3} \\
\mathrm{TiN}+3 \mathrm{H}_{2} \mathrm{O} & \rightarrow \mathrm{Ti}(\mathrm{OH})_{3}+\mathrm{NH}_{3} .
\end{aligned}
$$

Термодинамическое моделирование эволюции системы С-HN-O [19-22] показало, что азот в $P T-$ условиях нижней мантии становится одним из самых химически активных элементов. В составе мантийного газа относительно много $\mathrm{N}$ - содержащих углеводородов (дициан и дицианацетилен). В составе флюида, кроме $\mathrm{N}_{2}$, содержится значительное количество $\mathrm{NH}_{3}$. В последнее время на основе экспериментальных материалов вскрыта важная особенность летучих соединений $\mathrm{H}, \mathrm{C}, \mathrm{N}, \mathrm{O}$ в продуктах плавления ранней мантии Земли - в силикатных расплавах [52, 53]. Так, в работе [53] показано, что при закалке алюминосиликатного расплава ( $\mathrm{NaAlSi}_{3} \mathrm{O}_{8} 80$ вес. \%) + металлическая фаза $\mathrm{Fe}(\mathrm{FeO} 20$ вес. \% $)+\mathrm{H}+\mathrm{C}+\mathrm{N}$ с добавлением азота $\left(\mathrm{Si}_{3} \mathrm{~N}_{4} 1,3,5,7\right.$ вес. \%), при высоком давлении, температуры и низких значениях химического потенциала кислорода образуются силикатные стекла с высокой концентрацией $\mathrm{CH}_{4}, \mathrm{H}_{2}, \mathrm{NH}_{3}, \mathrm{~N}_{2}$.

Используя эволюционный алгоритм для предсказания USPEX (Universal Structure Predictor: Evolutionary Xtallography) молекул, Артем Оганов и его коллеги смогли доказать, что нетипичные соединения, такие как $\mathrm{N}_{8} \mathrm{H}, \mathrm{N}_{4} \mathrm{H}, \mathrm{N}_{3} \mathrm{H}, \mathrm{N}_{9} \mathrm{H}_{4}, \mathrm{~N}_{2} \mathrm{H}$, $\mathrm{NH}, \mathrm{NH}_{2}, \mathrm{~N}_{3} \mathrm{H}_{7}, \mathrm{NH}_{4}$ и $\mathrm{NH}_{5}$ стабильны при высоком давлении и обладают некоторыми необычными свойствами [54].

При $1000{ }^{\circ} \mathrm{C}$ аммиак реагирует с углём, образуя синильную кислоту $\mathrm{HCN}$ и частично разлагаясь на азот и водород:

$$
\mathrm{C}+\mathrm{NH}_{3} \rightarrow \mathrm{HCN}+\mathrm{H}_{2} \text {. }
$$


Непосредственное образование цианистого водорода из метана и аммиака основано на эндотермической реакции:

$$
\mathrm{CH}_{4}+\mathrm{NH}_{3} \rightarrow \mathrm{HCN}+3 \mathrm{H}_{2} \text {. }
$$

УВ могут синтезироваться и прямым взаимодействием углерода с водородом по реакции:

$$
\begin{gathered}
\mathrm{nC}+0.5 \mathrm{mH}_{2} \rightarrow \mathrm{C}_{\mathrm{n}} \mathrm{H}_{\mathrm{m}}, \\
\mathrm{C}+2 \mathrm{H}_{2} \rightarrow \mathrm{CH}_{4}, \\
16 \mathrm{CH}_{4}+11 \mathrm{C} \rightarrow \mathrm{C}_{2} \mathrm{H}_{6}+\mathrm{C}_{3} \mathrm{H}_{8}+\mathrm{C}_{4} \mathrm{H}_{8}+\mathrm{C}_{5} \mathrm{H}_{12}+\mathrm{C}_{6} \mathrm{H}_{14}+\mathrm{C}_{7} \mathrm{H}_{16} .
\end{gathered}
$$

Как уже показано, в мантийных условиях возможно образование радикалов и бирадикалов $\left(\mathrm{CH}_{3}, \mathrm{NH}_{2}, \mathrm{CH}_{2}, \mathrm{NH}\right)$. Взаимодействия образующихся радикалов с метаном и аммиаком приводят к получению алкиламинов,. которые взаимодействуют с олефинами[55-58]:

$$
\mathrm{CH}_{2}=\mathrm{CHX}+\left(\mathrm{C}_{\mathrm{n}} \mathrm{H}_{\mathrm{m}}\right)_{2} \mathrm{NH} \rightarrow\left(\mathrm{C}_{\mathrm{n}} \mathrm{H}_{\mathrm{m}}\right)_{2} \mathrm{~N}-\mathrm{CH}_{2}-\mathrm{CH}_{2} \mathrm{X} .
$$

Этой реакцией объясняется отсутствие олефинов в подавляющем большинстве нефти.

Следует отметить, что в присутствии алкиламинов с пероксидами происходит полимеризация алкенов, с образованием высокомолекулярных веществ.

$$
\Pi\left(\mathrm{CH}_{2}=\mathrm{CHX}\right) \rightarrow-\left(\mathrm{CH}_{2}-\mathrm{CHX}\right){ }{ }_{\Pi} \cdot
$$

Из газообразных мантийных флюидов получаются почти все азотистые соединения, входящие в состав нефти [59]:

$$
\begin{gathered}
\mathrm{NH}_{3} \rightarrow \text { дифениламин } \rightarrow \text { карбазол, } \\
\mathrm{NH}_{3} \rightarrow \text { анилин } \rightarrow \text { индол, } \\
\mathrm{NH}_{3} \rightarrow \text { пиридин и т.Д., } \\
\mathrm{NH}_{3} \rightarrow \text { пиррол } \rightarrow \text { порфин } \rightarrow \text { VO- и Ni- порфирины. }
\end{gathered}
$$

Абиогенная теория образования нефти имеет много преверженцев из стран СНГ (Украина, Беларусь, Армения, Азербайджан, Казахстан, Узбекистан) и из Вьетнама, Китая, Ирана, Индии. 
Сторонниками абиогенной теории образования нефти являются также Украинские ученые Краюшкин В.А. [60,61], А.И. Вдовиченко и П.П. Ермаков, Н.П. Ермаков, П.Ф. Гожик, А.Е. Лукин, А.П. Петровский, А.Н. Коваль [62-64 ].

Так, Н.Б. Шевченко из Киева с сотрудниками развивают Кавитационно-флуктуационную гипотезу синтеза нефти и формирование месторождений нафтидов [65-67].

Х.Г. Зинатов из Татарстана также придерживается теории глубинного обиогенного образования нефти [68].

Как альтернатива теории органического происхождения нефти с 2011 года по сей день в России развивается авторский проект А.И. Тимурзиева. В рамках проекта «Глубинная нефть» на базе Центральной геофизической экспедиции организовано и проведено 8 Всероссийских конференций по глубинному генезису нефти и газа. В честь увековечивания памяти Н.А. Кудрявцева конференция получила название «Кудрявцевские Чтения». Современный этап развития исследований по глубинному абиогенно-мантийному генезису углеводородов связан как с реабилитацией незаслуженно преданного забвению неорганического учения, так и возрождением этих идей на основе современных достижений науки, включая лабораторно-программное обеспечение и результаты экспериментального моделирования по синтезу неорганических углеводородов в РТ-условиях верхней мантии Земли. Другой особенностью современного этапа развития неорганического учения является всемерное приложение результатов научных исследований в практику геолого-разведывательных работ, выраженное в разработке и внедрении высокоэффективных методов и технологий поисков, разведки и освоения глубинной нефти. Под «Глубинной нефтью» понимается нефть (углеводороды в целом) глубинного, абиогенно-мантийного (неорганического или минерального) происхождения, образующие промышленные скопления в земной коре (осадочном чехле и фунда- 
менте), независимо от глубины залегания и возраста вмещающих пород [69-71].

Таким образом, только теория глубинного абиогенного происхождения углеводородов дает убедительные объяснения всем приведенным фактам. Современные научные взгляды о глубинном происхождении углеводородов подтвердились практическими результатами геологических исследований, обеспечив понимание того, что нефть образуется в мантии и, мигрируя по глубинным разломам в земную кору, она формирует залежи любого строения в породах любого типа.

\section{3. Аргументы против биогенной теории образования нефти}

В работах [69-72] глубоко научно проанализировано и наиболее полно обобщено современное состояние взглядов на происхождение углеводородов. А.И. Тимурзиев обосновывает следующие доказательства глубинного происхождения абиогенной нефти:

- Открытие холодной ветви глубинной дегазации Земли и развитие идей П.Н. Кропоткина является доказательной основой наличия глубинных источников углеводородов и процессов глобальной разгрузки насыщенных флюидов в верхней части земной коры.

- Доказано существование неисчерпаемых источников водорода, углерода и метана в мантии и ядре Земли.

- Открытие геофизическими методами в астеносфере Земли слоев с пониженными скоростями сейсмических волн (волноводы), характеризующиеся повышенной флюидонасыщенностью.

- По результатам экспериментальных работ получили подтверждение данные термодинамических расчетов Э.Б. 
Чекалюка по устойчивости тяжелых углеводородов в термодинамических условиях мантии Земли.

- На основе термодинамического моделирования установлено, что нефть и природный газ возникают в мантии Земли на глубинах не менее 70-100 км при давлениях 20-80 кбар и температуре 800-1800 К.

- Биомаркеры обнаружены в метеоритах, мантийных ксенолитах и фумаролах современных вулканов. Установлены остатки микроорганизмов, питавшихся нефтью, присутствие которых доказано до глубин 5-6 км и более.

- Ярко выраженная геохимическая черта нефти - постоянная и сильная положительная европиевая аномалия, повышенное содержание транзитных элементов ( $\mathrm{Ni}, \mathrm{Co}, \mathrm{Cr}$, $\mathrm{V}$ и др.) и платиноидов свидетельствует о ее мантийном происхождении.

- Многочисленные доказательства присутствия неорганических углеводородов в метеоритах, на планетах солнечной системы, ближнем и дальнем космосе доказывают вторичность жизни на Земле и свидетельствуют о ее возникновении на основе абиогенных углеводородов.

- По данным обобщений В.А. Краюшкина состав мантийных пород содержит метан, этан, пропан, бутан, тяжелые алканы и другие углеводороды.

- В алмазах возрастом 3,1 млрд. лет и глубиной образования 400-500 км установлено значительное содержание углеводородов, а в кимберлитах их концентрация на 1-2 порядка выше.

- Обнаружение метановых «факелов» высотой 600-1000 м над глубинными разломами на дне Марианской и Тонгалезкой впадин, Карибского и Красного морей, Калифорнийского залива и других местах вдоль всей глобальной системы рифтов и разломов. 
- Факты глобальной газогидратности $95 \%$ дна мирового океана и происходящее на наших глазах формирование в современном слое донных осадков гигантских ресурсов метаногидратов, ресурсов которых может хватить на 3,5 млн лет, т. е. практически неисчерпаемые.

- Несопоставимость ресурсного потенциала богатейших нефтегазоносных бассейнов мира с традиционными источниками в пределах осадочного чехла.

- Открытие крупных месторождений в кристаллическом фундаменте (более 450 месторождений, где сосредоточено более $15 \%$ мировых запасов).

- Установлены прямые признаки нефтегазоносности в глубоких и сверхглубоких скважинах, пробуренных на докембрийском щите на глубинах до 9,4 км.

- Обнаружение крупных и гигантских залежей нефти на глубинах более 10,5 км.

\subsection{1. Наличие местораждения нефти в фундаментальных кристаллических породах и ниже так называемого «нефтяного окна»}

В случае органической концепции происхождения нефти предполагается существование определенных литологических толщ, богатых органическим веществом, преобразование которого дает начало нефтеобразующим углеводородам. Однако анализ фактического материала по геологическим разрезам нефтегазоносных районов различных стран мира не позволяет согласиться с этим утверждением. В частности, этому противоречит и тот факт, что нефтевмещающими являются комплексы пород разных формаций (песчанистые, глинистые, карбонатные и другие) либо без органического вещества, либо с незначительным количеством его присутствия. В связи с этим любая попытка ограничить гене- 
зис и локализацию нефти с распространением пород какой-либо формации не подтверждается фактическим материалом. Иногда нефтеносными являются аркозовые гравийники и дресва, образовавшиеся за счет перемыва гранитов и гнейсов докембрия, а также в палеоценовые отложении [9]. В Персидском заливе отсутствует чехол осадочных пород, однако там сосредоточена половина мирового запаса нефти и газа [20]. С помощью геохимической биогенной модели можно объяснить лишь 5-7\% запасов нефти Саудовской Аравии.

В последние годы в Мексиканском заливе на глубинах 8,8-10,5 км, на которых пластовые температуры достигали 280$290{ }^{\circ} \mathrm{C}$ открыты свыше десяти крупных нефтяных месторождений [73-76].

\subsection{2. Соотночения С/Н при переходе от нефтеобразующего органического вещества к нефти}

В рамках биогенной теории не объясняется резкое уменьшение атомного соотношения С/Н при переходе от нефтеобразующего органического вещества к нефти. Содержание углерода в нефтях колеблется в пределах 80-87\%, а водорода в нефтях 10$14.5 \%$. Из других элементов в нефтях чаще всего встречаются сера, кислород и азот. Содержание серы в нефтях достигает 0.03$8 \%$, кислорода в нефтях 0.02-2\%, а азота в нефтях не превышает $1 \%$ [2-6].

Простой математический расчёт показывает, что соотношение пяти главных элементов в нефти соответствует в среднем химической формуле «СН $\mathbf{C H}_{1,76} \mathbf{S}_{\mathbf{0 . 0 1 8}} \mathbf{O}_{\mathbf{0 . 0 0 9}} \mathbf{N}_{0.006}$ »:

$\mathrm{C}: \mathrm{H}: \mathrm{S}: \mathrm{O}: \mathrm{N}=\frac{(80+87)}{(2 \times 12)}: \frac{(10.0+14.5)}{(2 \times 1)}: \frac{(0.03+8)}{(2 \times 32)}: \frac{(0.02+2)}{(2 \times 16)}: \frac{(0.03+1)}{(2 \times 14)}$ $=$

$6.96: 12.25: 0.125: 0.063: 0.041=1: 1.76: 0.018: 0.009: 0.006$ 
В среднем около $18 \%$ массы организмов составляет углерод, $10-10.5 \%$-водород, 70\%- кислород, $0.05 \%$ - сера и $0.3 \%$ - азот [77].

Аналогическим расчетом получаем среднюю химическую формулу живого организма $« \mathrm{CH}_{7} \mathrm{~N}_{0.014} \mathrm{~S}_{0.001} \mathrm{O}_{3} »$ или $« \mathrm{CH}_{1.2} \mathrm{O}_{0.1}$ $\mathrm{N}_{0.014} \mathrm{~S}_{0.001} 2.9\left(\mathrm{H}_{2} \mathrm{O}\right)$ ».

Средняя химическая формула органического вещества в составе клеток микроорганизмов - « $\mathrm{C}_{5} \mathrm{H}_{7} \mathrm{O}_{2} \mathrm{~N} »$ или « $\mathrm{CH}_{1.4-2 \mathrm{x}}$ $\mathrm{O}_{0.4-\mathrm{x}} \mathrm{N}_{0.2} \mathrm{x}\left(\mathrm{H}_{2} \mathrm{O}\right) \gg$ [78].

Получается, что соотношения $\mathrm{C} / \mathrm{H}$ при переходе от живого организма $(\mathrm{C} / \mathrm{H}=0.7-0.8)$ и нефтеобразующего корегена $(\mathrm{C} / \mathrm{H}=0.8$ 1) [79] к нефти $(\mathrm{C} / \mathrm{H}=0.6)$ уменьшается. Уменьшение количества углерода и увеличение содержания водорода можно объяснить процессами катагенеза и термогенеза, в результате чего должно было скапливаться огромное количество сопутствующего углерода (на каждый килограмм нефти должно образоваться 500-700 г коксоподобного углерода). Однако, ни в нефтематеринской, ни в вмещающих породах не обнаруживается накопление образующего углерода. Большое количество кислорода в организмах можно объяснить тем, что кислород в биоматериале в основном находится в составе воды.

Содержание углерода в организмах на 1-2 порядок больше, чем азота, а в нефти - на три порядка. Количество серы в живом организме на три порядка меньше, чем углерода, а в нефти - на два порядка. В рамках биогенной теории происхождения нафтидов трудно объяснить, почему количество азота в биоматериале на порядок выше, чем серы, а содержание его в нефти на 2 порядка ниже. Маловероятно предполагать, что в процессе нефтеобразования одновременно протекают реакции «деазотирования» и «осернения». 


\subsection{3. Наличие металлов и их соединений, в частности VO- и Ni-порфирины в нефти}

В составе нефти обнаружено более 30 металлов [2]. Биогенная теория не объясняет, каким образом и откуда в нефть попадают металлы и их соединения, в частности $V O$ - и $N i$-порфирины $[41,42]$. Согласно биогенной теории, металлопорфирины никеля и ванадия образовались в нефтях в процессе многоступенчатого замещения меди в ее комплексах и железа, и магния в гемах, и производных хлорофилла. Однако жизненно важные металлопорфирины, в том числе гемоглобин, как и хлорофилл, в составе нефти никогда не были обнаружены. Порфирины могут быть абиогенного происхождения: они синтезируются в соответствующих условиях и присутствуют в мантийных ксенолитах, а также входят в состав метеоритов.

Многочисленные факты парагенезиса нафтидов и различных металлов однозначно отвергают осадочно-миграционную биогенную гипотезу. Почти все химические элементы, присутствующие в нефти, есть и в ультраосновной магме и карбонатных породах.

Параллейно с образованием нефти образуются также руды ванадия $[43,80]$, что объясняется тем, что наряду с метаном, аммиаком, сероводородом, серой и азотом ванадий также присутствует в мантийных флюидах [39]. Ванадий занимает первое место среди присутствующих в нефти металлов. Вместе с $\mathrm{Ni}$ он находится в количестве до $10^{-1} \%$, за ними на третьем месте находится $\mathrm{Fe}\left(10^{-2} \%\right)$ [81].

В нефти в свите Офисина в пределах Восточно-Венесуэльского бассейна, среднее содержание ванадия и никеля составляет соответственно 335 и 80 г/т. В девонских нефтях Альберты в Канаде ванадий содержится в среднем 13,6 г/т . В нефтях Иллинойса ванадия $0,35-1,5$ г/т, а в арабских $-9,52-51$ г/т. Зольный остаток нефтей из месторождений на западе США содержит 5-50\% ванадия. Максимальное содержание ванадия в нефти- 
6кг/т. Обогащенные V, Ni тяжелые нефти Венесуэльской провинции тяготеют на севере к рудному поясу Анд, где развиты гидротермальные месторождения ванадиевых и никелевых руд. В пределах Уральского рудного пояса нефти содержат до 569г/т ванадия, а твердые битумы содержат ванадий до 1230 г/т и никель до 1200 г/т. Ванадий присутствует почти во всех месторождениях нефти Западного Казахстана. В Бузачинской нефти содержится ванадий до 300г/т, а в Акбулакской нефти до 400 г/т [82,83]. Основная форма нахождения ванадия в нефтях Западного Казахстана - четырехвалентная, в виде ванадил-иона [82,84]. Соотношение концентраций $\mathrm{V}$ и $\mathrm{Ni}$ в нефтях Западного Казахстана близко к таковому в Волго-Уральской провинции, а также Ирана, Кувейта, Анголы, Колумбии, Эквадора и Калифорнии. Закономерная связь V и Ni в нефтях из районов, удаленных друг от друга на тысячи километров и находящихся в различных географических и климатических условиях, говорит о том, что эти металлы и метан, а также другие углеводороды имеют мантийное происхождение. Исходя из концепции о мантийном происхождении нефти, присутствие в ней металлов, прежде всего $\mathrm{V}$ и Ni может быть объяснено их наличием наряду с метаном, аммиаком, $\mathrm{H}_{2} \mathrm{~S}, \mathrm{~S}$ и $\mathrm{N}$ в мантийных флюидах [19,3*].

Академик Н.А. Шило [85], изучая многочисленные золоторудные месторождения, например, Витватерсранд Южной Африки, Мурунтау в Узбекстане, на глубине 4005 - 4300 м в гранитоидном массиве, показывает факт совместного нахождения золота и нафтидов. Так, в золотых рудниках Витватерсранд откачивают до 500 миллионов кубометров углеводородных газов в год.

Высокотемпературные флюиды метаморфизируют породы, через которые проходят, и испытывают фазовые превращения. При понижении температуры образуются нефтегазовые и рудные залежи, рудные компоненты при этом могут переноситься как с жидкой, так и газовой фазой. Примерами образования нефтегазовых месторождений, месторождений золота и других металлов в 
преддуговых бассейнах может служить залив Кука на Аляске, Гуаякильский в Эквадоре [86]. Известны примеры образования руд в мощных (3-10 км) осадочных толщах, связанные с проникновением высокотемпературных (180-360 $\left.{ }^{\circ} \mathrm{C}\right)$ флюидов по глубинным разломам при отсутствии проявлений магматизма [24]. Надо думать, что указанный механизм массопереноса является причиной того, что в нефтяных залежах находят такие компоненты, как ртуть, редкоземельные элементы, золото, серебро, многие другие компоненты руд. Появление этих веществ в нефтяных залежах лишь отдельное звено в рассматриваемом процессе, они проникают в качестве дополнительных, более глубинных компонентов.

При исследовании геохимии ртути сначала была установлена ртутоносность ряда рудных месторождений различного состава и определена их приуроченность к глубинным разломам мантийного заложения. Были обнаружены ртуть-содержащие газовые и газонефтяные месторождения, которые так же, как и рудные, были приурочены к зонам глубинных разломов. Появление ртути в газах рассматривается как следствие ртутной дегазации Земли углеводородная ветвь ртутной дегазации. Установлен новый генетический тип ртутных месторождений - ртутно-углеводородный, общим для которых является локализация в узлах пересечения глубинных разломов и приуроченность к ртутным поясам. При высоких концентрациях ртути в газах и нефтях на этих месторождениях обычно производится попутное извлечение ртути. Выделены ртуторудные пояса нового типа - по ртутьсодержащим месторождениям различного вещественного состава (рудно-газонефтяным), которые приурочены к линеаментным структурам планетарного масштаба [87]. На основании выше изложенного можно заключить, что совместное образование руд и нафтидов в мантийных слоях Земли позволяет объяснить парагенезис нефти и углеводородных газов с точки зрения абиогенного приосхождения. 
Биогенная теория не объясняет, каким образом и откуда в нефть попадают металлы и их соединения, в частности $V O$ - и $\mathrm{Ni}$ порфирины [41,42]. Согласно биогенной теории, металлопорфирины никеля и ванадия образовались в нефтях в процессе многоступенчатого замещения меди в ее комплексах, железа и магния в гемах, и производных хлорофилла. Однако жизненно важные металлопорфирины, в том числе гемоглобин, как и хлорофилл, в составе нефти никогда не были обнаружены. Порфирины могут быть абиогенного происхождения: они синтезируются в соответствующих условиях и присутствуют в мантийных ксенолитах, а также входят в состав метеоритов.

\subsection{4. Совместное нахождение соли и нефти в форме залежей}

Более трудно объяснить с позиций биогенной гипотезы парагенезис нефти и углеводородных газов с сероводородом, серой, сульфидами тяжелых металлов и ископаемыми солями. Жизнь и соль - антагонисты. В соляных рассолах, из которых выпадает соль в соляных озерах, нет живых организмов, кроме рачков, живущих на поверхности воды. Уже одно это создает трудности для объяснения часто наблюдающегося совместного нахождения соли и нефти как в форме залежей, так и в форме незначительных проявлений нефти в соляных толщах независимо от структурных условий (Сибирская платформа, Рейнский грабен [10], Аван в Армении [88] и др.). Массовые сингенстичные включения нефти и находящиеся под очень большим давлением нефтяных газов в каменные и калийные соли с позиций органической теории совершенно необъяснимы. Естественно подчеркнуть, что с точки зрения глубинного происхождения ископаемых солей и нефти, этот парагенезис является вполне закономерным следствием общности происхождения газа, нефти и соли. 


\subsection{5. Возобновления запасов нефти}

Известны случаи возобновления запасов нефти на давно эксплуатируемых нефтегазовых месторождениях, а потом заброшенных в 40-50-е годы прошлого века. В 1948 году В Татарстане на Ромашкинском нефтяном месторождении разведочная скважина № 3 дала первую нефть По первоначальным оценкам, извлекаемые запасы месторождения составляли 709 млн. т нефти. Однако, на сегодняшний день в Татарстане уже добыто почти в четыре раза больше нефти, чем было предсказано [89]. И заканчиваться татарская нефть не собирается в обозримом будущем. Одна из первых скважин Кавказа Терско-Сунженского района Чечни выдала фонтан нефти в 1895 году, но через несколько лет на этой скважине и на соседних пришлось перейти на насосный способ добычи. До второй мировой войны скважины были сильно обводнены, а многие даже законсервированы. Однако, после войны почти все они снова начали давать практически безводную нефть. Но через полвека скважины уже практически не использовались из-за сильного обводнения, но после чеченских войн дебеты снова значительно возросли. Месторождение «Белый тигр» во Вьетнаме забирает нефть из толщи фундаментальных пород, где нефти быть не должно.

\subsection{6. Органические составляющие нефти в космосе}

Убедительной доказательной базой теории неорганического происхождения нефти может быть наличие углерода, в том числе органических его форм, в ближнем и дальнем космосе (в метеоритах, кометах, планетах Солнечной системы, их спутниках, в межзвездном пространстве, туманностях и соседних галактиках), где нет биогенного вещества [90-95].

Вселенная столь многообразна, что в ее просторах может происходить все и больше того, что мы можем только предста- 
вить себе. Учитывая, что 95\% Вселенной скрыто (темная материя - нейтрино, барионная темная материя, небарионная темная материя и темная энергия) [96,97] от лицезрения и изучения для человека, наши познания столь же ограничены и столь же не полны. Как показало новое исследование, химические реакции, прежде считавшиеся невозможными в космосе, на самом деле все-таки происходят - открытие, которое может в конечном итоге изменить наше представление о том, как во Вселенной формируются и разрушаются органические вещества.

Химический состав Вселенной зависит от многих факторов, в том числе и от температуры [98].

По мере повышения температуры состав частиц, существующих в атмосфере звезды, упрощается. Так, спектральный анализ звезд с температурой 10 000-50 $000^{\circ} \mathrm{C}$ показывает в их атмосферах линии ионизированных водорода и гелия и ионы металлов. В атмосферах звезд с температурой $5000^{\circ} \mathrm{C}$ обнаруживаются уже радикалы, а в атмосферах звезд с температурой $3800^{\circ} \mathrm{C}$ - даже молекулы оксидов. Химический состав некоторых звезд с температурами 20 000-30 000 С приведен в таблице1. Например, в звезде $\gamma$-Пегаса на 8700 атомов водорода приходится 1290 атомов гелия, 0,9 атома азота и т. д. В спектрах звезд первых 4 классов (самых горячих) преобладают линии водорода и гелия, но по мере понижения температуры появляются линии других элементов и даже линии соединений. Это еще простые соединения: оксиды циркония, титана, а также радикалы $\mathrm{CH}, \mathrm{OH}, \mathrm{NH}$, $\mathrm{CH}_{2}, \mathrm{C}_{2}, \mathrm{C}_{3}, \mathrm{CaH}$ и др. Наружные слои звезд состоят главным образом из водорода. В среднем на 10000 атомов водорода приходится около 1000 атомов гелия, 5 атомов кислорода и менее 1 атома других элементов [99].

Благодаря космическим исследованиям с использованием спутников, космических и наземных телескопов и интерферометров в космосе идентицированы свыше 200 различных молекул, в том числе органические молекулы,входящие в состав нефти. 


\subsubsection{1. Органическое вещество в метеоритах и кометах}

Впервые, в 1834 г. органическое вещество в составе метеоритов выделил Й. Берцелиус при анализе углистого хондрита Ала-ис. Химическими анализами было обнаружено присутствие в метеоритах твердых углеводородов, сложных соединений органики с серой и фосфором. С появлением современных точных аналитических методов, позволяющих улавливать самые незначительные концентрации углеводородов и определять их состав, сведения о содержании углеводородов в метеоритах увеличились во много раз.

Наиболее тщательно и обстоятельно изучались углистые хондриты, значительная часть углерода которых находится в виде органических соединений.

В книге [10] Н.А. Кудрявцев, анализируя работы Г.П. Вдовыкина [100], Д. Нунер и Д. Оро [101] и других [102,103], показывает наличие углеводородов в метеоритах углистых хондрытах и их значение для вопроса генезиса нефти. В работе [84], используя результаты исследований углеродистых веществ в 20 углистых метеоритах показано, что во всех метеоритах присутствуют в различных соотношениях алканы и их изомеры с числом атомов углерода в цепи от $\mathrm{C}_{15}$ до $\mathrm{C}_{30}$. Показано также, что в метеорите Оргей имеется наличие пристана и фитана. Г.П. Вдовкин относит образование углеводородов к периоду, когда углистые хондриты были составной частью астероидов и находились вблизи их поверхности, и связывает этот процесс с поступлением газов $\left(\mathrm{CO}_{2}\right.$, $\mathrm{CH}_{4}, \mathrm{H}_{2}$ и др.) из разогретых недр астероидов и воздействием на газы космических лучей. Подтверждает присутствие в метеоритах различных углеводородов - нормальных алканов и их изомеров и статья Д. Нунер и Д. Оро [101], исследовавшие 30 различных метеоритов и во всех обнаружившие углеводороды в различных количествах. В пяти метеоритах они установили фитан и 
пристан. Р. Леви с сотрудниками [103] путем нагревания метеорита, упавшего в Мексике в 1969 году до 423К получил до 0,007\% углеводородов (метан, бутан, бензол, гексан, толуол, ноктан, ксилол и т. д.). Это преимущественно жидкие ароматические углеводороды, но присутствуют в заметных количествах и алканы от октана до ундекана. Предварительное извлечение газов в вакууме не изменило этих результатов. Большая часть углеводородов выделялась до 423К, после $423 \mathrm{~K}$ они почти не выделялись. Поэтому авторы считают, что полученные углеводороды представляют собой не результат распадения крупных молекул, а природный материал.

Т. Бельский и И. Каплан [102] в 11 углистых хондритах обнаружили ряд углеводородов от метана до гептана. Таким образом, в настоящее время в метеоритах обнаружено присутствие не только твердых, но и очень легких жидких и даже всех газообразных углеводородов. Привлекает также внимание тот факт, что углеводороды и оптически активные вещества, извлеченные из углистых хондритов, содержат углерод, по изотопному составу одинаковый с углеродом нефтей [10]. Приведенные данные показывают, что изопреноидные углеводороды, порфирины и оптически активные вещества в действительности образуются не только из органического вещества, но и абиогенным путем и что этим путем могут образоваться и другие компоненты нефтей сложного строения. В углистых хондрытах найдены следующие органические вещества-нормальные и разветленные алканы, циклоалканы, изопреноиды, циклоалканы, алкены, ароматические углероды, алкилбензолы, нафталин, фенантрены, пирены, карбоновые кислоты, пиримидины, пурины,гунилмочевина, порфирины, аминокислоты [104].

В составе Мурчисонского метеорита - камня, упавшего на Землю в 1969 году, - нашли около 14 тысяч органических соединений. Исследования Мурчисонского метеорита, названного так по имени австралийского городка, рядом с которым он упал, 
ведутся с момента падения. Однако до сих пор ученые искали в составе камня только интересующие их соединения. Авторы новой работы провели крупномасштабный поиск, позволяющий выявить огромное число веществ. Основным методом, который использовали ученые, была масс-спектрометрия.Среди идентифицированных органических веществ авторы обнаружили 70 молекул аминокислот. Экстракт метанола имеет среднюю формулу $\mathrm{C}_{100} \mathrm{H}_{155} \mathrm{O}_{20} \mathrm{~N}_{3} \mathrm{~S}_{3}$ [105].

В составе Чебаркульского метеорита (15 февраля 2013 г в близи г. Челяьинск) найдены оливин (51.8\%), ортопироксен $(21.6 \%)$, клинопироксен $(5.4 \%)$, плагиоклаз $(10.2 \%)$, апатит $(0.5 \%)$, хромит (0.8\%), ильменит (0.3\%), и тролит (5.8\%) [106].

В гексановых экстратах метеорита методом синхронной спектрофлуориметрии показана возможность наличия в черной части образцов сложных органических соединений с сопряженными связями [107].

Высокие давления и температуры имеют место при столкновении метеоритов с землей и с другими космическими телами, планетами. Присутствие соответствующих элементов, не редких во вселенной, обеспечивает возможность синтеза углеводородов в момент столкновения. Были измерены состав газов и углеводородов в образцах метеорита упавшего в снег в Чебаркуле [108]. Например при дегазации при $70{ }^{\circ} \mathrm{C}$ в состав газов неоплавленного осколка Челябинского метеорита, упавшего в снег, присутствуют $\mathrm{He}(0.25 \%), \mathrm{H}_{2}(41.27 \%), \mathrm{CO}_{2}(44.86 \%)$ и углеродоводороды (13.62\%). В составе углеводородов $\mathrm{CH}_{4}(7.12 \%), \mathrm{C}_{2} \mathrm{H}_{6}(0.42 \%)$, $\mathrm{C}_{2} \mathrm{H}_{4}(2.51 \%), \mathrm{C}_{3} \mathrm{H}_{8}(0.06 \%), \mathrm{C}_{3} \mathrm{H}_{6}(1.31 \%), \mathrm{C}_{4} \mathrm{H}_{10}(0.007 \%), \mathrm{C}_{4} \mathrm{H}_{8}$ $(1.10 \%), \mathrm{C}_{5} \mathrm{H}_{12}(0.98 \%), \mathrm{C}_{5} \mathrm{H}_{10}(0.11 \%)$ и $\mathrm{C}_{6} \mathrm{H}_{14}(0.003 \%)$.

Таким образом в метеоритах углеводороды находятся в виде постоянного видоизменения. Одни молекулы расщепляются под действием излучения, другие сшиваются. Поэтому состав углеводородов в метеорите может существенно отличаться от состава 
углеводородов в момент выброса этого вещества с большого космического тела, где условия были другими.

Комета 67P/Чурюмова - Герасименко попала в историю как первая комета, на которую приземлялись роботы с Земли [109]. В 2014 году с помощью космического аппарата «Розетты» на растоянии 200 км от кометы в облако, окружающее ядро кометы, специалисты обнаружили молекулы $\mathrm{CO}, \mathrm{CO}_{2}, \mathrm{SO}_{2}, \mathrm{H}_{2} \mathrm{~S}$, формальдегид, метилизоцианат, ацетон, пропаналь и ацетамид. Также «Розетта» показала наличие полимерных молекул на поверхности кометы, образовавшихся под действием радиации, и отсутствие ароматических соединений. На комете более сотни образований изольда, который превращается в пар с частицами пыли при приближении кометы к Солнцу. Исследовательский модуль Philae, отделившийся от «Розетты» и спущенный на поверхность кометы 67Р/Чурюмова - Герасименко, обнаружил органические молекулы.

При снижении температуры вещества преобразуются в сторону снижения химической энергии, и наоборот. Аналогичные процессы проходят и на всех космических телах. В космосе температура тел комет, метеоритов сильно зависит от излучения звезды, оптических свойств и ориентации. Так, на орбите Земли абсолютно чёрное тело, ориентированное на Солнце имеет температуру $+119{ }^{\circ} \mathrm{C}$, а чёрный вращающийся шарик $+4{ }^{\circ} \mathrm{C}$. Такой шарик на орбите Венеры имеет температуру $+54{ }^{\circ} \mathrm{C}$, а на орбите Меркурия $+172{ }^{\circ} \mathrm{C}$. Вследствие этого при изменении ориентации или приближении (удалении), например, для комет, от звезды происходят значительные температурные изменения космических тел, приводящие к постоянным химическим преобразованиям их состава. Например, при повышении температуры, при приближении кометы к Солнцу, очевидно происходит трансформация органических соединений в сторону образования веществ с большими изобарными потенциалами, непредельных и ароматических соединений, а в дальнейшем коксование, а при удалении и 
охлаждении кометы произойдёт гидрирование соединений, а также множество других реакций с образованием веществ с малым изобарным потенциалом. Закономерность, аналогичная изменению изобарного потенциала при увеличении глубины залегания пород в мантии, показана в [94].

\subsubsection{2 Органическое вещество в составе планет и экзопланет}

Атмосфера Марса состоит из углекислого газа (95\%) с примесями азота (2.7\%), аргона (1.6\%), кислорода $(0.13 \%)$ и других газов. Есть, в частности, и примесь водяного пара.

С помощью орбитальная станция MRO с показано, что в южнополярных слоистых отложениях льда находится погребенный $\mathrm{CO}_{2}$ [110]. Установлены три различные субъединицы $\mathrm{CO}_{2}$ льда, каждая из которых увенчана тонким (10-60 м) ограничительным слоем. Так, фоновый уровень атмосферного метана имеет средние значения 0,69 $\pm 0,25$ частей на миллиард по объему. В четырех последовательных измерениях, охватывающих 60 марсианских дней, наблюдались повышенные уровни метана 7,2 $\pm 2,1$ частей на миллиард. Подразумевается, что Марс эпизодически получает метан из дополнительного неизвестного источника. Специалисты утверждают, что данные Curiosity стали первым серьезным доказательством присутствия метана на Марсе [111].

Большинство природных газов $\left(\mathrm{CH}_{4}, \mathrm{C}_{2} \mathrm{H}_{6}, \mathrm{C}_{3} \mathrm{H}_{8}, \mathrm{CO}_{2}, \mathrm{~N}_{2}\right.$, $\mathrm{H}_{2} \mathrm{~S}$, изобутан, и т. п.) образуют гидраты, которые существуют при определённых термобарических условиях [112]. Преобладающими природными газовыми гидратами являются гидраты метана и диоксида углерода. При атмосферном давлении для устойчивости гидрата метана нужна температура около 193 К. Однако, метангидраты всё же могут довольно долго существовать в условиях низких давлений и при более высокой температуре, но обязательно отрицательной — в этом случае они находятся в ме- 
тастабильном состоянии, их существование обеспечивает эффект самоконсервации - при разложении метангидраты покрываются ледяной коркой, что мешает дальнейшему разложению.

Сообщается, что на атмосфере Юпитера и Сатурна обнаружены метан и бензол [113].

В отличие от Нептуна, недра Урана состоят в основном изо льдов и горных пород. Кроме того, в верхних слоях Урана обнаружены следы этана $\left(\mathrm{C}_{2} \mathrm{H}_{6}\right)$, метилацетилена $\left(\mathrm{CH}_{3} \mathrm{C}_{2} \mathrm{H}\right)$ и диацетилена $\left(\mathrm{C}_{2} \mathrm{HC}_{2} \mathrm{H}\right)$ [100]. Эти углеводороды, как предполагают, являются продуктом фотолиза метана солнечной ультрафиолетовой радиацией. Спектроскопия также обнаружила следы водяного пара, угарного и углекислого газов.

Атмосфера Плутона очень разряжена и состоит из газов, испаряющихся из поверхностного льда, благодаря низким температурам на поверхности, достигающим 50К. Это азот с примесью метана (около 0,25\%), есть также этан, ацетилен и СО (около 0,05-0,1\%) [115]. Под действием жёсткого излучения из них образуются более сложные соединения (например, этан, этилен и ацетилен и т.д.), постепенно выпадающие на поверхность. Вероятно, именно их частицы образуют лёгкую слоистую дымку на высотах до 150 км. Наличие атмосферных газов прослеживается как минимум до высоты 1670 км, а по некоторым непрямым данным - даже до 3000 км.

При достаточно высоких давлениях и низких температурах, метан и прочие органические соединения будут «вмерзать» в лед и формировать особые соединения с водой, так называемые клатраты. Они обладают такой же плотностью, как и лед, благодаря чему они должны будут всплывать к «поверхности» океана и формировать своеобразную «прокладку» между водой и «корой» планеты.

В отличие ото льда, клатраты крайне плохо пропускают через себя тепло, что могло защитить воды Плутона от замерзания. Японские ученые проверили, так ли это на самом деле, 
создав компьютерную модель планеты, учитывавшую существование подобного слоя «теплоизоляции».

Как показали эти расчеты, появление даже тонкой прослойки из замороженного метана резко снизило темпы «побега» тепла в верхние слои коры Плутона. В результате этого океан из жидкой воды просуществовал в его недрах более 4,6 миллиарда лет, не меняясь в размерах, тогда как без подобного слоя он исчез через несколько сотен миллионов лет.

В Солнечной системе, кроме Земли, только на Титане ученые обнаружили озера и моря. Эти водоемы на спутнике наполнены жидким метаном и этаном. Моря и озера образуются благодаря низким температурам на поверхности, достигающем 93.8К. [116].

Титан - самый крупный из 62 спутников Сатурна В атмосфере Титана преобладает азот с примесями метана, которые образуют облака. Водоемы на Титане планетологи открыли при помощи орбитального аппарата Cassini, вращающегося вокруг Сатурна. Моря имеют в длину несколько сотен километров, их глубина достигает сотен метров. Они питаются множеством каналов, являющихся аналогами земных рек. В отличие от морей, озера не питаются реками и образуются, как предполагают исследователи, вследствие углеводородных дождей и поступления жидкости из недр [117].

Авторы статьи [118] оценили состав этих озер.Показано, что главные вещества озер - этан $\left(\mathrm{C}_{2} \mathrm{H}_{6}\right)(\sim 76-79 \%)$, пропан $\left(\mathrm{C}_{3} \mathrm{H}_{8}\right)$ $(\sim 7-8 \%)$, метан $\left(\mathrm{CH}_{4}\right)(\sim 5-10 \%)$, водородный цианид $(\mathrm{HCN})(\sim 2-3$ $\%)$, бутен $\left(\mathrm{C}_{4} \mathrm{H}_{8}\right)(\sim 1 \%)$, бутан $\left(\mathrm{C}_{4} \mathrm{H}_{10}\right)(\sim 1 \%)$ и ацетилен $\left(\mathrm{C}_{2} \mathrm{H}_{2}\right)$ $(\sim 1 \%)$. Расчетный состав озер тогда существенно отличается от того, что ожидалось от моделей, разработанных до исследования Титана космическим кораблем Cassini-Huygens. Углеводородный состав озер Титана (а таких титанов в космосе тьма) является прямым, безапелляционным аргументом в пользу абиогенного генезиса углеводородов. В работе [119] исследованы геоморфологические особенности поверхности Титана, полученные зондом 
Huygens Европейского Космического Агентства. Показано, что некоторые структуры на Титане могут представлять собой криогенные газогидратные вулканы, геоморфологически сходные с грязевыми вулканами на Земле. В обоих случаях их основной движущей силой служит метан - жидкий на Титане, газообразный - на Земле. В качестве твердых поверхностей на Титане выступает водяной лед и газогидраты.

В работе [120] показано, что высокая относительная влажность метана в нижних слоях атмосферы Титана может быть сохранена путем выпаривания из озер, покрывающих только 0.002$0.02 \%$ всей поверхности. Доказано, что в условиях поверхности Титана, метан испаряется достаточно быстро, что береговые линии любого существующего озер потенциально может мигрировать на несколько сотен метров до десятков километров в год.

Граница атмосферы Титана находится примерно в 10 раз выше, чем на Земле. Граница тропосферы располагается на высоте 35 км. До высоты 50 км простирается обширная тропопауза, где температура остаётся практически постоянной, а затем температура начинает расти. Ионосфера Титана имеет более сложную структуру, чем земная, её основная часть располагается на высоте 1200 км. Атмосфера Титана состоит из азота на 98,4 \% и примерно на 1,6 \% из аргона и метана, которые преобладают в основном в верхних слоях, где их концентрация достигает $43 \%$. Имеются также этан, пропан, ацетилен, цианацетилен, метилацетилен, $\mathrm{CO}_{2}, \mathrm{CO}$, гелий. Практически отсутствует свободный кислород [121].

Верхние слои атмосферы Титана сильно подвержены воздействию солнечного ветра, так как Титан не обладает существенным магнитным полем. Кроме того, она также подвержена действию космического излучения и солнечному облучению, под воздействием которых, в частности, ультрафиолета, молекулы азота и метана разлагаются на ионы или углеводородные радикалы. Эти фрагменты, в свою очередь, образуют сложные органи- 
ческие соединения азота или соединения углерода - толины, в том числе ароматические соединения (например, бензол). Также в верхних слоях атмосферы образуется полиин - полимер с сопряжённой тройной связью. Толины не образуются естественным образом на Земле на её современном этапе развития. Обычно обладают красновато-коричневым или коричневато-оранжевым оттенком. «Титановые толины» и «тритоновые толины» являются органическим веществом с высоким содержанием азота, Считается, что они представляют собой смесь различных органических сополимеров. Масса молекул толинов в атмосфере Титана достигает 8000 a. е. м., имеет общую формулу СхHyNz

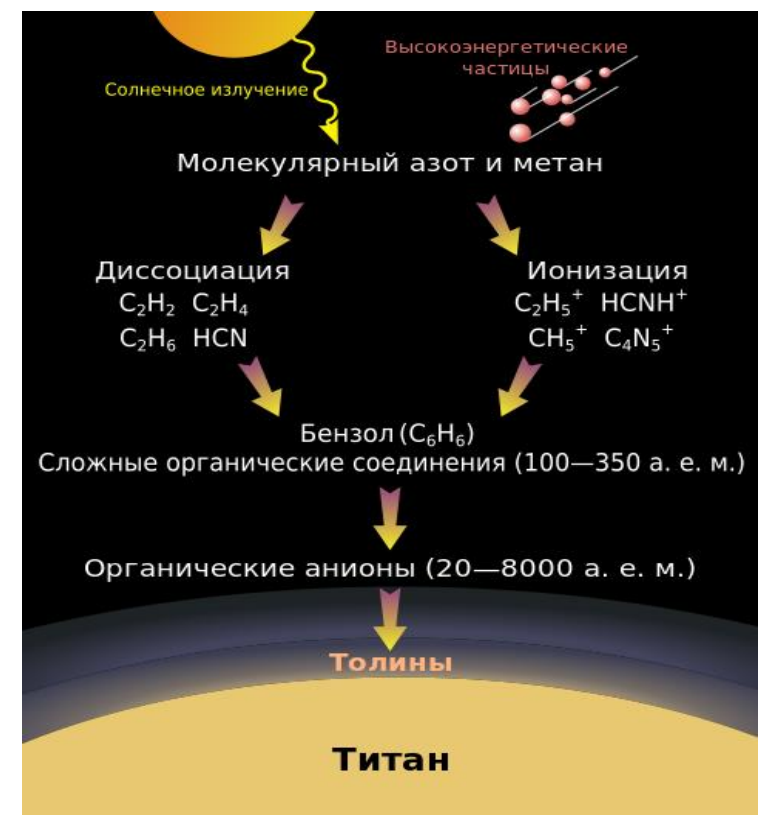

Рис.1.1. Образование толинов в верхней атмосфере Титана, на высоте $\sim 1000 \mathrm{\kappa M}$

Масса Тритона составляет 99,5 \% от суммарной массы всех известных на данный момент спутников Нептуна. Таким образом, 
все остальные его спутники имеют очень незначительную массу. Действующие гейзеры Тритона выбрасывают вещество на несколько километров вверх. Спутник, предположительно, является самым холодным объектом в Солнечной системе из тех, что обладают геологической активностью. Температура на поверхности Тритона составляет в среднем 38 К. Это настолько холодная поверхность, что азот, вероятно, оседает на ней в виде инея или снега. Как и на Плутоне, на Тритоне азотные льды покрывают около $55 \%$ поверхности, 20-35 \% приходится на водяной лёд и 10-25 \% на сухой лёд. Также поверхность Тритона (в основном в южной полярной шапке) покрыта незначительным количеством замёрзших метана и угарного газа - 0,1\% и 0,05\% соответственно. Атмосфера Тритона состоит из азота: 99,9 \% и метана: 0,1\% [122].

Южная полярная шапка из розового, жёлтого и белого материала занимает значительную часть южного полушария спутника. Этот материал состоит из азотного льда с включениями метана и монооксида углерода. Слабое ультрафиолетовое излучение от Солнца действует на метан, вызывая химические реакции, приводящие к появлению розовато-жёлтой субстанции, как толини.

Потенциально обитаемый подледный океан существует на Энцеладе благодаря тому, что его ядро содержит в себе большое количество пор, которые постоянно сжимаются и разжимаются притяжением Сатурна [123]. Учёные, изучающих данные с космического аппарата «Кассини», подтвердили, что в районе южного полюса спутника Сатурна, под толстой ледяной корой - на глубине 30-40 километров - существует водяной океан. Эта вода в виде льда и пара извергается наружу. Изучив эти гейзеры с помощью приборов «Кассини», учёные выяснили, что вода солёная, и в ней содержатся органические молекулы. При том, что температура на поверхности спутника не поднимается выше $-200^{\circ} \mathrm{C}$, в самом океане вода может быть нагрета до ноля. По сло- 
вам учёных, такой комплекс условий вполне допускает возникновение и существование микроорганизмов.

Ученые из США, Франции и Германии определили примерное внутреннее строение карликовой планеты Церера - крупнейшего небесного тела в поясе астероидов между орбитами Марса и Юпитера. Церера открыта в 1801 году итальянцем Джузеппе Пиацци и названа в честь древнеримской богини плодородия.

Внутри Цереры находится крупное каменистое ядро, плотность которого достигает 2,46-2,9 тысячи килограмма на кубический метр. Ядро покрыто оболочкой, толщина которой достигает 70-190 километров, а плотность - 1,68-1,95 тысячи килограмма на кубический метр. Вероятнее всего, внешняя оболочка содержит смесь летучих соединений и более плотных материалов, тогда как ядро Цереры состоит из хондритов.

Астрономы обнаружили на экзопланете органические молекулы. В атмосфере газового гиганта HD 209458b удалось найти воду, метан и углекислый газ. Сообщение об открытии приведено в пресс-релизе Американского космического агентства. Для наблюдения за HD 209458b исследователи использовали телескопы «Хаббл» и «Спитцер». Собранные ими данные подтвердили, что в атмосфере экзопланеты присутствуют вода, метан и углекислый газ. HD 209458b относится к классу так называемых «горячих Юпитеров» и расположена в созвездии Пегаса на расстоянии около 150 световых лет от Солнечной системы. Масса HD 209458b составляет 0,69 массы Юпитера.HD 209458b - уже вторая экзопланета, на которой присутствуют $\mathrm{H}_{2} \mathrm{O}, \mathrm{CO}_{2}$ и $\mathrm{CH}_{4}$ [111]. Первой был газовый гигант HD 189733 b размером с Юпитер. В работе [124] показано, как атомы водорода вылетают из экзосферы планеты при высоких скоростях. 


\subsubsection{3. Органическое вещество в межзвездной среде}

В результате наблюдения за космическими объектами, удалёнными на значительные расстояния получена информация, что они состоят из тех же элементов что и Солнечная система, что вероятно, подтверждает их происхождение по одному механизму, например в результате взрывов нейтронных звезд [33]

Открытия молекул в межзвездной среде происходили одновременно с развитием радиоастрономии. Впервые был открыт водород, который излучает на диапазоне $21 \mathrm{~cm}$. Первой молекулой, которая была открыта в космосе по собственному излучению, была молекула гидроксида ОН, которая излучает на длине волны 18 см. Она была открыта в начале 60-х годов. Первые многоатомные молекулы - молекулы воды и аммиака - с длинами волн порядка 1.35 см открыты в 1967 г. В 1970 году была открыта первая углеродсодержащая молекула - молекула $\mathrm{CO}$, радиолиния которой с длиной волны 2,64 мм наблюдается почти во всех областях межзвездной среды. В 70-е годы были впервые открыты и более сложные органические соединения - формальдегид, метанол и другие. В 1993 г. было обнаружено свыше 80 молекул, наиболее тяжелой была 13-ти атомная молекула $\mathrm{HC}_{11} \mathrm{~N}$.

В составе межзвездных облаков до 2007 г. было обнаружено более 150 различных молекул и частиц, большая часть которых имеет органическую природу (таблица 1.1). Среди обнаруженных в диффузных облаках имеются также формальдегид, ароматические углеводороды, фуллерены, углеродные цепочки, алмазы и сложные ароматические соединения. Обнаружены также цианистый водород, формальдегид, цианацетилен, муравьиная кислота. Из неорганических молекул идентицированы простые вещества углерод, $\mathrm{H}_{2}, \mathrm{O}_{2}$ и $\mathrm{N}_{2}$, Оксиды $-\mathrm{SO}, \mathrm{CO}, \mathrm{NO}, \mathrm{SiO}, \mathrm{N}_{2} \mathrm{O}, \mathrm{SO}_{2}$, $\mathrm{FeO}$, соединения водорода- $\mathrm{LiH}, \mathrm{H}_{2} \mathrm{O}, \mathrm{HCl}, \mathrm{HF}, \mathrm{NH}_{3}, \mathrm{HDO}, \mathrm{HCN}$ и $\mathrm{H}_{2} \mathrm{~S}$. Соли- $\mathrm{KCl}, \mathrm{NaCl}, \mathrm{NaCN}$ [125]. 
Таблий 1.1.

Органические млекулы, обнаруженные в межзвездном пространстве (N число атомов) [103].

\begin{tabular}{|c|c|c|c|c|c|}
\hline $\mathrm{N}=5$ & $\mathrm{~N}=6$ & $\mathrm{~N}=7$ & $\mathrm{~N}=8$ & $\mathrm{~N}=9$ & $\mathrm{~N}=10$ \\
\hline $\mathrm{HCOOH}$ & $\mathrm{CH}_{3} \mathrm{OH}$ & $\mathrm{CH}_{3} \mathrm{CHO}$ & $\mathrm{CH}_{3} \mathrm{COOH}$ & $\mathrm{CH}_{3} \mathrm{CONH}_{2}$ & $\left(\mathrm{CH}_{3}\right)_{2} \mathrm{CO}$ \\
\hline $\mathrm{NH}_{2} \mathrm{CN}$ & $\mathrm{CH}_{3} \mathrm{CN}$ & $\mathrm{CH}_{3} \mathrm{OCH}_{3}$ & $\mathrm{HOCH}_{2} \mathrm{CHO}$ & $\mathrm{CH}_{3} \mathrm{CH}_{2} \mathrm{OH}$ & $\mathrm{NH}_{2} \mathrm{CH}_{2} \mathrm{COOH}$ \\
\hline $\mathrm{CH}_{4}$ & $\mathrm{CH}_{3} \mathrm{SH}$ & $\mathrm{CH}_{2} \mathrm{CHCN}$ & $\mathrm{CH}_{2} \mathrm{CHCHO}$ & $\mathrm{CH}_{3} \mathrm{CH}_{2} \mathrm{CN}$ & $\left(\mathrm{CH}_{2} \mathrm{OH}\right)_{2}$ \\
\hline ц- $\mathrm{C}_{3} \mathrm{H}_{2}$ & $\mathrm{C}_{2} \mathrm{H}_{4}$ & ц- $\mathrm{C}_{2} \mathrm{H}_{4} \mathrm{O}$ & $\mathrm{CH}_{2} \mathrm{CCHCN}$ & $\mathrm{CH}_{2} \mathrm{CHCH}_{3}$ & $\mathrm{CH}_{3} \mathrm{CH}_{2} \mathrm{CHO}$ \\
\hline $\mathrm{HCCNC}$ & $\mathrm{CH}_{2} \mathrm{CNH}$ & & & & \\
\hline & $\mathrm{CH}_{3} \mathrm{NH}_{2}$ & & & & \\
\hline
\end{tabular}

Ученые из Института Макса Планка по радиоастрономии в Бонне (Германия), Корнельского университета (США), и Кельнского университета (Германия), из 3700 спектральных линий, обнаруженных в горячем и плотном облаке газа, известного как "большая молекула Неimat", которое содержит световой новообразованной звезды с помощью метрового телескопа IRAM 30 в Испании выделили 36 линий и обнаружили новые молекулы, этилформиат $\left(\mathrm{C}_{2} \mathrm{H}_{5} \mathrm{OCHO}\right)$ и н-пропил цианида $\left(\mathrm{C}_{3} \mathrm{H}_{7} \mathrm{CN}\right)$, которые представляют собой два различных класса молекулы - сложные эфиры и алкильные цианиды, и они являются наиболее сложными в своем роде, обнаружены в межзвездном пространстве [126]. Немецкие и американские ученые обнаружили в газопылевом облаке Стрелец В2 органические вещества: структурные изомеры пропилцианида. Свое открытие специалисты сделали, наблюдая аномалии в спектрах от излучения, приходящего от Стрелец В2, при помощи телескопа ALMA (Atacama Large Millimeter/ Submillimeter Array), расположенного в Чили. По мнению ученых, их открытие вселяет надежды в возможность обнаружения аминокислот или их следов в межзвездном пространстве. Стрелец В2 находится на расстоянии 26 тысяч световых лет от Солнечной системы рядом с центральной частью Млечного Пути [127]. 
В плотном газопылевом облаке, расположенном по направлению к звезде Cernis 52 в созвездии Персей учеными из испанского Института астрофизики на Канарах (IAC),найден антрацен, самая сложная органика, когда-либо обнаруженная на просторах открытого космоса. Вдохновленные открытием, астрономы намерены теперь поискать в этой же области и другую интересную органику - прежде всего, аминокислоты. Тем более что с точки зрения химии причин этому достаточно: под воздействием обыкновенного ультрафиолетового излучения антрацен может реагировать с водой и аммиаком с образованием не только различных аминокислот, но и других критически важных для жизни соединений [128]. Пару лет назад эта же команда в этой же области пространства обнаружила и другую молекулу - нафталин [129].

В статье в журнале Nature [130] говорится о том, что не только простые, но и сложные органические соединения встречаются во Вселенной повсеместно, поскольку могут производиться не только живыми организмами, но и звёздами в ходе их естественного развития. Профессор Сун Квок и доктор Йонг Цанг из университета Гонк Конга (Китай) показали, что во Вселенной, помимо метана и другой элементарной органики, существует смесь из более сложных алифатических и ароматических (ряда бензола) соединений. Их структура сложна настолько, что соответствует компонентам нефти и каменного угля. Поскольку эти природные ископаемые являются остатками древних живых организмов, их составляющие ранее считались исключительно продуктами жизни. Однако открытие команды астрофизиков свидетельствует о том, что эти вещества могут быть синтезированы в Космосе без какого-либо участия живых организмов [131,132]. Много лет назад исследователи обнаружили инфракрасное излучение, исходящее от звёзд и в межзвёздном пространстве - планетарной туманности NGC 7027 она является одной из самых маленьких планетарных туманностей . Но даже при этом размер NGC 7027 больше расстояния от Земли до Солнца в 14 тысяч раз. 
Название «планетарная туманность» эти объекты получили за их похожесть на планеты. Спектральные характеристики излучения прото-планетарная туманность IRAS 2227215435 долгое время оставались необъяснёнными [133]. На протяжении двух последних десятилетий общепринятым было мнение о том, что они соответствуют простым молекулам полициклических ароматических углеводородов. Но Квок и Цанг, проанализировав спектр излучения, испускаемого звёздной пылью, образующийся в результате взрыва новых звезд V2362 Лебедя и V2361 Лебедя после 251 и 446 дней соответственно, установили, что сложная органика образуется за очень короткий по галактическим меркам период времени, исчисляющийся неделями. Теоретически этот синтез невозможно осуществить в условиях, близких к вакууму, но тем не менее он происходит в околозвездной и межзвездной туманностях.

Группа астрономов во главе с Яном Ками из университета Западного Онтарио (University of Western Ontario) обнаружила молекулы-гиганты при помощи орбитального инфракрасного телескопа Spitzer [134]. В планетарной туманности Тc1, что лежит в созвездии Жертвенника и удалена от нас на расстояние 6500 световых лет, астрономы впервые идентифицировали фуллерены, а именно углеродные молекулы $\mathrm{C}_{60}$ и $\mathrm{C}_{70}$. Планетарная туманность, в которой нашлись фуллерены, это остатки от сброшенной внешней оболочки старой звезды, так что в центре данного образования располагается белый карлик. Учёные считают, что облака фуллеренов - это отражение краткого этапа в жизни звезды, когда она сбрасывала слои, богатые углеродом. По словам Яна, телескопу повезло посмотреть в нужное место в правильное время. Ныне эти фуллерены находятся примерно при комнатной температуре - на идеальном уровне для обнаружения при помощи аппарата Spitzer. Но по космическим меркам этот этап в жизни облака крайне недолог: всего через 100 лет данные 
молекулы будут слишком холодны, чтобы их можно было бы засечь.

Астрономы ALMA во главе с Карином Эбергом наблюдали в субмиллиметровом диапазоне окрестности звезды MWC 480 в созвездии Тельца. Вокруг нее вращается протопланетный диск из газа и пыли, в котором именно сейчас происходит формирование планет. Протопланетный диск MWC 480 содержит большое количество нитрила уксусной кислоты. Этого вещества наряду с синильной кислотой (циановодородом) там очень много [135]. Метилциана, к примеру, хватит, чтобы заполнить все океаны Земли.

Само по себе обнаружение органики в космосе не сенсация. Простые органические молекулы (тот же циановодород) находили и на других планетах, и в межзвездной среде. Важно, что именно эти вещества и именно в таком соотношении, как в диске MWC 480, найдены в кометах Солнечной системы. Важно и то, что в таком большом количестве органика могла сформироваться в протопланетном облаке за очень короткое время.

\subsubsection{4. Химические реакции в межзвездной среде}

В загадочной пучине газа межзвездного пространства космический телескоп Хаббл нашел веские доказательства существования ионизированного бакминстерфуллерена - молекул углерода, которые еще называют бакиболлами [136].

В состав межзвездной среды входят межзвёздный газ, пыль (1 \% от массы газа), межзвёздные магнитные поля, космические лучи, а также тёмная материя. Проблема образования молекул в космических условиях относится к труднейшим проблемам космохимии. В наиболее простом случае могут возникать молекулы водорода при контакте его атомов с твердыми частицами, Межзвездная среда весьма разряженная и достаточно неоднородная среда. Имеются как сильно разложенные и горячие области, так- 
же значительно плотные и холодные области до 10К. Собственно в межзвездной среде, даже в наиболее плотных ее участках, элементы находятся в условиях, далеких от термодинамического равновесия. В силу низкой концентрации вещества химические реакции в межзвездном пространстве крайне маловероятны. Поэтому было высказано предположение, что в построении межзвездных молекул принимают участие частицы космической пыли Температура пыли в межзвездном пространстве около 10 20K. Межзвездная пыль содержит водяной лед, силикаты, графит и, вероятно, оливин, оксиды и сульфиды металлов $(\mathrm{MgO}, \mathrm{CaO}$, $\mathrm{FeO}, \mathrm{FeS}_{2}$ ), покрытые сверху оболочкой из намерзших газов $[99,137]$. Размеры гранул можно определить из их рассеивающих свойств; обычно они меньше 1 мкм. Самое сильное рассеивание обусловлено гранулами 0.3 мкм, но в пыли должны присутствовать также частицы более малых размеров. Гранулы пыли образуются в атмосферах звезд. Газ конденсируется в гранулы таким же образом, как вода в атмосфере Земли может конденсироваться в снег и лед. Затем гранулы выбрасываются в межзвездное пространство давлением излучения. Гранулы могут образовываться также при рождении звезды и, возможно, непосредственно из атомов и молекул в межзвездных облаках. Впервые наблюдения межзвездного льда были проведены в 1973 году в области массивного звездообразования Orion BN/KL [138]. В таблице приведен состав межзвездного льда [139].

При столкновении с пылинкой атомы адсорбируются на поверхности пылинки и вступают в химические реакции с другими атомами и молекулами. Причем эти реакции происходят с помощью квантово-механического подбарьерного перехода, для которого участникам реакции не требуется большой энергии. Таким образом, поверхность космической пыли является прекрасным катализатором для формирования молекул из атомов. 
Таблица 1.2.

Типичный состав межзвездного льда (в массовых долях).

\begin{tabular}{|c|c|c|}
\hline Молекула & $\begin{array}{c}\text { Протозвезда малой } \\
\text { массы }\end{array}$ & $\begin{array}{c}\text { Массивная } \\
\text { протозвезда }\end{array}$ \\
\hline $\mathrm{H}_{2} \mathrm{O}$ & 100 & 100 \\
\hline $\mathrm{CO}$ & 29 & 13 \\
\hline $\mathrm{CO}_{2}$ & 29 & 13 \\
\hline $\mathrm{CH}_{3} \mathrm{OH}$ & 3 & 4 \\
\hline $\mathrm{NH}_{3}$ & 5 & 5 \\
\hline $\mathrm{CH}_{4}$ & 5 & 2 \\
\hline $\mathrm{OCN}$ & 0.3 & 0.6 \\
\hline
\end{tabular}

Но ситуация упрощается, когда атомы, которые составляют молекулу, по очереди прилипают к поверхности пылинки. Они бегают по пылинке в результате тепловых движений, сталкиваются друг с другом, и в процессе этих столкновений начинает расти большая молекула. Под действием ультрафиолетового излучения некоторые молекулы оболочки $\left(\mathrm{H}_{2} \mathrm{O} \mathrm{CH}_{4}, \mathrm{NH}_{3}\right)$ диссоциируют с образованием радикалов - реакционноспособных фрагментов молекул. Эти радикалы могут рекомбинировать с образованием других молекул. В результате длительного облучения может появиться сложная смесь молекул и радикалов Таким образом, при сверхнизких температурах из наиболее легких элементов (H, C, N, O) синтезируются прежде более сложные молекулы, похожие на компоненты нефти.

Однако известно, что химические реакции замедляются с понижением температуры, поскольку уменьшается их энергия для преодоления барьера, или «порога реакции». Но около века назад были найдены процессы, скорость которых увеличивалась не при нагревании, а при охлаждении. В 30-х годах прошлого века Ронни Белл в жидкофазных реакциях с участием атома водорода, обнаружил при низких температурах отклонения от закона Аррениуса и изотопный эффект. Начиная с работ Джеймса Дюара систематические исследования в области криохимии ведутся с 
50-х годов прошлого века, чему способствовало появление ряда новых экспериментальных методик, и прежде всего методов спектроскопии и радиоспектроскопии (ИК, УФ, ЭПР, ЯМР), рентгенографии, колориметрии, микроскопии. При анализе результатов криохимических исследований используют методы квантовой химии и молекулярной динамики.

На сегодняшний день известно сравнительно мало химических реакций, которые протекают при низких температурах самопроизвольно, без специального инициирования. К ним относятся в первую очередь реакции с участием молекулярного фтора:

\section{$2 \mathrm{Na}+\mathrm{F}_{2} \rightarrow 2 \mathrm{NaF}$ (реакция идет при $85 \mathrm{~K}$ )}

и реакции $\mathbf{2} \mathbf{N O}+\mathbf{O}_{\mathbf{2}} \leftrightarrow \mathbf{N}_{\mathbf{2}} \mathbf{O}_{\mathbf{4}}$. Характерно сильное увеличение скорости в интервале 83-90 К.

Для жидкофазных реакций (например, галогенов с олефинами) при низких температурах важное значение приобретают сравнительно слабые межмолекулярные взаимодействия реагентов друг с другом и с молекулами среды, которые при обычных температурах не существенны из-за теплового движения:

\section{$\mathrm{CH}_{3} \mathrm{CH}=\mathrm{CH}_{2}+\mathrm{Cl}_{2} \rightarrow \mathrm{CH}_{3}-\mathrm{CHCl}-\mathrm{CH}_{2} \mathrm{Cl}$ (91 K) [140].}

В работе [141] проводились иследования реакций $\mathrm{CN}$ радикала с $\mathrm{CH}_{4}, \mathrm{C}_{2} \mathrm{H}_{6}, \mathrm{C}_{2} \mathrm{H}_{4}, \mathrm{C}_{3} \mathrm{H}_{6}$ и $\mathrm{C}_{2} \mathrm{H}_{2}$ в температурных интервалах 295 - 700 К. Показано, что эти химические реакции замедляются с понижением температуры, и энергии активации невысокие. В обзоре [125] показано, что при экстраполяции этих измерений к температурам межзвездного пространства: 20К, константа скорости реакции $\mathrm{CN}$ радикала с $\mathrm{C}_{2} \mathrm{H}_{6}$, понижается на 7 порядков. Однако экспериментально получается, что с понижением температуры до 200К скорость реакция уменшается и потом растет. При температуре $25 К$ скорость реакции на 6 порядков больше, чем экстраполированные значения [142]. 
С наибольшей вероятностью при низкой температуре идет процесс, который характеризуется наименьшей энергией активации. Следовательно, понижение температуры в подобных системах может привести одновременно к двум желательным результатам: во-первых, благодаря изменению механизма образования основного продукта реакции облегчается процесс его накопления через низкотемпературные молекулярные комплексы, во-вторых, подавляются побочные процессы, характеризующиеся, как правило, более высокой энергией активации. В конечном счете, реализуется высокоселективный химический процесс вопреки классическим правилам химии. Короче говоря, межзвездное пространство - это своего рода квантово-химическая лаборатория, в которой может появиться целый ряд разнообразных органических молекул, которые астрономы и обнаружили в космосе.

Группе ученых под руководством Двейн Хэрд,из британского Университета Лидса, воссоздав условия космоса в лаборатории, удалось наблюдать реакцию гидроксильного радикала $(\mathrm{OH})$ с метанолом с образованием метокси радикала $\left(\mathrm{CH}_{3} \mathrm{O}\right)$ при 63К [143]. Они обнаружили, что при такой невообразимо низкой температуре газы не только реагируют, но и делают это со скоростью в 50 раз большей, чем при комнатной температуре. Такая реакция с образованием $\mathrm{CH}_{3} \mathrm{O}$ происходит в космическом пространстве, заполненном газом, причем ее причиной может оказаться квантовое туннеллирование. Квантовое туннелирование - «неклассическое явление», которое означает, что волновая функция взаимодействия $\mathrm{OH}$ и метанола имеет ненулевую вероятность проникновения под барьер реакции. То есть система может появиться со стороны «продукта реакции», не пройдя при этом через вершину барьера. Туннелирование вытекает из правил квантовой механики, которые утверждают: частицы не имеют определенных состояний, положений и скоростей, а все эти величины носят вероятностный характер. Так что хотя данная частица с большой вероятностью должна находиться по одну 
сторону барьера, все же у нее есть очень небольшой шанс появится по другую его сторону [144,145].

Показано также [146], что при 10, 50 и 100 К реакция между $\mathrm{CH}_{3} \mathrm{OH}$ и $\mathrm{OH}$ обеспечивает эффективный газофазный маршрут образования газообразного метокси радикала $\left(\mathrm{CH}_{3} \mathrm{O}\right)$, который был недавно обнаружен в холодных, плотных межзвездных облаках. При изучении кинетики реакций гидроксильных радикалов с ацетоном и диметиловим эфиром в температурном диапазоне 63148 К показано, что для ацетона наблюдается большая отрицательная температурная зависимость, причем коэффициент скорости увеличивается в 62 раза при понижении температуры от $148 \mathrm{~K}$ до 79 К. Для диметилэфира коэффициент скорости увеличивается только в 5.5 раз при понижении температуры от $138 \mathrm{~K}$ до 63 К [147]. Коэффициенты скорости для реакций ОН с этанолом и изопропанолом значительно увеличиваются при понижении температуры, примерно в 18 раз в пределах от 293 и 54 К для этанола, в 10 раз в пределах между 298 и $88 \mathrm{~K}$ для реакции $\mathrm{OH}+$ изопропанол [148]. В работе [149] показано, что скорость реакции гидроксильного $(\mathrm{OH})$ радикала с $\mathrm{HC}(\mathrm{O}) \mathrm{OCH}_{3}$ увеличивается на один порядок при понижении от $64 \mathrm{~K}$ до $22 \mathrm{~K}$ и на 3 порядка от 298 К до 22 К. А в работе [125] проанализированы результаты исследований реакционной спасобности углеродсодержащих молекул при сверхнизких температурах, прежде всего кинетика реакций радикалов $\mathrm{C}_{2}$ и $\mathrm{C}_{4} \mathrm{H}$ с углеводородами - от метана до бутана, от этена до бутена и этина до бутина.

Результаты исследований, касающихся новых явлений типа бегущей волны в низкотемпературной химии твердого тела наблюдаются в самых разнообразных твердофазных химических реакциях при температурах жидкого азота или гелия, обсуждаются в работе [150]. Исследованные процессы характеризуются аномально высокими скоростями реакции, которые сравнимы со скоростью самых быстрых реакций горения высокой температуры в классической химии. Предполагается, что механизм этих 
реакций широко встречается в космосе. В обзоре [151] с целью изучения эволюции углеродистых соединений предлагается исследовать физикохимические модели, имитирующие неравновесные процессы на поверхности частиц пыли в межзвездных облаках, вызванные космическими лучами, УФ излучением и ударными волнами. В космическом пространстве радиоактивное излучение есть везде. Излучение приводит некоторый процент атомов в возбуждённое состояние, и считать их холодными уже нельзя. Поэтому могут идти реакции, имеющие очень большую энергию активации.

\section{4. Физико-химические свойства нефти и газа}

Поскольку нефть и её фракции состоят из большого числа разнообразных по химической природе веществ, различающихся количественно и качественно, физико-химические свойства нефтей представляют собой усреднённые характеристики, и показатели их непостоянны как для различных нефтей и фракций, так и для одинаковых фракций из разных нефтей.

\subsection{1. Физические свойства нефти}

Качественная характеристика и физические свойства нефтей зависят от преобладания в них отдельных углеводородов или их фракций.

Из физических параметров нефтей наибольшее значение имеют относительная плотность, вязкость, молекулярная масса, температуры кипения и застывания, теплота сгорания, электрические и оптические свойства [4-6].

Плотность нефти определяется как отношение массы вещества к занимаемому им объёму. Для нефти пользуются также относительной плотностью, которая численно равна отношению плотности нефти к плотности дистиллированной воды при 
температуре $4{ }^{\circ} \mathrm{C}$. Плотность нефтей в основном изменяется в

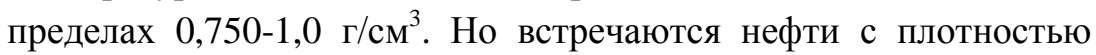
ниже 0,750 и густые асфальтообразные, плотность которых превышает 1,0. Различие в плотности нефтей связано с различием в количественном соотношении углеводородов отдельных классов: так, нефти с преобладанием алканов легче нефтей, богатых ароматическими углеводородами. Нефть, содержащая значительный процент смолистых соединений, характеризуется плотностью выше 1,0. Следует отметить, что плотность нефти уменьшается с повышением температуры и увеличением содержания в ней газа. Таким образом, газонасыщенная пластовая нефть всегда имеет меньшую плотность, чем дегазированная, и разница тем больше, чем больше извлечено газа.

Вязкость показывает свойство нефти оказывать при движении сопротивление перемещению частиц относительно друг друга. Вязкость имеет большое значение, т.к. она определяет масштабы миграции при формировании залежей нефти, играет важную роль при добыче нефти (вязкую нефть труднее извлечь из недр), определяет расход энергии на перекачку нефти по трубопроводам.

Различают динамическую, кинематическую и условную вязкость. Динамическая вязкость ( $\mu$ ) - это сопротивление, оказываемое жидкостью при перемещении со скоростью $1 \mathrm{~m} / \mathrm{c}$ относительно друг друга двух её слоев площадью $1 \mathrm{~m}^{2}$ каждый, находящихся на расстоянии 1 м, под действием приложенной силы в 1 Н. Единица измерения динамической вязкости Па•с. Величина, обратная динамической вязкости, называется текучестью.

Кинематическую вязкость можно определить через отношение динамической вязкости нефти к ее плотности, то есть при температуре определения. Кинематическая вязкость (v) имеет размерность $\mathrm{m}^{2} / \mathrm{c}$. 
Условная вязкость определяется как отношение времени истечения данной жидкости к истечению дистиллированной воды в одном и том же стандартном приборе при температуре $20^{\circ} \mathrm{C}$.

Вязкость нефтей зависит от их углеводородного состава, температуры и давления. С повышением температуры вязкость нефти уменьшается, а с повышением давления, наоборот, увеличивается. Высокомолекулярные углеводороды повышают значение вязкости, поэтому вязкость легких нефтей меньше, чем тяжелых. Наибольшей вязкостью обладают нафтеновые углеводороды. Вязкость пластовой нефти может быть существенно меньше вязкости дегазированной.

Вязкость имеет большое значение, т.к. она определяет масштабы миграции при формировании залежей нефти, играет важную роль при добыче нефти (вязкую нефть труднее извлечь из недр), определяет расход энергии на перекачку нефти по трубопроводам.

Средняя молекулярная масса большинства нефтей равна 250-300.

Температура кипения и застывания зависит от химического состава нефти. Диапазон температуры в среднем составляет 450-500 ${ }^{\circ} \mathrm{C}$.

Встречаются нефти с плюсовой температурой застывания, для которых характерно значительное содержание твёрдых парафинов. Беспарафинистые нефти, как правило, имеют отрицательные температуры застывания.

Теплота сгорания нефти составляет 43250-45500 Дж/кг (10400-11000 ккал/кг).

Электрические свойства нефтей в основном зависят от наличия в них воды и степени минерализации, так как чистые углеводороды являются диэлектриками, то есть обладают высоким удельным сопротивлением. 
Способность нефти накапливать электрический заряд предопределяет необходимость заземлять токопроводящие элементы оборудования.

Оптическими свойствами нефти являются люминесценция, флюоресценция, показатель преломления и цвет.

Люминесценция и флюоресценция имеют большое практическое значение в поиске и разведке нефти, позволяя обнаружить следы нефти в кернах и породах из отложений.

Наличие конденсированных многоядерных ароматических соединений в нефти вызывает заметная радужная окраска поверхности в отражённом свете (флюоресценция).

При облучении нефти ультрафиолетовыми лучами нефть люминесцирует, что обусловлено, главным образом, наличием в ней смол, асфальтенов, порфиринов.

Величина показателя преломления $(n)$ зависит от длины волны падающего света и температуры. Определяют его обычно на специальных приборах - рефрактометрах - при температуре $20{ }^{0} \mathrm{C}$ для монохроматического света (жёлтой линии $D$ натрия). Отсюда символ показателя преломления $\left(\mathrm{n}_{\mathrm{D}}{ }^{20}\right)$.

Цвет нефти может меняться от чёрного, тёмно-коричневого до красноватого, жёлтого и светло-жёлтого в зависимости от содержания серы и смолисто-асфальтеновых веществ.

\subsection{2. Фракционный состав нефти и продукты переработки нефти}

Важнейшим показателем нефти является ее фракционный состав (таблица 1.3).

Лабораторные исследования химического состава нефтей начинают с фракционной перегонки: отбирают узкие фракции, выкипающие в пределах двух-трёх, а иногда и одного градуса. В этих фракциях определяют содержание отдельных групп или индивидуальных углеводородов [4-6]. 
Таким образом, нефти и нефтепродукты разделяют путем перегонки на отдельные компоненты, представляющие собой менее сложные смеси, обычно называемые фракциями. Нефть и ее фракции характеризуются не температурой кипения, а температурными пределами - началом кипения и концом кипения.

В каждом конкретном случае наилучший вариант переработки выбирается на основе анализа физико-химических свойств узких 10-градусных фракций, отбираемых до $300{ }^{\circ} \mathrm{C}$, а затем 50градусных фракций, отбираемых до температуры конца кипения 475-550 ${ }^{\circ} \mathrm{C}$.

Из продуктов переработки нефти и их дальнейшей химической переработки путём смешения (компаундирования) в необходимом соотношении изготавливаются многочисленные и разнообразные нефтепродукты,

Таблий 1.3.

Фракционный состав нефти [6].

\begin{tabular}{|c|c|}
\hline Tемпературы кипения, ${ }^{\circ} \mathbf{C}$ & Фракция \\
\hline Менее 32 & $\begin{array}{c}\text { Легкие углеводородные газы до } \\
\text { бутана }\end{array}$ \\
\hline $32 \div 70$ & Газолин (петролейный эфир) \\
\hline $70 \div 120$ & Бензин \\
\hline $120 \div 180$ & Нафта (лигроин) \\
\hline $180 \div 240$ & Керосин \\
\hline $240 \div 350$ & Газойл \\
\hline 350 и выше & Мазут \\
\hline
\end{tabular}

Разделение мазута на фракции проводят в вакууме для понижения температуры кипения входящих в его состав компонентов и предупреждения их термического крекинга. При температуре $350-490{ }^{\circ} \mathrm{C}$ получается газойл, которая служит сырьем процесса каталитического крекинга. При этом получают в качестве целевого продукта высокооктановый компонент товарного бензина. Выше $500{ }^{\circ} \mathrm{C}$ получается гудрон, от которого окислением 
получают битум, а коксованием - кокс. Из мазута вакуумной перегонкой получают также масляные фракции различной вязкости: дистиллятных с пределами выкипания $300-400{ }^{\circ} \mathrm{C}, 350-420{ }^{\circ} \mathrm{C}$, $420-500{ }^{\circ} \mathrm{C}$ и остаточной $>500{ }^{\circ} \mathrm{C}$. После очистки и депарафинизации получают парафины и церезины.

Кроме того, из продуктов переработки нефти получают осветительный керосин, бензин (фр. 45-170 ${ }^{0} \mathrm{C}$ ), петролейный эфир (фр. $40-70{ }^{0} \mathrm{C}$ и 70-100 $\left.{ }^{0} \mathrm{C}\right)$ и уайт-спирит (фр. $\left.165-200{ }^{0} \mathrm{C}\right)$.

\subsection{3. Химическая и технологическая классификация нефтей}

Основную часть нефтей составляют углеводороды, различные по своему составу, строению и свойствам, которые могут находиться в газообразном, жидком и твердом состоянии. В состав нефти входит свыше четырехсот углеводородных соединений и более 60 микроэлементов, половина из которых - металлы. В зависимости от строения углеводородов они подразделяются на три класса - парафиновые, нафтеновые и ароматические. Но значительную часть нефти составляют углеводороды смешанного строения, содержащие структурные элементы всех трех упомянутых классов [4-6,152].

По количественному соотношению содержащихся в нефти различных групп углеводородов все нефти сгруппированы в четыре класса:

1) метановые, содержащие более $66 \%$ метановых углеводородов,

2) нафтеновые, содержащие более $66 \%$ нафтеновых углеводородов,

3) нафтено-метановые, в которых содержание метановых и нафтеновых углеводородов в сумме составляет более $66 \%$,

4) все нефти "необычного состава", т. е. ароматические и др. 
По содержанию парафина нефти подразделяются на три группы:

1) малопарафиновые - парафина до $1.5 \%$,

2) парафиновые - парафина от 1,5 до 6,0 \%,

3) высокопарафиновые - парафина свыше $6 \%$.

По содержанию серы нефти делятся на три группы:

1) малосернистые - серы до $0,5 \%$,

2) сернистые - серы от 0,5 до $2,0 \%$,

3) высокосернистые - серы более $2.0 \%$.

По содержанию смол выделяются три группы нефтей:

1) малосмолистые - смол менее $8 \%$,

2) смолистые - смол $8-28 \%$,

3) сильносмолистые - смол более $28 \%$.

По содержанию асфальтенов и смол выделяются 4 группы нефтей:

1) обычные нефти - 10-20\%,

2) тяжёлые нефти - 21-35\%,

3) мальты - 35-60 \%,

4) природные битумы - 60-98 \%.

По плотности нефти подразделены следующим образом:

1) легкие нефти с плотностью менее 0.8703 г/ $\mathrm{cm}^{3}$,

2) средние $-0.8703-0.9200 г / \mathrm{cm}^{3}$,

3) тяжелые $-0.9200-1.000 г / \mathrm{cm}^{3}$,

4) сверхтяжелые - более 1.0 г/ $\mathrm{cm}^{3}$ при вязкости менее 10000 мПа-с.

По количеству металлов нефти делятся на две группы:

1) обогащенные (> 10 г/т),

2) обедненные $(<1 \Gamma /$ т).

По соотношении $\mathrm{V}, \mathrm{Ni}$ и $\mathrm{Fe}$ выделяются три типи нефтей:

1) ванадиевые $(\mathrm{V}>\mathrm{Ni}>\mathrm{Fe})$,

2) никелевые $(\mathrm{Ni}>\mathrm{Fe}>\mathrm{V})$ или $(\mathrm{Fe}>\mathrm{Ni}>\mathrm{V})$,

3) железистые (Fe > V > Ni). 
По содержаниями ванадия и серы выделяется пять типов ванадиеносных нефтей:

1) I тип с $\mathrm{C}_{V} / \mathrm{C}_{S}=1,2 \cdot 10^{-3}$ и $\mathrm{C}_{\mathrm{S}}=2-6 \%$,

2) II тип с $\mathrm{C}_{\mathrm{V}} / \mathrm{C}_{\mathrm{S}}=(4-5) \cdot 10^{-3}$ и $\mathrm{C}_{\mathrm{S}}=2-5 \%$,

3) III тип с $\mathrm{C}_{V} / \mathrm{C}_{S}=(5-8) \cdot 10^{-3}$ и $\mathrm{C}_{\mathrm{S}}=(1,5-2) \%$,

4) IV тип с $\mathrm{C}_{V} / \mathrm{C}_{S}$ выше $8 \cdot 10^{-1}$ и $\mathrm{C}_{S}=2-5 \%$,

5) $\mathrm{V}$ тип с $\mathrm{C}_{\mathrm{V}}<40$ г/т и $\mathrm{C}_{\mathrm{S}}<1,3 \%$.

По вязкости (мПа.с при стандартных условиях) нефти подразделены следующим образом:

1) с незначительной вязкостью - менее 5;

2) маловязкие - 5-10;

3) с повышенной вязкостью - 10-30;

4) высоковязкие - более 30.

\section{5. Химический состав нефти}

\subsection{1. Алканы}

Парафиновые углеводороды, или алканы - алифатические углеводороды, в молекуле которых атомы углерода связаны между собой и с атомами водорода одинарной связью [4,5,153].

Общая формула парафинов $\mathrm{C}_{\mathrm{n}} \mathrm{H}_{2 \mathrm{n}+2}$. В зависимости от количества атомов углерода в молекуле углеводороды могут принимать одно из трех агрегатных состояний. Например, если в молекуле от одного до четырех атомов углерода $\left(\mathrm{CH}_{4}-\mathrm{C}_{4} \mathrm{H}_{10}\right)$, то углеводороды представляют собой газ, от 5 до $16\left(\mathrm{C}_{5} \mathrm{H}_{16}-\mathrm{C}_{16} \mathrm{H}_{34}\right)$ это жидкие углеводороды, а если больше $16\left(\mathrm{C}_{17} \mathrm{H}_{36}\right.$ и т.д.) твердые (табл. 2). Общее содержание алканов в нефтях составляет 40-50\% (об.), а в некоторых нефтях оно достигает 50-70\%. Однако есть нефти, в которых содержание алканов составляет всего 10-15\%. В основном нефть содержит двадцать-сорок индивидуальных нормальных и изомерных алканов, остальные присутствуют в незначительных количествах (физические свойства нормальных алканов приведены в таблице 1.4). Разветвлённые 
алканы довольно широко представлены в нефтях, однако среди них хорошо изучены лишь низкомолекулярные $\mathrm{C}_{4}-\mathrm{C}_{10}$. Из слаборазветвлённого строения алканов в нефти наиболее часто встречаются метилзамещённые. Для подавляющего большинства нефтей метанового и нафтено-метанового типа изомеры гексана по относительному их содержанию распределяются в следующий ряд:

гексан >2-метилпентан > 3-метилпентан >2,3-диметилбутан> 2,2-диметилбутан.

Среди гептанов указанных типов нефтей также преобладают нормальные изомеры. Однако, в отличие от гексановой фракции, в разветвлённых гептанах преобладает не 2-замещённый, а 3-замещённый изомер. Последовательность распределения изомеров гептана, в большинстве случаев, подчиняется следующему правилу:

Гептан > 3-метилгексан > 2-метилгексан > 2,3-диметилпентан >

3-этилпентан > 2,4-диметилпентан > 2,2-диметилпентан > 3,3-диметилпентан > 2,2,3 триметилбутан.

В распределении изомеров октана, нонана и декана существуют довольно устойчивые закономерности. Общим для них является уменьшение отношения суммы монозамещенных к сумме дизамещённых с ростом молекулярной массы. Из 18 изомеров октана обнаружено 17. Из 35 возможных изомеров нонана обнаружено 24.

Таблийа 1.4.

Физические свойства нормальных алканов.

\begin{tabular}{|c|c|c|c|c|}
\hline Название & $\begin{array}{c}\text { Химическая } \\
\text { формула }\end{array}$ & $\begin{array}{c}\text { Темпера- } \\
\text { тура кипе- } \\
\text { ния, }{ }^{0} \mathrm{C}\end{array}$ & $\begin{array}{c}\text { Температура } \\
\text { плавления, } \\
\mathrm{C}\end{array}$ & $\begin{array}{c}\text { Плотность } \\
\rho_{4}{ }^{20}\end{array}$ \\
\hline Метан & $\mathrm{CH}_{4}$ & $-161,6$ & $-182,5$ & 0,424 \\
\hline Этан & $\mathrm{C}_{2} \mathrm{H}_{6}$ & $-88,6$ & $-183,2$ & 0,546 \\
\hline Пропан & $\mathrm{C}_{3} \mathrm{H}_{8}$ & $-42,2$ & $-187,6$ & 0,585 \\
\hline
\end{tabular}




\begin{tabular}{|c|c|c|c|c|}
\hline Бутан & $\mathrm{C}_{4} \mathrm{H}_{10}$ & $-0,5$ & $-133,3$ & 0,579 \\
\hline 2-метилпропан & $\mathrm{C}_{4} \mathrm{H}_{10}$ & $-11,7$ & $-139,4$ & 0,563 \\
\hline Пентан & $\mathrm{C}_{5} \mathrm{H}_{12}$ & 36,1 & $-129,7$ & 0,626 \\
\hline 2-метилбутан & $\mathrm{C}_{5} \mathrm{H}_{12}$ & 27,9 & $-159,9$ & 0,620 \\
\hline $\begin{array}{c}2,2- \\
\text { диметилпропан }\end{array}$ & $\mathrm{C}_{5} \mathrm{H}_{12}$ & 9,5 & $-16,6$ & 0,613 \\
\hline Гексан & $\mathrm{C}_{6} \mathrm{H}_{14}$ & 68,8 & $-95,3$ & 0,659 \\
\hline 2-метилпентан & $\mathrm{C}_{6} \mathrm{H}_{14}$ & 60,0 & $-153,0$ & 0,653 \\
\hline 3-метилпентан & $\mathrm{C}_{6} \mathrm{H}_{14}$ & 63,3 & $-118,0$ & 0,664 \\
\hline $\begin{array}{c}2,3- \\
\text { диметилбутан }\end{array}$ & $\mathrm{C}_{6} \mathrm{H}_{14}$ & 58,0 & $-128,5$ & 0,661 \\
\hline $\begin{array}{c}2,2- \\
\text { диметилбутан }\end{array}$ & $\mathrm{C}_{6} \mathrm{H}_{14}$ & 49,7 & $-99,9$ & 0,649 \\
\hline Гептан & $\mathrm{C}_{7} \mathrm{H}_{16}$ & 98,4 & $-90,6$ & 0,684 \\
\hline 2-метилгексан & $\mathrm{C}_{7} \mathrm{H}_{16}$ & 90,1 & $-118,3$ & 0,679 \\
\hline 3-метилгексан & $\mathrm{C}_{7} \mathrm{H}_{16}$ & 91,9 & $-119,4$ & 0,687 \\
\hline 3-этилпентан & $\mathrm{C}_{7} \mathrm{H}_{16}$ & 93,5 & $-118,6$ & 0,698 \\
\hline $\begin{array}{c}2,2- \\
\text { диметилпентан }\end{array}$ & $\mathrm{C}_{7} \mathrm{H}_{16}$ & 79,2 & $-123,8$ & 0,674 \\
\hline $\begin{array}{c}2,3- \\
\text { диметилпентан }\end{array}$ & $\mathrm{C}_{7} \mathrm{H}_{16}$ & 89,8 & - & 0,695 \\
\hline $\begin{array}{c}2,4- \\
\text { диметилпентан }\end{array}$ & $\mathrm{C}_{7} \mathrm{H}_{16}$ & 80,5 & $-119,2$ & 0,673 \\
\hline $\begin{array}{c}\text { 3,3- } \\
\text { диметилпентан }\end{array}$ & $\mathrm{C}_{7} \mathrm{H}_{16}$ & 86,1 & $-134,5$ & 0,693 \\
\hline $\begin{array}{c}2,2,3- \\
\text { триметилбутан }\end{array}$ & $\mathrm{C}_{7} \mathrm{H}_{16}$ & 80,9 & $-24,9$ & 0,690 \\
\hline Октан & $\mathrm{C}_{8} \mathrm{H}_{18}$ & 125,7 & $-56,8$ & 0,703 \\
\hline Нонан & $\mathrm{C}_{9} \mathrm{H}_{20}$ & 149,5 & $-53,6$ & 0,718 \\
\hline Декан & $\mathrm{C}_{10} \mathrm{H}_{22}$ & 173,0 & $-30,3$ & 0,730 \\
\hline Ундекан & $\mathrm{C}_{11} \mathrm{H}_{24}$ & 195,8 & $-25,6$ & 0,740 \\
\hline Додекан & $\mathrm{C}_{12} \mathrm{H}_{26}$ & 214,5 & $-9,6$ & 0,745 \\
\hline Тридекан & $\mathrm{C}_{13} \mathrm{H}_{28}$ & 234,0 & $-6,0$ & 0,757 \\
\hline Тетрадекан & $\mathrm{C}_{14} \mathrm{H}_{30}$ & 252,5 & 5,5 & 0,764 \\
\hline Пентадекан & $\mathrm{C}_{15} \mathrm{H}_{32}$ & 270,5 & 10,0 & 0,769 \\
\hline Гексадекан & $\mathrm{C}_{16} \mathrm{H}_{34}$ & 287,0 & 18,1 & 0,775 \\
\hline Октадекан & $\mathrm{C}_{18} \mathrm{H}_{38}$ & 317,0 & 28,0 & 0,777 \\
\hline
\end{tabular}




\begin{tabular}{|c|c|c|c|c|}
\hline Эйкозан & $\mathrm{C}_{20} \mathrm{H}_{42}$ & 344,0 & 36,5 & 0,778 \\
\hline Пентакозан & $\mathrm{C}_{25} \mathrm{H}_{52}$ & 259/2кПа & 53,3 & - \\
\hline Триаконтан & $\mathrm{C}_{30} \mathrm{H}_{62}$ & 304/2 кПа & 65,9 & 0,780 \\
\hline $\begin{array}{c}\text { Пентатриа- } \\
\text { контан }\end{array}$ & $\mathrm{C}_{35} \mathrm{H}_{72}$ & 331/2 кПа & 74,6 & 0,781 \\
\hline Тетраконтан & $\mathrm{C}_{40} \mathrm{H}_{82}$ & - & 80,8 & - \\
\hline Пентаконтан & $\mathrm{C}_{50} \mathrm{H}_{102}$ & 421/2 кПа & 93,0 & - \\
\hline
\end{tabular}

В нефтях метанового типа преобладают нормальные алканы (до $50 \%$ ). В нефтях нафтенового типа содержатся преимущественно изоалканы (до $75 \%$ и более).

Так как нефти метанового типа относятся к старым нефтям, преобладание в них алканов нормального строения объясняют протеканием реакций отщепления боковых цепей у углеводородов изостроения. Преимущественное содержание изоалканов в нафтеновых нефтях свидетельствует, что они относятся к молодым, не претерпевшим ещё значительных превращений. В условиях пластового давления газообразные углеводороды растворены в нефти и в процессе её добычи выделяются вследствие снижения давления. Эти газы, которые сопровождают сырую нефть, называются попутными газами. Для этих газов характерно высокое содержание метана и наличие значительных количеств этана, пропана, бутанов и высших углеводородов вплоть до октана. Содержание жидких алканов в зависимости от месторождения нефти колеблется от 10 до $70 \%$. Во всех нефтях присутствуют твёрдые алканы. Для всех твёрдых алканов укрепилось техническое название «парафины». Парафинами называют углеводороды состава $\mathrm{C}_{17}-\mathrm{C}_{35}$. Парафинов в нефтях содержится 0,1-5\%. Однако встречаются высокопарафинистые нефти с содержанием 7-27\% твёрдых парафинов. Твёрдые углеводороды с числом углеродных атомов $\mathrm{C}_{36}-\mathrm{C}_{55}$ называются церезинами. $\mathrm{B}$ состав церезинов входят алканы нормального и изостроения, которые могут 
содержать в молекуле циклоалкановые и ароматические структуры. По внешнему виду похожи на воск.

Парафины имеют температуру плавления $27-71{ }^{\circ} \mathrm{C}$. Нефтяные церезины имеют более высокую относительную молекулярную массу, а температура плавления их 65 - $88{ }^{\circ} \mathrm{C}$. При одной и той же температуре плавления церезины по сравнению с парафинами имеют более высокую плотность и вязкость. Отличаются они также и по строению кристаллов. Парафины образуют пластинки и пластинчатые ленты, переплетающиеся между собой. Кристаллы легкоплавкого парафина имеют большие размеры, чем тугоплавкого. Церезины же кристаллизуются в виде мелких игл, плохо соединяющихся между собой, и поэтому они не образуют прочных застывающих систем, как парафины. Церезин и парафин обладают различными химическими свойствами.

В нефти были обнаружены углеводороды изопреноидного строения. Содержание изопреноидных углеводородов в нефтях колеблется в пределах 3-4 \% и выше. Название «изопреноидные углеводороды нефти» весьма условно, оно отнесено к алканам разветвлённого строения, являющимся гидрированными аналогами изопреноидов.

Они обладают полиизопреновым скелетом, с характерным чередованием метильных заместителей в цепи через три метиленовые группы. К алифатическим изопреноидным углеводородам, найденным в настоящее время в нефтях, можно отнести 2,6диметилалканы $\left(\mathrm{C}_{5}-\mathrm{C}_{13}\right), 3$,7-диметилалканы $\left(\mathrm{C}_{11}, \mathrm{C}_{12}, \mathrm{C}_{4}\right), 2,6,10$ триметилалканы $\left(\mathrm{C}_{14}-\mathrm{C}_{18}\right), 3,7,11$-триметилалканы $\left(\mathrm{C}_{16}\right), 2,6,10,14$ тетраметилалканы $\left(\mathrm{C}_{19}-\mathrm{C}_{25}\right)$.

В парафиновых нефтях преобладают фитан - 2,6,10,14-тетраметилгексадекан $\left(\mathrm{C}_{20} \mathrm{H}_{42}\right)$ и пристан -2,6,10,14-тетраметилпентадекан $\left(\mathrm{C}_{19} \mathrm{H}_{40}\right)$, а в нафтеновых 2,6,10-триметилундекан, 2,6,10триметилдодекан и 2,6,10-триметилтридекан. 


\subsection{2. Циклоалкань}

Общее содержание нафтенов в нефтях составляет 25 - 75\% (масс.).

Нафтены, или циклоалканы - углеводороды, содержащие в молекуле циклы, построенные из атомов углерода, связанные между собой $\sigma$-связью. Следовательно, молекулы нафтенов, не имеющие заместителей, состоят из связанных между собой и замкнутых в кольца метиленовых групп $\mathrm{CH}_{2}$. По сравнению с парафинами, нафтены имеют более высокую плотность и меньшую упругость паров и имеют лучшую растворяющую способность.

По числу циклов в молекуле циклоалканы подразделяются на моноциклические (общая формула $\mathrm{C}_{\mathrm{n}} \mathrm{H}_{2 n}$ ), бициклические (общая формула $\left.\mathrm{C}_{\mathrm{n}} \mathrm{H}_{2 \mathrm{n}-2}\right)$ и полициклические $\left(\mathrm{C}_{\mathrm{n}} \mathrm{H}_{2 \mathrm{n}-4}, \mathrm{C}_{\mathrm{n}} \mathrm{H}_{2 \mathrm{n}-6}\right.$ и т.д.) (три-, тетра-, пента- и гексациклические с короткими боковыми цепями -терпаны, стераны).

Общая формула моноциклических циклоалканов $\mathrm{C}_{\mathrm{n}} \mathrm{H}_{2 \mathrm{n}}$ При обычных условиях первые два члена $\mathrm{C}_{3} \mathrm{H}_{6}$ и $\mathrm{C}_{4} \mathrm{H}_{8}$ газы, $\left(\mathrm{C}_{5} \mathrm{H}_{10}-\right.$ $\mathrm{C}_{16} \mathrm{H}_{32}$ ) жидкости, начиная с $\mathrm{C}_{17} \mathrm{H}_{34}$ - твердые (физические свойства циклоалканов приведены в таблице 1.5).

Таблийа 1.5.

Физические свойства некоторых ичиклоалканов

\begin{tabular}{|l|c|c|c|}
\hline \multicolumn{1}{|c|}{ Название } & $\mathbf{T}_{\text {плавл }}{ }^{\mathbf{0}} \mathbf{C}$ & $\mathbf{T}_{\text {кип. }}{ }^{\mathbf{0}} \mathbf{C}$ & Плотность $^{\mathbf{P}^{20}}{ }_{\mathbf{4}}$ \\
\hline Циклопропан & -127 & -33 & 0.6884 \\
\hline Циклобутан & -80 & 13 & 0.7038 \\
\hline Метилциклопропан & -177 & 0.7 & 0,6912 \\
\hline Циклопентан & $-94,4$ & 49,3 & 0,7454 \\
\hline Этилциклопропан & -149 & 35 & 0,6770 \\
\hline Метилциклобутан & -149 & 37 & 0,6931 \\
\hline Этилциклобутан & -143 & 71 & 0,7450 \\
\hline Метилциклопентан & -143 & 72 & 0,7488 \\
\hline Этилциклопентан & $-138,4$ & 103,4 & 0,7657 \\
\hline
\end{tabular}




\begin{tabular}{|c|c|c|c|}
\hline 1,1-диметилциклопентан & $-69,7$ & 87,8 & 0,7523 \\
\hline $\begin{array}{l}\text { цис-1,2- } \\
\text { диметилциклопентан }\end{array}$ & $-53,8$ & 99,5 & 0,7723 \\
\hline $\begin{array}{l}\text { транс-1,2- } \\
\text { диметилциклопентан }\end{array}$ & $-117,6$ & 91,9 & 0,7519 \\
\hline Пропилциклопентан & $-120,3$ & 130,8 & 0,7756 \\
\hline Бутилциклопентан & $-108,2$ & 156,8 & 0,7843 \\
\hline Изопентилциклопентан & - & 169,0 & 0,4840 \\
\hline Циклогексан & 6,6 & 80,9 & 0,7781 \\
\hline Метилциклогексан & $-126,6$ & 100,8 & 0,7692 \\
\hline Этилциклогексан & $-114,4$ & 132,0 & 0,7772 \\
\hline 1,1-диметилциклогексан & $-33,5$ & 119,5 & 0,7840 \\
\hline $\begin{array}{l}\text { цис-1,2- } \\
\text { диметилциклогексан }\end{array}$ & $-50,1$ & 128,0 & 0,7965 \\
\hline $\begin{array}{l}\text { транс-1,2- } \\
\text { диметилциклогексан }\end{array}$ & $-89,4$ & 125,0 & 0,7760 \\
\hline Пропилциклогексан & $-94,5$ & 154,7 & 0,7932 \\
\hline Бутилциклогексан & $-78,6$ & 179,0 & 0,7997 \\
\hline Пентилциклогексан & - & 204,0 & 0,8040 \\
\hline Декалин & -40 & 186 & 0.8960 \\
\hline Адамантан & 270 & - & 1.0800 \\
\hline
\end{tabular}

Моноциклические циклоалканы являются преобладающими компонентами нефти. Они представлены преимущественно метилзамещёнными циклопентанами и циклогексанами. Преобладают соединения, замещённые в положении 1,3 и 1,2,3.

Циклогексановые гомологи более распространены, чем циклопентановые. В небольшом количестве в нефтях найдены алкилциклогептаны.

Из бициклических циклоалканов в нефтях найдены конденсированные декалин $\mathrm{C}_{10} \mathrm{H}_{18}$ (бицикло[4.4.0] деканан), пенталан (бицикло[3.3.0] окталан), гидриндан (бицикло[4.3.0] нонан), и мостиковый норборнан (бицикло[2.2.1] гептан), (бицикло[3.2.1] октан), (бицикло[3.3.1] нонан) и их гомологи. Наиболее широко распространены имеющие практическое значение декалины. 
Кроме конденсированных, бициклоалканы могут быть представлены в нефтях гомологами дициклопентила и циклогексила, циклопентилциклогексила и дициклогексилметана.

Из трициклических циклоалканов в нефтях обнаружен лишь адамантан $\mathrm{C}_{10} \mathrm{H}_{16}$ (трицикло[3.3.1.1] деканан) и его гомологи. Молекула адамантана очень устойчивая. Кристаллическая решётка у него такая же, как у алмаза.

Моноциклические циклоалканы с длинными боковыми цепями, а также циклоалканы сложной конденсированной структуры представляют собой при обычной температуре твёрдые вещества. Они являются компонентами парафинов и церезинов.

\subsection{3. Ароматические уалеводороды-арень}

Общее содержание аренов в нефтях составляет 10-20\% масс., а в ароматических нефтях их содержание доходит до $35 \%$. Наиболее богаты аренами молодые нефти.

Ароматические углеводороды - соединения, содержащие в молекуле особую циклическую группировку из шести атомов углерода, которая называется бензольной группировкой (бензольное ядро) $[4,5,153]$.

Различают одноядерные (одна бензольная группировка в молекуле) и полиядерные ароматические углеводороды, содержащие две или более бензольные группировки. В молекулах аренов в качестве боковых цепей могут находиться углеводородные радикалы с неразветвлённой или разветвлённой углеродной цепочкой, а также содержащие двойные или тройные связи и циклические группировки.

Общая формула моноциклических аренов $\mathrm{C}_{\mathrm{n}} \mathrm{H}_{2 \mathrm{n}-6}$, где п $\geq 6$. Арены являются ненасыщенными соединениями. В нефти присутствуют все метилзамещённые изомеры бензола до $\mathrm{C}_{10} \mathrm{H}_{14}$ включительно. Толуол, м-ксилол и 1,2,4 - триметилбензол представляют основные компоненты нефти. Среди дизамещённых 
гомологов бензола преобладают 1,3-, среди триалкилбензолов 1,3,5 и 1,2,4-изомеры (физические свойства аренов приведены в таблице 1.6).

Таблииа 1.6.

Физические свойства некоторых аренов.

\begin{tabular}{|c|c|c|c|}
\hline Название & $\mathbf{T}_{\text {плавл.". }},{ }^{0} \mathrm{C}$ & $\mathbf{T}_{\text {кип. }},{ }^{0} \mathrm{C}$ & Плотность, $\rho_{4}{ }^{20}$ \\
\hline Бензол & 5,5 & 80 & 0.8765 \\
\hline Толуол & -95 & 110 & 0.8669 \\
\hline Этилбензол & -94 & 136 & 0.8665 \\
\hline$o$-Ксилол & -25 & 144 & 0.8802 \\
\hline м-Ксилол & -47 & 139 & 0.8642 \\
\hline$n$-Ксилол & 13 & 138 & 0.8611 \\
\hline 1,2,4-триметилбензол & -44 & 169 & 0.8758 \\
\hline 1,3,5-триметилбензол & -45 & 165 & 0.8652 \\
\hline Пропилбензол & -99 & 159 & 0.8600 \\
\hline Изопропилбензол & -96 & 152 & 0.8620 \\
\hline трет-бутилбензол & -58 & 169 & 0,8669 \\
\hline н-бутилбензол & -89 & 183 & 0,8662 \\
\hline 1-Метил-2-пропилбензол & -60 & 185 & 0.8747 \\
\hline 1-Метил-3-пропилбензол & -61 & 182 & 0.8610 \\
\hline 1-Метил-4-пропилбензол & -62 & 183 & 0.8584 \\
\hline 1,2,3,4- тетраметилбензол & -6 & 205 & 0,9014 \\
\hline 1,2,3,5- тетраметилбензол & -24 & 193 & 0,8906 \\
\hline 1,2,4,5- тетраметилбензол & +79 & 197 & - \\
\hline н-амилбензол & -78 & 205 & 0,8618 \\
\hline Пентаметилбензол & -14 & 210 & 0,8830 \\
\hline Гексаметилбензол & +166 & 265,0 & - \\
\hline Стирол & -31 & 145 & 0.9090 \\
\hline Фенилацетилен & -45 & 142 & 0.9300 \\
\hline
\end{tabular}

Полиядерные ароматические углеводороды бывают несопряженными и сопряженными.

Углеводороды, в которых два или более бензольных кольца связаны простой связью, в соответствии с числом колец называют би-, тер - и т.д. фенилами, например: бифенил, п-терфенид. 
Ди- и полиарилалканы называются как арилзамещенные алканы: дифенилметан, дифенилэтан и их метилпроизводные, трифенилметан. арены, такие как нафталин (2), антрацен, фенантрен, флуорен(3), пирен, хризен, перилен(4) и их алкильные (главным образом, метильные) производные (физические свойства полиядерные ароматических углеводородов приведены в таблице 1.7).

Таблица 1.7.

Физические свойства некоторых полиядерные ароматических углеводородов.

\begin{tabular}{|c|c|c|c|}
\hline Название & $\mathbf{T}_{\text {плавл.", }}{ }^{\mathbf{0}} \mathbf{C}$ & $\mathrm{T}_{\text {кип., }}{ }^{\circ} \mathrm{C}$ & Плотность, $\rho_{4}{ }^{20}$ \\
\hline Нафталин & $+80,3$ & 218,0 & 1.1400 \\
\hline$\alpha$-метилнафталин & $+34,6$ & 241,1 & 1,029 \\
\hline 2,7-диметилнафталин & $+97,0$ & 262,3 & - \\
\hline$\beta$-этилнафталин & $-7,0$ & 258,0 & 0,9922 \\
\hline а-этилнафталин & $-13,8$ & 258,7 & 1,0081 \\
\hline Дифенил & 69 & 256 & 1.0400 \\
\hline Антрацен & 216 & 342 & 1.2500 \\
\hline Фенантрен & 199 & 340 & 1.1800 \\
\hline Флуорен & 116 & 295 & 1.2000 \\
\hline Пирен & 150,0 & 392,0 & 1,2770 \\
\hline Хризен & 254,0 & 448,0 & 1.2700 \\
\hline Перилен & 278 & 400 & - \\
\hline
\end{tabular}

Среднее содержание аренов, характерное для нефтей СНГ различных типов (в \% масс, в расчёте на арены): бензольные $67 \%$, нафталиновые - 18\%, фенантреновые - $8 \%$, хризеновые и бензофлуореновые - $3 \%$, пиреновые - $2 \%$, антраценовые $1 \%$, прочие арены - 1. Гомологи фенантрена присутствуют в значительно большем количестве, чем гомологи антрацена.

В нефти присутствуют также гибридные углеводородыполицикличекие углеводороды, молекулы которых содержат циклоалкановые структуры, конденсированные с аренами: индин, тетралин, флуорен, аценафтен. Ареновые циклы гибридных углеводородов имеют преимущественно короткие (метильные или 
этильные) заместители, циклоалкановые кольца - один или два довольно длинных алкильных заместителя.

\subsection{4. Непредельные углеводороды}

Непредельные, или ненасыщенные углеводороды - это углеводороды, в молекуле которых имеются углеводородные атомы, затрачивающие на связь с соседними атомами углерода более одной валентности - две или три.

Непредельные углеводороды называют ненасыщенными, так как они содержат меньшее число атомов водорода, чем предельные с тем же числом атомов углерода в молекуле.

Алкены - ненасыщенные соединения, содержащие двойную связь $\mathrm{C}=\mathrm{C}$. Раньше эти соединения называли олефинами. Общая формула алкенов $\mathrm{C}_{\mathrm{n}} \mathrm{H}_{2 \mathrm{n}}$. [4,5,153].

Ранее считалось, что непредельные углеводороды либо не содержатся в нефтях, либо содержатся в незначительных количествах. В конце прошлого века было показано, что в ряде нефтей Восточной Сибири, Татарии и других районов России содержание алкенов может доходить до 15-20\% от массы нефти. В небольших количествах они найдены и в канадской нефти. Из неё выделены углеводороды от $\mathrm{C}_{6} \mathrm{H}_{12}$ до $\mathrm{C}_{13} \mathrm{H}_{26}$ (физические свойства алуенов приведены в таблице 1.9). В небольших количествах непредельные углеводороды присутствуют в продуктах простой перегонки нефти.

Значительное количество непредельных углеводородов содержится в газах термической и каталитической переработки нефтяных фракций (до 25 \%). Большое количество газообразных алкенов содержится и в жидких продуктах крекинга - бензинах. Непредельные углеводороды являются важнейшим сырьём для нефтехимической промышленности. На их основе производят большую часть всех нефтехимических продуктов. 
Таблийа 1.9.

Физические свойства алкенов.

\begin{tabular}{|c|c|c|c|}
\hline Название & $\mathbf{T}_{\text {плавл, }},{ }^{0} \mathrm{C}$ & $\mathbf{T}_{\text {кип. }},{ }^{\circ} \mathbf{C}$ & Плотность,,$\rho_{4}{ }^{20}$ \\
\hline Этен & $-169,4$ & $-103,8$ & 0,570 \\
\hline Пропен & $-185,2$ & $-47,7$ & 0,610 \\
\hline Бутен-1 & $-185,4$ & $-6,3$ & $0,630^{-10}$ \\
\hline Цис-бутен-2 & $-139,3$ & 3,7 & $0,644^{-10}$ \\
\hline Транс-бутен-2 & $-105,8$ & 0,9 & 0,660 \\
\hline Изобутилен & $-140,8$ & $-6,9$ & 0,626 \\
\hline Пентен-1 & $-165,2$ & 30,1 & 0,611 \\
\hline Гексен-1 & $-139,8$ & 63,5 & 0,673 \\
\hline Бутадиен-1,3 & $-108,9$ & $-4,47$ & 0,640 \\
\hline 2-метилбутадиен-1,3 & $-146,0$ & 34,07 & 0,681 \\
\hline
\end{tabular}

\subsection{5. Гетеросоединения нефти}

Гетероорганические соединения, кроме углерода и водорода, содержат главным образом кислород, серу и азот. Они могут составлять $10-20 \%$ на сырую нефть. В состав нефти входит около 380 сложных гетеросоединений $[4,5,153]$. Большинство из указанных соединений относится к классу сернистых соединений.

\subsubsection{1. Соединения серы}

В настоящее время в нефтях обнаружено более 250 серосодержащих соединений $[4,5,153]$. В нефтях содержатся как неорганические, так и органические соединения серы: элементарная сера, сероводород, тиолы или меркаптаны, сульфиды, ди- и полисульфиды, тиофены. Из них основную долю составляют сульфиды и тиофены. Существуют и смешанные серо- и кислородсодержащие соединения - сульфоны, сульфоксиды и смешанные серо- и азотсодержащие соединения- тиазол и бензтиазол.

Элементарная сера содержится лишь в нефтях, связанных с известняковыми или сульфатно-доломитовыми отложениями. 
Количество элементарной серы может колебаться от 0,0001 до 0,1 \% масс. Она содержится в нефтях в растворённом состоянии. Количество растворённого в нефтях сероводорода может доходить до $0,02 \%$ масс.

Меркаптаны содержат тиольную (меркаптановую) группу SH. Общая формула тиолов: R-SH. Меркаптаны встречаются, главным образом, в бензиновых и керосиновых фракциях. Содержание меркаптанов в различных нефтях колеблется от 0 до $75 \%$ от всех содержащихся в них сернистых соединений. Из разных нефтей выделено более 50 меркаптанов с числом углеродных атомов от 1 до 8. Сюда относятся алкил-, циклоалкил- и арилмеркаптаны.

Общая формула сульфидов нефти R-S-R ${ }^{1}$. В нефтях найдено более 40 сульфидов, главным образом алкилсульфиды, в незначительных количествах обнаружены алкилциклоалкил-, алкилфенил- и дифенилсульфиды, алкилпроизводные тиопирана. Алкил-, циклоалкил- и арилсульфиды составляют 50-70 \%, алкилтофаны 40-50\% масс. от суммы сернистых соединений лёгких и средних фракций нефтей. В керосиновых и масляных фракциях содержатся полициклические сульфиды:

Дисульфиды - соединения общей формулы R-S-S-R ${ }^{1}$. Дисульфиды находятся в нефтях в небольших количествах. Дисульфиды - тяжёлые жидкости с неприятным запахом, почти нерастворимые в воде и легко растворимые в органических растворителях.

\subsubsection{2. Соединения азота}

Содержание азота в нефти редко превышает $1 \%$. Оно снижается с глубиной залегания нефти и мало зависит от характера вмещающих их пород. Азотистые соединения сосредоточены в высококипящих фракциях и особенно в тяжелых остатках-смолах $[4,5,153]$. Обычно азотсодержащие соединения нефти делят на 
две большие группы: азотистые основания и нейтральные азотистые соединения. Азотистые основания сравнительно легко выделяются минеральными кислотами и потому наиболее изучены. В настоящее время в нефти и его фракциях выделено более 50 индивидуальных азотистых оснований. Алкиламины в нефти не обнаружены. Амины основного характера представлены преимущественно третичными аминами -производными пиридина, хинолина, изохинолина, в меньшей степени акридина. Значительно реже представлены гомологи анилина. Нейтральные азотсодержащие соединения нефти представлены арилпроизводными пиррола, индола, карбазола, бензокарбазола и амидами кислот. Убедительных доказательств наличия в нефти самого пиррола и простейших его алкилзамещенных пока нет.

Интересным типом азотсодержащих соединений являются нефтяные порфирины, довольно подробно изученные в настоящее время.

\subsubsection{3. Соединения кислорода}

Кислород в нефтях встречается в связанном состоянии в составе нафтеновых кислот (около 6\%), фенолов (не более 1\%), а также жирных кислот,кетонов и эфиров, а также вместе с азотом и серой в асфальтово- смолистых компонентах [4,5,142].

Основная часть кислородных соединений нефтей имеет характер карбоновых кислот, общей формулы $\mathrm{C}_{\mathrm{n}} \mathrm{H}_{\mathrm{m}} \mathrm{COOH}$. Впервые кислородные соединения были обнаружены в Бакинском керосине. Было установлено, что кислоты с числом углеродных атомов в молекуле от 8 до 11 содержат циклопентановое кольцо. Исследования показали, что карбоксильная группа не связана непосредственно с пятичленным кольцом, а отделена от него одной или несколькими метиленовыми группами и, следовательно, входит в одну из боковых цепей. Из Румынской и Западно-Украинской нефтей выделили кислоты $\mathrm{C}_{8}-\mathrm{C}_{11}$, как с пятичленным, так и 
шестичленным нафтеновым кольцом. Поскольку эти кислоты оказались производными моноциклических нафтенов с общей формулой $\mathrm{C}_{\mathrm{n}} \mathrm{H}_{2 \mathrm{n}-1} \mathrm{COOH}$, то они получили название нафтеновых кислот. Нафтеновые и высшие кислоты найдены во всех нефтях, но в незначительных количествах (от сотых долей до $3 \%$ ).

Исходя из этого, в последнее время все чаще кислоты, выделенные из нефти, стали называть не нафтеновыми, а нефтяными. Наиболее изученный класс кислородсодержащих соединений нефти - нефтяные кислоты. В бензиновых фракциях встречаются только алифатические кислоты, так как температура кипения простейших алициклических и ароматических кислот выше $200^{\circ} \mathrm{C}$. Эти кислоты имеют преимущественно нормальное или слаборазветвленное строение (с одним метильным заместителем в боковой цепи). Алифатические кислоты обнаружены также и в высококипящих фракциях. В настоящее время из нефтей выделены все кислоты нормального строения, содержащие до 25 атомов углерода в цепи. По мере повышения температуры кипения нефтяных фракций в них появляются алифатические кислоты разветвленной структуры, содержащие два и более метильных заместителя в основной цепи. Наиболее интересной группой полиметилзамещённых алифатических кислот являются кислоты изопреноидной структуры. В настоящее время выделены 2,6,10-триметилундекановая, 3,7,11-триметилдодекановая, 2,6,10, 14-тетраметилпентадекановая (пристановая) и 3,7,11,15-тетраметилгексадекановая (фитановая) кислоты.

Нефтяные фенолы, несмотря на значительное содержание их в нефти, изучены недостаточно. Наиболее известны низшие фенолы $\left(\mathrm{C}_{6}-\mathrm{C}_{9}\right)$. Например, в Западно-Сибирских нефтях наблюдается следующая закономерность в распределении фенолов, крезолов и ксиленолов: концентрация фенолов возрастает в ряду

$$
\mathrm{C}_{6}<\mathrm{C}_{7}<\mathrm{C}_{8}<\mathrm{C}_{9} .
$$


Среди крезолов преобладают орто-изомер, а у ксиленолов 2,4- и 2,5-диметилфенолы.

Из бензиновой фракции Калифорнийской нефти выделено 6 индивидуальных кетонов: ацетон, метилэтил-, метилпропил-, метилизопропил-, метилбутил- и этилизопропилкетоны. В некоторых нефтях кетоны составляют основную часть алифатических нейтральных кислородсодержащих соединений. В средних и высококипящих фракциях нефтей обнаружены циклические кетоны типа ацетилизопропилметилциклопентана и флуоренона. К нейтральным кислородсодержащим соединениям нефти относятся также сложные и простые эфиры. Большинство сложных эфиров содержатся в высококипящих фракциях или нефтяных остатках. Многие из них являются ароматическими соединениями, иногда представленными внутренними эфирами - лактонами.

В высококонцентрированном виде смолисто - асфальтовые вещества находятся в природе в виде природных битумов. Соотношение между смолами и асфальтенами в нефтях составляет от 9:1 до 7:1. Смолы представляют собой очень вязкие малоподвижные жидкости, а иногда и твёрдые аморфные вещества от тёмнокоричневого до бурого цвета. Смолистые вещества заключают около 93\% кислорода в нефтях. Содержание углерода в смолях колеблется в пределах 79-87 \%, а водорода в нефтях 9-11\%. Содержание серы в отдельных смолах достигает 7-10 \%. Содержание кислорода достигает 1-7 \%, а азота не превышает $2 \%$. Плотность смол близка к 1,1 кг/л, молекулярная масса от 600 до 1000 , реже до 2000.

Асфальтены представляют собой черное твердое аморфное вещество. Они являются более высокомолекулярными соединениями, чем смолы. Среднестатистическое содержание асфальтенов в нефтях составляет $2 \%$, достигая $5 \%$ и более в их тяжелых разновидностях.

Асфальтены отличаются от смол не только несколько меньшим содержанием водорода(1-2 \%), но и большим содержанием железа, ванадия, никеля и др. Плотность асфальтенов выше 1,14 
кг/л, молекулярная масса от 1000 до 5000, в основном до 11000. Предполагают, что асфальтены являются продуктами конденсации смол. Если смолы растворяются в жидких углеводородах всех групп, то асфальтены нерастворимы в метановых углеводородах, частично растворимы в нафтеновых и лучше растворяются в ароматических. В «белых» нефтях смолы содержатся в малых количествах, а асфальтены вообще отсутствуют.

\subsection{6.Металлы в нефти}

В составе нефти обнаружено более 60 микроэлементов, половина из них - металлы [3]. Средние концентрации микроэлементов в нефтях уменьшаются в следующем ряду: $\mathrm{Cl}, \mathrm{V}, \mathrm{Fe}, \mathrm{Ca}, \mathrm{Ni}$, $\mathrm{Na}, \mathrm{K}, \mathrm{Mg}$, Si, Al, I, Br, Hg, Zn, P, Mo, Cr, Sr, Cu, Rb, Co, Mn, Ba, $\mathrm{Se}, \mathrm{As}, \mathrm{Ga}, \mathrm{Cs}, \mathrm{Ge}, \mathrm{Ag}, \mathrm{Sb}, \mathrm{U}, \mathrm{Hf}, \mathrm{Eu}, \mathrm{Re}, \mathrm{La}, \mathrm{Sc}, \mathrm{Pb}, \mathrm{Au}, \mathrm{Be}, \mathrm{Ti}, \mathrm{Sn}$.

B природных нефтях и твердых битумах металлы находятся в следующих формах: $\mathrm{Cu}, \mathrm{Fe}, \mathrm{Pb}$ и $\mathrm{U}$ образуют истинные растворы; $\mathrm{Zn}, \mathrm{Cu}, \mathrm{Ni}, \mathrm{U}, \mathrm{Ca}, \mathrm{Mg}, \mathrm{Fe}$ и V образуют коллоидные растворы, адсорбированные на активной поверхности нефть/вода; $\mathrm{Cu}$, $\mathrm{Zn}, \mathrm{Ge}, \mathrm{Au}$ находятся в составе полярных смол в виде солей органических кислот; $\mathrm{Hg}, \mathrm{Sb}, \mathrm{As}, \mathrm{V}, \mathrm{Ni}, \mathrm{Fe}, \mathrm{Cu}, \mathrm{Co}, \mathrm{Cr}$ образуют металлоорганические соединения, a V и Ni образуют металлопорфириновые комплексы $[41,42]$. Установлено, что концентрация большинства микроэлементов возрастает с увеличением молекулярной массы и ароматичности асфальтенов, а фракции асфальтенов, обогащенные микроэлементами,всегда имеют повышенное содержание азота, серы и кислорода[4,5]. Предполагают, что атомы металлов создают комплексные соединения с гетероатомами асфальтенов по донорно-акцепторному типу.

О наличии металлов в нефти обсуждалось в подглавах 1.3 .3 и 1.4.3, поэтому ниже приведени новые данные.

Если содержание ванадия превышает содержание никеля в нефти (V/Ni >1), то нефтегазоносный бассейн относится к ванадиевому типу, если содержание ванадия меньше содержания ни- 
келя в нефти $(\mathrm{V} / \mathrm{Ni}<1)$, то нефтегазоносный бассейн относится к никелевому типу. Нефтегазоносными бассейнами России и прилегающих территорий с доминированием никелевых соединений являются Анадырско-Наваринский $(\mathrm{V} / \mathrm{Ni}=0,67)$, Пенжинский $(\mathrm{V} / \mathrm{Ni}=0,23)$ и Тимано-Печорский $(\mathrm{V} / \mathrm{Ni}=0,48)$. Для нефтегазоносных бассейнов Балтийский $(\mathrm{V} / \mathrm{Ni}=2,37)$, Волго-Уральский $(\mathrm{V} / \mathrm{Ni}=2,96)$, Западно-Сибирский $(\mathrm{V} / \mathrm{Ni}=1,50)$, Лено-Тунгусский $(\mathrm{V} / \mathrm{Ni}=2,66)$, Охотский $(\mathrm{V} / \mathrm{Ni}=2,59)$, Прикаспийский $(\mathrm{V} / \mathrm{Ni}=1,27)$ и Северо-Кавказский $(\mathrm{V} / \mathrm{Ni}=1,19)$ характерны высокие концентрации ванадия, а бассейны относятся к ванадиевому типу [154,155].

Ванадий присутствует почти во всех месторождениях нефти России и Западного Казахстана.

На золоторудном проявлении Пионерское Дегдеканского рудного поля Центральной Колымы, в зоне битуминизации осадочных пород отмечается увеличение концентрации золота на порядок и более по сравнению с кларковыми содержаниями. Содержание золота в битуме составило в среднем 520 г/т [156,157], что значительно превышает содержание этого металла во многих коренных его месторождениях $[85,86]$. Золото в количестве до 2 г/т на одну из фракций обнаружено в гидротермальных битумах в древних вулканических трубках Сибири. Надо думать, что указанный механизм массопереноса является причиной того, что в нефтяных залежах находят такие компоненты, как ртуть, редкоземельные элементы, золото, серебро, многие другие компоненты руд. Появление этих веществ в нефтяных залежах- лишь отдельное звено в рассматриваемом процессе, они проникают в качестве дополнительных, более глубинных компонентов. Позднее о тесной связи нефти и ртути сообщила Н.А. Озерова [158]. Выделены ртуторудные пояса нового типа - по $\mathrm{Hg}$-содержащим месторождениям различного вещественного состава (рудногазонефтяным), которые приурочены к линеаментным структурам планетарного масштаба [87]. Выделение этой структуры как ртутоносной оказалось весьма плодотворным и позволило спрогнозировать повышенную ртутоносность в ряде газовых место- 
рождений. Наиболее перспективны в этом плане месторождения, приуроченные к проницаемым участкам земной коры - узлам пересечения активизированных продольных и поперечных зон разломов мантийного заложения. Впервые такой прогноз был осуществлен для газоконденсатных месторождений Опошня в Днепрово-Донецкой впадине, а позднее для Астраханского, Оренбургского и Карачаганакского месторождений в Прикаспийской впадине. Содержания ртути в газах всех трех месторождений весьма близки; они на 2-3 порядка выше, чем в атмосферном воздухе. Но основным концентратором ртути в газоконденсатной смеси является углеводородный конденсат; общая валовая концентрация ртути существенно зависит от содержания конденсата. Рассчитанные концентрации ртути в газоконденсатной смеси в поверхностных условиях таковы: 9,9 $910^{-5} \mathrm{r} / \mathrm{M}^{3}$ на Астраханском месторождении, $4,4 \times 10^{-5} \Gamma^{2} \mathrm{M}^{3}$ на Карачаганакском месторождении и $6 \times 10^{-6} \Gamma / \mathrm{M}^{3}$ на Оренбургском месторождении. Но это не истинные концентрации ртути в пластовой смеси, где газ находится под давлением. Рассчитанные концентрации ртути в пласте соответственно равны $3,9 \cdot 10^{-2}, 1,5 \cdot 10^{-2}$ и $1,1 \cdot 10^{-3}$ г/м ${ }^{3}$; это уже высокие содержания.

Нефти содержат также другие металлы- $\mathrm{Mo}, \mathrm{Pb}, \mathrm{Ag}, \mathrm{Zn}, \mathrm{Cr}$ и тд.

Молибден в нефтях содержится в количестве нескольких г/т. Например, содержание молибдена в твердых битумах и тяжелых нефтях Атабаски, Колд-Лейк и Ллойдминстер составляет соответственно 10, 7.3 и 3.3 г/т. Среднее содержание молибдена в Венесуэльской нефти составляет 60 г/т.

Олово обнаружено менее чем в половине нефтей на западе США. Серебро присутствует в зольных остатках нефтей на западе США менее 1 г/т). Среднее содержание в нефтях Алберти цезия, рубидия и европия составляет соответственно 4,3, 0,015 и 0,94 г/т. В ряде нефтеносных районов-Челекен и Галф-Кост, в пробуренных на нефть скважинах образуются пробки из самородного свинца и цинка или их сульфидов. 


\section{ГЛАВА 2 \\ РОЛЬ C-H-O-S-N-V-Ni CИСТЕМЫ В ГЕНЕЗИСЕ АБИОГЕННОЙ НЕФТИ}

\section{1. Роль С-Н-О системы в генезисе нефти}

В Солнечной системе водород, углерод и кислород находятся вместе с гелием и азотом в первой пятерке. Среднее содержание углерода, водорода и кислорода в земной коре, по К.Г. Ведополю, составляет соответственно 0.7 кг/т, 0.3 кг/т и 472.5 кг/т [169]. По оценке Д.Н. Тимофеева потенциальные запасы углеводородов нашей планеты составляют $1.9 \times 10^{18}$ тонн [33,34]. О роли С-Н и СН-О систем в генезисе нефти, в некотором аспекте, уже обсуждалось в главе 1 (1.2.) [19-22]. Основными компонентами синтеза УВ в мантии и астеносфере являются карбиды металлов, углерод, $\mathrm{CO}, \mathrm{CO}_{2}, \mathrm{H}_{2}$ и $\mathrm{H}_{2} \mathrm{O}$.

\subsection{1. Процесс Фишера-Тропша и другие в генезисе нефти}

Возможность синтеза УВ из окисленных форм углерода (СО и $\mathrm{CO}_{2}$ ) с участием воды и водорода давно установлена $[160,161]$. Эти процессы могут происходить вследствие многих экзотермических каталитических реакций с участием катализаторов оксидов металлов (Fe, Ni и др.).

Важную роль из этих реакций играет синтез ФишераТропша:

$$
\begin{gathered}
\mathrm{nCO}+(2 \mathrm{n}+1) \mathrm{H}_{2} \rightarrow \mathrm{C}_{\mathrm{n}} \mathrm{H}_{2 \mathrm{n}+2}+\mathrm{nH}_{2} \mathrm{O} \\
\mathrm{nCO}+2 \mathrm{nH}_{2} \rightarrow \mathrm{C}_{\mathrm{n}} \mathrm{H}_{2 \mathrm{n}}+\mathrm{nH}_{2} \mathrm{O} .
\end{gathered}
$$

Так, немецкие химики Ф. Фишер и Х. Тропш в 1923 г. сообщили о получении кислородсодержащих продуктов из синтез- 
газа (смесь $\mathrm{CO}$ и $\mathrm{H}_{2}$ ) над Fе катализаторами, а в 1926 г. - УВ. На основе технологии Фишера-Тропша (Со-Тh осаждённый катализатор) в Германии в 1935 г., было налажено производство синтетического бензина. Сырьём для процесса служил уголь, из которого газификацией получали синтез-газ, а из него - углеводороды [160].

В работе [161] показано, что при изменении температуры и давления распределение получающихся УВ меняется. При низких термобарических условиях выход легких алканов увеличивается. Баренбаум А.А. формирование месторождений нефти и газа рассматривает совместно с процессом климатического круговорота воды [162].

Побочными реакциями синтеза углеводородов из $\mathrm{CO}$ и $\mathrm{H}_{2}$ являются:

$$
\begin{gathered}
\mathrm{CO}+3 \mathrm{H}_{2} \rightarrow \mathrm{CH}_{4}+\mathrm{H}_{2} \mathrm{O}, \\
2 \mathrm{CO} \rightarrow \mathrm{CO}_{2}+\mathrm{C} \text { (реакция Белла-Будуара) } \\
\mathrm{CO}+\mathrm{H}_{2} \mathrm{O} \rightarrow \mathrm{CO}_{2}+\mathrm{H}_{2}, \\
(3 \mathrm{n}+1) \mathrm{CO}+(\mathrm{n}+1) \mathrm{H}_{2} \mathrm{O} \rightarrow \mathrm{C}_{\mathrm{n}} \mathrm{H}_{2 \mathrm{n}+2}+(2 \mathrm{n}+1) \mathrm{CO}_{2}
\end{gathered}
$$

(синтез Кёльбеля-Энгельгарда).

По ацетиленовой теории Бертло, из ацетилена получался бензол.

$$
\begin{gathered}
2 \mathrm{C}+\mathrm{H}_{2} \rightarrow \mathrm{C}_{2} \mathrm{H}_{2}, \\
\mathrm{CaC}_{2}+2 \mathrm{H}_{2} \mathrm{O} \rightarrow \mathrm{Ca}(\mathrm{OH})_{2}+\mathrm{C}_{2} \mathrm{H}_{2}, \\
3 \mathrm{C}_{2} \mathrm{H}_{2} \rightarrow \mathrm{C}_{6} \mathrm{H}_{6}
\end{gathered}
$$

\subsection{2. Роль воды в генезисе нефти}

Вода - химическое соединение кислорода и водорода, которое принято обозначать формулой $\mathrm{H}_{2} \mathrm{O}$. Она играет фундаментальную роль во многих процессах и явлениях, происходящих в Земле, на Земле и вокруг Земли. До сих пор не раскрыты все «тайны» воды, хотя более или менее изучены ее свойства, пове- 
дение в различных условиях и многое о воде уже известно. Химическая природа ее до сих пор окончательно не установлена, и на самом деле вода имеет более сложный состав.

Молекулярная масса воды равна 18, но встречаются молекулы с молекулярной массой 19, 20, 21 и 22. Они состоят из более тяжелых атомов водорода и кислорода, имеющих атомную массу соответственно более 1 и 16. Природные воды имеют неодинаковый изотопный состав. Из известных разновидностей молекул воды стабильны девять [163-165].

Молекула воды имеет угловое строение: представляет собой равнобедренный треугольник с углом при вершине $104,5^{\circ}$. Атом кислорода находится в $\mathrm{sp}^{3}$ - гибридном состоянии; из четырех гибридных орбиталей кислорода две участвуют в образовании одинарных связей $\mathrm{O}-\mathrm{H}$, а две другие $\mathrm{sp}^{3}$ - гибридные орбитали заняты неподеленными электронными парами, их действие является причиной уменьшения угла от $109,28^{\circ}$ до $104,5^{\circ}$. Молекула воды представляет собой диполь, содержащий положительный и отрицательный заряды на полюсах. Около ядра кислорода, наблюдается избыток электронной плотности, а на противоположной стороне молекулы около ядер водорода имеется недостаток электронной плотности.

Именно такая структура и определяет полярность молекулы воды.

Вследствие полярности молекула воды способна притягивать другие молекулы, образуя гидраты. Многие химические реакции могут протекать только в присутствии воды. Таким образом, вода является растворителем, реагентом и катализатором. Кроме того, вода выполняет транспортную функцию. 


\subsubsection{1. Представление об аномальных и специфических свойствах воды}

Аномальные свойства воды свидетельствуют о том, что молекулы воды довольно прочно связаны между собой и образуют характерную молекулярную конструкцию, которая сопротивляется тепловым, механическим и электрическим разрушающим воздействиям. Согласно современным представлениям, наличие водородных связей между молекулами воды приводит к возникновению так называемых водных кластеров, или комплексов. Однако необычные свойства воды связаны не только с наличием водородной связи, но и также обстоятельством, что структура жидкой воды проявляет свойства, как целостная система [166-170].

Ниже представляем аномальные свойства воды [164-165, 168-178].

1. Теплоемкость - наиболее высокая, за исключением $\mathrm{NH}_{3}$ (при $20^{\circ} \mathrm{C} 4731$ Дж/(кг·град). При атмосферном давлении и температуре до $100^{\circ} \mathrm{C}$ она находится в виде жидкости и ее теплоемкость изменяется в диапазоне от 4174 до 4220 Дж/(кг·град). Зависимость теплоемкости воды от температуры при атмосферном давлении не линейна. При нагревании воды до $27^{\circ} \mathrm{C}$ теплоемкость уменьшается от 4217 до 4174 Дж/(кг·град), затем в интервале температуры $27-40{ }^{\circ} \mathrm{C}$ значение этой величины остается практически постоянным (следует отметить, что в этом диапазоне температуры вода обладает наименьшей теплоемкостью). При температуре выше $40^{\circ} \mathrm{C}$ ее удельная теплоемкость увеличивается и достигает своего максимума при температуре кипения 4220 Дж/(кг:град).

2. Температура кипения и замерзания воды. Если бы вода была бы нормальным мономолекулярным соединением, таким, например, как гидриды ее аналогов: серы, селена и телура по шестой группе периодической системы элементов Д.И. Менде- 
леева, то в жидком состоянии вода существовала бы в диапазоне от минус $100{ }^{\circ} \mathrm{C}$ до минус $80{ }^{\circ} \mathrm{C}$ (см. таблицу 2.1).

Таблица 2.1.

Температура кипения и замерзания воды и ее химических аналогов.

\begin{tabular}{|c|c|c|c|c|}
\hline Соединение & $\mathbf{H}_{\mathbf{2}} \mathbf{O}$ & $\mathbf{H}_{2} \mathbf{S}$ & $\mathbf{H}_{2} \mathbf{S e}$ & $\mathbf{H}_{\mathbf{2}} \mathbf{T e}$ \\
\hline $\mathrm{M}, \Gamma /$ моль & 18 & 34 & 80 & 129 \\
\hline$<\mathrm{HЭН}$ & 104,6 & 92 & 90 & 90 \\
\hline $\mathrm{T}_{\text {зам., }}{ }^{\circ} \mathrm{C}$ & 0 & -82 & -64 & -51 \\
\hline $\mathrm{T}_{\text {кип., }}{ }^{\circ} \mathrm{C}$ & 100 & -61 & -42 & -4 \\
\hline
\end{tabular}

3. Летучесть воды наименьшая, тогда как у соединений водорода с элементами подгруппы кислорода она возрастает при переходе от телура к сере (см. таблицу 2.1).

4. Плотность воды в зависимости от температуры максимальная при температуре от 3,8 до $4,2{ }^{\circ} \mathrm{C}$. В этих условиях точное значение плотности воды составляет величину 999,972 кг/м³. Такая температурная зависимость плотности характерна только для воды. Вода существует как отдельная жидкость при температуре от 0 до $374,12{ }^{\circ} \mathrm{C}$ - это ее критическая температура, при которой исчезает граница раздела между жидкостью и водяным паром. Температура замерзающей воды подо льдом равна $0{ }^{\circ} \mathrm{C}$. В более плотных слоях воды у дна водоема температура оказывается порядка $4{ }^{\circ} \mathrm{C}$. Благодаря этому жизнь может существовать в воде замерзающих водоемов.

5. Сжимаемость, то есть степени уменьшения объема при увеличении давления. Обычно сжимаемость жидкости растет с температурой: при высоких температурах жидкости более рыхлы (имеют меньшую плотность) и их легче сжать. При нагреве воды от точки плавления вплоть до $46^{\circ} \mathrm{C}$ сжимаемость уменьшается, а потом увеличивается.

6. Удельная теплота плавления льда наиболее высокая (330кДж/кг), за исключением $\mathrm{NH}_{3}-332,3$ кДж/кг. 
7. Удельная теплота испарения - наиболее высокая из всех веществ. При нормальном атмосферном давлении удельная теплота парообразования воды равна 2258 кДж/кг, а температура кипения воды составляет $100{ }^{\circ} \mathrm{C}$. При увеличении давления, например до 100 атм., величина теплоты парообразования воды снижается до 1315 кДж/кг.

8.Тепловое расширение - температура, соответствующая максимальной плотности, уменьшается с повышением соленности. Коэффициент $\beta$ называют температурным коэффициентом объемного расширения. Этот коэффициент у жидкостей в десятки раз больше, чем у твердых тел. У воды, например, при температуре $20{ }^{\circ} \mathrm{C} \beta_{\mathrm{B}} \approx 2 \cdot 10^{-4} \mathrm{~K}^{-1}$. Тепловое расширение воды имеет интересную и важную для жизни на Земле аномалию. При температуре ниже $4{ }^{\circ} \mathrm{C}$ вода расширяется при понижении температуры $(\beta<0)$. Максимум плотности $\rho_{\text {в }}=10^{3}$ кг $/ \mathrm{M}^{3}$ вода имеет при температуре $4{ }^{\circ} \mathrm{C}$.

9. Поверхностное натяжение-наиболее высокое из всех жидкостей, кроме ртути. У воды коэффициент поверхностного натяжения при температуре $20{ }^{\circ} \mathrm{C}$ на воздухе равен $72.86 \mathrm{MH} / \mathrm{M}$.

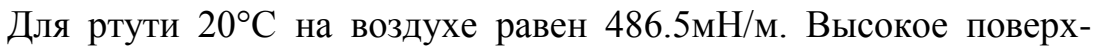
ностное натяжение позволяет воде иметь шарообразную форму при свободном падении. Поверхностное натяжение и смачивание являются основой особого свойств воды и водных растворов, названного капиллярностью. В микроканалах вода приобретает удивительные свойства. Она становится более вязкой, уплотняется в полтора раза, а замерзает при $-75{ }^{\circ} \mathrm{C}$. Связанная межмолекулярными силами с поверхностью пор и микрополостей пород и минералов земной коры и других объектов живой и неживой природы. Эта поровая вода, обладает особой структурой.

10. Относительная диэлектрическая проницаемость - наиболее высокая из всех жидкостей (для чистой воды $\varepsilon=81$ при $\left.20{ }^{\circ} \mathrm{C}\right)$, за исключением формамида $\left(\varepsilon=84\right.$ при $\left.20{ }^{\circ} \mathrm{C}\right)$. Большое значение диэлектрической проницаемости объясняется особен- 
ностями молекулы $\mathrm{H}_{2} \mathrm{O}$. Это связано с тем, что вода - сильно полярная жидкость и поэтому обладает мягкой ориентационной степенью свободы (т.е. вращения молекулярных диполей).

11. Растворяющая способность - как правило, растворяет большинство веществ. Эксперименты показали, что вода и водные растворы после прогрева при высоких значениях температуры и давления в течение некоторого времени находятся в метастабильном состоянии.

Метастабильная вода характеризуется повышенной растворяющей способностью по отношению к карбонатам, сульфатам, оксидам и силикатам; она имеет пониженные значения $\mathrm{pH}$ и длительное время удерживает в своем составе аномальные количества растворенного вещества. Так, вода, активированная при 200, 300 и $400{ }^{\circ} \mathrm{C}$, повышает свою растворяющую способность по отношению к кальциту в 2, 3 и 4 раза соответственно [9]. Способность воды сохранять свое структурное состояние в течение некоторого времени после изменения внешних условий называется структурной памятью воды [16].

12. Электролитическая диссоциация - очень мала. Вода, это нейтральное вещество, хотя содержит ионы $\mathrm{H}^{+}$и $\mathrm{HO}^{-}$.

13. Теплопроводность - наиболее высокая из всех жидкостей. При $35{ }^{\circ} \mathrm{C}$ вода имеет наименьшую теплопроводимость. Основную роль играет в процессах, которые происходят в живых клетках, но для молекулярных процессов оказывается гораздо важнее, чем вихревая проводимость

14. Вязкость- при температуре ниже $35{ }^{\circ} \mathrm{C}$ с увеличением давления от атмосферного до 0,2 ГПа вязкость воды уменьшается, проходит через минимум и только потом возрастает. Определяет гидродинамику водных объектов и седиментацию взвешенных веществ.

15. Прозрачность - относительно велика. Сильно поглощает лучистую энергию солнца в инфракрасной и ультрафиолетовой областях спектра; в видимой области спектра наблюдается 
относительно малое избирательное поглощение, поэтому вода бесцветна: особенности поглощения важны для физических, химических и биологических процессов.

16. Скорость звука в воде. Для всех жидкостей, кроме воды, скорость звука уменьшается с повышением температуры. Зависимость скорости звука в воде от температуры при атмосферном давлении не линейна. При нагревании воды от 0 до $70{ }^{\circ} \mathbf{C}$ скорости звука в воде увеличивается от 1403 до $1555 \mathrm{M} / \mathrm{c}$, затем в интервале температуры $70-85{ }^{\circ} \mathrm{C}$ значение этой величины остается практически постоянным При температуре выше $85{ }^{\circ} \mathrm{C}$ скорость звука в воде уменьшается и при температуре кипения достигает величины $1543 \mathrm{~m} / \mathrm{c}$.

17. В «стеснённых условиях» молекула воды меняет свойства. Вода, попав в тесные каналы внутри бериллового кристалла $\mathrm{Be}_{3} \mathrm{Al}_{2} \mathrm{Si}_{6} \mathrm{O}_{18}$., переходит в особое квантовое состояние с «размазанными» атомами водорода [176]. Подобное туннелирование имеет место и в других ситуациях, когда вода находится в сильно «стесненных» условиях.

18. Замораживая и размораживая нанотрубки разных размеров, заполненные водой -оказалось, что температура замерзания и плавления воды изменилась внутри изолированных углеродных нанотрубок разного диаметра $(1,05,1,06,1,15,1,24,1,44$ и 1,52 нм) гораздо сильнее, чем предсказывала теория [177]. Уменьшение нанотрубок приводило сдвигу в температуре таяния льда - при их сужении на 0,1 нанометра температура таяния в среднем повышалась на 10-20 градусов. Благодаря этому вода в самых тонких нанотрубках, диаметр которых составлял 1,05 и 1,06 нм. Соответственно, таяла при температуре $105-151{ }^{\circ} \mathrm{C}$ и $87-$ $117^{\circ} \mathrm{C}$.

19. Авторы работы [176] нашли у воды аномальное свойство, которое выражается в том, что одни ее молекулы (пара-изомеры) вступают в химическую реакцию лучше, чем другие (ортоизомеры). 


\section{Орто- $\mathrm{H}_{2} \mathrm{O}$}

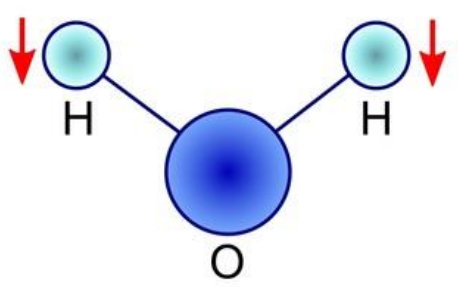

Пара- $\mathrm{H}_{2} \mathrm{O}$

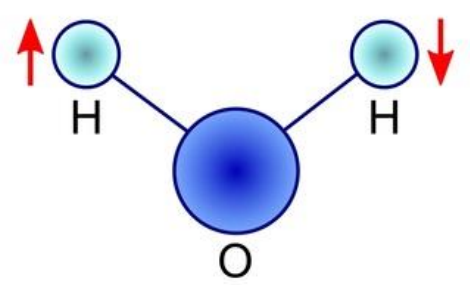

Рис.2.1. Структура орто-и пара водьл.

Оказалось, что вращательная симметрия молекул пара-воды делала их на 23 процента более реакционноспособными, чем орто-вода.

20. В нормальных условиях концентрации орто- и параизомеров молекул воды относятся как 3:1. Процедура измерения отношения орто- и параизомеров молекул воды включала следующие этапы [177].

21. Горячая вода застывает быстрее холодной. Это противоречит логике и общему восприятию вещей. Парадоксальность в том, что время, в течение которого тело остывает до температуры окружающей среды, должно быть пропорционально разности температур этого тела и окружающей среды. Этот закон был установлен еще Ньютоном и с тех пор много раз подтверждался на практике. В данном же эффекте вода с температурой $100^{\circ} \mathrm{C}$ остывает до температуры $0^{\circ} \mathrm{C}$ быстрее, чем такое же количество воды с температурой $35^{\circ} \mathrm{C}$. Это феномен назван эфектом Мпембе в честь танзанийского ученого Эрасто Бартоломео Мпембы [178]. 


\subsubsection{2. Химические реакции образования нефти с участием воды}

Как показано, основными компонентами синтеза УВ в мантии и астеносфере являются карбиды, нитриды и силициды металлов, углерод, $\mathrm{CO}, \mathrm{CO}_{2}, \mathrm{H}_{2}, \mathrm{H}_{2} \mathrm{O}$ и т.д. Учитывая, что основные реакции синтеза воды в этих условиях протекают по реакциям с одновременным образованием метана и воды:

$$
3 \mathrm{H}_{2}+\mathrm{CO} \rightarrow \mathrm{H}_{2} \mathrm{O}+\mathrm{CH}_{4} \text { или } 4 \mathrm{H}_{2}+\mathrm{CO}_{2} \rightarrow 2 \mathrm{H}_{2} \mathrm{O}+\mathrm{CH}_{4}
$$

В процесе образования УВ участвуют также метеогенные воды, которые проникают в земную кору до глубин 10 км и более (см. табл. 2.2).

Таблийа 2.2.

Константы круговорота воды, углекислоты, кислорода и азота в современную эпоху.

\begin{tabular}{|l|c|}
\hline \multicolumn{1}{|c|}{ Тип круговорота } & $\begin{array}{c}\text { Геохимическая константа } \\
\text { круговорота, г/год }\end{array}$ \\
\hline $\begin{array}{l}\text { Климатический (метеогенный) } \\
\text { круговорот вод [162] }\end{array}$ & $5.2 \pm 0.510^{20}$ \\
\hline $\begin{array}{l}\text { Геологический круговорот вод } \\
\text { Мирового океана [162] }\end{array}$ & $2.64 \pm 0.5310^{17}$ \\
\hline Польный водообмен [162] & $2.0 \pm 0.510^{19}$ \\
\hline Биосферный круговорот СО 2 & $2.56 \pm 0.5110^{17}$ \\
\hline Круговорот атмосферного кислорода & $2.75 \pm 0.0510^{17}$ \\
\hline метеогенный круговорот азота & $1.0410^{17}$ \\
\hline Биосферный круговорот азота & $1.1 \pm 0.110^{16}$ \\
\hline
\end{tabular}

Многие химические реакции протекают только в присутствии воды, то есть вода является растворителем, реагентом и катализатором для многих реакций синтеза УВ [179-181]. Так, в экспериментах Биссона водород получился по этой реакции:

$$
3 \mathrm{Fe}+4 \mathrm{H}_{2} \mathrm{O} \rightarrow \mathrm{Fe}_{3} \mathrm{O}_{4}+4 \mathrm{H}_{2},
$$




$$
\begin{gathered}
\mathrm{CO}_{2}+4 \mathrm{H}_{2} \rightarrow \mathrm{CH}_{4}+2 \mathrm{H}_{2} \mathrm{O}, \\
\mathrm{nCO}_{2}+(2 \mathrm{n}+0.5 \mathrm{~m}) \mathrm{H}_{2} \rightarrow \mathrm{C}_{n} \mathrm{H}_{\mathrm{m}}+2 \mathrm{nH}_{2} \mathrm{O} .
\end{gathered}
$$

По карбидной гипотезе вода проникает вглубь земли по трещинам в осадочных и кристаллических породах до магмы, где реагирует с карбидами тяжелых металлов вообще и, в частности, с карбидами железа, образуя углеводороды:

$$
\begin{gathered}
2 \mathrm{FeC}+3 \mathrm{H}_{2} \mathrm{O} \rightarrow \mathrm{Fe}_{2} \mathrm{O}_{3}+\mathrm{C}_{2} \mathrm{H}_{6}, \\
\mathrm{Fe}_{3} \mathrm{C}+\mathrm{H}_{2} \mathrm{O} \rightarrow \mathrm{Fe}_{3} \mathrm{O}_{4}+\mathrm{C}_{n} \mathrm{H}_{2 \mathrm{n}+2}+\mathrm{C}_{\mathrm{m}} \mathrm{H}_{2 \mathrm{~m}}
\end{gathered}
$$

Вода реагирует также с нитридами, силицидами и гидридами металлов:

$$
\begin{gathered}
\mathrm{Ca}_{3} \mathrm{~N}_{2}+6 \mathrm{H}_{2} \mathrm{O} \rightarrow 3 \mathrm{Ca}(\mathrm{OH})_{2}+2 \mathrm{NH}_{3} \\
\mathrm{TiN}+3 \mathrm{H}_{2} \mathrm{O} \rightarrow \mathrm{Ti}(\mathrm{OH})_{3}+\mathrm{NH}_{3} \\
\mathrm{Na}_{2} \mathrm{Si}+3 \mathrm{H}_{2} \mathrm{O} \rightarrow \mathrm{Na}_{2} \mathrm{SiO}_{3}+3 \mathrm{H}_{2} \\
\mathrm{SiH}_{4}+2 \mathrm{H}_{2} \mathrm{O} \rightarrow \mathrm{SiO} \mathbf{H}_{2}+4 \mathrm{H}_{2} \\
\mathrm{CaH}_{2}+2 \mathrm{H}_{2} \mathrm{O} \rightarrow \mathrm{Ca}(\mathrm{OH})_{2}+\mathrm{H}_{2}
\end{gathered}
$$

Метаногенез происходит с помощью гидролиза оливина в серпентин в присутствии двуокиси углерода, а в отсутствии двуокиси углерода- образуется водород:

$$
\begin{gathered}
4 \mathrm{Fe}_{2} \mathrm{SiO}_{4}+\mathbf{1 2 M g}_{2} \mathrm{SiO}_{4}+\mathrm{18H}_{2} \mathrm{O}+\mathrm{CO}_{2} \rightarrow \\
4 \mathrm{Mg}_{6}\left[\mathrm{Si}_{4} \mathrm{O}_{10}\right](\mathrm{OH})_{8}+4 \mathrm{Fe}_{2} \mathrm{O}_{3}+\mathrm{CH}_{4}, \\
\mathrm{Fe}_{2} \mathrm{SiO}_{4}+3 \mathrm{Mg}_{2} \mathrm{SiO}_{4}+5 \mathrm{H}_{2} \mathrm{O} \rightarrow \mathrm{Mg}_{6}\left[\mathrm{Si}_{4} \mathrm{O}_{10}\right](\mathrm{OH})_{8}+\mathrm{Fe}_{2} \mathrm{O}_{3}+\mathrm{H}_{2}
\end{gathered}
$$

Магматический магнетит обеспечивает абиотический крекинг метана в высшие углеводороды в гидротермальных условиях:

$$
3 \mathrm{CH}_{4}+10 \mathrm{Fe}_{3} \mathrm{O}_{4}+4 \mathrm{H}_{2} \mathrm{O} \rightarrow \mathrm{C}_{2} \mathrm{H}_{6}+15 \mathrm{Fe}_{2} \mathrm{O}_{3}+\mathrm{H}_{2} \mathrm{CO}_{3} \text {. }
$$

В мантийных условиях из вюстита кальцита и воды наряду с углеродом обнаруживаются также углеводороды, по реакции:

$$
\begin{aligned}
& \mathrm{nCaCO}_{3}+(9 \mathrm{n}+3) \mathrm{FeO}+(2 \mathrm{n}+1) \mathrm{H}_{2} \mathrm{O} \rightarrow \\
& \mathrm{nCa}(\mathrm{OH})_{2}+(3 \mathrm{n}+1) \mathrm{Fe}_{3} \mathrm{O}_{4}+\mathrm{C}_{n} \mathrm{H}_{2 n+2}+\mathrm{C} .
\end{aligned}
$$




\section{2. Роль C-H-O-S системы (серы) в генезисе нефти}

Общее содержание серы в земной коре сравнительно небольшое (около $0.026 \%$ ), однако как элемент - анионообразователь она занимает второе место после кислорода, связывая в виде сульфидов всю массу 15 халькофильных элементов земной коры и некоторую часть железа в виде пирротина или пирита. Около $20 \%$ серы земной коры находится в виде сульфатов литофильных элементов. Характерной геохимической особенностью серы является то, что в земной коре она распределена крайне неравномерно. На долю самородной серы приходится сравнительно небольшая часть из общего ее содержания в земной коре. Основное ее количество находится в природе в виде соединений сульфидного (серный колчедан, медный колчедан, цинковая обманка, свинцовый блеск и др.) и сульфатного (гипсоангидрит, гипс, мирабилит и т.д.), а также в различном виде в каменном угле, нефти, природном газе, битуминозных песчаниках и т.п [182].

В нефтях содержатся как неорганические, так и органические соединения серы: элементарная сера, сероводород, тиолы или меркаптаны, сульфиды, ди- и полисульфиды, тиофены [4,5,153].

По Г. Биассону [15], происхождение нефти объясняется путем взаимодействия воды, $\mathrm{CO}_{2}$ и $\mathrm{H}_{2} \mathrm{~S}$ с раскаленным железом.

$$
\begin{gathered}
\mathrm{CO}_{2}+2 \mathrm{H}_{2} \mathrm{~S} \rightarrow \mathrm{CS}_{2}+2 \mathrm{H}_{2} \mathrm{O}, \\
3 \mathrm{Fe}+4 \mathrm{H}_{2} \mathrm{O} \rightarrow \mathrm{Fe}_{3} \mathrm{O}_{4}+4 \mathrm{H}_{2}, \\
\mathrm{CS}_{2}+4 \mathrm{H}_{2} \rightarrow 2 \mathrm{H}_{2} \mathrm{~S}+\mathrm{CH}_{4} .
\end{gathered}
$$

Маракушев А.И. показал пространственную связь углеводородов и сульфидных руд [24]:

\section{$7 \mathrm{Fe}_{2} \mathrm{SiO}_{4}+28 \mathrm{H}_{2} \mathrm{~S}+4 \mathrm{CO}_{2} \rightarrow 14 \mathrm{FeS}_{2}+7 \mathrm{SiO}_{2}+22 \mathrm{H}_{2} \mathrm{O}+\mathrm{C}_{2} \mathrm{H}_{6}$.}

В работах $[38,39]$ показано,что взаимодействие $\mathrm{CH}_{4} \mathrm{c} \mathrm{S}$ при мантийных условиях приводит к образованию различных S-co- 
держащих соединений и более высокомолекулярных углеводородов:

$$
\begin{gathered}
\mathrm{CH}_{4}+4 \mathrm{~S} \rightarrow 4 \mathrm{H}_{2} \mathrm{~S}+\mathrm{CS}_{2}, \\
\mathrm{CH}_{4}+2 \mathrm{~S} \rightarrow 2 \mathrm{H}_{2}+\mathrm{CS}_{2}, \\
\mathrm{nCS}_{2}+(2 \mathrm{n}+0.5 \mathrm{~m}) \mathrm{H}_{2} \rightarrow 2 \mathrm{nH}_{2} \mathrm{~S}+\mathrm{C}_{\mathrm{n}} \mathrm{H}_{\mathrm{m}}, \\
2 \mathrm{C}_{\mathrm{n}} \mathrm{H}_{2 \mathrm{n}}+\mathrm{H}_{2} \mathrm{~S} \rightarrow\left(\mathrm{C}_{\mathrm{n}} \mathrm{H}_{2 \mathrm{n}+1}\right)_{2} \mathrm{~S} .
\end{gathered}
$$

Синтез УВ на основе реакции Росса:

$$
2 \mathrm{CaCO}_{3}+2 \mathrm{SO}_{2}+4 \mathrm{H}_{2} \mathrm{~S} \rightarrow 2 \mathrm{CaSO}_{4} \times 2 \mathrm{H}_{2} \mathrm{O}+4 \mathrm{~S}+\mathrm{C}_{2} \mathrm{H}_{4} .
$$

Одним из плохо объяснимых явлений до сих пор остается отсутствие олефинов в подавляющем большинстве нефти. Видимо, это обусловлено их высокой реакционной способностью и вступлением в реакции гидрирования с $\mathrm{H}_{2} \mathrm{~S}$ с образованием меркаптанов [183]:

$$
\begin{gathered}
\mathrm{CH}_{2}=\mathrm{CH}-\mathrm{X}+\mathrm{H}_{2} \mathrm{~S} \rightarrow \mathrm{HS}-\mathrm{CH}_{2}-\mathrm{CH}_{2}-\mathrm{X}, \\
\mathrm{CH}_{2}=\mathrm{CH}-\mathrm{X}+\mathrm{HS}-\mathrm{CH}_{2}-\mathrm{CH}_{2}-\mathrm{X} \rightarrow \mathrm{S}\left(\mathrm{CH}_{2}-\mathrm{CH}_{2}-\mathrm{X}\right)_{2} .
\end{gathered}
$$

\section{3. Роль $\mathrm{C}-\mathrm{H}-\mathrm{O}-\mathrm{S}-\mathrm{N}$ системы (азота) в генезисе нефти} 2.3.1. Распределение азота в биосрере

После водорода, гелия и кислорода азот -четвёртый по распространённости элемент в солнечной системе. Азот-один из элементов, выделившихся в газовой фазе в начале формирования Земли в процессе дегазации. В дальнейшем выделение газообразных соединений азота из недр Земли продолжалось при извержении вулканов, выносе гидротерм и газовых струй.

Так как газообразный молекулярный азот благодаря химической инертности является наиболее устойчивой формой нахождения его, по этой причине $\mathrm{N}_{2}(\mathrm{~N} \equiv \mathrm{N})$ изначально аккумулировался в атмосфере, а не концентрировался в форме нерастворимых соединений в осадках Мирового океана, как углерод в составе 
карбонатных толщ или в форме растворенных соединений в воде Мирового океана, как хлор.

Основная масса азота в форме $\mathrm{N}_{2}$ сосредоточена в атмосфере, точнее в тропосфере, где содержится $3.87 \times 10^{15}$ т азота [184].

Состав атмосферного азота непрерывно обновляется благодаря циклическим процессам массообмена, связывающим атмосферу с Мировой сушей, педосферой, живым веществом, океаном и его осадками.

Один из круговоротов азота обусловлен фотохимическими реакциями в тропосфере. Так, в атмосфере кроме свободного азота находятся также $\mathrm{NH}_{3}, \mathrm{~N}_{2} \mathrm{O}, \mathrm{NO}, \mathrm{NO}_{2}$. Благодаря фотохимическим реакциям с участием паров воды и оксидов азота образуются азотистая и азотная кислоты, а в дальнейшем их соли нитриты и нитраты. Кроме того, определенное количество азота, окисляемого в результате электрических разрядов, и затем вымывается в виде иона $\mathrm{NO}_{3}^{-}$. В кислородсодержащей атмосфере аммиак реагирует с оксидами серы и образует кислый сульфат аммония $\mathrm{NH}_{4} \mathrm{HSO}_{4}$. Это соединение, так же как нитриты и нитраты, легко вымывается атмосферными осадками.

Таблица 2.3.

Количество азота в природе.

\begin{tabular}{|l|c|}
\hline \multicolumn{1}{|c|}{ Среда } & Количество азота, т \\
\hline Растение & $9.0 \times 10^{8}$ \\
\hline Животные & $3.1 \times 10^{10}$ \\
\hline Почва & $(0.6-1.5) \times 10^{11}$ \\
\hline Мировая суша & $2.2510^{11}$ \\
\hline Земная кора & $(0.7-1.5) \times 10^{15}$ \\
\hline Мировой океан & $6.85 \times 10^{11}$ \\
\hline Воздух & $3.87 \times 10^{15}$ \\
\hline Мантия Земли & $(0.4-1.3) \times 10^{16}$ \\
\hline
\end{tabular}

Круговорот азота, обусловленный его бактериальной фиксацией и дальнейшей трансформацией, тесно связан с другим мощным круговоротом этого элемента. Крупные массы нитратного и 
аммонийного азота захватываются водами Мирового океана и педосферы в биологический круговорот, происходящий благодаря деятельности фотосинтезирующих растений и микроорганизмов, разрушающих растительные остатки. Количество азота в организмах животных и растений составляют соответственно $3.1 \times 10^{10}$ т. и $9.0 \times 10^{8}$ т.

Часть газа $\mathrm{N}_{2}$ растворена в воде Мирового океана. В океане азот присутствует также в виде растворенных ионов, в составе растворенного и дисперсно-взвешенного органического вещества. Масса азота, находящегося в форме растворенных ионов $\left[\mathrm{NH}_{4}\right]^{+},\left[\mathrm{NO}_{2}\right]^{-}$и $\left[\mathrm{NO}_{3}\right]^{-}$, составляет $6.85 \times 10^{11} \mathrm{~T}$.

Содержание азота в земной коре, по данным разных авторов, составляет от 0,7 до $1,5 \times 10^{15}$ т. По расчетам Соротхина [184] в мантии Земли количество азота приблизительно $4,07 \cdot 10^{15} \mathrm{~T}$, по другим источникам $-1,3 \cdot 10^{16}$ т. более [185]. Такое соотношение масс заставляет предположить, что главным источником азота служит верхняя часть мантии, откуда он поступает в другие оболочки Земли с извержениями вулканов. Метеогенная вода переносит до глубины 10 км и более азот массой 1,04 10 ${ }^{17}$ г/год.

С увеличением стратиграфического возраста пород содержание азота возрастает также в подземных водах нефтегазоносного бассейна [186]. Подобная картина наблюдается в газах газовых залежей и в попутных газах нефтей, а также в газах газовых шапок. Зачастую в газовых залежах содержание $\mathrm{N}_{2}$ достигает $75 \%$ и более.

В газовых залежах содержание азота изменяется от долей процента, до чисто азотных скоплений.

Важным источником молекулярного азота является выделившийся в процессе метоморфизма осадочных пород связанный азот. В метаморфических породах содержание азота - от 18 до 390 г/т в зависимости от степени метаморфизма пород. В магматических породах содержание азота изменяется от 5 до 50 г/т. 
Азот поступает и с более глубоких горизонтов при подводном вулканизме.

\subsection{2. Закономерности распределения азота в нефти}

Содержание азота в нефти редко превышает 1\% [3,30,44,45]. Оно снижается с глубиной залегания нефти и мало зависит от характера вмещающих их пород. Азотистые соединения сосредоточены в высококипящих фракциях и особенно в тяжелых остатках. Обычно азотсодержащие соединения нефти делят на две большие группы: азотистые основания и нейтральные азотистые соединения. Азотистые основания сравнительно легко выделяются минеральными кислотами и потому наиболее изучены. В настоящее время в нефти и его фракциях выделено более 50 индивидуальных азотистых оснований. Алкиламины в нефти не обнаружены. Амины основного характера представлены преимущественно третичными аминами - производными пиридина, хинолина, изохинолина, в меньшей степени акридина. Значительно реже представлены гомологи анилина. Нейтральные азотсодержащие соединения нефти представлены арилпроизводными пиррола, индола, карбазола, бензокарбазола и амидами кислот. Убедительных доказательств наличия в нефти самого пиррола и простейших его алкилзамещенных пока нет.

В работе [187] изучено распределение низкомолекулярных азотсодержащих компонентов в нефти и рассеянном органическом веществе Верхнеюрского комплекса Западной Сибири. Установлено, что их количество в органическом веществе пород выше, чем в соответствующих видах нефти. Азотистые основания рассеянного органического вещества отличаются от нефтяных повышенным содержанием слабоосновных компонентов и структур с малоэкранированным атомом азота. Получается хорошая корреляция между количеством неосновного и основного азотистых соединений. 


$$
\begin{gathered}
\mathbf{N}_{\text {неосн }}=(\mathbf{0 . 0 0 5} \pm 0.007)+(3.473 \pm 0.334) \cdot \mathbf{N}_{\text {осн }} \\
\mathbf{R}^{2}=\mathbf{0 . 9 5 6 7}, \mathbf{N}=12 .
\end{gathered}
$$

Встречаются также соединения, содержащие в молекуле одновременно атомы азота и серы.

Наблюдаются прямые корреляции между содержанием $N, S$, $O$, ароматических структур, металлов $(\mathrm{Ni}, \mathrm{V})$, асфальтосмолистых компонентов с величиной вязкости и плотности нефти [38,39,188]. Содержание азота прямо коррелирует с серой и с количественным соотношением V / Ni [188]. Следует отметить, что в нефти юрско-палеозойских отложений Западной Сибири общее содержание азота $\left(\mathrm{N}_{\text {общ}}\right)$ в изученных нефтях изменяется от 0,05 до $0,16 \%$, содержание основного азота $\left(\mathrm{N}_{\text {осн }}\right)$ - от 0,009 до 0,054 \% мас. [189]. Для юрской нефти наблюдается тенденция к снижению вниз по разрезу доли основного азота. С повышением глубины катагенной преобразованности нефти среди низкомолекулярных азотистих оснований $(A O)$ также наблюдается увеличение доли азотсодержащих и уменьшение доли азотсеросодержащих соединений. Прослеживается связь между распределением низкомолекулярных $A O$ с сернистостью и смолистостью (САВ) нефти. Сравнительный анализ показывает, что малосернистые нефти $\left(\mathrm{S}_{\text {общ }}<0.50 \%\right.$ мас.) характеризуются большим, чем сернистые $\left(\mathrm{S}_{\text {общ }}>0.50 \%\right.$ мас.) относительным количеством всех типов низкомолекулярных сильных оснований. Получается следующая корреляция:

$$
\begin{aligned}
& \mathbf{N}_{(\mathrm{S}>50)}=(-0.035 \pm 1.648)+(0.806 \pm 0.150) \bullet \mathbf{N}_{(\mathrm{S}<50)}, \\
& \mathbf{R}^{2}=\mathbf{0 . 8 1 6 9}, \mathrm{N}=\mathbf{1 6} \text {. }
\end{aligned}
$$

Для малосмолистых видов нефти (САВ < $10 \%$ мас.) также отмечено большее относительное количество всех групп низкомолекулярных компонентов в составе АО, по сравнению с обогащенными одновозрастными видами нефти, (САВ > 10\% мас.). Интересным типом азотсодержащих соединений являются нефтяные порфирины, довольно подробно изученные в настоящее время. Они содержат в молекуле 4 пиррольных кольца и встречаются в нефти в виде комплексов с $N i$ и ванадилом $\mathrm{VO}^{2+}$. В природных 
нефтях ванадилпорфирины в основном - гомологи двух рядов: алкилзамещенных порфиринов (с различным суммарным числом атомов углерода в боковых заместителях порфиринового цикла) и порфиринов с дополнительным циклопентеновым кольцом. Их концентрации одного порядка.

Большое содержание порфиринов характерно для сернистых видов нефти. Содержание порфиринов в некоторых видах нефти достигает $0,1 \%$, Металлопорфириновые комплексы присутствуют в природных битумах в количестве до 1 мг/100 г, а в высоковязких нефтях - до 20 мг/100 г. Установлено, что 40 \% ванадилпорфиринов сосредоточено в дисперсных частицах, а оставшаяся их часть (и никель-порфирины тоже) содержится в дисперсной среде. Кстати, оба вида металлопорфиринов в составе асфальтенов вносят значительный вклад в поверхностную активность нефтей.

\subsection{3. Азот в мантии}

Как было показано, в мантии количество азота составляет от 0,4 до $1,3 \times 10^{15}$ т. Однако авторами работы[185]. показано, что общая масса азота в ядре должна составлять $9660 \times 10^{15}$ т., а в ман-

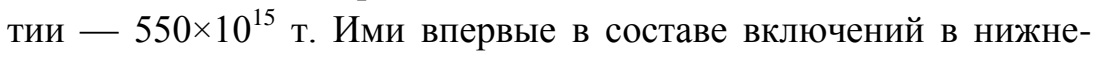
мантийных алмазах из кимберлитов Рио-Сорисо (Бразилия) были обнаружены нитриды и карбонитриды железа. Среди нитридов идентифицированы тригональный $\mathrm{Fe}_{3} \mathrm{~N}$ и орторомбический $\mathrm{Fe}_{2} \mathrm{~N}$, среди карбонитридов - тригональный $\mathrm{Fe}_{9}\left(\mathrm{~N}_{0,8} \mathrm{C}_{0,2}\right)_{4}$ в сочетании с карбидом железа $\mathrm{Fe}_{7} \mathrm{C}_{3}$, карбидом кремния $\mathrm{SiC}$, а также оксидами $\mathrm{Cr}, \mathrm{Mn}, \mathrm{Fe}$ и $\mathrm{Mn}, \mathrm{Fe}$. Обнаружен широкий ряд переходных разновидностей карбонитридов от $\mathrm{Fe}_{5}(\mathrm{C}, \mathrm{N})_{3}$ до $\mathrm{Fe}_{23}(\mathrm{C}, \mathrm{N})_{6}$ с отношением $\mathrm{Fe} /(\mathrm{C}, \mathrm{N})$ от 1,65 до 3,98. Показано, что изученные нитриды и карбонитриды железа были сформированы в самой нижней мантии, что указывает на то, что крупные резервуары азота 
следует ожидать в ядре и в самой нижней мантии, обеспечивая некоторое решение проблемы баланса азота.

В мантийных условиях возможны существования некоторых нитридов. Так, нитрид Fe образуется из смеси Fe и $\mathrm{N}$ при более $1700^{\circ} \mathrm{C}$ и 520 кбар [190], TiN в виде порошка, устойчив до $1300^{\circ} \mathrm{C}$ и 77 кбар [191]. Показано, что $\mathrm{HfN}_{10}$, который одновременно имеет бесконечные крестообразные полимерные N-цепи и молекулы $\mathrm{N}_{2}$ в своей кристаллической структуре, стабилен при умеренном давлении выше 23 ГПа и может поддерживаться в качестве метастабильной фазы при атмосферном давлении [192]. В работе [193] прогнозируется, что под давлением приосходит стабилизация $\mathrm{Cr}_{2} \mathrm{~N}, \mathrm{CrN}$ и нового соединения $\mathrm{CrN}_{4}$. Богатый азотом нитрид хрома $\mathrm{CrN}_{4}$ представляет собой материал с высокой удельной энергией, содержащий полимерные азотные цепи. При наличии атомов металла (например, $\mathrm{Cr}$ ) полимеризация азота происходит при значительно более низких давлениях; $\mathrm{CrN}_{4}$ становится стабильным при 15 ГПа ( 110 ГПа для синтеза чистого полимерного азота).Использовав эволюционный алгоритм предсказания молекул USPEX (Universal Structure Predictor: Evolutionary Xtallography), Артем Оганову и сотрудникам удалось доказать, что нетипичные соединения, такие как $\mathrm{N}_{8} \mathrm{H}, \mathrm{N}_{4} \mathrm{H}, \mathrm{N}_{3} \mathrm{H}$, $\mathrm{N}_{9} \mathrm{H}_{4}, \mathrm{~N}_{2} \mathrm{H}, \mathrm{NH}, \mathrm{NH}_{2}, \mathrm{~N}_{3} \mathrm{H}_{7}, \mathrm{NH}_{4}$ и $\mathrm{NH}_{5}$, стабильны при высоком давлении и обладают некоторыми необычными свойствами [194].

В работах [19-22] показано, что азот в РТ - условиях нижней мантии становится одним из самых химически активных элементов. В составе мантийного газа относительно много $\mathrm{N}$ - содержащих углеводородов (дициан и дицианацетилен). В составе флюида, кроме $\mathrm{N}_{2}$, содержится значительное количество $\mathrm{NH}_{3}$. На основе экспериментальных материалов показано, что в продуктах плавления ранней мантии Земли - в силикатных расплавах [53] при высоком давлении, температуры и низких значениях химического потенциала кислорода образуются силикатные стекла с высокой концентрацией $\mathrm{CH}_{4}, \mathrm{H}_{2}, \mathrm{NH}_{3}, \mathrm{~N}_{2}$. 
В работе [33,53] утверждается, что в нижней мантии от тепла ядра Земли, в результате распада карбидов, нитридов, гидридов и оксидов образуются газообразные соединения $\mathrm{NO}, \mathrm{N}_{2} \mathrm{O}, \mathrm{N}_{2} \mathrm{O}_{4}$, $\mathrm{N}_{2} \mathrm{O}_{5}, \mathrm{HCN}, \mathrm{O}_{3}, \mathrm{~N}_{2} \mathrm{H}_{4}, \mathrm{NH}_{3}, \mathrm{C}_{2} \mathrm{H}_{2}, \mathrm{C}_{2} \mathrm{H}_{4}$. При поднятии этих газообразных соединений давление в них снижается, газы расширяются, из-за этого охлаждаются, и в условиях астеносферы по термодинамическим характеристикам элементы этих газов наиболее стабильны в виде соединений с большим молекулярным весом, которые получили название нитронефть. В мантии также синтезируются металлоорганические соединения, органосилоксаны, карбонилы, которые растворяются в нитронефти. Согласно данным работы [33], в нитронефти присутствуют непредельные углеводороды, перекиси, амины, гидразин, озон и нитропарафины (нитрометан, гексанитроэтан и т.д.), нитроароматические соединения (тринитротолуол, гексанитробензол и т.д.), нитроамины (гексоген- $\mathrm{C}_{3} \mathrm{H}_{6} \mathrm{~N}_{6} \mathrm{O}_{6}$, октоген- $\mathrm{C}_{4} \mathrm{H}_{8} \mathrm{~N}_{8} \mathrm{O}_{8}$ ), карбонилы $\mathrm{Fe}(\mathrm{CO})_{5}$, $\mathrm{Ni}(\mathrm{CO})_{4}$, металлоорганические соединения, кремнеорганические соединения (органосилоксаны), сера, и $\mathrm{SO}_{3}$.

\subsection{4. Химические реакции образования нефти с участием азота}

Так как азот, являясь одним из основных компонентов нефти, принимает участие в образовании нефти во всех стадиях нефтегенеза [3,44,45,196,197], в работе [198] исследовано влияние разбавления синтез газа азотом на процесс синтеза углеводородов из $\mathrm{CO}$ и $\mathrm{H}_{2}$ в присутствии $\mathrm{Co}-\mathrm{Al}_{2} \mathrm{O}_{3}$ катализаторов, в том числе промотированных $\mathrm{ZrO}_{2}$ и $\mathrm{CeO}_{2}$. Показано, что в результате разбавления сырья(31\% CO и 64\% $\left.\mathrm{H}_{2}\right)$ азотом $\left(57 \% \mathrm{~N}_{2}\right.$, $13,5 \%$ СO и $27 \% \mathrm{H}_{2}$ ) возрастает конверсия $C O$ (с 16 до $53 \%$ ), селективность по метану - возросла (с 3 до $8 \%$ ), а селективность по высшим углеводородам несколько снизилась (с 95 до 90\%). Влия- 
ние разбавления на температурную зависимость селективности процесса по выходам углеводородов $\mathrm{C}_{5}$ и по метану позволяет предположить, что разбавление сырья инертным газом является определяющим. Разбавления сырья в присутствии азота $\mathrm{CO}_{2}(7 \%$ $\mathrm{CO}_{2}, 57 \% \mathrm{~N}_{2}, 12 \% \mathrm{CO}$ и $24 \% \mathrm{H}_{2}$ ), можно заметить - в присутствии $\mathrm{CO}_{2}$ конверсия $C O$ осталась на уровне $53 \%$, а селективность по высшим углеводородам несколько возросла (с 90 до 96\%), при этом селективность по метану снизилась (с 8 до $3 \%$ ).

Установлено, что увеличение количества $\mathrm{CO}_{2}$ (с 7 до $20 \%$ ) и уменьшение количества азота (с 57 до $24 \%$ ) при синтезе углеводородов из $\mathrm{CO}$ и $\mathrm{H}_{2}$ на катализаторе $\mathrm{Co}-\mathrm{ZrO}_{2} / \mathrm{Al}_{2} \mathrm{O}_{3}$ приводит к снижению конверсии СО с 53 до $43 \%$, селективности по углеводородам $\mathrm{C}_{5}$ (с 90 до $86 \%$ ) и повышению селективности по метану (с 8 до $11 \%$ ) при $200^{\circ} \mathrm{C}$ и 1 МПа.

Важные закономерности установлены при экспериментальном исследовании каталитических свойств ряда пород и минералов и термодинамическом моделировании взаимодействия мантийного флюида $\left(\mathrm{CO}, \mathrm{H}_{2}\right)$ в присутствии азота и литосферы [199]. В лабораторной установке газ $\left(\mathrm{CO}, \mathrm{H}_{2}, \mathrm{~N}_{2}\right)$ фильтровался при 300$600^{\circ} \mathrm{C}$ и 30-80 кбар через раздробленные образцы (фракция 0,52,0 мм). В результате было установлено, что в ксенолите лерцолита из щелочного пикробазальта, хромите, хромдиопсиде и альмандине синтезируется в основном $\mathrm{CH}_{4}$ и $\mathrm{CO}_{2}$, а в зависимом количестве присутствуют ближайшие гомологи метана, олефины, метанол $\left(\mathrm{CH}_{3} \mathrm{OH}\right)$ и диметилэфир $\left(\mathrm{CH}_{3} \mathrm{OCH}_{3}\right)$. Базальт проявляет каталитические свойства в образовании метана (до 18 мас. \%) и его гомологов.

При поднятии нитронефти до глубин менее 10 км, нитронефть разлагается с образованием нефти, воды, $\mathrm{N}_{2}, \mathrm{CO}_{2}$ рудных образований, гипсов и известняков. В случае избытка водорода в составе нитронефти происходит образование природного газа. 
При избытке кислорода нитронефть разлагается без образования углеводородов [3].

Вода, проникая в глубь земли по трещинам в осадочных и кристаллических породах до магмы, реагирует с нитридами тяжелых металлов, образует аммиак:

$$
\begin{aligned}
\mathrm{Ca}_{3} \mathrm{~N}_{2}+6 \mathrm{H}_{2} \mathrm{O} & \rightarrow \mathrm{Ca}(\mathrm{OH})_{2}+2 \mathrm{NH}_{3}, \\
\mathrm{TiN}+3 \mathrm{H}_{2} \mathrm{O} & \rightarrow \mathrm{Ti}(\mathrm{OH})_{3}+\mathrm{NH}_{3} .
\end{aligned}
$$

При $1000^{\circ} \mathrm{C}$ аммиак реагирует с углём, образуя синильную кислоту $H C N$ и частично разлагаясь на азот и водород:

$$
\mathrm{C}+\mathrm{NH}_{3} \rightarrow \mathrm{HCN}+\mathrm{H}_{2} \text {. }
$$

Непосредственное образование цианистого водорода из метана и аммиака основано на эндотермической реакции:

$$
\mathrm{CH}_{4}+\mathrm{NH}_{3} \rightarrow \mathrm{HCN}+3 \mathrm{H}_{2} \text {. }
$$

Высокие выходы с одновременным значительным повышением скорости реакции достигаются при каталитическом осуществлении процесса (например, на платиновом и других катализаторах). На катализаторе возможно образование радикалов и бирадикалов $\left(\mathbf{C H}_{\mathbf{3}}, \mathbf{N H}_{\mathbf{2}}, \mathbf{C H}_{\mathbf{2}}, \mathbf{N H}\right)$. Взаимодействия образующихся радикалов с метаном и аммиаком приводят к получению метиламина $\left(\mathbf{C H}_{3} \mathbf{N H}_{2}\right)$.

Из газообразных мантийных флюидов получаются почти все азотистые соединения, входящие в состав нефти [44-46,200].

$$
\mathrm{NH}_{3} \rightarrow \text { дифениламин } \rightarrow \text { карбазол. }
$$

Карбазол можно получить пропусканием дифениламина через раскаленную трубку:

$$
\begin{gathered}
\left(\mathrm{C}_{6} \mathrm{H}_{5}\right)_{2} \mathrm{NH}_{2} \rightarrow \text { карбазол }+\mathrm{H}_{2} \cdot \\
\mathrm{NH}_{3} \rightarrow \text { анилин } \rightarrow \text { индол. }
\end{gathered}
$$

Индол можно получить реакцией Чичибабина продувкой смеси анилина с ацетиленом через раскаленную трубку: 


\section{$\mathrm{C}_{6} \mathrm{H}_{5} \mathrm{NH}_{2}+\mathrm{C}_{2} \mathrm{H}_{2} \rightarrow$ индол $+\mathrm{H}_{2}$. \\ $\mathrm{NH}_{3} \rightarrow$ пиридин и т.Д.}

Пиридин легко получается по реакции Рамзая пропусканием смеси ацетилена и $\mathrm{HCN}$ через раскаленную железную трубку:

$$
2 \mathrm{C}_{2} \mathrm{H}_{2}+\mathrm{HCN} \rightarrow \mathrm{C}_{5} \mathrm{H}_{5} \mathrm{~N}
$$

2,3-диметилпиридин можно получить в поточном процессе над алюминиевым катализатором при $\mathrm{T}=400^{\circ} \mathrm{C}$ с помощью реакции Дильса- Олдера из 2,3-диметилбутадиена и ацетонитрила.

$\mathrm{NH}_{3} \rightarrow$ пиррол $\rightarrow$ порфин $\rightarrow$ VO- и Ni- порфирины.

Так, по реакции Шульте [200] в присутствии катализатора $\mathrm{CuCI}$ и при $\mathrm{T}=150^{\circ} \mathrm{C}$ из диацетилена и аммиака легко синтезируется пиррол:

$$
\mathrm{C}_{4} \mathrm{H}_{2}+\mathrm{NH}_{3} \rightarrow \mathrm{C}_{4} \mathrm{H}_{4} \mathrm{NH} .
$$

Пиррол получается также путем пропускания ацетилена с аммиаком через раскаленную трубку:

$$
2 \mathrm{HC} \equiv \mathrm{CH}+\mathrm{NH}_{3} \rightarrow \mathrm{C}_{4} \mathrm{H}_{4} \mathrm{NH}+\mathrm{H}_{2} .
$$

Пиррол по реакции Геше в присутствии воды легко превращается в пиррол $-\alpha-$-альдегид, который с муравьиной кислотой образует порфин. Из пиррола и муравьиной кислоты по реакции Геше-Фишера легко синтезируется порфин [200]:

\section{$4 \mathrm{C}_{4} \mathrm{H}_{4} \mathrm{NH}+\mathrm{HCOOH} \rightarrow$ порфин.}

Одним из плохо объяснимых явлений до сих пор остается отсутствие олефинов в подавляющем большинстве нефти. Видимо это обусловлено их высокой реакционной способностью и вступлением в реакции гидрирования, полимеризации и взаимодействия c $\mathrm{H}_{2} \mathrm{~S}, \mathrm{NH}_{3}, \mathrm{C}_{\mathrm{n}} \mathrm{H}_{\mathrm{m}} \mathrm{NH}_{2}$ и $\left(\mathrm{C}_{\mathrm{n}} \mathrm{H}_{\mathrm{m}}\right)_{2} \mathrm{NH}$. 
Реакции присоединения нуклеофилов по активированной двойной углерод-углерод связи широко известны под названием реакции (конденсации) Микаэля [201]:

$$
\left.\mathrm{CH}_{2}=\mathrm{CHX}+\left(\mathrm{C}_{\mathrm{n}} \mathrm{H}_{\mathrm{m}}\right)_{2} \mathrm{NH} \rightarrow \mathrm{C}_{\mathrm{n}} \mathrm{H}_{\mathrm{m}}\right)_{2} \mathrm{~N}-\mathrm{CH}_{2}-\mathrm{CH}_{2} \mathrm{X} .
$$

В работах [58,202-206] нами показано, что $\alpha, \beta$-ненасыщенные соединения (акрилонитрил, акриламид, метакриламид, метакрилат, метилметакрилат, бутилакрилат) и $\alpha, \beta$-ненасыщенные поверхностноактивные соединения взаимодействуют со вторичными аминами (пиперидин, морфолин, диэтиламин, дипропиламин, дибутиламин, диэтаноламин) в воде, в органических растворителях и в смесях вода - органический сорастворитель, образуя соответствующие третичные амины. Механизм взаимодействия винилацетата с диэтиламином, пиперидином и морфолином отличается от классического механизма реакции Михаэля. Продуктами реакции являются соответствующие амиды уксусной кислоты и енамины. В условиях этой реакции в результате вторичных превращений енамина установлено образование полисопряженного олигомера, обладающего парамагнитизмом [207].

Амины также взаимодействуют с радикалами: свободными иминоксильными, феноксильными, кумилпероксидным и $\mathrm{HO}$ [204] и с макрорадикалами [208].

Продукты реакций первичных и вторичных аминов с $\alpha$, $\beta$-ненасыщенными соединениями (третичные алктиламины) с пероксидами образуют своеобразные иницирующие системы радикальной полимеризации ненасыщенных соединений [209, 210]. Следует отметить, что в результате реакции амин+пероксид образуется енамин, который превращается в полисопряженный полимep.

\section{4. Роль ванадия и никеля в генезисе нефти 2.4.1. Распределение ванадия и никеля в литосфере и в нефти}


Ванадий относится к рассеянным элементам и в природе в свободном виде не встречается. Содержание ванадия в земной коре $1,6 \cdot 10^{-2} \%$ по массе, в воде океанов $3 \cdot 10^{-7} \%$. Наиболее высокие средние содержания ванадия в магматических породах отмечаются в габбро и базальтах (230-290 г/т). Известно около 90 минералов ванадия. Важнейшие минералы сульфиды: патронит $\mathrm{VS}_{4}$, или $\mathrm{VS}_{2}, \mathrm{~V}_{2} \mathrm{~S}_{5}$. Ванадинит - $\mathrm{Pb}_{5} \mathrm{Cl}\left(\mathrm{VO}_{4}\right)_{5}$, деклуазид $\mathrm{Pb}(\mathrm{Zn}, \mathrm{Cu}) \mathrm{VO}_{4}$, моттрамит - $\mathrm{Pb}(\mathrm{Zn}, \mathrm{Cu}) \mathrm{VO}_{4}(\mathrm{OH})$, карнотит $\mathrm{K}_{2}\left(\mathrm{UO}_{2}\right)_{2}\left(\mathrm{VO}_{4}\right)_{2}{ }^{\cdot} \mathrm{H}_{2} \mathrm{O}$, тюямунит $-\mathrm{Ca}\left(\mathrm{UO}_{2}\right)_{2}\left(\mathrm{VO}_{4}\right)_{2}{ }^{\cdot} 8 \mathrm{H}_{2} \mathrm{O}$ [211]. Близость ионных радиусов ванадия и широко распространённых в магматических породах железа и титана приводит к тому, что ванадий в гипогенных процессах целиком находится в рассеянном состоянии. Его носителями являются многочисленные минералы титана, обладающие повышенной изоморфной ёмкостью по отношению к ванадию. Например, титаномагнетит (FeTi) $\mathrm{Fe}_{2} \mathrm{O}_{4}\left(\mathrm{~V}_{2} \mathrm{O}_{5}-0,15-1,5 \%\right)$.

Ванадий занимает первое место среди присутствующих в нефти металлов. Ванадий находится в количестве до $10^{-1} \%$, за ними на втором месте $\mathrm{Ni}$, а в третьем месте находится $\mathrm{Fe}\left(10^{-2} \%\right)$ [212,213]. В нефтях и твердых битумах ванадий находится в следующих формах: образует истинные растворы и коллоидные растворы, адсорбированные на активной поверхности нефть/вода, в виде металлоорганических соединений и металлопорфириновых комплексов. Следует отметить, что ванадий преобладает в золах нефтей. Для некоторых из них содержание $\mathrm{V}_{2} \mathrm{O}_{5}$ в золе достигает 70\% при зольности 0,05-0,20\% [213].

Установлено, что 40 \% ванадилпорфиринов сосредоточено в дисперсных частицах, а оставшаяся их часть содержится в дисперсной среде. Кстати, оба вида металлопорфиринов в составе асфальтенов вносят значительный вклад в поверхностную активность нефтей [212]. 
Таблииа 2.4.

Содержание ванадия в нефти месторождений России и Западного

Казахстана

\begin{tabular}{|l|c|c|}
\hline \multicolumn{1}{|c|}{ Месторождение } & $\begin{array}{c}\text { Нефтегазоносный } \\
\text { бассейн }\end{array}$ & $\begin{array}{c}\text { Содержание } \\
\text { ванадия,г/т }\end{array}$ \\
\hline Ромашкинское & Волго-Уральский & 329 \\
\hline Приобское & Западно-Сибирский & 360 \\
\hline Усинское & Тимано-Печорский & 111 \\
\hline Юсуповское & Волго-Уральский & 140 \\
\hline Новоелховское & Волго-Уральский & 569 \\
\hline Володарское & Прикаспийская впадина & 14 \\
\hline Сев. Бузачи & Западный Казахстан & $100 \div 300$ \\
\hline Каражанбас & Западный Казахстан & $70 \div 300$ \\
\hline Каламкас & Западный Казахстан & $60 \div 300$ \\
\hline Жалгызтобе & Западный Казахстан & $60 \div 200$ \\
\hline Бозоба & Западный Казахстан & $50 \div 120$ \\
\hline Акбулак & Западный Казахстан & $50 \div 400$ \\
\hline Тюбеджик & Западный Казахстан & $10 \div 70$ \\
\hline Иманкара & Западный Казахстан & $20 \div 80$ \\
\hline
\end{tabular}

В нефти в свите Офисина в пределах Восточно-Венесуэльского бассейна среднее содержание ванадия составляет 335 г/т. В девонских нефтях Альберты в Канаде ванадий содержится в среднем количестве 13,6 г/т. В нефтях Иллинойса ванадия $0,35 \div 1,5$ г/т, а в арабских - 9,52 $\div 51$ г/т. Зольный остаток нефтей

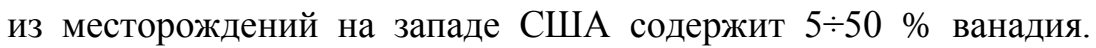
Максимальное содержание ванадия в нефти - 6 кг/т. Обогащенные $\mathrm{V}$ тяжелые нефти Венесуэльской провинции тяготеют на севере к рудному поясу Анд, где развиты гидротермальные месторождения ванадиевых и никелевых руд. В пределах Уральского рудного пояса нефти содержат до 569 г/т ванадия, а твердые 
битумы содержат ванадий до 1230 г/т [214,215]. Ванадий присутствует почти во всех месторождениях нефти Западного Казахстана (табл. 2.4).

В Бузачинской нефти содержится ванадия до 300г/т, а в Акбулакской нефти до 400 г/т [216]. Основная форма нахождения ванадия в нефтях Западного Казахстана - четырехвалентная, в виде ванадил иона [217]. Нами показано [44,218-220], что для нефти полуострова Бузачи и Мангышлак количество ванадия прямо пропорционально с количеством серы, асфалтенов и плотностью нефти.

$$
\begin{aligned}
& \mathrm{V}=-\mathbf{( 1 0 . 6 6} \pm \mathbf{1 5 . 9 4})+(\mathbf{8 8 . 3 1} \pm \mathbf{9 . 3 6}) \cdot \mathrm{S}, \mathrm{R}^{2}=\mathbf{0 . 9 5 7 8 6}, \mathrm{N}=10 \\
& V=(6.25 \pm 19.04)+(38.16+-5.38) \cdot A c \phi ., R^{2}=0.92875, N=10 \\
& \mathrm{~V}=-(\mathbf{1 8 0 2 . 8 2} \pm \mathbf{2 0 4 . 1 1})+(\mathbf{2 1 3 1 . 9 6} \pm \mathbf{2 2 6 . 3 4}) \cdot \text { Плот., } \\
& R^{2}=0.95776, N=10
\end{aligned}
$$

Для нефти Бузачи и Мангишлак с ростом глубины ее залегания содержание ванадия уменьшается.

$$
\begin{aligned}
& \mathrm{V}=(\mathbf{2 7 4 . 1 2 7 7 8} \pm \mathbf{2 0 . 8 5 3 8 4})-(\mathbf{2 8 . 1 2 5} \pm \mathbf{3 . 1 9 3}) \cdot \text { Глуб., } \\
& \mathbf{R}^{2}=\mathbf{0 . 9 5 7 7 4}, \mathrm{N}=10
\end{aligned}
$$

Однако для нефти месторождения Кара-Арна с ростом глубины ее залегания количество ванадия увеличивается:

$$
\begin{aligned}
& \mathrm{V}=(\text { 43.09 } \pm \text { 15.6775) }+(\text { (21.18 } \pm \text { 7.257) •Глуб., } \\
& \mathbf{R}^{2}=0.94601, \mathrm{~N}=3
\end{aligned}
$$

Такая же закономерность - увеличение с глубиной содержания ванадия установлена для изученной части многопластового месторождения нефти Сазанкурак. Такое распределение нефтей с разными свойствами внутри пластов подчиняется принципу гравитационной дифференциации, в соответствии с которыми ванадий со смолами и асфальтенами скапливается в нижних частях пласта.

Содержание никеля в земной коре $0,0058 \%$, а в ультраосновных породах $\left(1,2 \cdot 10^{-1} \%\right)$ примерно в 200 раз выше, чем в кислых 
$\left(8 \cdot 10^{-4} \%\right)$. Промышленные концентрации никеля обычно ассоциируют с базитгипербазитовыми магмами, связанными с подкоровыми очагами. Ему присущи сидерофильные и халькофильные свойства. В ультраосновных породах никель связан, как правило, с оливинами, содержащими $0,13-0,41 \% \mathrm{Ni}$, в которых он изоморфно замещает $\mathrm{Fe}$ и $\mathrm{Mg}$. При наличии в магме серы никель наряду с медью и железом, обособляется в виде сульфидов. В гидротермальном процессе совместно с кобальтом, мышьяком, серой, иногда и висмутом, ураном и серебром никель образует повышенные концентрации в виде арсенидов и сульфидов. Известно 45 минералов никеля. наиболее распространёнными являются: пентландит $(\mathrm{Fe}, \mathrm{Ni})_{9} \mathrm{~S}_{8}$, никелистый пирротин $(\mathrm{Fe}, \mathrm{Ni})_{7} \mathrm{~S}_{8}$, миллерит $\mathrm{NiS}$, ваэсит $\mathrm{NiS}_{2}$, никелин $\mathrm{NiAs}$, раммельсбергит $\mathrm{NiAs}_{2}$, хлоантит (NiCo)As $s_{2}$, герсдорфит (NiCo)AsS, гарниерит $(\mathrm{Ni}, \mathrm{Mg}) \mathrm{OSiO}_{2} \mathrm{H}_{2} \mathrm{O}$, непуит или ревдинскит $3(\mathrm{Ni}, \mathrm{Mg}) \mathrm{O} 2 \mathrm{SiO}_{2} \mathrm{H}_{2} \mathrm{O}$, непуит $12 \mathrm{NiO} 3 \mathrm{SiO}_{2} 2 \mathrm{H}_{2} \mathrm{O}$, водный арсенат никеля - аннабергит $\mathrm{Ni}_{3}\left(\mathrm{AsO}_{4}\right)_{2} 8 \mathrm{H}_{2} \mathrm{O}$

Отношение V/Ni является одним из основных параметров микроэлементного состава нефтей. Нефти резко различаются по величине $\mathrm{V} / \mathrm{Ni}$. Выделяют ванадиевые $(\mathrm{V}>\mathrm{Ni})$ и никелевые $(\mathrm{Ni}$ $>\mathrm{V})$ типы нефтей. Никелевые - легкие с низким содержанием серы, смол и асфальтенов и азотистыми и залегают на больших глубинах, а ванадиевые нефти являются тяжелыми, высокосмолистыми, сернистыми и низкоазотистыми $[34,38,44,45]$.

Нефтегазоносными бассейнами России и прилегающих территорий с доминированием никелевых соединений являются Пенжинский $(\mathrm{Ni} / \mathrm{V}=4.35), \quad$ Тимано-Печорский $\quad(\mathrm{Ni} / \mathrm{V}=2.1)$ и Анадырско-Наваринский (Ni/V=1.5). Для нефтегазоносных бассейнов Волго-Уральский $(\mathrm{Ni} / \mathrm{V}=0.33)$, Балтийский $(\mathrm{Ni} / \mathrm{V}=0.42)$, Лено-Тунгусский $(\mathrm{Ni} / \mathrm{V}=0.38)$, Охотский $(\mathrm{Ni} / \mathrm{V}=0.38)$, ЗападноСибирский $(\mathrm{Ni} / \mathrm{V}=0.67)$, Прикаспийский $(\mathrm{Ni} / \mathrm{V} \quad \mathrm{V} / \mathrm{Ni}=0.79)$ и Северо-Кавказский $(\mathrm{Ni} / \mathrm{V}=0.84)$ характерны высокие концентрации ванадия, а бассейны относятся к ванадиевому типу [214,215]. 
В нефти в свите Офисина в пределах Восточно-Венесуэльского бассейна среднее содержание никеля составляет 80 г/т. Обогащенные V, Ni тяжелые нефти Венесуэльской провинции тяготеют на севере к рудному поясу Анд, где развиты гидротермальные месторождения ванадиевых и никелевых руд. В пределах Уральского рудного пояса твердые битумы содержат никель до 1200 г/т.

Ni и V образуют металлопорфириновые комплексы.

В природных нефтях ванадилпорфирины, в основном, гомологи двух рядов: алкилзамещенных порфиринов (с различным суммарным числом атомов углерода в боковых заместителях порфиринового цикла) и порфиринов с дополнительным циклопентеновым кольцом. Их концентрации одного порядка.

\subsection{2. Роль металлопорфиринов ванадия и никеля в генезисе нефти}

Порфирины - самые распространенные пигменты в природе. К ним относятся гемоглобины, хлорофиллы, цитохромы и другие ферменты, они также присутствуют в выделениях животных, оперении птиц, раковинах моллюсков, нефти. Порфирины обнаружены не только в нефтях, но и в метеоритах в осадочных (изверженных) горных породах, минералах эндогенного происхождения, а также в асфальтитах, углях, торфе, сланцах, карбонатах, глубинных водах и т.д. 


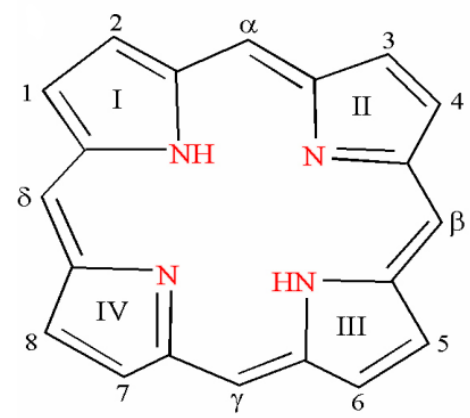

Рис. 2.2. Структурная формула порфина: I-IV- пиррольные кольца в ядре порфина, 1-8-атомы углерода ядра, $\alpha, \beta, \gamma$ и $\gamma$-атомы метиновых мостиков, соединяющих пиррольные кольца.

В молекуле любого порфирина имеется кольцо, которое составлено из четырех пиррольных фрагментов, которые соединены метиновыми мостиками в единую циклическую сопряженную систему, в основе которой лежит 16-членный макроцикл, включающий 4 атома азота (рис. 2.2). Родоначальник и простейший представитель порфиринов - порфин. В качестве заместителя могут выступать радикалы предельных и непредельных углеводородов, кислот, сложных эфиров, альдегидов, ароматических соединений и т.д. Эти порфирины называются свободными порфириновыми основаниями и в природе встречаются довольно редко [221,222].

В природе порфирины находятся в виде металлокомлексов, образующихся при замещении иминовых водородов металлом. Например, белковые молекулы, включающие комплексы порфирина с магнием, - это зеленый пигмент хлорофилл, без которого был бы невозможен фотосинтез; комплексы порфирина с двухвалентным железом - гемоглобины, обеспечивающие ткани кислородом [22]. Комплекс порфирина с никелем - ключевая часть кофермента F430, играющего важную роль в метаболизме метана у бактерий $[41,223,224]$. 


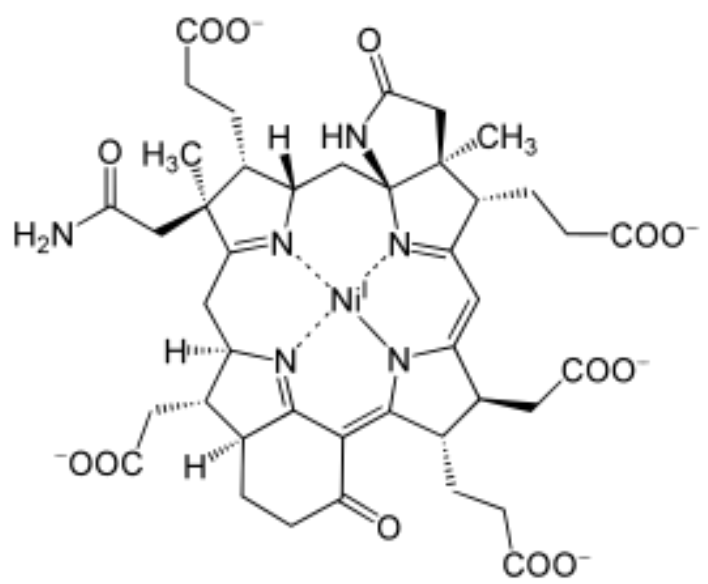

Рис.2.3 Кофермент F430.

Производные порфирина, содержащие кобальт, - витамин $\mathrm{B}_{12}$, недостача которого может спровоцировать анемию, нарушение функции мозга и нервной системы [221] (рис.2.3). Единственный из известных порфиринов живых организмов, содержащий медь, это ярко-красный пигмент турацин, обнаруженный только в перьях экзотической африканской птицы турако. 


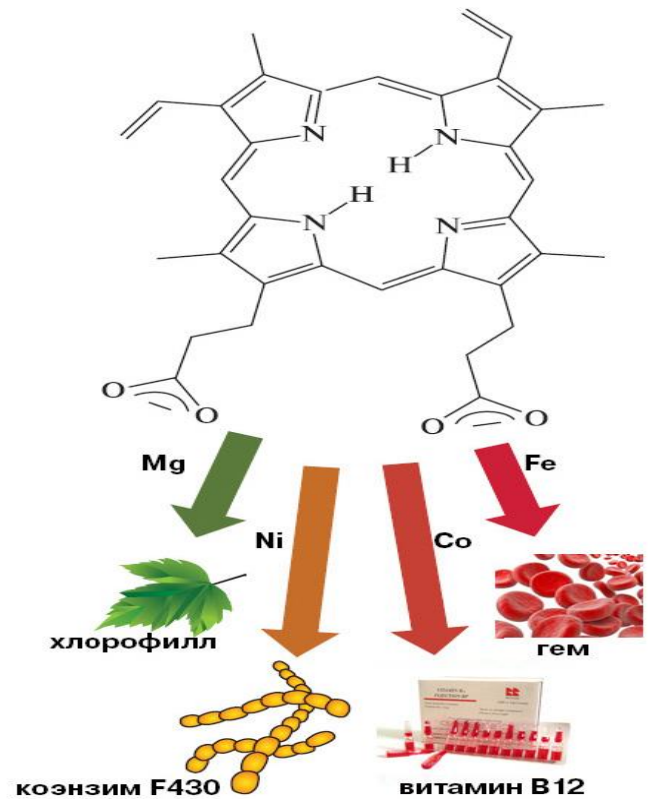

Рис. 2.4 Жизненно важные металлопорфириньл.

Согласно биогенной теории, металлопорфирины никеля и ванадия образовались в нефтях в процессе многоступенчатого замещения меди в ее комплексах и железа и магния в гемах и производных хлорофилла. Однако жизненно важные металлопорфирины, в том числе гемоглобин, как и хлорофилл, в составе нефти никогда не были обнаружены. Порфирины могут быть абиогенного происхождения: они синтезируются в соответствующих условиях и присутствуют в мантийных ксенолитах, а также входят в состав метеоритов.

Основными факторами, определяющими набор металлокомплексов геопорфиринов, являются, во-первых, количество и химические свойства металлов и, во-вторых, термодинамическая и кинематическая стабильность отдельных металлопорфиринов в геологических условиях. Так, в восстановительных условиях нефтеобразования возможно наличие в этих условиях катионов 
кобальта, скандия, марганца, цинка, железа, ванадия и никеля [42,222]. Из этих металлов наименьшим радиусом характеризуются катионы никеля и ванадия и, вследствие этого, они легко внедряются внутрь порфиринового макроцикла нефти. Катионы никеля и ванадия обладают наивысшей энергией стабилизации лигандов в плоскоквадратных и октаэдрических системах и наиболее благоприятными электронными конфигурациями для комплексообразования с тетрапирролами. То есть образование металлокомплексов порфиринов с никелем и ванадием выгодно с энергетической точки зрения [42].

В природных нефтях преобладают металлоэтиопорфирины и металло- дезоксофиллоэритроэтиопорфирины, содержащие изоциклическое кольцо, и с $\mathrm{Ni}^{2+}$ и $\mathrm{VO}^{2+}$ (рис. 2.5) в центре порфинового ядра. Металлопорфириновые комплексы присутствуют в природных битумах в количестве до 1 мг/100 г, а в высоковязких нефтях - до 20 мг/100 г нефти; установлено, что $40 \%$ ванадилпорфиринов сосредоточено в дисперсных частицах, а оставшаяся их часть (и никель-порфирины тоже) содержится в дисперсной среде. Кстати, оба вида металлопорфиринов в составе асфальтенов вносят значительный вклад в поверхностную активность нефтей. В сернистых нефтях больше порфиринов в виде ванадиевого комплекса, а в малосернистых, и особенно богатых азотом нефтях преобладают никелевые комплексы. Их концентрации одного порядка. Около 5-10 \% порфиринов нефти более конденсированные по отношению к алкилпорфиринам. Этим соединениям приписаны структуры бициклоалканопорфиринов, циклоалканомонобензопорфиринов и бензопорфиринов, 


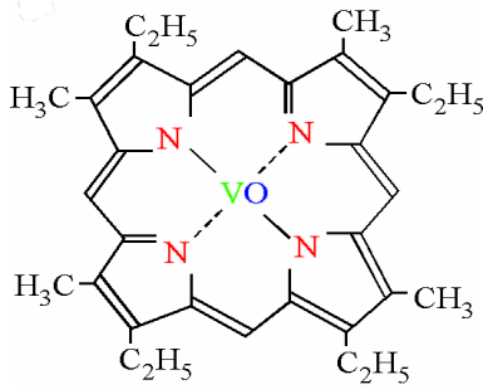

a

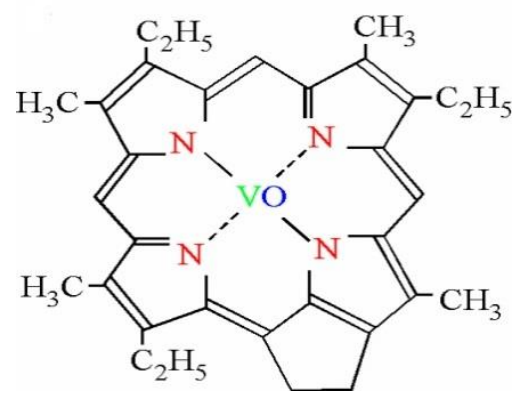

6

Рис. 2.5. Структурные формулы : а - этиопорфирина ванадия, б -дезоксофиллоэритропорфирина ванадия.

Следует особо отметить, что среди порфиринов биологического происхождения соединения с такими структурными особенностями не обнаружены. Металлопорфирины, имеющие в основе все пять перечисленных структур, представлены в нефти в виде непрерывных изобарических серий. Начальные их члены содержат обычно 5-7 алкильных атомов углерода в боковых заместителях порфинного цикла, конечные - до 25-30. Максимальное содержание в каждом ряду приходится обычно на гомологи с 10-13 алкильными углеродными атомами [212].

Порфириновые комплексы нефти обладают каталитической активностью. Они играют определенную роль в процессе генезиса нефти. В работе [225] установлено, что ванадилпорфириновые комплексы, синтезированные на основе нефтяных металлопорфириновых концентратов, стимулируют эпоксидирование в процессе оксигенирования олефинов. Показано, что выходы полученных оксиранов в зависимости от строения олефинов составляют 38-75\%. Предложен механизм эпоксидобразования при оксигенировании олефинов в присутствии ванадилпорфириновых комплексов, допускающий образование протонированного дикислородного адукта, в качестве промежуточного комплекса. В работе [226] показано, что в присутствии каталитической системы 
никель-порфириновый комплекс и бутиллития активно идет димеризация 1-бутена. Мы предполагаем, что никелопорфирины участвуют в образовании метана и других углеводородов, а также они играют определенную роль в реакциях диспропорционирования водорода в процессе генезиса нефти.

\subsection{2. Совместная роль геокосинергической системы $\mathrm{S}-\mathrm{N}-\mathrm{V}-\mathrm{Ni}$ в генезисе нефти}

Из представленного материала вырисовывается представление, что S-N-V-Ni действуют как интегрированная единая система. Следует отметить, что роль совместного действия серы и ванадия в генезисе нефти изучена в работах [38, 39]. Однако, как было показано нами, роль азота в генезисе нефти недостаточно изучена. Интересно изучение роли S-N-V-Ni геокосинергической системы в генезисе нефти.

Данные металлы, азот и сера как в свободном состоянии, так и в составе различных соединений, обладают ярко выраженной каталитической активностью в различных реакциях.

По количеству степеней окисления ванадий напоминает азот. Известны соединения ванадия с $+2,+3,+4$ и +5 степенями окисления. Ванадий обладает способностью растворять водород, при этом образовать гидрид с -3 степенью окисления. Соединения ванадия в степенях окисления +2 и +3 - сильные восстановители, в степени окисления +5 проявляют свойства окислителей [211]. В работе [277] было показано, что $\mathrm{V}_{2} \mathrm{O}_{5}$, нанесенный на непористый стекловолокнистый носитель, обладает высокой каталитической активностью в температурном интервале 170$200^{\circ} \mathrm{C}$, при окислении сероводорода до серы. Активность ванадиевых катализаторов растет с ростом содержания $\mathrm{V}_{2} \mathrm{O}_{5}$. Показано, что азот влияет на скорость и ход реакции Фишера-Тропша [198]. 
По количеству степеней окисления никель напоминает серу. Известны соединения никеля с $-1,+2,+3,+4$ степенях окисления. Никель обладает способностью растворять водород, при этом образовать гидрид с -2 степенью окисления [6]. В присутствии оксида хрома $(+3)$ и никеля из $\mathrm{CO}_{2}$ получается $\mathrm{CO}$, для реакции Фишера - Тропша [228]. В мантийных условиях при взаимодействии серы с $\mathrm{CH}_{4}$ образуются различные серосодержащие соединения и более высокомолекулярные углеводороды [38,39].

Пары $N i-N$ и $V-S$ по своим каталитическим свойствам являются своего рода антагонистами, т.е. в углеводородные системы их действия должны иметь разнонаправленный характер. $N i$ в свободном и связанном состояниях является катализатором и гидрирующим агентом, а $N$ и $\mathrm{NH}_{3}$ - восстановительными агентами. Ванадий, в частности, $V O$-порфирины являются катализаторами окисления углеводородов [229], что в присутствии серы может усиливать реакции окислительной конденсации. 


\section{ГЛАВА 3}

\section{1. Коллекторы и ловушки нефти}

Коллектором углеводородов называется горная порода, содержащая пустоты (поры, каверны или системы трещин) и способная вмещать и фильтровать флюиды, такие как нефть, газ и воду [230-233]. Следует отметить, что коллекторами нефти и газа являются как терригенные - алевриты, песчаники, алевролиты и некоторые глинистые породы, так и хемогенные и биохемогенные - известняки, мел и доломиты, а также смешанные породы. Таким образом, коллекторами служат пласты и выклинивающиеся залежи песков, песчаников, известняков и доломитов.

Для сохранения нефти и газа в коллекторе последний должен быть сверху и снизу изолирован непроницаемыми породами, обычно глинами. Ловушка нефти и газа - часть коллектора, условия залегания которого и взаимоотношения с экранирующими породами обеспечивают возможность накопления и длительного сохранения нефти или газа. Элементами ловушки являются коллектор нефти и газа, покрышка и экран. Таким образом, в основном коллекторы бывают терригенные и карбонатные. Менее значимы коллекторы, связанные с вулканогенно-осадочными, глинистыми и кристаллическими породами.

Терригенные коллекторы занимают первое место. На них приходится доля 58 \% мировых запасов нефти и 77 \% газа. Например, в Западно-Сибирском бассейне практически все запасы газа и нефти находятся в терригенных коллекторах. Карбонатные коллекторы занимают второе место. На них приходится доля $42 \%$ запасов нефти и $23 \%$ газа. 


\subsection{1. Глинистые породы}

Глины чрезвычайно широко распространены и имеют прямое отношение к процессам нефтегазообразования в земной коре. Предполагается возможное каталитическое действие глин в образовании углеводородов.Не менее важна роль глинистых пород как флюидоупоров («покрышек»), предотвращающих просачивание УВ к поверхности земли. Таким образом глинистые породы способствуют сохранению УВ. В осадочной оболочке Земли глинистым породам принадлежит ведущая роль (более $50 \%)$, а с учетом примеси в других породах, глинистые минералы составляют более $80 \%$ осадочных образований.

Глинистые породы - продукты выветривания, как механического, так и химического разрушения материнских минералов [234], таких как албит, ортоклаз и анортит:

$$
\begin{gathered}
\mathrm{Na}_{2} \mathrm{O} \bullet \mathrm{Al}_{2} \mathrm{O}_{3} \cdot 6 \mathrm{SiO}_{2}+2 \mathrm{H}_{2} \mathrm{O} \rightarrow \mathrm{Al}_{2} \mathrm{O}_{3} \bullet 6 \mathrm{SiO}_{2} \bullet \mathrm{H}_{2} \mathrm{O}+2 \mathrm{NaOH}, \\
\mathrm{K}_{2} \mathrm{O} \bullet \mathrm{Al}_{2} \mathrm{O}_{3} \cdot 6 \mathrm{SiO}_{2}+2 \mathrm{H}_{2} \mathrm{O} \rightarrow \mathrm{Al}_{2} \mathrm{O}_{3} \cdot 6 \mathrm{SiO}_{2} \bullet \mathrm{H}_{2} \mathrm{O}+2 \mathrm{KOH}, \\
\mathrm{CaO} \cdot \mathrm{Al}_{2} \mathrm{O}_{3} \cdot 6 \mathrm{SiO}_{2}+2 \mathrm{H}_{2} \mathrm{O} \rightarrow \mathrm{Al}_{2} \mathrm{O}_{3} \cdot 6 \mathrm{SiO}_{2} \cdot \mathrm{H}_{2} \mathrm{O}+\mathrm{Ca}(\mathrm{OH})_{2} \bullet
\end{gathered}
$$

Одним из основных агентов выветривания является вода. Растворяя химические элементы, насыщаясь углекислым газом, вода постепенно становится агрессивной и воздействует на горные породы как слабая кислота. Вначале в результате гидролиза разрушается кристаллическая структура минералов:

$$
\begin{gathered}
2 \mathrm{NaOH}+\mathrm{CO}_{2} \rightarrow \mathrm{Na}_{2} \mathrm{CO}_{3}+\mathrm{H}_{2} \mathrm{O} \\
2 \mathrm{KOH}+\mathrm{CO}_{2} \rightarrow \mathrm{K}_{2} \mathrm{CO}_{3}+\mathrm{H}_{2} \mathrm{O} \\
\mathrm{Ca}(\mathrm{OH})_{2}+\mathrm{CO}_{2} \rightarrow \mathrm{CaCO}_{3}+\mathrm{H}_{2} \mathrm{O} \\
\mathrm{Na}_{2} \mathrm{CO}_{3}+\mathrm{H}_{2} \mathrm{O}+\mathrm{CO}_{2} \rightarrow 2 \mathrm{NaHCO}_{3}, \\
\mathrm{~K}_{2} \mathrm{CO}_{3}+\mathrm{H}_{2} \mathrm{O}+\mathrm{CO}_{2} \rightarrow 2 \mathrm{KHCO}_{3}, \\
\mathrm{CaCO}_{3}+\mathrm{H}_{2} \mathrm{O}+\mathrm{CO}_{2} \rightarrow \mathrm{Ca}\left(\mathrm{HCO}_{3}\right)_{2} .
\end{gathered}
$$

Вода диссоциирует на ионы водорода и гидроксила, затем вступает в реакцию с кристаллическими веществами. Ионы заме- 
щают атомы в кристаллах или вступают с ними в реакцию, нарушается кристаллическая структура:

$$
\begin{gathered}
\mathrm{Al}_{2} \mathrm{O}_{3} \bullet 6 \mathrm{SiO}_{2} \bullet \mathrm{H}_{2} \mathrm{O} \rightarrow \mathrm{Al}_{2} \mathrm{O}_{3} \bullet 4 \mathrm{SiO}_{2} \bullet \mathrm{H}_{2} \mathrm{O}+2 \mathrm{SiO}_{2}, \\
\mathrm{Al}_{2} \mathrm{O}_{3} \bullet 6 \mathrm{SiO}_{2} \bullet \mathrm{H}_{2} \mathrm{O} \rightarrow \mathrm{Al}_{2} \mathrm{O}_{3} \cdot 2 \mathrm{SiO}_{2} \bullet \mathrm{H}_{2} \mathrm{O}+4 \mathrm{SiO}_{2}, \\
\mathrm{Al}_{2} \mathrm{O}_{3} \bullet 2 \mathrm{SiO}_{2} \bullet \mathrm{H}_{2} \mathrm{O}+\mathrm{H}_{2} \mathrm{O} \rightarrow \mathrm{Al}_{2} \mathrm{O}_{3} \bullet 2 \mathrm{SiO}_{2} \bullet 2 \mathrm{H}_{2} \mathrm{O} \\
\mathrm{SiO}_{2}+2 \mathrm{H}_{2} \mathrm{O} \rightarrow \mathrm{H}_{4} \mathrm{SiO}_{4} \\
\mathrm{Na}_{2} \mathrm{O} \bullet \mathrm{Al}_{2} \mathrm{O}_{3} \bullet 6 \mathrm{SiO}_{2}+2 \mathrm{CO}_{2}+11 \mathrm{H}_{2} \mathrm{O} \rightarrow \mathrm{Al}_{2} \mathrm{O}_{3} \bullet 2 \mathrm{SiO}_{2} \bullet 2 \mathrm{H}_{2} \mathrm{O}+ \\
2 \mathrm{NaHCO}_{3}+4 \mathrm{H}_{4} \mathrm{SiO}_{4} \cdot
\end{gathered}
$$

Кальций, магний, натрий и калий растворяются, а соединения алюминия и железа образуют гидроксиды. Процесс образования последних носит название гидратации. Кроме того, при химическом выветривании происходит окисление соединений двухвалентного железа в трехвалентное:

$$
\begin{aligned}
2 \mathrm{Fe}_{2} \mathrm{O}_{3}+3 \mathrm{H}_{2} \mathrm{O} & \rightarrow 2 \mathrm{Fe}_{2} \mathrm{O}_{3} \cdot 3 \mathrm{H}_{2} \mathrm{O} \\
2 \mathrm{FeS}_{2}+7 \mathrm{O}_{2}+2 \mathrm{H}_{2} \mathrm{O} & \rightarrow 2 \mathrm{FeSO}_{4}+2 \mathrm{H}_{2} \mathrm{SO}_{4} \\
4 \mathrm{FeSO}_{4}+2 \mathrm{H}_{2} \mathrm{SO}_{4}+\mathrm{O}_{2} & \rightarrow 2 \mathrm{Fe}_{2}\left(\mathrm{SO}_{4}\right)_{3}+2 \mathrm{H}_{2} \mathrm{O}
\end{aligned}
$$

При этом изменяется не только внутренняя структура горной породы, но ее цвет и физические свойства. В результате химического выветривания от твердой горной породы остается рыхлый глинистый материал, химический и минеральный составы которого зависят от первичного состава материнской породы и климата.

Под глинистыми породами подразумеваются различные глины, аргиллиты, глинистые сланцы, глинистые илы.

В глинистых породах могут находиться и не глинистые минералы: кварц, полевые шпаты, хлориты, силикаты, слюды, оксигидраты железа и алюминия, карбонаты, сульфаты, сульфиды, а также переотложенные обломки пород различного генезиса и элементы животных и растительных организмов.

Пластичные глины, состоящие из каолинита, слюды и гидрата окиси алюминия, называются огнеупорными. Цвет глин 
серый, красно- и желто-бурый, черный. Плотные глины, сцементированные кремнеземом, называются аргиллитами. Глины и аргиллиты служат хорошими «покрышками» для залежей нефти и газа.

Глины имеют самую высокую пористость и очень низкую проницаемость среди всех осадочных пород. Это обусловлено тем, что глины состоят из очень мелких частиц и каналы, соединяющие поры, сужаются настолько, что движение воды по ним затрудняется [235].

Наиболее часто встречаются глинистые минералы смектиты (монтмориллонит), гидрослюды (иллит), каолинит и хлориты.

Смектитовые глины набухают при контакте с водой. Связь между слоями глинистых частиц, имеющих кристаллическую структуру, у них слабее, чем у глин всех других типов. Вода может легко проникать между слоями и раздвигать их, глина набухает. Отдельные глинистые частицы могут расходиться настолько, что связь между ними исчезает (диспергирование).

Монтмориллонит - это широко распространённый глинистый минерал из группы смектитов подкласса слоистых силикатов. Химический состав непостоянный, сильно зависит от варьирующего содержания воды. По анализам чистых разностей устанавливаются следующие колебания (в \%): $\mathrm{SiO}_{2}-48-56, \mathrm{Al}_{2} \mathrm{O}_{3}-11-22$, $\mathrm{Fe}_{2} \mathrm{O}_{3}$ - 5 и более, $\mathrm{MgO}$ - 4-9, $\mathrm{CaO}$ - 0,8-3,5 и более, $\mathrm{H}_{2} \mathrm{O}$ - 12-24. Кроме того, иногда устанавливаются $\mathrm{K}_{2} \mathrm{O}, \mathrm{Na}_{2} \mathrm{O}$ и др.

Натриевый монтмориллонит называют бентонитом:

\section{$(\mathrm{Na}, \mathrm{Ca})_{0,33}(\mathrm{Al}, \mathrm{Mg})_{2}\left(\mathrm{Si}_{4} \mathrm{O}_{10}\right)(\mathrm{OH})_{2} \cdot \mathbf{n H}_{2} \mathrm{O}$}

Бентонит может увеличивать свой объем до 20 раз.

Иллитовые глины. Под воздействием высокой температуры и давления монтмориллонит претерпевает физические и химические изменения и превращается в иллит. Он не имеет раздвигающейся кристаллической решетки. Вода не может проникнуть в межслоевое пространство его кристаллов. Неустойчивость гли- 
нистых пород, содержащих иллит, приводит к увеличению диаметра ствола скважины. Каолинитовые и хлоритовые глины мало набухают при контакте с водой. Хлоритовые глины могут набухать сильнее, чем каолинитовые или иллитовые, но не так сильно, как смектитовые.

\subsection{2. Карбонатные породы}

Карбонатные породы составляют 15-20\% объема всех осадочных образований, содержат крупнейшие залежи нефти и газа. К карбонатным породам и осадкам относятся образования, сложенные до 50\% и более карбонатными минералами. Наиболее часто встречаются соединения кальцита и доломита. Это известняки и доломиты.

Известняки $\left(\mathrm{CaCO}_{3}\right)$ - карбонатные породы, состоящие на $50 \%$ и более из кальцита или арагонита. Известняки со значительным содержанием глин называют мергелями. Известняки, не содержащие примесей, имеют белый цвет.

Доломитами называют породы, сложенные на 50\% и более одноименным минералом $\mathrm{CaMg}\left(\mathrm{CO}_{3}\right)_{2}$. Кристаллическая решетка доломита в высокой степени упорядочена и образована замещением атомов Са в кальците через один на атом $\mathrm{Mg}$. В доломите место $\mathrm{Mg}^{2+}$ нередко занимает $\mathrm{Fe}^{2+}$.

\subsection{3. Вулканогенно - осадочные породы}

Вулканогенно-осадочными называются отложения, состоящие из продуктов вулканизма или из смеси их с терригенными, хемогенными, биогенными компонентами. Магматические источники вещества поставляют при вулканических извержениях огромные массы материала в жидком, твердом и газообразном состояниях. Этот материал затем перемещается на поверхности земли по общим законам седиментации и приобретает за счет этого 
черты осадочных отложений. Вулканогенные и вулканогенноосадочные породы представлены эффузивными породами (лавами, пемзами) и вулканогенно-осадочными (туфами, туфобрекчиями, туфопесчаниками).

Коллекторские свойства вулканогенных пород связаны часто с вторичным изменением пород, возникновением трещин.

\subsection{4. Кристаллические соляные породы}

Соляные породы являются чисто хемогенными образованиями, выпадающими в осадок в результате выпаривания и высокой концентрации солей в природных водах. Их называют эвапоритами. Они возникают в морских и континентальных условиях. Основными соляными породами являются сульфаты, хлориды, фосфаты, алюминистые, железистые, марганцевые породы. Главными минералами этих пород являются гипс $\left(\mathrm{CaSO}_{4} \cdot 2 \mathrm{H}_{2} \mathrm{O}\right)$, ангидрит $\left(\mathrm{CaSO}_{4}\right)$, мирабилит $\left(\mathrm{Na}_{2} \mathrm{SO}_{4} \bullet 10 \mathrm{H}_{2} \mathrm{O}\right)$ и т. д. из группы сульфатов; хлориды представлены сильвином(КС1), галитом $(\mathrm{NaCl})$, карналлитом $\left(\mathrm{KCl} \cdot \mathrm{MgCl}_{2} \bullet 6 \mathrm{H}_{2} \mathrm{O}\right)$,. Нитраты, бораты и сода встречаются гораздо реже.

В зоне катагенеза гипс переходит в ангидрит. При гипергенных процессах, напротив, ангидрит гидратируется и переходит в гипс, увеличиваясь в объеме на $60 \%$, что ведет к образованию текстур смятия. Гипс и ангидрит легко выщелачиваются подземными водами.

\subsection{5. Классификация коллекторов и свойства горных nород}

По строению коллекторы делятся на три типа:

1) гранулярные,

2) трещиноватые, 
3) смешанные.

Гранулярные коллекторы сложены песчано-алевритовыми породами, поровое пространство которых состоит из межзерновых полостей. Подобным строением порового пространства характеризуются также некоторые пласты известняков и доломитов.

Трещиноватые коллекторы сложены преимущественно карбонатами, поровое пространство образуется системой трещин. Участки коллектора между трещинами представляют собой плотные малопроницаемые нетрещиноватые массивы (блоки) пород, поровое пространство которых практически не участвует в процессах фильтрации.

Трещиноватые коллекторы смешанного типа встречаются чаще всего, поровое пространство включает как системы трещин, так и поровое пространство блоков, а также каверны и карст.

Трещиноватые коллекторы смешанного типа в зависимости от наличия в них пустот различного типа подразделяются на подклассы - трещиновато-пористые, трещиновато-каверновые, трещиновато-карстовые и т.д.

Около $60 \%$ запасов нефти в мире приурочено к песчаным пластам и песчаникам, $39 \%$ - к карбонатным отложениям, $1 \%$ - к выветренным метаморфическим и изверженным породам, что делает породы осадочного происхождения основными коллекторами нефти и газа.

Важнейшим свойством горных пород является их способность пропускать флюиды через себя, или, наоборот быть непроницаемыми для них. Эти свойства обусловлены пористостью (пустотностью) и проницаемостью пород.

Пористость горной породы - наличие в ней пор (пустот), характеризует способность горной породы вмещать жидкости и газы.

Проницаемость - способность горных пород пропускать флюиды, зависит от размера и конфигурации пор, что обусловлено 
размером зерен терригенных пород, плотностью укладки и взаимным расположением частиц, составом и типом цемента и др. Очень большое значение для проницаемости имеют трещины. Непроницаемые породы или флюидоупоры - это породы, которые препятствуют уходу нефти, газа и воды из коллектора. Они перекрывают коллектор сверху (в ловушках), но могут и замещать коллектор по простиранию, когда, например, глины замещают песчаники вверх по подъему пласта.

Флюидонасыщенность (или коэффициент насыщенности) определяется как отношение объема нефти (газа, воды) к объему пор.

Флюидоупоры могут не пропускать жидкость (нефть и воду), могут пропускать газ, который имеет меньшую вязкость.

По литологическому составу флюидоупоры представлены глинистыми, карбонатными, галогенными, сульфатными и смешанными типами пород. Наилучшие по качеству флюидоупоры это каменная соль и пластичные глины, так как в них нет трещин.

В каменной соли вследствие её пластичности нет открытых пустот и трещин, каналов фильтрации, поэтому она является прекрасным экраном на пути движения нефти и газа.

Основными физико-механическими свойствами горных пород являются плотность, прочность, упругость, пластичность, твердость и абразивность.

Плотность горных пород определяется как отношение их массы к единице объема ( $\mathrm{d}=\mathrm{m} / \mathrm{v}, \Gamma / \mathrm{cm}^{3}$, кг/л или т/ $\left.\mathrm{m}^{3}\right)$.

Плотность породообразующих минералов колеблется в широком диапазоне, зависит от химического состава и структу-

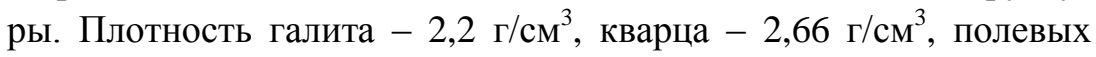

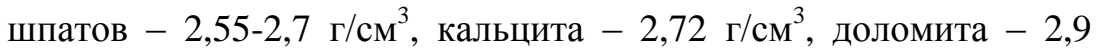

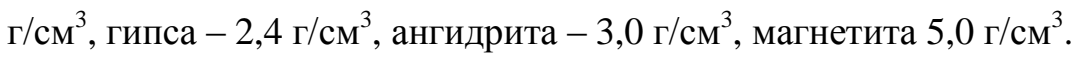

Прочность - это способность горных пород не разрушаться под дей-ствием приложенных к ним механических сил. Изме- 
ряется прочность напряжением (МПа), при котором порода разрушается.

Под упругостью понимают свойство горных пород восстанавливать свою форму без остаточной деформации после снятия напряжений.

Пластичность - это свойство горных пород сохранять остаточную деформацию, возникшую под воздействием внешних сил, после пре-кращения их действия. Горные породы по пластичности разделены на шесть категорий. К первой отнесены упругохрупкие породы. Ко второй-пятой категориям пластично-хрупкие породы, а шестую составляют высокопластичные горные породы.

Количественное (массовое) содержание в породе частиц различной величины принято называть механическим составом. От него зависят многие свойства пористой среды: проницаемость, пористость, удельная поверхность, капиллярные свойства и т. д. По механическому составу можно судить о геологических и палеогеографических условиях отложения пород залежи.

Размер частиц горных пород изменяется от коллоидных частиц до галечника и валунов. Однако исследования показывают, что механический состав большинства нефтесодержащих пород определяется в основном частицами в размерах от 1 до 0,01 мм. Так, размер частиц: крупнозернистых песков - 1-0,25 мм; мелкозернистых песков - 0,25-0,1 мм; алевролитов - 0,1-0,05 мм. Наряду с обычными зернистыми минералами в природе широко распространены глинистые и коллоидно-дисперсные минералы с размерами частиц меньше 0,1 мкм (0,001 мм). Значительное количество их содержится в глинах, лёссах и других породах. Тонкообломочные глинистые породы (пелиты), имеют размер частиц 0,01- 0,001 мM. 


\subsection{6. Классификация залежей нефти и газа}

Залежью нефти и газа называется естественное скопление этих флюидов в ловушке, обусловленной породой-коллектором под покрышкой из непроницаемых пород.

Известны более 200 класификаций залежей [230-233,236]. Так, в зависимости от рентабельности разработки, которая зависит от объема нефти и газа, характера насыщения пласта-коллектора и его глубины залегания, а также от других показателей, залежи подразделяются на промышленные и непромышленные.

В различных классификациях учитываются типы природных резервуаров и ловушек, распределение нефти, газа и воды в залежах и другие факторы.

По типу природного резервуара и ловушки обычно выделяют три основные группы залежей:

1) пластовые, среди которых различают пластовые сводовые и пластовые экранированные,

2) массивные,

3) литологически ограниченные со всех сторон.

Пластовые-сводовые залежи приурочены к ловушкам, представляющим собой антиклинальный изгиб пласта-резервуара. Формирование таких залежей происходит в результате движения флюидов по пластовому резервуару, ограниченному непроницаемыми породами в кровле и подошве пласта. Такие залежи распространены очень широко как в платформенных, так и в складчатых областях. Скопление нефти в массивном резервуаре - массивной залежью.

По составу флюидов залежи делятся на:

1) чисто нефтяные;

2) нефтяные с газовой шапкой;

3) нефтегазовые;

4) чисто газовые;

5) газовые с нефтяной оторочкой; 
6) газоконденсатные;

7) газоконденсатно-нефтяные и др.

Разделение флюидов в залежах происходит под воздействием гравитационного фактора в зависимости от величины их плотности. Верхнюю часть ловушки занимают газ и нефть, а вода подпирает их снизу, заполняя всю остальную часть резервуара. Газ, как более легкий, располагается над нефтью. Если нефти в ловушке значительно меньше, чем газа, то она подстилает газ, и такое скопление нефти называют нефтяной оторочкой газовой залежи. В тех случаях, когда газа меньше, чем нефти, его скопление в самой верхней части ловушки называется газовой шапкой.

Соответственно выделяются и границы раздела: водонефтяной контакт, газоводяной контакт, газонефтяной контакт. Контакт (граница) между нефтью и водой в песчаных породах с хорошими коллекторскими свойствами обычно резкий и четко выделяется на электрокаротажных диаграммах. Если пласты неоднородны и с низкими коллекторскими свойствами, то между нефтяной и водной частью располагается переходная зона. Она насыщена как нефтью, так и водой, и ее толщина составляет 10-15 м.

По углеводородному составу залежи подразделяются на 10 классов:

1) нефтяные,

2) газовые,

3) газоконденсатные,

4) эмульсионные,

5) нефтяные с газовой шапкой,

6) нефтяные с газоконденсатной шапкой,

7) газовые с нефтяной оторочкой,

8) газоконденсатные с нефтяной оторочкой,

9) эмульсионные с газовой шапкой,

10) эмульсионные с газоконденсатной шапкой.

По сложности геологического строения выделяют три группы залежей: 
1) простое,

2) сложное,

3) очень сложное.

Простого строения - однофазные залежи, связанные с ненарушенными или слабонарушенными структурами, продуктивные пласты характеризуются выдержанностью толщин и коллекторских свойств по площади и разрезу. Сложного строения одно- и двухфазные залежи, характеризующиеся невыдержанностью толщин и коллекторских свойств продуктивных пластов по площади и разрезу или наличием литологических замещений коллекторов непроницаемыми породами либо тектонических нарушений. Очень сложного строения - одно- и двухфазные залежи, характеризующиеся как наличием литологических замещений или тектонических нарушений, так и невыдержанностью толщин и коллекторских свойств продуктивных пластов, а также залежи сложного строения с тяжелыми нефтями.

По величине извлекаемых запасов:

1) уникальные - более 300 млн т нефти или 300 млрд м ${ }^{3}$ газа,

2) крупные - от 30 до 300 млн т нефти или от 30 до 300 млрд м ${ }^{3}$ газа;

3) средние - от 3 до 30 млн т нефти или от 3 до 30 млрд м ${ }^{3}$ газа;

4) мелкие - от 1 до 3 млн т нефти или от 1 до 3 млрд м ${ }^{3}$ газа;

5) очень мелкие - менее 1 млн т нефти, менее 1 млрд м газа

По значениям рабочих дебитов выделяют четыре класса залежей[4]:

1) высокодебитная - более 300 т/сут нефти или более 1 млн $\mathrm{M}^{3} /$ сут газа,

2) среднедебитная — от 10 до 100 т/сут нефти или от 100 тыс до 1 млн м³/сут газа, 
3) низкодебитная - от 2 до 10 т/сут нефти или от 20 тыс до 100 тыс м³ сут газа,

4) непромышленная - менее 2 т/сут нефти или менее 20 тыс $\mathrm{M}^{3} /$ сут газа.

По генетическому положению выделяют месторождения платформ и месторождения складчатых областей. Платформенные месторождения содержат 96 \% запасов нефти и $99 \%$ газа. Именно на платформах во всем мире сосредоточено большинство гигантских месторождений.

\section{2. Пластовые воды нефтегазовых месторождений}

Подземные воды нефтепродуктивного пласта играют важную роль в образовании месторождения нефти, накопления ее в ловушках. Движущаяся вода вытесняет нефть и газ из пласта и заставляет их передвигаться, переносит фракции нефти и газа в виде пузырьков или растворенном состоянии. Фракции нефти и газа скапливаются в ловушках, куполообразных структурах, ограниченных сверху водоупорами, или в ловушках более сложного образования: стратиграфических, тектонических, литологических и т. д. Подземная вода, залегающая совместно с углеводородами, непрерывно воздействует на них, приводя к количественным и качественным изменениям.

К водам залежей УВ относят воды, заполняющие коллекторы, принимающие участие в строении углеводородного месторождения и прилегающих участков земной коры.

В горных породах вода встречается в различной форме:

1) химически связанная,

2) физически связанная,

3) свободная,

4) в виде пара,

5) в твердом состоянии (лёд). 
Химически связанная вода - входит в состав минералов и является составной частью структуры кристаллических решеток. Например, в составе глин: $\mathrm{Al}_{2} \mathrm{O}_{3} \cdot 2 \mathrm{SiO}_{2} \mathrm{H}_{2} \mathrm{O}$ и гипса: $\mathrm{CaSO}_{4} \cdot 2 \mathrm{H}_{2} \mathrm{O}$.

Физически связанная вода - удерживается силами притяжения породы. Подразделяется на гигроскопическую, адсорбированную породами и прочно с ними связанную, и пленочную, обволакивающую частицу горной породы поверх гигроскопической

Свободная вода - представлена капиллярной водой, удерживаемой капиллярными силами, и гравитационной, способной свободно передвигаться по порам и пустотам породы под действием силы тяжести;

По пространственно-геологическому отношению к залежам УВ воды делятся на пластовые и посторонние.

Пластовые воды бывают:

1) краевые или контурные,

2) подошвенные,

3) промежуточные,

4) связанные (остаточные) - это капиллярные и защемленные внутри нефтегазового пласта воды.

Краевые, или контурные воды залегают в пониженных частях нефтяных пластов. Краевые воды называют также подошвенными, в которых верхняя часть пласта насыщена нефтью, а нижняя - краевой водой. В некоторых случаях контакт между нефтью и водой залегает выше подошвы пласта и вода является подошвенной на всем протяжении нефтяной залежи. К промежуточной воде относятся воды пластов или пропластков, залегающих в разрезе среди нефтяных пластов.

Посторонние (чуждые) воды бывают:

1) верхние относительно данного горизонта;

2) нижние относительно данного горизонта;

3) тектонические;

4) искусственно введенные в пласт. 
Верхними называются воды всех водоносных пластов, залегающих выше данного эксплуатационного пласта, а нижними воды всех пластов, залегающих ниже данного нефтяного пласта. Тектоническими называются воды, поступающие по дислокационным трещинам. Искусственно введенные воды поступают в пласт для поддержания давления путем законтурного и внутриконтурного заводнения. В первом случае они постепенно замещают краевую и подошвенную воды, а во втором образуют самостоятельный очаг или фронт воды. К искусственно введенным водам следует относить также воды, попавшие в пласты при бурении и ремонтных работах.

Для добычи нефти большое значение имеют физико-химические свойства пластовой воды, так как при внедрении воды в нефтяную залежь могут развиваться физико-химические процессы, приводящие к изменению количества отдельных солей в воде. Эти явления могут еще больше усиливаться при закачке в законтурную область пласта или непосредственно в нефтяную залежь поверхностных вод.

\section{3. Роль воды в миграции УВ и образования залежей нафтидов}

Гидрогеологические условие генерации, формирования и разрушения скоплений углеводородов происходят в среде, компонентом которой выступают подземные воды. Подземная гидросфера определяет размещение залежей УВ, способствует массо- и теплопереносу. Нефтиды до и после своего существования в виде залежей частично находятся в растворенном состоянии в подземных водах, химически и физически связаны с ними и представляют собой компонент их химического состава. Следует отметить, что в воде растворены основные органические вещества, из которых впоследствии в водной среде образуются нефтяные углеводороды и другие вещества, входящие в состав нефти. 
Генерация и формирование залежей нефтидов связаны с определенными геологическими и гидрологическими условиями в самой ловушке и вблизи них. Залежи нафтидов являются составной частью водонапорных систем. Гидрогеологические факторы создают условия, способствующие формированию и разрушению нефтяных и газовых скоплений.

Для образования залежей углеводородов необходима их миграция в структурные ловушки. Существуют следующие виды миграции углеводородов: миграция путем собственной диффузии, миграция УВ в водорастворенном состоянии, миграция УВ в жидкодисперсном состоянии, миграция нефти в виде газовых растворов. Так как подземные воды, нефть и газ - продукты общего процесса литогенеза, при котором происходит отделение твердой и жидкой фазы, то водная миграция УВ реальна. На каждой стадии литогенеза генерируются определенные углеводороды и формируются подземные воды определенного состава. Водная миграция углеводородных газов определяется их хорошей растворимостью, минерализацией подземных вод, температурой, давлением и глубиной. При высокой минерализации вод снижается растворимость углеводородных газов, а в глубинах с ростом температуры и давления растворимость увеличивается. Миграция в виде газовых растворов подтверждается высокой газонасыщенностью вод нефтяных и газовых месторождений.

Так как в составе водорастворенных органических веществах присутствуют поверхностно-активные веществ, например, жирные кислоты [4-6], то возможна и миграция нефти в жидкодисперсном состоянии, т.е. в виде тонкодисперсных эмульсий в воде. Выделение УВ из подземных вод может происходить также путем мембранного (фильтрационного) эффекта, т.е. разгрузки через поры водоупорной кровли в тонкодисперсном состоянии. Эти мелкие скопления в силу гравитационного фактора всплывая и сливаясь в крупных ловушках, также могут образовать залежь. 
Диффузия имеет большое значение при миграции УВ, так как она протекает постоянно при наличии перепада давлений или концентрации. Струйная миграция нефти и газа обеспечивает перенос флюидов после образования самостоятельной фазы в проницаемых водонасыщенных породах. Наряду с УВ газами в подземных водах присутствует много различных органических соединений, которые растворены в молекулярной, ионной и коллоидной формах. Органическим веществом наиболее обогащены приконтурные воды нефтяных и особенно газоконденсатных месторождений.

Кроме того, путями миграции флюидов являются системы разломов и трещин, биогермы и соляные диапировые структуры.

Трещиноватость, связанная с образованием разломов, создает вторичную проницаемость и пористость в хрупких породах, в связи с чем возникают благоприятные условия для вертикальной миграции флюидов. В зависимости от напряжения, нормального к плоскости разлома, природы этой плоскости и рассекаемых слоев разломы на разных этапах их геологической истории могли служить проводниками миграции флюидов, или флюидоупорами.

Флюиды движутся в направлении уменьшения свободной энергии. Величина свободной энергии определяется потенциальной энергией, которая уменьшается вниз по разрезу, и давлением, которое в нормально уплотненных осадочных отложениях обычно уменьшается вверх по разрезу. Центральные зоны мощных глинистых отложений с аномальным давлением флюидов служат барьерами для миграции. Флюиды мигрируют вверх и вниз относительно этих центральных зон.

Из кристаллических соляных пород, эвапоритовые отложения создают наиболее непроницаемые литологические преграды на пути миграции углеводородов.

Первичная миграция в карбонатных отложениях, содержащих не менее 10 \% глинистых минералов, и в некоторых меловых 
отложениях может осуществляться любым из четырех способов, в том числе, путем диффузии и в газовой фазе.

Дальность первичной миграции в тонкозернистых отложениях обычно невелика и определяется расстоянием до ближайшего проницаемого пласта. Вторичная миграция в непрерывных песчаных слоях происходит по трещинам, разломам, поверхностям несогласия. В проницаемых карбонатных отложениях она будет происходить до тех пор, пока на пути мигрирующих флюидов не возникнет препятствие в виде непроницаемого осадка. Главными проводниками миграции флюидов во время уплотнения осадков бассейна служат песчаники и поверхности несогласия.

Силы плавучести заставляют углеводороды подниматься к кровле коллектора, а капиллярные и электростатические силы отделяют углеводороды от воды на поверхности раздела грубозернистых и тонкозернистых пород, что приводит к аккумуляции нефти и газа.

Считается, что при созревании нефти в природном резервуаре происходят реакции, приводящие к диспропорции водорода и крекинга. При этом крупные молекулы, отдавая водород, увеличивают содержания низкомолекулярных парафинов. Крупные молекулы конденсируются в полициклические ароматические углеводороды, которые, в конечном счете, образуют в природном резервуаре асфальтиты, или пиробитумы. При созревании нефти процентное содержание нафтенов уменьшается по отношению к суммарному содержанию парафинов и ароматических углеводородов, причем уменьшается содержание тетра-, пента- и гексациклических нафтенов при увеличении содержания моноциклических нафтенов.

Следует отметить, что сперва УВ концентрируются в ловушках, а потом, после сформирования залежи, начинается обратный процесс их рассеивания из залежей. В этих противоположных процессах — концентрирования и рассеивания УВ, свою лепту 
имеют подземные воды. Так, при длительном контакте подземные воды с нефтяными и газовыми залежами, растворяют компоненты нефти и газа и выносят их на поверхность. Различают механическое или гидравлическое, физико-химическое, химическое и биологическое разрушения залежей. Если скорость движения вод велика и образуется наклон нефтеводяного или газоводяного контакта, то залежи могут разрушиться. Движущиеся воды увлекают и растворяют частицы углеводородов, могут перемещать залежь и выводить ее на дневную поверхность. Процесс разрушения залежей замедляется при низкой проницаемости коллекторов, вода обходит залежь, т.к. силы сцепления нефти и породы достаточно велики. Залежи нефти могут дегазироваться. Газ проходит в контурные воды и выносится. Нефть и газ могут выноситься водами и по тектоническим нарушениям. При интенсивном движении подземных вод газовые залежи могут быть разрушены в результате постепенного растворения и выноса газа.

Аэробное окисление УВ осуществляется растворенным в воде кислородом и сульфатами, Наибольшему воздействию кислорода подвергаются те залежи, которые расположены близко к зонам инфильтрации. Окисление залежей УВ идет также с помощью бактерий - десульфаторов. Окисление УВ может происходить также молекулярным кислородом при контакте с движущимися водами.

\section{4. Дисперсные системы нафтидов}

В рамках коллоидно-химического подхода нафтиды представляют собой многокомпонентную систему, из которой по агрегатному состоянию дисперсной среды и дисперсионной фазы можно получить девять дисперсных систем нафтенов (ДСН) (см. табл.1) [237,238]. 
Таблица 3.1.

Типь ДСН по агрегатному состоянию

дисперсной среды и дисперсионной фазы.

\begin{tabular}{|c|c|c|c|c|}
\hline № & $\begin{array}{l}\text { Дисперсная } \\
\text { среда }\end{array}$ & $\begin{array}{c}\text { Дисперсная } \\
\text { фаза }\end{array}$ & $\begin{array}{l}\text { Тип } \\
\text { ДСН }\end{array}$ & Примеры \\
\hline 1 & Газ & Газ & Воздух & Природный газ \\
\hline 2 & Газ & Жидкость & Туман & $\begin{array}{c}\text { Масляные туманы, } \\
\text { попутные газы }\end{array}$ \\
\hline 3 & Газ & Твердое & Аэрозоль & $\begin{array}{c}\text { Твердые продукты } \\
\text { неполного сгорания } \\
\text { топлива в выхлопных } \\
\text { газах, технический } \\
\text { углерод } \\
\end{array}$ \\
\hline 4 & Жидкость & Газ & $\begin{array}{c}\text { Газовые } \\
\text { эмульсии, } \\
\text { пены }\end{array}$ & $\begin{array}{c}\text { Жидкие НДС в процессе } \\
\text { нагревания или } \\
\text { барботажа, масла в } \\
\text { динамических условиях, } \\
\text { битумные пены } \\
\end{array}$ \\
\hline 5 & Жидкость & Жидкость & Эмульсии & Вода - нефть \\
\hline 6 & Жидкость & Твердое & $\begin{array}{l}\text { Золи, гели, } \\
\text { суспензии }\end{array}$ & $\begin{array}{c}\text { Среднедистиллятные } \\
\text { топлива, вакуумные } \\
\text { газойли, масляные } \\
\text { фракции, масла, } \\
\text { нефтяные остатки } \\
\text { (мазуты, гудроны, } \\
\text { полугудроны), битумы, } \\
\text { пеки }\end{array}$ \\
\hline 7 & Твердое & Газ & $\begin{array}{c}\text { Отвержден- } \\
\text { ные пены, } \\
\text { газогидраты }\end{array}$ & $\begin{array}{l}\text { Нефтяной кокс, } \\
\text { газогидраты }\end{array}$ \\
\hline 8 & Твердое & Жидкость & $\begin{array}{c}\text { Твердые } \\
\text { эмульсии }\end{array}$ & $\begin{array}{c}\text { Твердые углеводороды, } \\
\text { петролатум, гач }\end{array}$ \\
\hline 9 & Твердое & Твердое & $\begin{array}{c}\text { Твердые } \\
\text { дисперсные } \\
\text { структуры }\end{array}$ & $\begin{array}{c}\text { Нефтяной кокс, } \\
\text { углеродные волокна }\end{array}$ \\
\hline
\end{tabular}

Из представленных ДСН наибольший интерес представляют нефтяные эмульсии 


\section{5. Нефтяные эмульсии}

Эмульсией называют дисперсные системы двух малорастворимых или не растворимых друг в друге жидкостей, Одна из этих жидкостей диспергирована в другой в виде мелких капелек и называется дисперсной фазой. Дисперсная среда - это жидкость, в которой находится диспергированная жидкость. Существуют два основных типа эмульсий: прямые и обратные.

Прямые эмульсии, когда капли нефти являются дисперсной фазой и распределены в воде (полярная дисперсионная среда). Такие эмульсии называются «нефть в воде» или «масло в воде» и обозначаются Н/В или М/В. Обратные эмульсии, когда капельки воды являются дисперсной фазой и распределены в нефти (неполярная дисперсионная среда). Такие эмульсии называются «вода в нефти» или «вода в масле» и обозначаются В/Н или В/М.

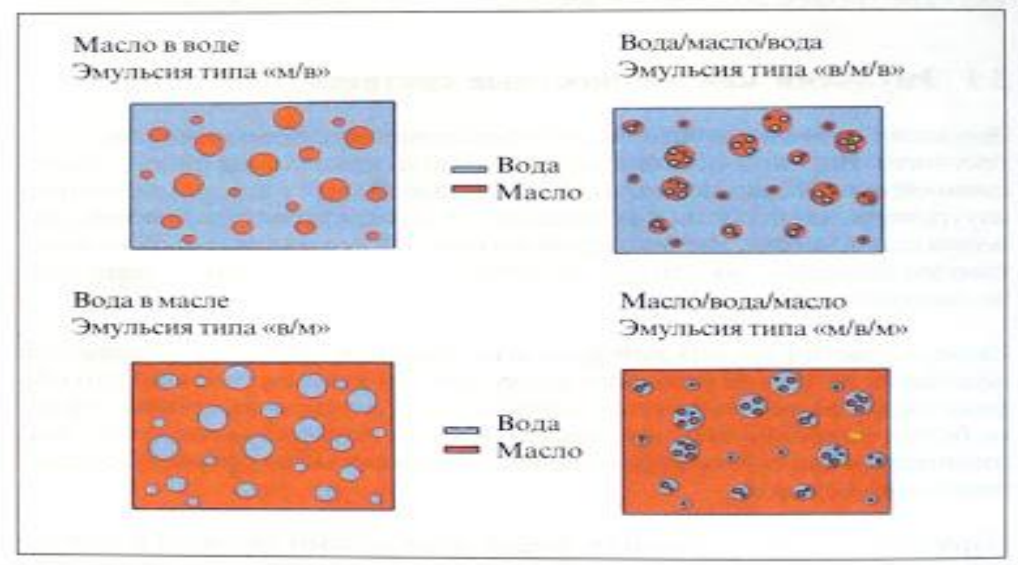

Рис. 3.1. Типы эмульский.

Эмульсии Н/В образуются в основном в процессе деэмульсации нефти, т.е. при разрушении обратных эмульсий. Нефтяные эмульсии прямого типа по сравнению с обратными эмульсиями, 
большей частью малоконцентрированные системы. В обратных эмульсиях содержание дисперсной фазы в нефти может колебаться до $80 \%$. Существует также смешанная или множественная эмульсия, когда в сравнительно крупных каплях воды могут находиться мелкие глобулы нефти, и, наоборот, в крупных каплях нефти находятся мелкие глобулы воды. Такие эмульсии обычно имеют повышенное содержание различных механических примесей. Образование водонефтяной эмульсии обусловлено рядом факторов, например, применение заводнения в качестве основного способа интенсификации притока нефти. Около $80 \%$ нефти добывается в настоящее время на месторождениях, где применяется закачка воды. Вода также может просачиваться в скважину из расположенных выше водоносных пластов, встречаться в самой нефтеносной породе.

Устойчивость эмульсии связана с ее температурой: водонефтяная эмульсия менее устойчива при высоких температурах. При этом уменьшается и ее вязкость. Более четко это проявляется в парафинистых нефтях. Можно констатировать, что теоретически водонефтяная эмульсия считается неустойчивой системой, стремящейся к расслоению, к образованию минимальной поверхности раздела фаз.

Известно,что на свойства поверхности раздела фаз сильное влияние оказывают растворенные и диспергированные в пластовой воде вещества, а также температура и $\mathrm{pH}$ сред. Энергия, затраченная на образование эмульсии, концентрируется на границе раздела фаз в виде свободной поверхностной энергии и называется поверхностным (или межфазным) натяжением(б). Капли жидкой дисперсной фазы при этом приобретают сферическую форму, т.к. сфера обладает наименьшей поверхностью при данном объеме:

Как показывает практика, из-за адсорбционных слоев на поверхности диспергированных частиц образуются устойчивые эмульсии. Адсорбционные слои препятствуют слиянию частиц и 
расслоению эмульсии. В их состав входят естественные нефтяные стабилизаторы (эмульгаторы): асфальтены, смолы и парафины, которые являются природными поверхностно-активными веществами (ПАВ)[239,240]. В образовании и стабилизации водонефтяных эмульсий важную роль играют нерастворимые твердые продукты, находящиеся в нефти в коллоидном состоянии. Так, асфальтены, микрокристаллы парафина, сульфид железа, а также механические примеси образуют на поверхности капель механически прочные оболочки, препятствующие их коалесценции. Все нефти образуют эмульсии, но способность их к эмульгированию далеко не одинакова.

Устойчивость эмульсий бывает кинетическая и агрегативная. Кинетическая устойчивость - это способность эмульсионной системы противостоять оседанию глобул дисперсной фазы под действием сил тяжести. Способность частиц дисперсной фазы сохранять свой первоначальный размер при столкновении друг с другом или с границей раздела фаз называется агрегативной устойчивостью.

Со временем увеличивается устойчивость большинства водонефтяных эмульсий. Так, при старении эмульсии слой эмульгатора на глобулах воды увеличивается, что приводит к повышению его механической прочности. Наличие прочной гидрофобной пленки приводит к тому, что не происходит коалесценция при столкновении таких глобул. Состав и свойства нефти и пластовой воды определяют тип эмульсии и особенность старения обратной эмульсии. Пластовая минерализованная вода, как известно, образует с нефтью более устойчивые и быстро стареющие эмульсии, чем пресная вода.

Минерализация и солевой состав водной фазы, несомненно, влияют на устойчивость и тип нефтяных эмульсий. Характер влияния зависит от состава нефтей и состояния асфальтенов в объеме нефти. Для многих нефтей повышение минерализации ведет к увеличению устойчивости эмульсии. Надо учитивать 
также соотношения главных ионов, особенно катионов. Известно, что нафтеновые кислоты нефтей, обладающие высокими поверхностноактивными свойствами, могут взаимодействовать с главными анионами и ионами $\mathrm{Al}^{+3}$ и $\mathrm{Fe}^{+3}$, находящимися в пластовых водах. При этом нафтенаты Na и К способствуют образованию эмульсий типа $\mathrm{H} / \mathrm{B}$, так как хорошо растворимы в воде и снижают устойчивость эмульсий типа $\mathrm{B} / \mathrm{H}$. В отличие от $\mathrm{Na}$ и К солей, нафтенаты $\mathrm{Ca}^{+2}, \mathrm{Mg}^{+2}, \mathrm{Al}^{+3}$ и $\mathrm{Fe}^{+3}$, обладают большей растворимостью в нефтяной фазе и сами по себе способны стабилизировать эмульсию обратного типа В/Н. Но в сочетании со смолистоасфальтеновым природным эмульгатором ослабляют его действие, вероятно, за счет снижения сил межмолекулярного взаимодействия молекул смолисто-асфальтеновых веществ между собой.

Известно, что при кислой и нейтральной реакциях воды адсорбционные слои на глобулах воды твердообразные и жесткие, соответственно, устойчивые эмульсии типа В/Н. Однако в слабощелочной среде формируются жидкообразные пленки, и этот слой способствует снижению устойчивости эмульсии. До сильнощелочной среды наблюдается резкое снижение межфазного натяжения и образование эмульсии типа (Н/B). В сильнощелочной среде возможно выпадение некоторых солей и гидроксидов калция и магния, которые сами могут являться стабилизаторами (эмульгаторами) эмульсий прямого или обратного типа.

Таким образом, содержание воды в нефтях весьма широко и может изменяться от десятых долей до $60 \%$ и выше. Так, в монодисперсных эмульсиях содержание воды может доходить до 74\%. О количестве воды в эмульсиях судят обычно по их цвету: эмульсии, содержащие до 10\% воды, по цвету не отличаются от безводной нефти; эмульсии, содержащие 15-20\% воды, имеют цвет от коричневого до желтого. Эмульсии, которые содержат более $25 \%$ воды, желтые. Наиболее стойкие эмульсии образуют высоковязкие нефти: повышенная вязкость дисперсионной среды 
препятствует столкновению глобул воды и их укрупнению. Поэтому маловязкие, малосмолистые, низкокислотные, легкие нефти при движении с нейтральными пластовыми водами образуют нестойкую эмульсию, а нефть с относительно небольшим содержанием воды образует более стойкие эмульсии [241-243]. С увеличением содержания воды стойкость эмульсий снижается.

С ростом объемной доли газовой фазы эмульгирование увеличивается лишь до определенных ее значений (газ способствует дроблению капель воды, перемешиванию). Дальнейшее возрастание доли газа в потоке уменьшает эмульгирование.

Вода в нефтях может быть в трех формах: растворенная, диспергированная и свободная. Содержание растворенной воды зависит в основном от химического состава нефти и нефтепродуктов и температуры. С повышением температуры растворимость воды увеличивается во всех углеводородах, а при снижении температуры растворимость воды в нефти уменьшается и вода может выделяться в виде дисперсных частиц, образуя В/H эмульсии. Наибольшей растворяющей способностью по отношению к воде обладают ароматические углеводороды. Чем выше содержание в нефти ароматических углеводородов, тем выше в ней растворимость воды.

\section{6. Газовые гидраты}

Природные газовые гидраты представляют собой метастабильный минерал, образование и разложение которого зависит от температуры, давления, химического состава газа и воды [244,245]. Гидраты природных газов образуются только при наличии в этих газах паров воды. Пары воды могут насыщать газ до определенного давления, равного давлению насыщенного водяного пара при данной температуре. Это предельное содержание водяных паров при данной температуре называется точкой росы. 
Если содержание водяных паров превышает этот предел, то начинается их конденсация, т. е. переход в жидкое состояние.

При контакте газа, имеющего высокое давление, с водным конденсатом обрауются гидраты. Гидрат метана - это супрамолекулярное соединение метана с водой $\left(4 \mathrm{CH}_{4} \cdot 23 \mathrm{H}_{2} \mathrm{O}\right)$. На рис. 3.2 приведена модель гидрата метана на молекулярном уровне.

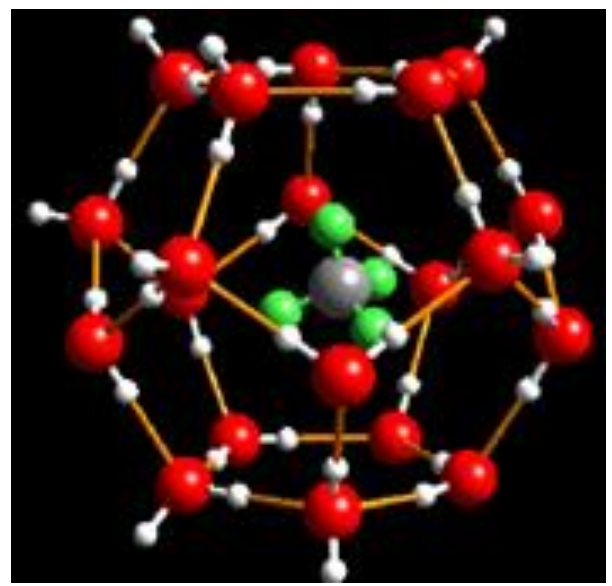

Рис.3.2. Модель гидрата метана

Вокруг молекулы метана образуется решетка молекул воды (льда). Соединение устойчиво при низкой температуре и повышенном давлении. Например, гидрат метана стабилен при нулевой температуре и давлении не менее 25 атм. Такое давление встречается на глубине океана около 250 м. Внешне газогидраты выглядят как грязноватый снег или желтовато-кремовые кристаллы, которые на поверхности стремительно испаряются. Если их поджечь, они горят жарким пламенем. При падении давления газогидраты разрушаются стремительно, выделяя огромный объем газа: из одного литра газогидрата получается почти 180 литров метана. 
При определённых термобарических условиях большинство природных газов - $\mathrm{CH}_{4}, \mathrm{C}_{2} \mathrm{H}_{6}, \mathrm{C}_{3} \mathrm{H}_{8}, \mathrm{CO}_{2}, \mathrm{~N}_{2}, \mathrm{H}_{2} \mathrm{~S}, \mathrm{Cl}_{2}$ изобутан и т. д., образуют гидраты.

Различают природные и техногенные газовые гидраты:

> Природные газовые гидраты могут образовывать скопления, имеющие в перспективе промышленное значение, а также находятся в рассеянном состоянии. Идентифицирован новый тип рассеянных газовых гидратов в зоне многолетнемерзлых пород - реликтовые газовые гидраты, сохранившиеся благодаря эффекту самоконсервации.

> Техногенные гидраты могут образовываться в системах добычи газа: в призабойной зоне, в стволе скважины, в шлейфах и внутрипромысловых коллекторах, в системах промысловой и заводской подготовки газа, а также в магистральных газотранспортных системах.

Благодаря своей клатратной структуре плотность гидрата ниже плотности воды и льда (для гидрата метана около 900 кг/м $\left.{ }^{3}\right)$. Кристаллогидраты обладают высоким электрическим сопротивлением, хорошо проводят звук и практически непроницаемы для свободных молекул воды и газа. Для них характерна аномально низкая теплопроводность (для гидрата метана при 273 К в пять раз ниже, чем у льда).

При повышении температуры и уменьшении давления гидрат разлагается на газ и воду с поглощением большого количества теплоты. Разложение гидрата в замкнутом объёме либо в пористой среде (естественные условия) приводит к значительному повышению давления. Способность газов образовать газогидраты авторами работы [246] использован как способ_утилизации попутного нефтяного газа путем перевода его в газогидрат в водонефтяной эмульсии. Так, водонефтяние эмульсии с объемным содержанием воды $75 \%$ выдерживают при температуре $-4{ }^{\circ} \mathrm{C}$ для предотвращения разделения эмульсии, подают в предварительно охлажденный до $-5{ }^{\circ} \mathrm{C}$ реактор совместно с попутным 
нефтяным газом, нагревают в реакторе до температуры в диапазоне от $1{ }^{\circ} \mathrm{C}$ до $3{ }^{\circ} \mathrm{C}$ с последующим быстрым снижением (в течение 30 мин) температуры в реакторе до $-10^{\circ} \mathrm{C}$ при давлении 4,3 атмосферы, при котором происходит рост газогидрата в эмульсии, сопровождающийся эффектом вытеснения образовавшегося газогидрата на поверхность обезвоженной нефти, при этом объемное содержание воды в эмульсии снижается с $75 \%$ до менее $5 \%$.

В работе [247] рассматриваются результаты исследования процесса гидратообразования природного газа в системах, состоящих в различных соотношениях из парафинистой нефти и дистиллированной воды.

Экспериментально установлено, что кривая равновесных условий в исследуемых системах, по сравнению с процессом гидратообразования данного газа в дистиллированной воде, смещается в область низких давлений и высоких температур. По результатам установлено, что с увеличением содержания воды более чем 40 мас. \% в эмульсиях степень превращения воды в гидрат в эмульсиях уменьшается. Таким образом, можно констатировать, что степень превращения воды в гидрат в эмульсиях может служить показателем ее стабильности.

Авторами работы [248] проведено комплексное исследование сырых нефтей разных месторождений Западной Сибири и их водных эмульсий, приготовленных в концентрации 50\%. Технически важные характеристики, такие как вязкость, плотность, температура застывания, групповой состав рассматривались для нефтей и эмульсий воды в нефти. В работе раздельно изучалось влияние состава нефтей на формирование нефтесмачиваемых гидратов. Эмульсии исследованы в модельном эксперименте нуклеации и образования газогидратов. Нефть ҮuT, из всех исследуемых, проявила положительную реакцию нуклеации и формирования газогидратов. В работе [249] исследованы структуры гидрата метана, полученного из водных эмульсий в маслах 
четырех типов - н-гептане и н-декане. Для стабилизации эмульсий воды в н-гептане и н-декане использовалось ПАВ Span 80. Синтез гидрата осуществляли двумя способами, а именно быстрым охлаждением эмульсии вода в масле, насыщенной метаном, и длительным изотермическим удержанием этой эмульсии. Показано, что различные способы приготовления гидратов могут приводить к образованию газовых гидратов с различной структурой. Полученные данные представляют интерес для понимания механизмов продвижения гидрата газа и могут дать новое представление о влиянии сырой нефти и поверхностноактивных веществ на зародышеобразование гидрата газа в системах вода-нефть-газ.

\section{7. Адсорбция углеводородов на глинистых минералах}

Гидросиликатная оболочка глины заполняется молекулами воды, способствуя ее первоначальному набуханию и гибридизации атома кислорода в составе связанной воды, что приводит к образованию слоя гидратной воды (которую также называют прочно связанной, координационно-связанной и которая представляет собой структуру на основе молекул воды, скрепленных водородными связями со сниженной полярностью). Далее, за счет вновь поступающих порций воды происходит формирование оболочки из молекул воды, скрепленных водородными связями, но обладающих меньшей прочностью, чем гидратная вода. Она придает глинистой пасте свойства геля, поэтому была названа гелевой. В технической литературе ее характеризуют качественно и называют - рыхлосвязанная вода (структура на основе молекул воды, скрепленных полярными водородными связями). Степень гидратации гидросиликатной оболочки глинистой частицы зависит от состава и структуры элементарных частиц глины, термодинамических условий существования глинистых отложений, а 
также от качества внутреннего наполнителя полимерного гидрата кремнезема. Это связано со свойствами пространственного заполнителя полимерного гидрата кремния, а также прохождения в гидросиликатной оболочке глины явления синерезис (старения). Синерезис приводит к дегидратации гидросиликатной оболочки. В соответствии с этим по глубине залегания, по времени формирования и условиям существования глины свойства глинистых отложений будут в значительной степени различаться по влажности и другим свойствам. Наличие у глины воды до состояния гидратного полимера обеспечивает ей состояние твердого тела. Поведение глинистых отложений в твердом состоянии будет определяться величиной горного давления. До некоторой, критической величины давления, гидратная вода будет обеспечивать глине свойства твердого тела, т. е. вещества атомного строения. При превышении величины давления более 100-200 МПа гидратная вода начнет приобретать металлические свойства. Подобные значения величины горного давления достигаются, напри-

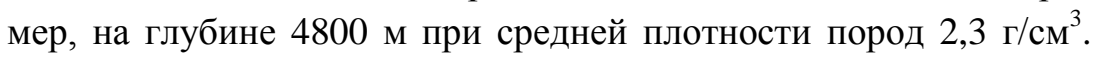
Несомненным будет тот факт, что подобные величины давлений должны реализовываться и при геотектонических процессах. Смачиваемость зависит от минерального состава внутрипоровой поверхности. На смачиваемость влияют уровень карбонатности и наличие глинистых минералов. Известно, что внутрипоровые поверхности выше $38 \%$ карбонатности более гидрофобны, и наоборот, образцы с низкой карбонатностью более гидрофильны. Высокое объемное содержание глины в гидрофильной породе также приводит к изменению смачиваемости. При этом адсорбция асфальтенов на глине в 4,5 раза меньше, чем на известняках. Но из-за большой удельной поверхности глины могут адсорбировать много асфальтенов. Для терригенных коллекторов гидрофобизация поверхности возрастает с появлением карбонатного цемента. В известняках, кроме обычной адсорбции молекул поверхностно-активных углеводородов, возможна их хемосорбция, 
которая сопровождается образованием на поверхности новых соединений, например, нафтенов кальция. Для коллекторов, содержащих газоконденсат, частичная гидрофобизация поверхности вероятна вследствие их «высушивания», выпадения конденсата в пористой среде при изменении первоначальных термодинамических условий в залежи. Степень адсорбции углеводородов зависит от типа глинистых минералов, дисперсности, состава тяжелых фракций нефти, уровня водонасыщенности, типа обменного катионного состава сырой нефти. Изначально глины в нормальных условиях гидрофильны. В результате адсорбции тяжелых фракций нефти (смолы и асфальтены), они гидрофобизуются. В результате образуется глинистоорганический комплекс, гидрофобный и очень устойчивый. Таким образом, поверхность стабилизируется относительно диспергирования и миграции. Это явление приводит к изменению смачиваемости и сопровождается снижением набухания, снижению адсорбции поверхностно-активных веществ при обработке пласта, способности к катионному обмену и сокращению площади поверхности. На адсорбцию углеводородов на глинистых минералах влияет следующее:

1. Тип глинистого минерала в составе породы и его количество. Монтмориллонит и вермикулит, обладающие высокой способностью к катионному обмену, будут мешать распространению закачки с использованием активных химических добавок. Присутствие в составе породы каолинита и тиллита снижают проницаемость вследствие низкой катионной активности и формы частиц, т.к. возникает диспергирование и миграция частиц;

2. Состав тяжелой фракции нефти, которая имеет большой молекулярный вес за счет наличия смол и асфальтенов. Взаимодействие с глинистыми частицами будет зависеть от диполярных видов ионов в асфальтенах и смолах и от крупной конденсационной структуры ароматического кольца. За укрепление ад- 
сорбционной связи между минералами и нефтью отвечает электронное взаимодействие с кислородом на поверхности;

3. Уровень водонасыщенности. Адсорбция на глинистых минералах снижается с ростом водонасыщенности, но не прекращается полностью. Если керн сухой, то адсорбция протекает быстрее. Адсорбция в данном случае протекает согласно изотерм Ленгмюра адсорбции первого типа. Но адсорбция асфальтенов в присутствии воды не стабилизирует глины;

4. Тип обменного катиона. Двухвалентные катионы вызывают большую адсорбционную активность по отношению к углеводородам;

5. Тип растворителя. Такие растворители, которые могут ионизировать асфальтены, как ниторобензин, вызывают большую адсорбцию, чем ароматические растворители, схожие по характеру с асфальтенами. Следовательно, также важна природа пластовой (сырой) нефти, действующей как текущий растворитель для тяжелых фракций. Таким образом, при взаимодействии глинистых минералов с тяжелыми фракциями нефти, поверхность покрывается адсорбированной углеводородной пленкой, причем это покрытие неравномерное. Данный слой стабилизирует поверхность, в результате которой снижается адсорбционная активность по отношению к воде, то есть поверхность становится устойчивой к воде, снижается набухание, способность к катионному обмену, снижается дисперсия (разрушение породы) и миграция частиц, адсорбция ПАВ. На терригенных образцах НовоУренгойского газоконденсатного месторождения исследовалась способность образцов керна, с данным комплексом глинистых минералов, адсорбировать индивидуальные УВ различного строения, такие как гексан, гептан, декан, изооктан, циклогексан, а также продукты переработки нефти. Адсорбция УВ зависит от их структуры. Из УВ с прямой углеродной цепью больше адсорбируются те, у кого длина углеродной цепи больше. Изомеризация соответствующего алкана приводит к уменьшению его доли в 
адсорбционном слое. Циклизация дополнительно снижает количество адсорбированных УВ. Причем наименьшей адсорбционной способностью обладает циклогексан, наибольшей -декан. Значительно больше адсорбируются породой продукты переработки нефти, но зависимость от содержания глинистых минералов-алюмосиликатов и их емкости катионного обмена остается той же, что и для индивидуальных УВ» [250]. 


\section{ГЛАВА 4}

\section{1. Методы обнаружения нефтяных залежей}

Обнаружение нефтяных залежей (Н3) тесно связано с надежностью и точностью поисково-разведочных метод. Экономическая эффективность добычи нефти зависит от качества и эффективности геологоразведочных работ, так как бурение одной разведочной скважины стоит миллионы долларов. Поэтому разработка быстрого и точного метода обнаружения нефтяных месторождений является эффективной и актуальной [251-257]. Несмотря на длительное и успешное развитие методов и методик поисково-разведочных работ, поиск нефтяных месторождений до сих пор остается чрезвычайно сложным и довольно рискованным занятием.

Методы поисков нефтяных месторождений подразделяют на:

1) геологические,

2) геофизические,

3) геохимические.

\subsection{1. Геологические методы}

Геологические методы поисков НЗ направлены на изучение поверхностных данных Земли. Поэтому геологи изучают и описывают поверхностные горные породы. Для того, чтобы узнать, что за породы залегают под современным поверхностным слоем осадочного материала, бурят небольшие шурфы или изучают фотографии, сделанные с самолета или даже из космоса. На таких снимках часто можно выявить поверхностные признаки глубинных структур, благоприятных для нефтегазонакопления. Для точного выявления глубины залегания НЗ используют геофизические методы. 
Бурение скважин применяется для создания границ залежей, а также для выявления масштабности залегания и интенсивности нефтегазоносных пластов. Еще в процессе бурения отбирают керн-цилиндрические образцы пород, залегающих на различной глубине. Анализ керна позволяет определить его нефтегазоностность. Однако по всей длине скважины керн отбирается лишь в исключительных случаях. Поэтому после завершения бурения обязательной процедурой является исследование скважины геофизическими методами. Самый широко используемый метод исследования мест залегания горючих природных ископаемых это электрокаротаж. Он основывается на опускании в проем специального устройства, которое позволяет определить электрические характеристики пород. Результаты измерений представляются в виде электрокаротажных диаграмм. Расшифровывая их, определяют глубины залегания проницаемых пластов с высоким электросопротивлением, что свидетельствует о наличии в них нефти. Практика электрокаротажа показала, что он надежно фиксирует нефтеносные пласты в песчано-глинистых породах, однако в карбонатных отложениях возможности электрокатоража ограничены. Поэтому применяют и другие методы исследования скважин: измерение температуры по разрезу скважины (термометрический метод), измерение скорости звука в породах (акустический метод), измерение естественной радиоактивности пород (радиометрический метод) и др.

\subsection{2. Геофизические исследования и виды поиска}

Геофизические исследования представляют собой методы изучения земных недр с помощью физических явлений. К таким исследованиям относятся:

1) сейсморазведка,

2) гравиразведка,

3) электроразведка, 
4) магниторазведка.

Сейсморазведка является одной из наиболее эффективных методов поиска НЗ. Она построена на применении закономерностей распределения в толще горных пород искусственных упругих волн. Звуковые волны могут быть сгенерированы различными способами. Например, на суше производят подрыв небольших зарядов или используют специальные виброгенераторы, а на море применяют пневмопушку. Общая идеалогия исследований такова. На поверхности (или вблизи нее) генерируется звуковая волна, которая распространяется вглубь недр расширяющейся сферой. На границах горных пород волны преломляются или отражаются, которые регистрируются на поверхности земли специальными приборами. Полученные данные записываются, обрабатываются и приводятся к единому формату. В результате получается довольно точное изображение геологической структуры в районе исследования.

Вплоть до начала двадцать первого века при сейсмических исследованиях Н3 проводилась исключительно двухмерная (2D) сейсмика, в результате которой можно было получить только плоское изображение среза земной коры. С развитием компьютерных технологий стала развиваться трехмерная (3D) сейсмика, которая гораздо информативнее, чем плоское изображение, которое получают при 2D сейсмике. Трехмерная сейсмика позволяет не только выявить перспективную геологическую структуру и оценить ее размер, но и помогает определить наиболее целесообразные точки для бурения скважин.

Гравиразведка основана на изучении изменения гравитационного поля или зависимость силы тяжести на земле от насыщенности горных веществ. Плотные горные породы могут влиять на гравитационное поле. Задачей данного исследования является определение места с достаточно невысокой силой тяжести. Так, породы, наполненные газом или нефтью, менее плотные, чем такие, которые содержат жидкость. Даже самые незна- 
чительные изменения в гравитационном поле могут указать на типы горных пород и насыщающие их флюиды, которые залегают глубоко в недрах Земли.

Электроразведка основана на изучении параметров постоянного или переменного электромагнитного поля. Поскольку разные породы и насыщающие их флюиды по-разному проводят электрический ток, изучая изменения электромагнитного поля, можно сделать определенные выводы о характере залегающих пород. Так, породы, насыщенные УВ, имеют невероятно низкую электропроводность. Таким образом, электроразведка НЗ опирается на разную электропроводность полезных ископаемых.

Магниторазведка изучает изменения магнитного поля. Осадочные породы, насыщенные нефтью, не обладают магнитными свойствами, в то время как магматические и метаморфические породы, не содержащие нефть, ими обладают. Таким образом, магниторазведка также может подсказать типы пород, залегающих в недрах.

\subsection{3. Геохимические методы}

Геохимические методы поиска НЗ основаны на выявлении интерпретации рассеяния химических элементов, которые создают ареалы вокруг месторождений вследствие миграции элементов в окружающих месторождение породах, почвах, водах и даже растениях.

Ареалы бывают:

1) открытые,

2) закрытые.

Открытый ареал выходит на поверхность, а закрытый находится на какой-либо глубине в толще пород.

Обнаружение ареалов на поверхности определяется выбором методики отбора, отработки и анализа проб, позволяющей установить контрастность аномалий относительно фоновых содержа- 
ний применительно к выбранному типу биохимического опробования.

По времени образования различают следующие ареалы рассеивания:

1) первичные (сингенетические),

2) вторичные (эпигенетические).

Итак, в зависимости от форм миграции, характера и способов образования ареалов и способов их выявления различают следующие геохимические методы поисков:

1) литогеохимический,

2) гидрогеохимический,

3) биогеохимический,

4) газовая съемка.

Литогеохимический - метод, основанный на опробовании коренных пород, почв, эллювия, делювия, аллювия.

Гидрогеохимический метод обнаружения НЗ основан на изучении состава подземных и поверхностных вод. Т.е. он основан на способности химических элементов переходить в раствор и мигрировать в природных водах, в результате чего возникают водные ареоалы рассеивания, характеризующиеся аномальным содержанием элементов и веществ. Водные ареалы и потоки рассеивания наблюдаются в подземных и поверхностных водах, дренирующих месторождения. Они являются вторичными ареалами, эпигенетическими, т.к. образуются за счёт разрушения месторождений.

Водные ареалы и гидрогеохимические методы имеют ниже приведенные преимущества

$>$ Миграция элементов в природных водах возможна на относительно большие расстояния, чем в твердом виде. Поэтому, с помощью гидрогеохимического метода можно обнаружить месторождение, залегающее на больших глубинах. Метод особенно эффективен в условиях расчленённого рельефа. 
$>$ Необходимые поисковые данные можно получить на основании анализа небольшого числа проб воды.

$>$ Гидрогеохимический метод особенно применим для поисков месторождений гидрогенных элементов.

Вопрос о наличии аномальных содержаний химических элементов решается путем сравнения полученных данных с фоновым содержанием для данной геохимической провинции.

Биогеологический метод основан на способности организмов отражать в химическом составе особенности среды обитания. В поисковых целях используют небольшое число видов растений и их частей, которые накапливают рудные элементы линейнопропорционально содержанию их в питающей среде.

Изменения биологических особенностей растений могут вызвать изменения химического состава почв и почвообразующих материнских пород Эти изменения могут выражаться в следующем:

1) В смене видового состава растительных ассоциаций и появления неспецифическых растений (биоиндикаторы). Бывает, что растения предпочитают почвы, обогащённые каким-либо элементом или избегают мест с повышенным содержанием химических элементов.

2) В появлении необычных форм обычных растений, изменений темпов их развития (угнетение или пышный рост), в появлении патологических изменений стеблей, листьев, цветов. Это симптоматические индикаторы.

Все эти моменты лежат в основе геоботанических методов поисков месторождений. Поскольку ярко выраженные изменения в растениях встречаются не часто, геоботанические методы имеют подчиненное значение. В большинстве же случаев никаких внешних проявлений в растениях не наблюдается. Тогда используют универсальный биогеохимический метод, при котором изучается не ботанический вид растений, а их химический состав (анализируется водяной отжим или зола растений). 
Так, в работе [ 251 ] показано, что между содержанием элементов в почвах и в прорастающих на них растениях существует достаточно точная корреляция.

Газовые методы основаны на использовании миграции газа, генетически связанного с полезным ископаемым. Суть прямого геохимического метода, которая в работе [255] названа «газовой съемкой», заключается в определении подпочвенных слоях содержания нефтяных углеводородов, продиффундировавших туда из залежей нефти или природного газа. Наличие углеводородов обнаруживается либо непосредственно путём анализа подпочвенного воздуха, либо посредством изучения продуктов их изменения или воздействия их на окружающие породы и воды или даже на микрофлору. Соответственно этому предлагаются прямые методы поисков нефти и газа:

1) газовый,

2) люминесцентно-битумонологический,

3) радиоактивная съемка,

4) бактериосъемка.

Газовые съемки состоят в распознавании существования УВ и других газов в образцах горных пород и подземных вод. Вокруг любых залежей нефти и газа находится аура рассеивания таких газов.

Возможны три варианта:

1) определение свободного газа;

2) определение сорбированного газа;

3) газодебитный метод.

Берутся пробы свободного или пробы сорбированного газа из пород с глубин 1,5-2,0 специальными газоотборниками по сетке или заданными профилями.

Люминесцентно-битумонологическая съемка основывается на том, что над залежами нефти в породе образуется большое количество битумов. Битумы определяют также экстракционным методом. 
Радиоактивная съемки выявляет понижение радиационного поля, которое обуславливают нефтяные залежи.

Бактериосъемка - определяется наличие бактерий, способных усваивать УВ.

\section{2. Биогеофизический и комбинированные методы поиска месторождений углеводородов}

Здесь будут обсуждаться работы активных участников форума «Глубинная нефть» и конференций Кудрявцевские Чтения.

В последнее время возрос интерес к методам, направленным на прямой поиск нефтяных залежей и основанных на регистрации эффектов (биогеофизических аномалий), вызванных не только рудными залежами, но и самой нефтяной залежью. К таким методам относится биогеофизический метод (БГФ-метод) [257]. В древние времена этот метод называли лозоходством, это явление было известно уже более 4000 лет назад. Оно сводится к тому, что у некоторых людей при прохождении над водоносными или рудными зонами наблюдается отклонение или вращение зажатой в руке вильчатой древесной ветки.

По определениям А.М. Андреева биогеофизический метод, судя по всему, является методом прямым и как те же дайки он позволяет не прогнозы выдавать, а непосредственно картировать залежи углеводородов в недрах с фантастической точностью и детальностью и по ряду признаков выделять в отражающих их аномалиях очаги разгрузки глубинных флюидов [258-262]. Автором с использованием нетрадиционных методов биолокации, в том числе электроразведки МПП [263] разработана технология поисков подземных вод в самых сложных условиях горных территорий и городской застройки.

А.М. Андреевым [264] констатируется, что спор о происхождении углеводородов сегодня уже не имеет никакого смысла, потому что результаты исследований большого числа месторож- 
дений УВ биогеофизическим методом (БГФ), а тем более с недавно разработанной спинорно-голографической технологией дистанционного зондирования космоснимков (СГТ ДЗ), не оставляют ни одного шанса органической гипотезе. По крайней мере, если речь идёт о масштабах месторождений. Они чётко и однозначно указывают на глубинный характер их формирования. Очевидно то, что месторождения углеводородные и рудные тесно взаимосвязаны между собой. Так что данные технологии не менее эффективны и для поисков рудных месторождений. СГТ ДЗ технология позволяет оперативно оценивать состояние действующих вулканов и указывать на новые возможные места их формирования, которыми могут стать, при наличии под ними достаточно обширных очагов разгрузки глубинных флюидов, места современных разгрузок термальных вод, а возможно и грязевых вулканов. Последнее следует изучить ещё дополнительно. На высокую готовность вулкана к извержению указывает большая площадь углеводородной аномалии под ним, приближающаяся к площади полной аномалии. При этом с каждой сотней и тысячью лет после извержения, судя по приведённым данным, площадь такой аномалии постепенно увеличивается.

Уникальные возможности биогеофизического метода, на примере опыта решения различных геофизических задач, неоднократно демонстрировались Тимурзиевым А.И. [265-270] на различных конференциях и форумах. А.И. Тимурзиевым [265-267] предлагается на основе современной технологии сейсморазведки $3 \mathrm{D}$, которая даёт возможность объемного изучения разломов, идентифицировать (локализовать) и откартировать каналы вертикальной разгрузки УВ. Установлено, что формирование залежей углеводородов на барьерах глубинного массопереноса связано с фильтрацией потоков флюидов, локализованных в вертикальных «сверхпроводящих» колоннах на телах горизонтальных сдвигов фундамента и на сводах растущих поднятий, обеспечивающих 
растяжение и раскрытие недр. Решение этих задач, по его мнению, подводит к прямому прогнозу нефтегазоносности недр.

Использование аэрокосмических исследований осуществлялось в работе [269,270] как в рамках системно-геодинамического дешифрирования материалов дистанционного зондирования, так и комплексной интерпретации геолого-геофизической, космической и топогеодезической информации на базе геоинформационной системы ArcGIS. Районы работ включают по результатам дешифрирования космоснимков и рельефа земной поверхности (метод анализа линеаментов) районов крупнейшие месторождения УВ северной, центральной и восточной части севера Западной Сибири. Установлено, что методы дистанционных и структурногеоморфологических исследований сродни методам сейсморазведки 2D и гравимагнитным построениям, выделяющим разломы преимущественно диагональной системы с доказанной сдвиговой кинематикой (сколовые сечения хрупкого разрушения вдоль площадок максимальных касательных напряжений). Доказано, что сейсморазведка 3D обеспечивает картирование разломов другого генетического типа и кинематики.

Авторы работ [270.271] в качестве исходных данных для прогноза использовали изображения изучаемой территории, полученные методами потенциальных геофизических полей, а также мультиспектрального сканирования и морфометрических измерений поверхности Земли, в результате обработки топокарт или зондирования поверхности Земли из космоса стереофотограмметрическими методами. Для целей тектонического и нефтегазогеологического районирования территории Нерутинской депрессии в работе [272] также использовались данные грави- и магнитометрический, космической, топогеодезической съемок территории совместно с результатами сейсмогеологического моделирования. Подготовка данных к анализу и анализ методами математической классификации выполнены средствами геоинформационной системы ArcGIS и сейсморазведки МOГT-3D. 
М.В. Багдасарова предлагает для поисков НЗ использовать геодинамические параметры, замеренные на поверхности. В работе [23] показано, что динамика геологической среды, выраженная в градиентах современных движений земной поверхности и изменчивости гравитационного поля во времени, сопряжена с изменчивостью флюидной системы, проявляющейся в изменении содержания гелия в попутном газе и изменениях плотности нефти в залежах, и этот процесс отражен в тепловом поле, подвижности поверхности Земли и может быть использован в поисковых целях. Таким образом, предлагаемая модель формирования нефтегазовых месторождений позволяет по-новому подойти к поискам и разведке углеводородных скоплений, используя геодинамические параметры, замеренные на поверхности. Так как скопления флюидов в литосфере и обогащение ими твердых пород реагируют на прохождение сейсмических волн, надо помимо повторных гравиметрических наблюдений и динамики разломных зон геодезическими методами провести и сейсмический мониторинг геологической среды.

Х.Г. Зинатов для прогнозирования залежей УВ предлагает применять тектонофизический анализ. В статье [58] рассматривается методология и предлагается методика прогнозирования и картирования очагов скрытой разгрузки в осадочный чехол и кристаллический фундамент земной коры Республики Татарстан глубинных геофлюидов, включая углеводороды, на основе дешифрирования на космических снимках структурных рисунков неотектонически активных парагенетичных дислокаций с последующей их неогеодинамической интерпретацией посредством тектонофизического анализа геолого-геофизической информации. На основе тектонофизического анализа геологической информации, полученной при дешифрировании космических снимков и в ходе наземных работ, в неотектонически активных орогенах Запада Северо-Американской плиты и Западного сегмента орогенической области Ближнего и Среднего Востока, разрабо- 
танные тектонические предпосылки рекомендованы для поисков месторождений неметаллов в Среднеараксинской впадине и на территориях современных и палеорогенов [274]. Применение тектонофизического анализа для прогнозирования залежей УВ расматривается также в работах [275,276]. Кроме того, по совокупности работ по усовершенствованию прогноза и поисков в основном месторождений неметаллических и некоторых металлических полезных ископаемых на территории Алданской провинции неметаллических полезных ископаемых, на основе применения тектонофизических методов к материалам дешифрирования космических снимков и ко всем материалам геолого-геофизическим данным об образования этих месторождений и рудопроявлений, которые были получены в результате наземных геолого-геофизических исследований, Зинатов Х.Г. выдвинул и обосновал положение о том, «что поля напряжений в силу своей природы (распределение сил, например, в точке среды), в отличие от других факторов рудообразования, являются именно движущей силой процессов рудообразования и необходимым условием их прохождения и наиболее полно соответствует - пониманию «фактора», как термина. По отношению к другим, не менее важным факторам эндогенного рудообразования неметаллов, поля напряжений, повидимому, как и для эндогенных месторождений металлов, являются ведущими факторами, и их игнорирование чревато упущением многих закономерностей формирования, месторождений различных, часто, парагенетичных видов полезных ископаемых, и, следовательно, возникновением неразрешимых трудностей при их прогнозе и поисках. Все факторы различные стороны сложных процессов минерало- и рудообразования, в которых роль полей напряжений может рассматриваться как спусковой механизм эндогенного рудообразования, завершающего трещинообразованием всю подготовительную часть рудообразования, которая начинается с накопления рудных компонентов в осадочном литогенезе и прогрессирует с метаморфи- 
ческой и/или метасоматической их мобилизацией» [277]. Данное положение о ведущей роли тетонодинамических полей напряжений при формировании месторождений и рудопроявлений твердых и горючих полезных ископаемых нашло своё подтверждение при усовершенствовании тектонических предпосылок прогноза и поисков месторождений неметаллических, полуметаллических и металлических полезных ископаемых, а так же лигнитов, битумов, нефти и газа на территориях не только минерагенических провинций неметаллических полезных ископаемых США и Ближнего и Среднего востока, но и на территориях нефтегазоносных бассейнов США и территории Волжско-Камского нефтегазового бассейна [274-277].

Н. Б. Шевченко с сотрудниками в работе [278] рассматривают вопросы, связанные с особенностями образования зон релаксации геодинамических напряжений (ЗРГН) и определили их потенциальную экологическую опасность. Обосновывается целесообразность применения для выявления ЗРГН экологически безвредного и более экономичного биолокационного метода. В статье [279] обосновывается новое направление геологоразведочных работ, направленных на открытие месторождений нефти и газа в породах фундамента. Авторами на основе геолого-геофизических критериев и по аналогии с месторождением "Белый Тигр" выделена нефтегазоперспективная зона для поиска месторождений нефти и газа в породах фундамента на Среднеазовском поднятии (акватория Азовского моря).

\section{3. Геоэкологические аспекты повышения нефтеотдачи пластов}

Для повышения нефтеотдачи в нефтеносный пласт закачивают воду под давлением. При вытеснении нефти водой из трещиновато-пористого пласта коллектора и из неоднородной среды, содержащей малопроницаемые включения, вода под дейст- 
вием гидродинамических сил стремится вытеснить нефть из хорошо проницаемых зон, она прорывается по высокопроницаемой среде или по трещинам, а малопроницаемые блоки, насыщенные нефтью, оказываются окруженными со всех сторон водой. В результате значительная часть пласта не охвачивается заводнением, площадной коэффициент охвата низок. При вытеснении нефти водой значительная часть нефти остается в пласте неизвлеченной [280]. Низкая нефтеотдача при заводнении, наряду с горно-геологическими условиями, связана с особенностями гидродинамики водонефтяной системы в пористой среде. Большая остаточная нефтенасыщенность служит причиной низкого коэффициента вытеснения.

При увеличении обводненности дебит уменьшается, что обусловлено уменьшением относительной проницаемости коллектора [281].

Для продления срока исчерпания природных запасов нефти и увеличения степени извлечения нефти из пластов, идет поиск новых высокоэффективных методов. Кроме широко применяющегося метода заводнения, начинают находить практическое применение физико-химические, термические, газовые, микробиологические и другие специальные методы увеличения нефтеотдачи пластов [282]. При использовании физико-химических методов в вытесняющую воду добавляют химреагенты, которые улучшают гидродинамические условия вытеснения. Так, при заводнении нефтяных пластов используют полимеры, углекислый газ, поверхностно-активные вещества (ПАВ), минеральные соли, спирты, мицеллярные растворы. Метод полимерного заводнения впервые был использован на месторождении Ниагара штата Кентукки, США [283]. Многочисленные лабораторные эксперименты по вытеснению нефти из кернов полимерными растворами, как правило, свидетельствуют о значительном увеличении (по сравнению с водой) коэффициента вытеснения. При добавке полимеров в закачиваемую воду происходит увеличение ее 
вязкости и уменьшение фазовой проницаемости. Снижение подвижности вытесняющей фазы приводит к повышению устойчивости процесса. В работе [284] рассмотрены перспективы широкомасштабного внедрения полимерного заводнения в свете новых представлений о механизме действия полимерных добавок к закачиваемой жидкости на снижение остаточной нефтенасыщенности. В качестве вытесняющего агента применяют также карбонизированную воду-водный раствор углекислого газа. Растворение $\mathrm{CO}_{2}$ в нефти снижает его вязкость и этим контролируется подвижность фаз, тем самым увеличивается коэффициент охвата. Углекислый газ уменьшает также поверхностное натяжение на границе раздела фаз. За счет этого снижается остаточная нефтенасыщенность и увеличивается коэффициент вытеснения. При добавлении ПАВ в воду происходит изменение характеристик капиллярной системы. Уменьшаются силы поверхностного натяжения на границе раздела фаз и увеличивается коэффициент вытеснения.

Используют также импульсное, волновое, ультразвуковое, вибро, и т.п. воздействия на скважины непосредственно при добыче нефти с созданием длительной депрессии в добывающих скважинах.

Имеющиеся данные свидетельствуют о том, что определенные вибрации, вызванные естественными сейсмическими явлениями или искусственными взрывами, изменили эксплуатационные характеристики нефтяных скважин на расстояния до 200 км от эпицентра. Эти изменения повлияли на соотношение добываемой воды и нефти: скорость добычи воды увеличилась из пласта, который находился примерно в промежуточной водонасыщенности, в то время как дебит нефти увеличился в обводненных пластах, которые были близки к остаточной нефтенасыщенности. Теоретические и полевые исследования явлений показывают [285], что вибрации могут существенно влиять на относительную проницаемость воды или нефти, которая, по-видимому, частично 
восстанавливается при насыщениях водой коллекторов, которые обычно препятствуют течению определенной фазы. Ключевую роль играют ультразвуковые колебания, генерируемые сейсмическими волнами в пласте, и это было подтверждено измерениями авторами работы [285] на месте во время вибростимуляции резервуаров.

Одним из перспективных направлений исследований в области повышения нефтеизвлечения из пластов является исследование влияния упругих колебаний на продуктивный пласт. Исследования по влиянию упругих колебаний на застойные зоны нефти в нефтяном пласте с целью повышения коэффициента нефтеизвлечения находятся на начальной стадии. В работе [286] теоретически и экспериментально исследовано влияние упругих колебаний различных частот на фильтрацию нефтеводяных смесей в призабойной и межскважинной зонах пласта. Показано, что как следствие, повышается производительность нефтяных скважин и коэффициент нефтеизвлечения на нефтяных месторождениях.

В статье [287] представлен способ повышения эффективности добычи высоковязкой нефти за счет совмещения метода парогравитационного дренажа с волновым воздействием на пласт. Рассмотрены процессы формирования в нагнетательной скважине стоячих волн и распространения энергии упругих колебаний в продуктивный пласт через стенку скважины. Приведены расчеты распределения амплитуды колебаний давления в продуктивном пласте на примере Ашальчинского месторождения. Установлено существование оптимальных значений частоты волнового воздействия на пласт, дающее возможность принимать решение о выборе режима воздействия и технических средств его реализации.

Участник форума «Альтернативная нефть» С.А. Ерилин для интенсификации добычи нефти и газа на поздней стадии разра- 
ботки месторождений предлагает комплекс «ГИДРОТАРАН» [288,289].

Насосный способ добычи нефти в комплексе с поддержанием пластового давления закачкой воды, и интенсификации вытеснения нефти водой, на большинстве нефтяных эксплуатируемых залежей, привело к критической ситуации: количество воды в добываемой продукции превысило 90\%, и продолжает расти. При этом достигаемый коэффициент извлечения нефти, в среднем, находится в пределах 0,15 - 0,3, или, благодаря дорогостоящим методам увеличения нефтеотдачи, достигает 0,4-0,5. Причина столь низкого коэффициента извлечения нефти и высокой обводненности продукции - в вынужденной откачке скважинными насосами воды вместе с нефтью и попыткой горизонтального вытеснения нефти водой из продуктивного пласта.

Бесконечное число исследований и попыток совместить импульсное, волновое, сейсмическое, ультразвуковое, вибро, и т.п. воздействие, периодически при капитальном ремонте скважин, или постоянное воздействие непосредственно при добыче нефти с созданием длительной депрессии в добывающих скважинах, т.е. - с насосным способом добычи, ни к чему хорошему не привели - это плохо совместимые методы. Все 70-90\% остаточных запасов нефти в залежи при насосной добыче нефти, отрезаны от добывающих скважин активно фильтрующейся водой в самых высокопроницаемых пропластках в пласте и конусом воды в прискважинной зоне, и фактически недоступны для вовлечения нефти в процесс добычи. Но, как только переходим от насосной добычи к безводной фонтанной добыче, т.е. воссоздаете условия безводного фонтанирования добывающих скважин и обеспечиваете непосредственно во время добычи нефти постоянную интенсификацию притока безводной нефти во все добывающие скважины импульсным депрессионно-репрессионным и волновым способом вызова безводного притока нефти, все волновые и т.п. методы воздействия на прискважинную зону добывающих 
скважин, межскважинное пространство, и на все запасы нефти в залежи начинают работать в полной мере.

«Гидротаран-добыча» Gidrotaran Oil Production - это безводная добыча нефти из добывающих скважин фонтанным способом, с компенсацией отбора нефти закачкой воды в нефтяной пласт через нагнетательные скважины и поддержанием пластового и забойного давления в добывающих скважинах, близким к гидростатическому давлению. Инициация и интенсификация притока нефти в добывающие скважины осуществляется управляемым в широком диапазоне, гидравлическим объемным, импульсным, депрессионно-репрессионным, волновым и микросейсмическим воздействием на прискважинную зону пласта и межскважинное пространство. Gidrotaran-impact способствует снижению вязкости нефти, перераспределению пластовой энергии вовлеченных и не вовлечённых в разработку зон пласта, перераспределению упругих напряжений породы коллектора от горного давления, горизонтальному выравниванию водо-нефтяного контакта, обеспечивает вертикальное вытеснение нефти водой на фоне гидравлического, волнового, микро-сейсмического (дополнительно к естественному волновому фону) воздействия подъемом водо-нефтяного контакта на 1-10 см/год, и горизонтальным вытеснением безводной нефти в добывающие скважины. Таким образом обеспечивается подвижность и доступность традиционных общих геологических запасов в режиме постоянной интенсификации переформирования залежи, консолидации запасов в купольных частях залежи, и их добыча с коэффициентом извлечения нефти до - 1,0. Downhole Device Gidrotaran, и новые подходы к добыче и разработке традиционных нефтяных залежей: - кратно повысят обеспеченность извлекаемыми запасами и обеспечат вторую жизнь старых нефтяных залежей; - существенно снизят технологический оборот воды и потребность в химических реагентах; - интенсифицируют и оптимизируют добычу нефти на скважинах с фонтанным способом эксплуатации; 
- обеспечат качественно новый технологический уровень при освоении новых нефтяных залежей, в том числе нерентабельных для насосной добычи; - в перспективе, обеспечат рентабельную добычу газа из газогидратов [289].

\section{4. Новый метод обнаружения нефтяных залежей}

Целью предлагаемого изобретения является повышение достоверности и точности поиска месторождения нефти. Ниже предоставляется суть нашего изобретения: «Способ обнаружения нефти» [290].

Обнаружение нефтяных месторождений путем отбора проб поверхностных вод, определение концентрации ванадия в образцах методом атомно-абсорбционной спектроскопии, анализ полученных данных и подтверждение местоположений нефтяного месторождения. Предлагается отказаться от сравнений с фоновыми концентрациями ванадия для поверхностных вод и считается целесообразным сравнение с ПДК.

В патенте РФ RU 2417387C2 [291] для определения количества никеля и ванадия, сопровождающего нефть, рекомендуется проводить отбор проб на судне в море как по глубине, так и по горизонтали. Если количество ванадия в морской воде в 3 раза превышает фоновое количество, это считается признаком наличия нефтяного месторождения в морском шельфе.

Известно, что количество ванадия в морской воде, то есть в океанской воде, составляет в основном 2,5 мкг/л, а в поверхностных водах оно варьируется в зависимости от геологических особенностей водосборного бассейна, режима питания реки, соотношения грунтовых вод и поверхностных потоков. Количество ванадия в поверхностных водах составляет 0,2-4,5 мкг/л. Например, в реке Волга составляет 2,8 мкг/л [292,293], а в реках Дагестана от 0,43 до 1,81 мкг/л [294]. Поэтому в качестве основы для расчетов неверно брать фоновую концентрацию ванадия. Мы 
рекомендуем, чтобы для поверхностных вод не сравнивать с фоновыми концентрациями содержания ванадия, мы находим, что правильно сравнивать с ПДК.

Определено содержание ванадия во всех водных бассейнах (речных бассейнах) Республики Армения. Пробы вод отбирались в одобренных постоянных мониторинговых створах в течение 8 лет. Средние значения концентрации ванадия приведены в таблице 4.1. В таблицах приведены только данные тех наблюдений и стволов, в которых содержание ванадия превышало ПДК, по крайней мере, в 10 раз.

На территории Республики Армения нефтяные месторождения были обнаружены в районе населенных пунктов ЕгвардБюрегаван-Аштарак, которая расположена между реками Раздан и Касах [295].

Таблииа 4.1.

\begin{tabular}{|c|c|c|c|}
\hline Река & $\begin{array}{l}\text { Номер } \\
\text { створа }\end{array}$ & $\begin{array}{c}\text { Расположение } \\
\text { наблюдательного поста }\end{array}$ & $\begin{array}{c}\text { Среднее } \\
\text { превышение } \\
\text { ванадия }\end{array}$ \\
\hline \multirow{6}{*}{ Аракс } & 25 & Перед с. Сурмалу & 11.6 \\
\hline & 26 & $\begin{array}{c}\text { Выше точки слива реки } \\
\text { Раздан }\end{array}$ & 11.8 \\
\hline & 27 & $\begin{array}{c}\text { Ниже точки слива реки } \\
\text { Раздан }\end{array}$ & 12.8 \\
\hline & 28 & 0.5 км ниже с. Армаш & 10.8 \\
\hline & 29 & 2 км южнее от г. Агарак & 11.9 \\
\hline & 30 & $\begin{array}{c}2.8 \text { км - юго-восток от } \\
\text { г.Агарак }\end{array}$ & 11.5 \\
\hline \multirow[t]{2}{*}{ Ахурян } & 33 & 0.8 км выше г. Гюмри & 11.2 \\
\hline & 34 & 5 км ниже г. Гюмри & 11 \\
\hline \multirow[t]{3}{*}{ Севджур } & 40 & $\begin{array}{l}10 \text { км южнее от } \\
\text { г.Вагаршапата }\end{array}$ & 17.5 \\
\hline & 41 & $\begin{array}{c}11 \text { км юго-восток от г. } \\
\text { Вагаршапата }\end{array}$ & 16.0 \\
\hline & 42 & 0.5 км ниже от с. Ранчпар & 13.6 \\
\hline
\end{tabular}




\begin{tabular}{|l|c|c|c|}
\hline \multirow{3}{*}{ Касах } & 45 & 1 км выше г Аштарак & 10.8 \\
\cline { 2 - 4 } & 46 & 3.5 км ниже г.Аштарак & 10.8 \\
\cline { 2 - 4 } & 47 & Устье & 11.0 \\
\hline \multirow{3}{*}{ Раздан } & 53 & 0.5 км ниже с. Аргел & 12.0 \\
\cline { 2 - 4 } & 54 & 0.5 км ниже ГЭС Арзни & 12.6 \\
\cline { 2 - 4 } & 55 & Около с. Дарбник & 15.5 \\
\cline { 2 - 4 } & 56 & Устье & 14.5 \\
\hline Масрик & 63 & Устье & 13.1 \\
\hline Карчахпюр & 67 & Устье & 10.2 \\
\hline Гаварагет & 78 & Устье & 19.6 \\
\hline Арпа & 85 & 0.5 км ниже Вайка & 10.0 \\
\hline \multirow{3}{*}{ Воротан } & 100 & 1 км выше г Сисиан & 22.8 \\
\cline { 2 - 4 } & 101 & 2 км ниже г.Сисиан & 23.6 \\
\cline { 2 - 4 } & 102 & 0.5 км ниже ГЭС Татев & 11.0 \\
\hline Горис & 106 & 3 км выше г.Горис & 12.8 \\
\cline { 2 - 4 } & 107 & 1.5 км ниже г.Горис & 18.8 \\
\hline
\end{tabular}

В воде, взятой из наблюдательного пункта 45 реки Касах (расположенного в этом месте на 1 км выше г. Аштарак), обнаружено среднее превышение ПДК ванадия в 10,6 раза, в воде, взятой из наблюдательного пункта 54 реки Раздан обнаружено среднее превышение ПДК ванадия в 12.2 раза. В районе Арташат-Масис-река Аракс (Арташатянская низменность), где также была обнаружена нефть [295], в районе рек Раздан-СевджурАракс, в пробах воды, взятых из точек наблюдения в створе реки Севджур (10 км к югу от г. Вагаршапата), - 41 (11 км к югу от Вагаршапата) и створа 42 (на 0,5 км ниже Ранчпара»), содержание ванадия превышало соответственно $18,16,8$ и 13,8 раза. На ствоpe 26 реки Аракс содержание ванадия превысило ПДК в 11,6 раза, а содержание ванадия в воде, взятой из створа 55 (около Дарбника), превысило ПДК в 15,8 раза. В таблице 4.1 все територии около наблюдательных постов рассматриваются как перспективные месторождения нефти. 
Исходя из вышеизложенного, применение этого изобретения позволит с большой точностью определить наличие нефтяных залежей в русле реки, особенно в труднодоступных горных районах. Предлагаемый способ является надежным и наименее затратным, чем современные геологоразведочные методы.

С начала 50 - ых до 90-ых годов прошлого века разные советские экспедиции выполнили много исследований по нефти и газу. За этот период специалисты пробурлили свыше 200 скважин. В Арарат-Арагацской впадине еще с советских времен были сконцентрированы геологические, геофизические и буровые работы по поискам нефти и газа. Буровую разведку усилили в 60-е годы прошлого столетия вдоль берега Аракса в регионе Армавир, тогдашнем Октемберянском районе, у границы с Турцией. Именно там пробурены самые глубокие, до 5 км, скважины. В 70-е годы в одной скважине, на берегу реки Аракс, получили небольшой выброс газа - выходил он всего несколько дней. В селе Вохчаберд на пути в Гарни был обнаружен очень небольшой запас нефти [295]. В то время в СССР были открыты крупные месторождения в Западной Сибири, Поволжье, Казахстане, Туркмении, что привело к тому, что пристального внимания этим месторождениям не уделили. Однако в результате разведовательных работ было открыто несколько артезанских скважин и источников минеральных вод, а также соль на окраине Еревана - в Аване.

К началу 2000-х нефть стала постепенно дорожать, что привело к интересу в разведке новых мест, в том числе и в Армении. Запасы нефти и голубого топлива в соседних странах дают повод думать, что в Армении они тоже есть. После провозглашения независимости поиски нефти и газа в Армении возобновились. Обнаружить драгоценные запасы нефти и газа последние 25 лет пытались местные и иностранные компании. За этот период были пробурены всего две такие скважины: одну - «Армяно-американская горнорудная компания» в 90-е, вторую - канадская «Теат Energy» в 2000-е. Потратив несколько миллионов долларов, 
компании свернули работы и уехали. Нефтяные компании, которые приходили на разведку, в основном ограничивались менее затратными геофизическими исследованиями.

Ирландская компания «Blackstairs Energy» провела геофизические исследования в Сюникской, Вайоц Дзорской и Гегаркуниской областях Армении. На границе с Нахичеванью зафиксирована перспективная на нефть структура. В 2008 году на основе договора между ирландской Blackstairs Energy, канадской компанией «Vangold Resources Limited» и правительством Армении была создана компания «Blackstairs Energy Armenia». Министерство энергетики и природных ресурсов Армении выдало компании «Blackstairs Energy Armenia» разрешение на проведение в 2015-16 годах геологохимические исследования по сейсмической разведке по поиску залежей нефти и газа. Стоимость проекта свыше 10 миллионов долларов США. Эта местность, названная в геологии как «центральная депрессия», расположена в центральной и южной районах Армении и включает в себя и часть озера Севан. Специалисты компании уверены, что залежи УВ могут быть обнаружены в бассейне озера Севан в прибрежных селах Айраванк, Цахкашен и Норадус. Следует отметить, что в 50-е годы у села Еранос, недалеко от города Мартуни из одной гидрогеологической разведочной скважины стала выходить не вода, а тяжелые фракции нефти (мазут) в небольших количествах, и до настоящего времени они понемногу выходят на поверхность у устья скважины. Наши данные также говорят в пользу того, что в акватории Севана может быть нефть [290]. Так как озеро Севан представляет ценнейший запас пресной воды, то у правительства Армении принципиальная позиция. Никакой добычи в акватории Севана разрешено не будет. «Если в результате разведывательных работ выяснится, что в недрах Армении есть газ или нефть, компания должна будет обратиться за дополнительной экспертизой для получения лицензии для бурения скважин на данной территории» [296]. 
«Армянская компания нефти и газа», 100\% акций которой принадлежит "Энергетической компании Раздана" (РазТЭС), владельцем которой, в свою очередь, является компания «Ташир Капитал» российского бизнесмена армянского происхождения Самвела Карапетяна, в 2015 году подала заявку на проведение геолого-разведовательных работ по поиску нефтяных и газовых месторождений. Компания намерена искать нефть и газ на севере Армении, в регионах Амасия, Ахурян и Ашоцк (Ширакская область), Туманян, Гугарк, Спитак, Степанаван, Ташир (Лорийская область), Иджеван, Дилижан, Ноемберян и Берд (Тавушская область). В общей сложности геологические исследования охватят территорию площадью 8775 кв. км - это почти треть территории всей Армении.

С 2013 по 2018 годы в Армении нефть и газ искала компания «Интеграл петролеум», которая принадлежит российскому ЗАО «Интеграл». Главный геолог компании Ю.Р. Каграманов, анализируя данные, полученные в советские времена в Арарат-Арагацской впадине (Араратской, Армавирской, Котайкской и Арагацотнской областей), компания в ходе разведки выделила и оконтурила 13 участков, перспективных с точки зрения месторождений нефти и газа, среди них - нефтяная залежь в 5 км от Еревана. Ими установлены запасы газа в 15 миллиардов кубометров, а также прогнозированы ресурсы газа до ста миллиардов кубометров [297].

Компания Armenian Cas and Power Enterhpisec Incorporated (AGAPE), которая официально зарегистрирована в Канаде (Монреаль), намерена провести в Армении геологоразведочные исследования на предмет выявления запасов нефти и газа. Работы по геологоразведке планируются провести в Вайоц Дзорской и Сюникской областях при помощи сейсмических вибраторов. В целях реализации проекта будут привлечены 4 сейсмических вибратора с глубиной в 16,5 метров, что незначительно скажется на окружающей среде. Тем более, что на данном этапе на 
перспективных участках могут быть проведены лишь поверхностные поиски [298].

Месторождения нефти и газа в Армении не исключены, но на большой глубине, как отмечают специалисты. Так, вероятность найти нефть и газ в Армении тоже не стоит недооценивать, считает крупный специалист Геворк Варосович Чилингарян (Джордж Чилингар). Но в Армении, горячится он, столько напортили неглубоким бурением, что теперь серьезных добытчиков не убедить сюда вложиться. Как уверен Джордж Чилингар, если ты пробурил пару неглубоких скважин и ничего не нашел, то это еще не повод утверждать об отсутствии углеводородов в этом месте. Бурить нужно неоднократно, и бурить нужно глубоко только тогда станет более или менее понятно, есть ли тут нефть или газ [299].

Нефть есть там, где ее нашли, считает Чилингар, и Таиланд это доказал. Там одна из американских компаний пробурила штук 20 скваэнин, все пустые, как на подбор, и собиралась уходить из страны. Тайский монарх очень переволновался - ведь если бы эти ушли, другие сунулись бы сюда не раньше, чем через полвека. Чилингар пошел к президенту этой компании - неизвестно, что он ему сказал, но компания осталась и все жсе нашла очень серьезные газовые месторождения.

В Армении нужно бурить минимум на пять километров, полагает Чилингар, приводя в поддержку своим словам мнение крупных российских ученых-нефтяников. И не надо бояться таких глубин - во многих местах есть и большие, в той же России. Арутюнян Альберт Вирабович. принимая механизм дегидратации серпентинизированных ультрабазитовых серпентинитов на различных глубинах земной коры, рассматривает глубину 5-13 км как основные нефтегазоносные структуры на территории Армении [27]. 


\section{ГЛАВА 5 \\ ЗАЛЕЖИ НЕФТЕЙ И НЕФТЬ КАК ФРАКТАЛЬНАЯ, ХОРОДИНАМИЧЕСКАЯ И ГЕОИНФОРМАЦИОННАЯ СИСТЕМА}

\section{1. Фрактальность нефтяных залежей и нефти 5.1.1.Фрактальные и дендритные структуры геологических объектов}

Понятие фрактала введено в научный обиход в 1975 году Бенуа Мандельбротом [330,301]. Фрактал - от латинского слова fractus, сломанный камень, расколотый, нерегулярная среда. Мандельброт предложил миру по существу новую, неэвклидову геометрию - негладких, шероховатых, зазубренных, изъеденных ходами и отверстиями, шершавых и т.п. объектов. Мандельброт поясняет понятие фрактала как некоего образования, самоподобного или самоаффинного в том или ином смысле.

Надо отметить, что теория фракталов произвела революцию не только в геометрии, но и в физике, химии, геологии, биологии. Фрактальные алгоритмы нашли применение и в информационных технологиях, например, для синтеза трехмерных компьютерных изображений природных ландшафтов, для сжатия (компрессии) данных.

Фрактальными объектами называются те объекты, которые обладают свойствами самоподобия, или масштабной инвариантности. Самоподобными могут быть некоторые фрагменты системы, структуры которых повторяются в при разных масштабах. Простейшие фракталы, такие, как «канторова пыль», «снежинка Коха», «ковер и губка Серпинского», «кривые дракона» и «кривые Пеано и Гильберта», обладают регулярной, геометрически правильной, структурой. Каждый фрагмент такого геометрически правильного фрактала в точности повторяет всю конструкцию 
системы в целом. Оказалось, что даже простейшие из фракталов - геометрически самоподобные фракталы - обладают непривычными свойствами. Например, «снежинка Коха» обладает периметром бесконечной длины, хотя ограничивает конечную площадь. Кроме того, она такая «колючая», что ни в одной точке контура к ней нельзя провести касательную (рис. 5.1). Примерами случайных фракталов могут служить береговые линии, очертания некоторых государственных границ, поры в хлебе и зрелых сырах, границы доменов и зерен в кристаллах и так далее. Принято различать регулярные и нерегулярные фракталы, из которых первые являются плодом воображения, подобным кривой Коха, а вторые - продуктом природы или деятельности человека. Нерегулярные фракталы в отличие от регулярных сохраняют способность к самоподобию в ограниченных пределах, определяемых реальными размерами системы.

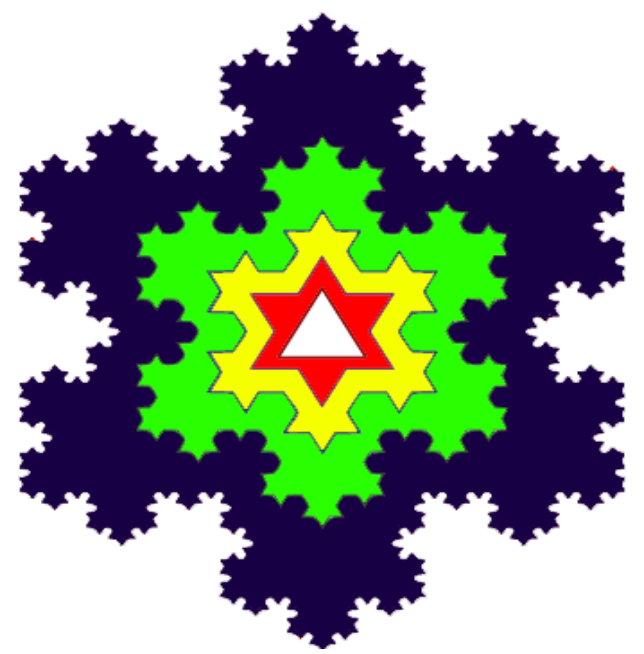

Рис. 5.1. Снежинка Коха.

Для характеристики фрактальных структур принято использовать термин, так называемая фрактальная размерность. Фрак- 
тальная размерность (D)- дробная размерность (от лат.: fragere ломать, разбивать, раздроблять), являющаяся характеристикой неустойчивого, хаотического поведения систем (сред). Последняя показывает степень заполненности пространства объектом или структурой. Чтобы произвести такую оценку, объект следует разбить на элементы, число которых $\mathrm{N}$ будет тем больше, чем меньше размер каждого элемента (n). В общем случае справедливо уравнение $\mathrm{N}=(1 / \mathrm{n}) \mathrm{D}$. В отличие от обычных геометрических образов - точка, линия, квадрат, куб, имеющих целочисленную размерность (0, 1, 2 и 3 соответственно), фрактальные структуры имеют нецелочисленную размерность. Фрактальная размерность «канторовой пыли» - фрактала, образующегося при дроблении линии до совокупности точек - $0<\mathrm{D}<1$. Фрактальная размерность «толстой линии» - фрактала, образующегося при дроблении отрезка, описывается соотношением $1<\mathrm{D}<2$. Фрактальная размерность «толстой плоскости» - $2<\mathrm{D}<3$. Фрактальная размерность объекта, образующегося при фрактальном преобразовании объемных структур, - $3<\mathrm{D}<4$. Так, для кривой Коха $\mathrm{D}=$ $\lg 4 / \lg 3=1,2618$. Фрактальная размерность снежинки равна 1,71 , то есть, как и кривая Коха, она занимает промежуточное положение между одно- и двумерными объектами.

До появления термина «фракталы» в минералогии и потом и в химии употребляли термин «дендрит» и «дендритные формы».

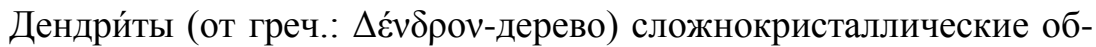
разования древовидной ветвящейся структуры. Ещё в 1774 г, два века назад, прежде чем в науке появились фракталы, Вернер упоминал «дендритные формы» минералов.

Дендрит представляет собой ветвящееся и расходящееся в стороны образование, возникающее при ускоренной или стеснённой кристаллизации в неравновесных условиях, когда кристалл расщепляется по определённым законам [302,303]. Они ветвятся и разрастаются в разные стороны подобно дереву. Процесс образования дендрита принято называть дендритным ростом. В про- 
цессе дендритного развития объекта кристаллографическая закономерность изначального кристалла утрачивается по мере его роста. Дендриты могут быть трёхмерными объёмными (в открытых пустотах) или плоскими двумерными (если растут в тонких трещинах горных пород). В качестве примера дендритов можно привести ледяные узоры на оконном стекле, снежинки и живописные окислы марганца, имеющие вид деревьев в пейзажных халцедонах и в тонких трещинах розового родонита В зонах окисления рудных месторождений самородная медь, серебро и золото имеют ветвистые дендридные формы, а самородный висмут и ряд сульфидов образуют решётчатые дендриты. Для барита, малахита и многих других минералов, например, «пещерные цветы» арагонита и кальцита в карстовых пещерах известны почковидные или кораллообразные дендриты. Дендриты как специфический продукт кристаллизации из растворов, несомненно, обладают фрактальными свойствами, хотя этими свойствами обладают фактически любые сложные продукты природы и человеческой деятельности [304].

\subsection{2. Фрактальность нефтяных месторождений, вмещцищих коллекторов и нефть}

Фрактальная самоподобность, которая сохраняет свою структуру на разных уровнях масштабирования, характерна для множества реальных систем, в том числе для объектов нефтяных месторождений, вмещающих коллекторов и самой нефти.

В работах [305,306] Запивалов и сотр. для контроля самоорганизации и управления сбалансированной разработки нефтяных месторождений и существенного увеличения коэффициента извлечения нефти и газа предлагают использовать фрактальное и наноразмерное моделирование нефтегазовых залежей. На основе анализа различных объектов терригенных отложений пашийского (Д) и кыновского (Д $)$ горизонтов верхнего девона 7 блоков 
Миннибаевской площади и 21 площади Ромашкинского месторождения в работах [307,308] выявлена фрактальная структура для объекта горизонтов Д 0 , Д 1 Ромашкинского месторождения. Показано, что Миннибаевская площадь является самоподобнымфрактальным объектом. Мальшаковым оценена фрактальная размерность скоплений залежей углеводородов, для трехмерного случая. Показано, что фрактальная размерность залежей равна 2.40-2.54. На основе теории перколяции обоснован закон распределения залежей по величине запасов [309].

Нефти, помимо углерода и водорода, содержат также гетероэлементы и, прежде всего, N, S, O, Ni и V. Концентрации этих металлов (V и $\mathrm{Ni}$ ) в нефти отдельных месторождений столь значительны, что оказываются вполне сопоставимыми с содержаниями металлов в рудах. Выделяют ванадиевые (V>Ni) и никелевые $(\mathrm{Ni}>\mathrm{V})$ типы нефтей. Как было показано, уже на ранних стадиях образования абиогенной нефти пары $N-N i$ и $S-V$ выполняют системообразующую функцию [310,311]. Ванадиевые нефти являются тяжелыми, высокосмолистыми, сернистыми и низкоазотистыми, а никелевые - легкие, с низким содержанием серы, смол и асфальтенов и азотистыми [38,188]. Проявление подобных закономерностей на разных уровнях генезиса нефти свидетельствует о проявлении фрактальности, обусловленной системообразующей функцией пары $N-N i$ и $S-V[310,311]$.

Экспериментально изучив процессы разрушения горных пород методами деформаций - растяжение и сдвиг, показано, что конфигурации трещин в обоих случаях имели фрактальную структуру с одинаковой размерностью 1,62-1,64 [312]. Для трещиноватости карбонатного коллектора можно выделить шесть типов фрактальных-структурных уровней: ультра-, микро-, мезо-, макро-, мета- и мегатрещины. В работах [313-315] В.А. Шестовалов объясняет образование древовидной системы трещин при больших глубинах и фрактальный механизм газовыделения из угольного пласта на малых и больших глубинах. 
Для повышения нефтеотдачи в нефтеносный пласт закачивают воду под давлением. При вытеснении нефти водой из трещиновато-пористого пласта коллектора и из неоднородной среды, содержащей малопроницаемые включения, вода под действием гидродинамических сил стремится вытеснить нефть из хорошо проницаемых зон, она прорывается по высокопроницаемой среде или по трещинам, малопроницаемые блоки, насыщенные нефтью, оказываются окруженными со всех сторон водой. В результате значительная часть пласта не охвачивается заводнением, площадной коэффициент охвата низок. При вытеснении нефти водой значительная часть нефти остается в пласте неизвлеченной. Низкая нефтеотдача при заводнении, наряду с горно-геологическими условиями, связана с особенностями гидродинамики водонефтяной системы в пористой среде. Большая остаточная нефтенасыщенность служит причиной низкого коэффициента вытеснения. При увеличении обводненности дебит уменьшается, что обусловлено уменьшением относительной проницаемости коллектора [316]. Проницаемость, которая относится к числу наиболее важных параметров коллектора и тесно связана со структурой пустотного пространства. Следует отметить, что к проблеме нефтеотдачи и теоретического описания процесса обводнения и нефтеотдачи посвящены многочисленные работы [317-319] Так, в учебнике [317] изложена гидродинамическая теория одно- и многофазной фильтрации жидкостей и газов в однородных и неоднородных пористых и трещиноватых средах. Описаны гидродинамические методы повышения нефтегазоотдачи и неизотермическая фильтрация при тепловых методах воздействия на пласт и в естественных термобарических условиях. Авторы учебного пособия [319] рассматривают добычу углеводородов как стохастический процесс, обладающий фрактальными свойствами. Представлено строгое доказательство основных свойств функции Вейерштрасса-Мандельброта применительно к описанию процесса нефтедобычи. В работе [318] показано, что с 
ростом градиента давления воды изменяется фильтрационная способность коллектора. Это связано с изменением действующей толщины пласта, которая для каждого конкретного коллектора при различных градиентах давления различна. С ростом градиента давления до критического значения в процессе фильтрации вовлекаются все более мелкие поры коллектора. При этом одновременно увеличивается проницаемость трещин, пористых блоков и общая мощность трещиновато - пористого пласта. Рассмотрены также задачи, описывающие процесс диффузии в пористых средах, где сильно вязкая нефть вытесняется слабо вязкой водой. Следует отметить,что в работах [305,320] показано, что оптимальная депрессия на всех типах флюидонасыщенных коллекторов в процессе его освоения равна 5 МПа.

При закачке воды под давлением в нефтеносный пласт наблюдаются вязкие «пальцы», которые имеют фрактальную структуру. Проблема образования так называемых вязких пальцев в пористых средах имеет первостепенное значение для добычи нефти. Она представляет интерес и для гидродинамики, и для физики пористых сред. Вязкие пальцы в пористых средах имеют фрактальную природу. При вытеснении жидкости с большей вязкостью менее вязкой жидкостью, в начале процесса плоская поверхность фронта вытеснения переходит в поверхность, напоминающую пальцы перчатки. Последовательное дробление кончиков пальцев приводит к возникновению фрактальных кластеров. Как было отмечено, такие структуры получили название вязких пальцев. При превышении вязкости нефти по отношению к воде происходит деформация фронта вытеснения с образованием фрактальных структур [321]. В работе [322] установлены основные закономерности образования вязких пальцев при вытеснении жидкости с большей вязкостью менее вязкой жидкостью с большей температурой в зависимости от фильтрационных и термодинамических характеристик жидкостей и пористой среды. В частности, показано, что рост вязких пальцев ускоряется 
при увеличении числа Пекле Ре и отношения вязкости нефти к воде. Показано также, что уменьшение отношения приведенной теплоемкости вытесняющей жидкости к суммарной теплоемкости породы и вытесняемой жидкости приводит к образованию вязких пальцев с повышенной температурой за фронтом вытеснения; в неоднородной по проницаемости среде рост вязких пальцев происходит преимущественно в местах с наибольшей скоростью потока. При вытеснении высоковязкой жидкости с помощью жидкости менее вязкой возникает нестабильность, которая может быть описана законом Дарси при некоторых начальных изменениях. Вязкие пальцы наблюдаются также при вытеснении глицерина воздухом в двумерной модели пористой среды. На основании анализа зависимости предельных напряжений сдвига от толщины межфазных слоев желатина, образующихся на границах раздела жидких несмешивающихся фаз (водный раствор желатина / неполярная углеводородная фаза: бензол и четыреххлористый углерод), показано, что желатин образует фрактальную структуру. Величины фрактальной размерности на границы с бензолом и четыреххлористым углеродом составляют 1,75 и 1,36, соответственно [323].

Концепция фрактала проявляется не только в движении пластовых флюидов по однородному коллектору, но и на структурном уровне состава нефти.

Согласно современным коллоидным представлениям, нефтяные дисперсные системы представляют собой коллоидные системы, дисперсная фаза которых состоит из ассоциатов смолистоасфальтеновых компонентов, где ядром выступают асфальтены, а состав сольватной оболочки, в соответствии с полярностью, представлен различными фракциями смол [324]. Массовая доля асфальтенов в тяжелых нефтях достигает 0,2-0,25\%. Плотность твердых асфальтенов больше плотности самой нефти [325]. Таким образом, в нефтяных системах к агрегированию и образованию коллоидов склонны молекулы, входящие во фракцию 
асфальтенов. Асфальто-смолистая часть нефтей представляет собой вещество темного окраса, которое частично растворяется в бензине. Растворившаяся часть - асфальтены. Они обладают способностью набухать в растворителях, а затем переходить в раствор. Растворимость асфальтенов в смолисто-углеродных системах возрастает с уменьшением концентрации легких углеводородов и увеличением концентрации ароматических углеводородов. Смолы не растворяются в бензине и являются полярными веществами с относительной молекулярной массой 500-1200. В них содержится основное количество кислородных, сернистых и азотистых соединений нефти. Таким образом, асфальтены являются полимером, состоющим из мономерных звеньев (рис. 5.2) [326].

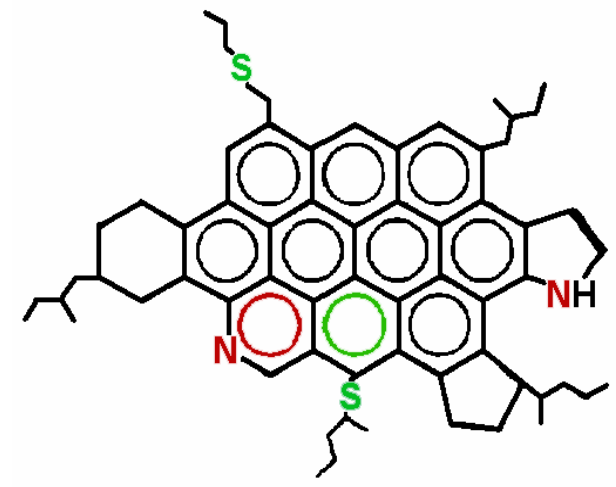

Рис.5.2. Типичное строение мономера асфальтенов.

Авторы работ [327-329] для объяснения аномально высоких значений плотности и вязкости некоторых природных нефтей принимают возможность самоассоциации взвешенных коллоидных асфальтенов в большое число четко различающихся коллоидных структур, характеризуемых единой фазовой диаграммой. Самоассоциация дисперсной фазы зависит от концентрации [327,328] и температуры [329]. Каждая концентрационная фаза это граница, за которой система переходит в новое качественное 
состояние. В работах [327,328] определены шесть концентрационных фаз асфальтенов. Так, при концентрации асфальтенов от 0.1 г/л до 0.15 г/л из мономеров асфальтенов образуются олигомеры. При концентрации 1-3 г/л из олигомеров получаются стэкинг-структурные наноколлоиды с размером 2-10 нм, которые состоят из 4-6 мономеров. Наноколлоиды в концентрационном интервале 7-10 г/л переходят в частицы с размером больше 10 нм. Наконец, при концентрации 25-30 г/л образуются рыхлые фрактальные структуры (рис. 5.3).

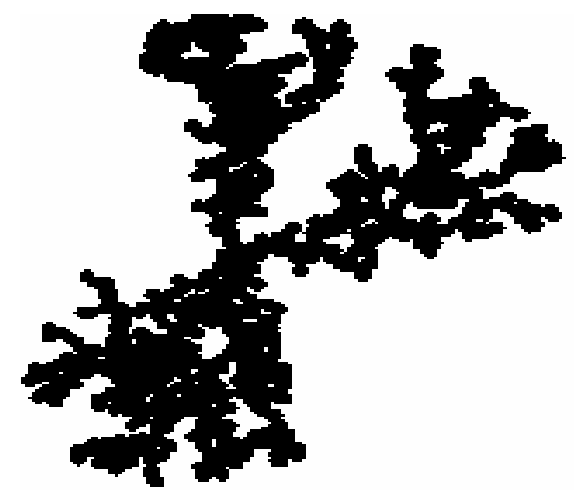

Рис. 5.3. Фрактальные структуры асфальтенов.

Следует отметить, что при концентрации 70-90 г/л образуются гелеобразные ассоциаты с размером 0.1 мкм. До концентрации $140 \div 160$ г/л система теряет седиментационную устойчивость, и взвешенные коллоиды асфальтенов выпадают в осадок. Таким образом, выпадение осадков асфальтенов приводит к образованию в коллекторе на границе вода-нефть твердой «корки» или целиков разных размеров, которые препятствуют миграции и без того вязкой тяжелой нефти [330]. Для моделирования образования целиков использованы стеклянные пластины размером 40x20 см, щелевое пространство между которыми размером 1,7 мм было заполнено стеклянной крошкой с пористостью 0,47 и 
коэффициентом фильтрации по воде 127 м/сут. В эксперименте вязкость вытесняемой нефти в 15 раз превосходила вязкость вытесняющей воды. Объемы воды, при заданном давлении поступавшие в модель, были от 1 мл до 15 мл. Показано, что имеет место неустойчивое вытеснение, создающее эффекты языкообразования-фрактальных структур. Обтекаемые разрастающимися языками воды нефтенасыщенные участки в виде целиков разных размеров,содержащих большие объемы остаточной пластовой нефти, могут долго оставаться в неподвижном капиллярнозапертом состоянии [330].

Надо отметить, что в коллекторе на границе вода-нефть твердая «корка» может образоваться также при длительном контакте воды с нефтью. Растворимость асфальтенов в нефти возрастает с увеличением концентрации ароматических углеводородов и уменьшением концентрации легких углеводородов. Известно, что растворимость ароматических углеводородов в воде больше, чем растворимость алканов. При длительном контакте воды с нефтью постепенно уменьшаются концентрации ароматических углеводов и возрастают относительные концентрации алканов в нефти, что приводит к потере седиментационной устойчивости взвешенных коллоидов асфальтенов, в результате чего асфальтены выпадают в осадок, тем самым в коллекторе на границе раздела фаз образуется твердая корка [280]. Этот вывод согласуется с эффектом «плохого растворителя нефти». В работе [331] исследованы изменения размеров и формы коллоидных частиц и кластеров в смеси н-гептана с тяжелой нефтью Венесуэлы сорта Boscan (относит. плотность 0.993; 17 масс. \% асфальтенов). Показано, что в смеси $66 \%$ н-гептан - нефть через 2 часа исходные квазисферические частицы коллоидов асфальтенов агрегируют в крупные кластеры с ярко выраженной фрактальной структурой.

В нефти высокомолекулярные парафины находятся в растворённом и взвешенном состоянии. На холоде растворимость их в нефти и нефтяных фракциях невелика, но при нагревании около 
$40{ }^{0} \mathrm{C}$ парафины неограниченно растворяются в них. Так как в недрах Земли высокая температура, то в нефтях парафины находятся в растворённом состоянии, выделяясь из них через фракталообразные структуры в виде твёрдой фазы при подъёме нефти на поверхность или при заводнении холодной водой.

\section{2. Залежи нефти и газа как хородинамическая система}

Система - это часть Вселенной, которую мы выделяем для исследования. Система - совокупность элементов со связями между ними, подчиняющимся соответствующим законам композиции. Система взаимодействует с внешним миром как единое целое. Каждый элемент системы внутри себя считается неделимым. Элементный состав может содержать однотипные (гомогенные системы) и разнотипные (гетерогенные системы) элементы. Элементы могут быть вещественные, энергетические и информационные. Система может быть изолирована от внешнего мира или взаимодействовать с ней [332,333].

Термодинамическая система - выделяемая (реально или мысленно) для изучения- макроскопическая физическая система, состоящая из большого числа частиц и не требующая для своего описания привлечения микроскопических характеристик отдельных частиц. По характеру взаимодействия с окружающей средой различают системы:

1) открытые;

2) закрытые;

3) изолированные;

4) адиабатически изолированные.

Открытые системы могут обмениваться с окружающей средой энергией, веществом и, что не менее важно, информацией. 
Закрытая система - термодинамическая система, которая может обмениваться с окружающей средой теплом и энергией, но не веществом.

Изолированная система (замкнутая система) - термодинамическая система, которая не обменивается с окружающей средой ни веществом, ни энергией. В термодинамике постулируется, что изолированная система постепенно приходит в состояние термодинамического равновесия, из которого самопроизвольно выйти не может.

Адиабатически изолированная система - термодинамическая система, которая не обменивается с окружающей средой энергией в форме теплоты.

Для описания термодинамической системы используются макроскопические параметры, характеризующие свойства самой системы: температуру, давление, объема, массу и химический состав компонентов, магнитную индукцию, электрическую поляризацию и др.

Если параметр имеет одно и то же значение, не зависящее от размера любой выделенной части равновесной системы, то он называется неаддитивным или интенсивным, если же значение параметра пропорционально размеру части системы, то он называется аддитивным, или экстенсивным. Давление и температура - неаддитивные параметры, а объем и масса - аддитивные параметры.

Состояние термодинамической системы, когда все ее параметры при неизменных внешних условиях не изменяются со временем, называют равновесным.

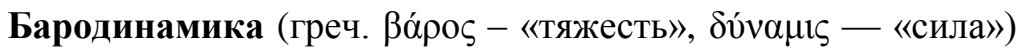
- это изобретение А.В. Шестопалова [334]. Если в термодинамике все происходит под действием температуры, то в бародинамике Шестопалова все процессы протекают под действием давления, отсюда у него свои собственные псевдоагрегатные состояния 
вещества и фазовые переходы типа плавления, кипения, сублимации и конденсации.

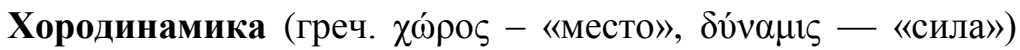
это изобретение Г.С. Симоняна [335-337]. Это процессы, которые протекают в подземных системах при изохорных условиях $(\mathrm{V}=$ const, $\mathrm{P} / \mathrm{T}=\mathrm{const})$. Термин хор на армянском языке означает: глубина и замкнутое пространство в глубине - яма. В изохорных условиях находятся, например, коллекторы углеводородов и ловушки нефти и газа [305-307]. Коллектор -это хородинамическая система, где накоплены и длительно сохранены нефть и газ, который сверху и снизу изолирован непроницаемыми породами. Хородинамическая система обладает фрактальностью [310,311] и синергичностью [338]. Хородинамическая система также может быть открытой, замкнутой и изолированной.

Эндогенные летучие флюиды, в том числе и УВ, в ходе дегазационных процессов перемещаются к поверхности Земли, по линии геотермического градиента (нарастание температуры в градусах Цельсия на единицу глубины). Следует отметить, что геотермический градиент изменяется от места к месту в зависимости от геологических условий, эндогенной активности в различных районах, а также неоднородной теплопроводности горных пород. Примером тому являются два резко различных градиента:

1) $150^{\circ} \mathrm{C}$ на 1 км в штате Орегон (США),

2) $6^{\circ} \mathrm{C}$ на 1 км зарегистрирован в Южной Африке.

Средний геотермический градиент принимается в $30{ }^{\circ} \mathrm{C}$ на 1 км [339].

Известно, что эндогенные мантийные флюиды являются многокомпонентной смесью химических веществ, которые имеют различные критические параметры - температуру и давление. Флюиды в глубинных условиях рассматриваются как нечто неопределенное, не газ и не жидкость. Так, при температурах, превышающих критическую для данного вещества, его конденсация 
невозможна, а при более низких температурах конденсируется и сбрасывается все избыточное количество вещества в конденсат по отношению к предельно допустимому парциальному давлению. Давления конденсированной и газовой фаз вещества, охладившегося до свойственной ему критической температуры в составе многокомпонентной газовой смеси, всегда будут отличаться друг от друга

Таким образом, возможность образования конденсатов определяется критическими температурами веществ, входящих в состав газовой смеси. Однако процесс образования конденсатов в эндогенных условиях контролируется, прежде всего, температурным профилем вмещающих пород на пути движения газовой смеси и количеством солей в смеси.

При критической температуре воды $\left(374{ }^{\circ} \mathrm{C}\right)$ гидротермальный процесс в условиях относительно невысоких давлений начинается при температуре около $400{ }^{\circ} \mathrm{C}$. Однако в связи с тем, что гидротермальные растворы содержат много растворенных веществ, в частности $\mathrm{NaCl}, \mathrm{NaOH}$ и другие, их критическая температура оказывается более высокой. Так при содержании $10 \%$ $\mathrm{NaCl}$ она составляет уже $437^{\circ} \mathrm{C}$, а при концентрации $\mathrm{NaOH}$ в 0.22 моль/л - уже $442.3{ }^{\circ} \mathrm{C}$. В таблицах 6.1-6.3 приведены критические температуры и критические давления алканов, алкенов, аренов, алкилсульфидов и азотистых соединений. Получается хорошая обратная корреляция между Ткр и Ркр.

Таблийа 5.1.

Критические термобары алканов, алкенов и аренов.

\begin{tabular}{|l|c|c|}
\hline \multicolumn{1}{|c|}{ Вещество } & Ткр, ${ }^{\circ} \mathbf{C}$ & Ркр, МПа \\
\hline Метан, $\mathrm{CH}_{4}$ & -82.55 & 4.63 \\
\hline Этилен, $\mathrm{C}_{2} \mathrm{H}_{4}$ & 9.20 & 5.04 \\
\hline Этан, $\mathrm{C}_{2} \mathrm{H}_{6}$ & 32.30 & 4.87 \\
\hline Ацетилен, $\mathrm{C}_{2} \mathrm{H}_{2}$ & 35.10 & 6.14 \\
\hline Пропен, $\mathrm{C}_{3} \mathrm{H}_{6}$ & 91.80 & 4.62 \\
\hline Пропан, $\mathrm{C}_{3} \mathrm{H}_{8}$ & 96.67 & 4.26 \\
\hline
\end{tabular}




\begin{tabular}{|l|l|l|}
\hline 2-метилпропан, $\mathrm{C}_{4} \mathrm{H}_{10}$ & 134.90 & 3.65 \\
\hline 2-метилпропен, $\mathrm{C}_{4} \mathrm{H}_{8}$ & 144.70 & 4.00 \\
\hline Бутен-1, $\mathrm{C}_{4} \mathrm{H}_{8}$ & 146.40 & 4.02 \\
\hline Бутан, $\mathrm{C}_{4} \mathrm{H}_{10}$ & 152.01 & 3.80 \\
\hline 2.2-диметилпропан, $\mathrm{C}_{5} \mathrm{H}_{12}$ & 160.60 & 3.20 \\
\hline 2-метилбутан, $\mathrm{C}_{5} \mathrm{H}_{12}$ & 187.20 & 3.12 \\
\hline Пентан, $\mathrm{C}_{5} \mathrm{H}_{12}$ & 196.75 & 3.37 \\
\hline Гексан, $\mathrm{C}_{6} \mathrm{H}_{14}$ & 234.25 & 2.97 \\
\hline Гептан, $\mathrm{C}_{7} \mathrm{H}_{16}$ & 267.05 & 2.74 \\
\hline Октан, $\mathrm{C}_{8} \mathrm{H}_{18}$ & 295.61 & 2.49 \\
\hline Нонан, $\mathrm{C}_{9} \mathrm{H}_{20}$ & 322.25 & 2.32 \\
\hline Декан, $\mathrm{C}_{10} \mathrm{H}_{22}$ & 346.35 & 2.11 \\
\hline Ундекан, $\mathrm{C}_{11} \mathrm{H}_{24}$ & 369.45 & 1.96 \\
\hline Додекан, $\mathrm{C}_{12} \mathrm{H}_{26}$ & 386.00 & 1.81 \\
\hline Тридекан, $\mathrm{C}_{13} \mathrm{H}_{28}$ & 404.05 & 1.78 \\
\hline Тетрадекан, $\mathrm{C}_{14} \mathrm{H}_{30}$ & 421.85 & 1.68 \\
\hline Пентадекан, $\mathrm{C}_{15} \mathrm{H}_{32}$ & 437.45 & 1.60 \\
\hline Гексадекан, $\mathrm{C}_{16} \mathrm{H}_{34}$ & 452.00 & 1.42 \\
\hline Гептадекан, $\mathrm{C}_{17} \mathrm{H}_{36}$ & 462.00 & 1.32 \\
\hline Октадекан, $\mathrm{C}_{18} \mathrm{H}_{38}$ & 480.05 & 1.30 \\
\hline Нонадекан, $\mathrm{C}_{19} \mathrm{H}_{40}$ & 486.85 & 1.20 \\
\hline Бензол, $\mathrm{C}_{6} \mathrm{H}_{6}$ & 289.50 & 4.92 \\
\hline Толуол, $\mathrm{C}_{7} \mathrm{H}_{8}$ & 320.80 & 4.22 \\
\hline n-ксилол, $\mathrm{C}_{8} \mathrm{H}_{10}$ & 345.00 & 3.44 \\
\hline m-ксилол, $\mathrm{C}_{8} \mathrm{H}_{10}$ & 346.00 & 3.65 \\
\hline о-ксилол, $\mathrm{C}_{8} \mathrm{H}_{10}$ & 359.00 & \\
\hline
\end{tabular}

$$
\begin{aligned}
& T_{\text {кр }}=(595.42 \pm 22.66)-(115.52 \pm 6.87) \cdot P_{\text {кр }}, R^{2}=0.95855, N=27 \\
& T_{\text {кр }}=(646.75 \pm 16.34)-(138.64 \pm 5.75) \cdot P_{\text {кр }}, R^{2}=0.98319, N=22
\end{aligned}
$$

Алканы

$$
T_{\text {кр }}=(362.45 \pm 111.93)-(58.15 \pm 23.18) \cdot P_{к р}, R^{2}=0.82829, N=5 \text {. }
$$

Алкены

$$
T_{\text {кр }}=(499.73 \pm 31.73)-(42.38 \pm 7.94) \cdot P_{\text {кр }}, R^{2}=0.95113, N=5 \text {. }
$$

Арены 
Таблий 5.2.

Критические термобары сулфидов (меркаптанов).

\begin{tabular}{|l|c|c|}
\hline \multicolumn{1}{|c|}{ Вещество } & Ткр, ${ }^{\circ} \mathbf{C}$ & Ркр, МПа \\
\hline Сероводород, $\mathrm{H}_{2} \mathrm{~S}$ & 100.40 & 9.01 \\
\hline Метантиол, $\mathrm{CH}_{4} \mathrm{~S}$ & 196.80 & 7.23 \\
\hline Этантиол, $\mathrm{C}_{2} \mathrm{H}_{6} \mathrm{~S}$ & 225.50 & 5.49 \\
\hline Диметилсулфид, $\mathrm{C}_{2} \mathrm{H}_{6} \mathrm{~S}$ & 229.90 & 5.53 \\
\hline Диэтилсулфид, $\mathrm{C}_{4} \mathrm{H}_{10} \mathrm{~S}$ & 238.80 & 3.96 \\
\hline
\end{tabular}

$$
\begin{aligned}
& T_{\text {кр }}=(368.98 \pm 41.26)-(27.34 \pm 6.37) \cdot P_{к р}, R^{2}=0.92736, N=5 . \\
& \text { Сулфиды }
\end{aligned}
$$

Таблица 5.3.

Критические термобары азотистых соединений (аминов).

\begin{tabular}{|l|c|c|}
\hline Дициан, $\mathrm{C}_{2} \mathrm{~N}_{2}$ & 126.60 & 5.82 \\
\hline Аммиак, $\mathrm{NH}_{3}$ & 132.30 & 11.28 \\
\hline Метиламин, $\mathrm{CH}_{5} \mathrm{~N}$ & 156.90 & 7.46 \\
\hline Триметиламин, $\mathrm{C}_{3} \mathrm{H}_{9} \mathrm{~N}$ & 160.10 & 4.07 \\
\hline Диметиламин, $\mathrm{C}_{2} \mathrm{H}_{7} \mathrm{~N}$ & 164.50 & 5.31 \\
\hline Этиламин, $\mathrm{C}_{2} \mathrm{H}_{7} \mathrm{~N}$ & 177.00 & 6.60 \\
\hline Синильная кислота, $\mathrm{HCN}$ & 183.50 & 5.39 \\
\hline Диэтиламин, $\mathrm{C}_{4} \mathrm{H}_{11} \mathrm{~N}$ & 223.30 & 3.71 \\
\hline Триэтиламин, $\mathrm{C}_{6} \mathrm{H}_{15} \mathrm{~N}$ & 260.10 & 3.00 \\
\hline Пиридин, $\mathrm{C}_{5} \mathrm{H}_{5} \mathrm{~N}$ & 344.20 & 6.08 \\
\hline Гидразин, $\mathrm{N}_{2} \mathrm{H}_{4}$ & 380.00 & 14.50 \\
\hline Анилин, $\mathrm{C}_{6} \mathrm{H}_{7} \mathrm{~N}$ & 426.00 & 5.31 \\
\hline
\end{tabular}

$$
T_{\text {кр }}=(244.73 \pm 29.85)-(11.74 \pm 7.74) \cdot P_{\text {кр }}, R^{2}=0.68361, N=9
$$

Амины.

Флюидный поток достигает критической температуры воды $\left(374{ }^{\circ} \mathrm{C}\right)$ на глубине $\sim 12,3$ км. В момент охлаждения до этой температуры происходит массовый сброс в конденсат всех избыточных паров воды, формирование теплопроводного охлаждающего горизонта и конденсация. Начиная с глубины 16,2 км. до 
глубины критической температуры воды конденсируются алкены от нонадекана до додекана, а также анилин и гидразин.

Эндогенные мантийные летучие флюиды, по мере перемещения к поверхности Земли, транспортируют с более глубоких горизонтов их повышенные давление и температуру.

Более легкие углеводороды, такие, как метан, этан, этилен, пропан и пропилен, имея более низкие критические температуры, полностью остаются в газообразном состоянии. Фильтруясь через конденсат более тяжелых углеводородов, они частично поглощаются в ходе реакций полимеризации.

В вышеописанных зонах образования углеводородов конденсируется и поглощается значительная часть остаточных газов эндогенного флюида. В результате динамическая активность флюидной системы резко падает и появляется тенденция накопления углеводородного сырья в благоприятных геологических структурах - нефтяных ловушках [340-343].

В зонах конденсации возможно образование УВ соединений за счёт взаимодействия $\mathrm{H}_{2}, \mathrm{CO}, \mathrm{CO}_{2}, \mathrm{NH}_{3}, \mathrm{H}_{2} \mathrm{~S}$ и воды, а также при конденсации низкомолекулярных УВ с образованием более высокомолекулярных УВ.

\section{3. Оценка зрелости нефтяных залежей с помощью энтропийного индекса}

Концепция глубинного происхождения нефти и газа основана на представлениях о том, что образование углеводородов происходит в мантийных очагах вследствие неорганического синтеза [1]. Мантийные флюиды по глубинным разломам перемещаются и проникают в земную кору, где и образуют нафтидные системы. «Нафтиды»- углеводороды в газовом, жидком, полутвердом и твердом состояниях или в виде смеси этих фаз. Совокупность элементов со связями между ними, подчиняющиеся соответствующим законам композиции. Таким образом можно 
констатировать, что нафтиды представляют собой неустойчивые открытые флюидодинамические системы, которые под воздействием техногенных, глубинно-земных, поверхностных, космических процессов могут самоорганизоваться в сторону хаоса или порядка. Процесс самоорганизации-спонтанного увеличения порядка или организации в системе, состоящий из многих элементов, происходящий под действием внешней среды. Мерой хаоса является энтропия, а закон возрастания ее отражает возрастающую дезорганизацию системы. В открытых хородинамических системах, к которым относятся и нафтидные, могут идти процессы как с возрастанием, так и с уменьшением энтропии [337]. При этом в экосистеме вещество распределяется таким образом, что в одних местах энтропия возрастает, а в других резко снижается. В целом же, система не теряет своей организованности или высокой упорядоченности. Энтропия каждого макроскопического состояния связана с вероятностью реализации этого состояния. Способность системы снижать неупорядоченность внутри себя иногда интерпретируют как способность накапливать синтропию.

Система взаимодействует с внешним миром как единое целое. В целом же, система не теряет своей организованности или высокой упорядоченности. Чтобы система действовала и взаимодействовала со средой, она должна потреблять информацию из среды и сообщать информацию среде. Впервые понятия энтропия и информация связал Шеннон [344]. С его подачи энтропия - это количество информации, приходящейся на одно элементарное сообщение источника, вырабатывающего статистически независимые сообщения. Получение какого-либо количества информации равно потерянной энтропии. Информационная энтропия или индекс Шенона для независимых случайных событий х с N возможными состояниями рассчитывается по формуле 


$$
H=-\sum_{i=1}^{N} p_{i} \log _{2} p_{i}
$$

где: $\mathrm{P}_{\mathrm{i}}$ - вероятность частоты встречаемости некоторого события. $\mathrm{P}_{\mathrm{i}}=n / N$.

С использованием индекса Шеннона в работе [345]. получен геоэкологический эволюционный организованный индекс (ГЕВОРГ).

С использованием индекса ГЕВОРГ была проведена комплексная оценка качества поверхностных вод [346-350] и сделан структурный анализ состояния биологических систем на уровне белков, рибонуклеиновой кислоты, клетки [351-353] и структурный анализ состояния деревьев [354]. G - функция, которая характеризует геоэкологические эволюцирующие системы со стороны соотношения порядка и хаоса, мерами которых являются геоэкологическая синтропия - I и энтропия Шенона $\mathrm{H}$, соответственно $\mathrm{G}=\boldsymbol{H} / \boldsymbol{I}$. Значения $\mathrm{G}$-функции говорят о том, что и в какой мере преобладает в структуре системы: хаос или порядок. Так, если $\mathrm{G}<1$, то в структуре системы преобладает порядок, в противном случае, когда $\mathrm{G}>1$ - организация системы является равновесной.

Для расчета значений $\mathrm{I}, \mathrm{H}$ и $G$ пользуемся следующим вычислительным алгоритмом:

1. определяется число элементов в системе- $n$.

2. далее оценивается общая сумма элементов: $N=\Sigma n$,

3. потом вычисляются: $\log _{2} N, n \log _{2} n u \sum n \log _{2} n$,

4. рассчитывается геоэкологическая синтропия (I) и энтропия $(\mathrm{H})$ :

$$
I=\sum n \log _{2} n / \mathrm{N} \text { и } H=\log _{2} N-I
$$

5. после чего определяется энтропийный индекс : $G=H / I$. 
В соответствии с постановкой задачи произведены расчеты энтропийного индекса природного газа, попутных газов нефтяных месторождений и нефтяных фракций[47,338,355-359]. В таблицах 5.4 - 5.9 приведены соответствующие расчеты энтропийного индекса.

1) Природный газ

Он представляет собой смесь углеводородных газов, состоящих в основном из метана, но обычно включающую различные количества других высших алканов, а иногда и небольшой процент диоксида углерода, азота, сероводорода или гелия.

Таблица 5.4.

Химический состав (об. \%) и значения I, $H, G$ природного газа.

\begin{tabular}{|c|c|c|c|c|c|c|c|}
\hline $\mathbf{C H}_{\mathbf{4}}$ & $\mathbf{C}_{\mathbf{2}} \mathbf{H}_{\mathbf{6}}$ & $\mathbf{C}_{\mathbf{3}} \mathbf{H}_{\mathbf{8}}$ & $\mathbf{N}_{\mathbf{2}}$ & $\mathbf{C O}_{\mathbf{2}}$ & $\mathbf{I}$ & $\mathbf{H}$ & $\mathbf{G}$ \\
\hline 94.0 & 3.0 & 0.4 & 2 & 0.6 & 6.25 & 0.38 & 0.06 \\
\hline
\end{tabular}

Любопытно, что для природного газа $\mathrm{G}=0,066$, что свидетельствует о высокой степени свободы газовой фазы.

2) Попутный нефтяной газ

Это природный углеводородный газ, растворенный в нефти или расположенный в «шапках» нефтяных и газоконденсатных месторождений. Количество попутного нефтяного газа ПНГ в одной тонне нефти может варьироваться от одной или двух до нескольких тысяч кубометров. В отличие от природного газа, попутный нефтяной газ содержит помимо метана и этана большую долю пропана, бутана и паров более тяжелых углеводородов. Многие попутные газы, в зависимости от месторождения, также содержат неуглеводородные компоненты: сероводород и меркаптаны, диоксид углерода, азот, гелий и аргон. 
Таблица 5.5.

Химический состав (об. \%) и значения I, $H$, G нефтяных месторождений (попутного газа).

\begin{tabular}{|c|c|c|c|c|c|c|}
\hline Месторождение & \multicolumn{2}{|c|}{ Бавлинское } & \multicolumn{2}{|c|}{ Ромашкинское } & \multicolumn{2}{|c|}{ Узеньское } \\
\hline Состав & $\mathbf{n}$ & $n \log _{2} n$ & $\mathbf{n}$ & $n \log _{2} n$ & $\mathbf{n}$ & $n \log _{2} n$ \\
\hline $\mathrm{CH}_{4}$ & 35.0 & 182.1 & 38.8 & 204.66 & 50.2 & 283.45 \\
\hline $\mathrm{C}_{2} \mathrm{H}_{6}$ & 20.7 & 90.44 & 19.1 & 81.23 & 20.2 & 87.54 \\
\hline $\mathrm{C}_{3} \mathrm{H}_{8}$ & 19.9 & 85.81 & 17.8 & 73.89 & 16.8 & 68.34 \\
\hline $\mathrm{C}_{4} \mathrm{H}_{10}$ & 9.5 & 30.84 & 8.0 & 24 & 7.7 & 22.66 \\
\hline $\mathrm{C}_{5} \mathrm{H}_{12}$ & 5.8 & 14.70 & 6.8 & 18.79 & 3.0 & 4.75 \\
\hline $\mathbf{N}_{2}$ & 8.4 & 25.77 & 8.0 & 24 & 2.3 & 2.76 \\
\hline $\mathrm{CO}_{2}$ & 0.4 & 0 & 1.5 & 0.88 & 0 & 0 \\
\hline $\mathrm{N}$ & \multicolumn{2}{|c|}{100} & \multicolumn{2}{|c|}{100} & \multicolumn{2}{|r|}{100} \\
\hline$\sum n \log _{2} \mathrm{n}$ & \multicolumn{2}{|c|}{428} & \multicolumn{2}{|c|}{428} & \multicolumn{2}{|c|}{469} \\
\hline $\mathrm{I}$ & \multicolumn{2}{|c|}{4.28} & \multicolumn{2}{|c|}{4.28} & \multicolumn{2}{|c|}{4.69} \\
\hline $\mathrm{H}$ & \multicolumn{2}{|c|}{2.36} & \multirow{2}{*}{\multicolumn{2}{|c|}{$\begin{array}{l}2.36 \\
0.55\end{array}$}} & \multicolumn{2}{|c|}{1.95} \\
\hline G & \multicolumn{2}{|c|}{0.55} & & & \multicolumn{2}{|c|}{0.42} \\
\hline
\end{tabular}

3) Газ газоконденсатных месторождений.

Таблица 5.6.

Химический состав (об.\%) И значения I, H, G газоконденсатных месторождений.

\begin{tabular}{|l|c|c|c|c|c|c|c|c|c|c|}
\hline \multicolumn{1}{|c|}{ Состав } & $\mathbf{C H}_{\mathbf{4}}$ & $\mathbf{C}_{\mathbf{2}} \mathbf{H}_{\mathbf{6}}$ & $\mathbf{C}_{\mathbf{3}} \mathbf{H}_{\mathbf{8}}$ & $\mathbf{C}_{\mathbf{4}} \mathbf{H}_{\mathbf{1 0}}$ & $\mathbf{C}_{\mathbf{5}} \mathbf{H}_{\mathbf{1 2}}$ & $\mathbf{N}_{\mathbf{2}}$ & $\mathbf{C O}_{\mathbf{2}}$ & $\mathbf{I}$ & $\mathbf{H}$ & $\mathbf{G}$ \\
\hline Вуктыльское & 74,80 & 7,70 & 3,90 & 1,80 & 6,40 & 4,30 & 0,10 & 5.24 & 1.4 & 0.268 \\
\hline Оренбург & 84,00 & 5,00 & 1,60 & 0,70 & 1,80 & 3,5 & 0,5 & 5.76 & 0.84 & 0.146 \\
\hline Уренгой & 88,28 & 5,29 & 2,42 & 1,00 & 2,52 & 0,48 & 0,01 & 5.89 & 0.75 & 0.127 \\
\hline Ямбург & 89,67 & 4,39 & 1,64 & 0,74 & 2,36 & 0,26 & 0,94 & 5.95 & 0.69 & 0.116 \\
\hline
\end{tabular}

4) Синтез газ.

В работе [198] исследовано влияние разбавления синтез-газа азотом на процесс синтеза углеводородов из $\mathrm{CO}$ и $\mathrm{H}_{2}$ в присутствии $\mathrm{Co}-\mathrm{Al}_{2} \mathrm{O}_{3}$ катализаторов. Показано, что в результате разбавления сырья (31\% CO и 64\% $\left.\mathrm{H}_{2}\right)$ азотом $\left(57 \% \mathrm{~N}_{2}, 13,5 \% \mathrm{CO}\right.$ и $27 \% \mathrm{H}_{2}$ ) возрастает конверсия СО (с 16 до $53 \%$ ), селективность по метану возросла (с 3 до 8 \%), а селективность по высшим углеводородам несколько снизилась (с 95 до 90\%). 
Таблица 5.7.

Химический состав синтез- газа.

\begin{tabular}{|c|c|c|c|c|c|c|c|c|}
\hline Номер эксперимента & $\mathbf{C O}$ & $\mathbf{H}_{\mathbf{2}}$ & $\mathbf{N}_{\mathbf{2}}$ & $\mathbf{C O}_{2}$ & $\mathbf{A r}$ & $\mathbf{I}$ & $\mathbf{H}$ & $\mathbf{G}$ \\
\hline 1 & 31 & 64 & - & - & 5 & 5.46 & 1.18 & 0.216 \\
\hline 2 & 13 & 27 & 56 & - & 4 & 5.1 & 1.54 & 0.302 \\
\hline 3 & 12 & 24 & 57 & 7 & - & 4.93 & 1.71 & 0.347 \\
\hline
\end{tabular}

Следует отметить, что азот приводит к увеличению $\mathrm{G}$ функции.

5) Фракции нефти.

Таблица 5.8.

Значения I, H, G для фракций ряда нефтей.

\begin{tabular}{|l|c|c|c|}
\hline \multicolumn{1}{|c|}{ Фракция нефти } & I & H & G \\
\hline Первая фракция нефти Кумколь & 3.85 & 2.79 & 0.72 \\
\hline Вторая фракция нефти Кумколь & 3.45 & 3.19 & 0.91 \\
\hline Бензиновая фракция нефти Каражанбас & 3.18 & 3.46 & 1.09 \\
\hline Керосиновая фракция нефти Каражанбас & 3.28 & 3.36 & 1.02 \\
\hline
\end{tabular}

Из изложенного можно заключить:

1) В ряду природный газ $\rightarrow$ газ газоконденсатных месторождений $\rightarrow$ синтез-газ $\rightarrow$ попутный газ $\rightarrow$ нефть геоэкологический эволюционный организованный индекс $\mathbf{G}$ увеличивается. Любопытно, что для природного газа $\mathrm{G}=0.06$, что свидетельствует о высокой степени свободы газовой фазы.

2) Для нефти энтропийный индекс стремится к единице, что свидетельствует о том, что при образовании в ловушке нефти в основном из мантийного высокоэнергетического флюида структурная организация нефтяной залежи является равновесной.

3) Показано, что присутствие азота в природном газоконденсате, в попутных газах нефти и в синтез-газе приводит к стабилизации системы в направлении порядка.

4) Наряду с другими геоинформационными методами и технологиями можно рекомендовать использовать энтропийный индекс для оценки зрелости нефтяных залежей. 


\section{ГЛАВА 6 \\ ЗАГРЯЗНЕНИЕ И ДЕГРАДАЦИЯ НЕФТИ В \\ ГИДРОСФЕРЕ}

\section{1. Загрязнение гидросферы нефтью \\ и нефтепродуктами}

Нефтепродукты относятся к числу наиболее распространенных и опасных веществ, загрязняющих поверхностные воды. В составе нефти обнаружено свыше 1000 индивидуальных органических веществ, содержащих: углерод, водород, кислород, серу и азот. Нефть и продукты ее переработки представляют собой чрезвычайно сложную, непостоянную и разнообразную смесь низко и высокомолекулярных соединений, относящихся к различным гомологическим рядам $[2,4,10]$. Низкомолекулярные соединения представляют собой, в основном, парафиновые, нафтено-парафиновые и ароматические углеводороды. Высокомолекулярная часть нефти состоит из высокомолекулярных парафиновых углеводородов, моно- и конденсированных нафтено-парафиновых, моно- и бициклических ароматических углеводородов ряда бензола и нафталина, смол и асфальтенов. Таким образом, нефть это сложная многокомпонентная смесь, которая в зависимости от внешних условий проявляет свойства молекулярного раствора или дисперсной системы.

Сегодня нефть распространяется далеко за пределы промысла, путем перевозки в цистернах и танкерах и перекачкой по трубопроводам.

Различают несколько групп источников загрязнения Мирового океана. Это естественные и антропогенные источники. 
Основными природными источниками нефтяного загрязнения морской среды являются выходы нефти на дне моря и менее значительными источниками - эрозионные процессы.

Важнейшие антропогенные источники нефтяного загрязнения:

1) морские - морской транспорт, военные корабли, суда различного назначения, трубопроводы, установки и устройства, используемые при разработке ресурсов морского дна и его недр,

2) наземные - реки, озера и другие водные системы, куда загрязняющие вещества попадают с грунтовыми водами, а также в результате сброса сточных вод с различных береговых объектов,

3) атмосферные - различные промышленные предприятия, транспортные средства и другие объекты, откуда могут происходить выбросы в атмосферу углеводородных соединений

Основная причина загрязнения морей и океанов нефтью - это транспортирование нефти, главным образом за счет слива за борт танкерами и судами нефтесодержащих (балластных и промывочных) вод. В настоящее время по морю ежегодно транспортируется более 1 млрд. тонн нефти. До 0,5 \% перевозимой танкерами нефти выбрасывается в результате практики сброса промывочных и балластных вод в открытое море. Так как объем перевозок танкерами ежегодно возрастает, также возрастает загрязнение при перевозках нефти в морях, океанах, составляя $40 \%$ всего сброса нефти [360-362].

Серьезное беспокойство вызывает загрязнение океанов нефтью в результате крушения танкеров и выбросов нефти на буровых скважинах, расположенных в открытом море. Однако загрязнения, вызванные ими, составляют лишь 5 \% от общего количества загрязнений нефтяными углеводородами акватории мирового океана.

Загрязнение океанов и морей нефтью вызваны также выносом реками- 31,1\%, попадание из атмосферы -9,8 \% природные 
источники- $10 \%$, промышленные отходы и городские отходы- по $5 \%$, отходы прибрежных нефтеочистительных заводов- $3 \%$ и добыча нефти в открытом море- $2 \%$. Поверхностные стоки с различных территорий, в первую очередь промышленных, автодорожных, портовых, содержат нефтепродукты, такие как бензин, керосин, топливные и смазочные масла, а также различные соединения: бензол, толуол, ксилолы, жирные кислоты, фенолы, глицериды, стероиды, пестициды и металлоорганические соединения. Перечисленные соединения составляют около $90 \%$ и выше от суммарного количества всех органических примесей [360]. Необходимо помнить, что помимо названных источников существует множество побочных. Так, самолеты во время перелетов могут выбрасывать нефтяные загрязнители, попадающие в океан. При работе двигателей судов вращающиеся лопасти простых судов способствуют лучшему перемешиванию, увеличивается проникновение вредных веществ и выброшенных газов в толще воды.

Примерные объемы ежегодного загрязнения мирового океана нефтью:

1) 0,1 млн.т.н. - незначительные утечки,

2) 2,0 млн. т. - с бытовыми и ливневыми стоками, попадающими в реки и далее в моря,

3) 0, 5 млн. т. - промышленные стоки.

\section{2. Деградация нефти в гидросфере}

При попадании нефти в воду сразу же образуется поверхностная пленка, которая подвергается множеству физических, химических, биохимических и механических процессов; это прежде всего испарение, эмульгирование, растворение, окисление, биодеградация и седиментация. С первых секунд контакта нефти и нефтепродуктов с водной средой начинают быстро развиваться сложные превращения, длительность и результаты которых 
зависят как от свойств и состава самой нефти, так и от конкретной ситуации. Морские течения и атмосферная циркуляция обуславливают перемешивание и перемещение нефтепродуктов по всей акватории моря, что также приводит к загрязнению его шельфа и берегов. Распространение разлитой на водной поверхности нефти происходит под действием сил тяжести и контролируется ее вязкостью и силами поверхностного натяжения. Уже через 10 мин. после разлива 1 т нефти она распространяется на акватории в радиусе 50 м и толщиной слоя 110 мм, с последующим образованием более тонкой пленки (менее 1 мм) и покры-

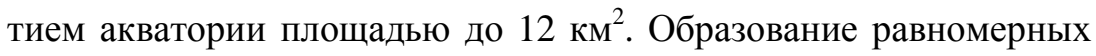
пленок определяется содержанием высокомолекулярных соединений (смол и асфальтенов), которые слабо трансформируются под воздействием внешних факторов [360]. При содержании асфальтенов и более $1 \%$, нефть плохо растекается по морской поверхности. На сегодняшний день площадь покрытия поверхности океана пленками нефтепродуктов меньше частоты их обнаружения и в среднем не превышает 1 \%. Нефть, как и поверхностная вода, движется со скоростью, составляющей несколько процентов от скорости ветра. По приблизительным оценкам, скорость перемещения нефтяных пленок составляет 60 \% от скорости течения и 2-4\% от скорости ветра.

\section{3. Физические процессы при трансформации нефти в гидросфере}

Таким образом, с первых секунд контакта нефти и нефтепродуктов с водной средой протекают сложные превращения, продолжительность которых зависит как от свойств и состава самой нефти, так и от конкретной ситуации [363].

При попадании нефти в воду одним из первых процессов самоочищения водоема является испарение, оно касается, в основном, летучих фракций нефти. Скорость испарения зависит 
от состава, площади испарения, типа «емкости», в которой они находятся, скорости движения воздуха, давления насыщенных паров нефти или нефтепродукта. Атмосфера способствует испарению летучих фракций нефти, последние подвергаются атмосферному окислению и переносу и могут вернуться на землю или в океан. Местом контакта атмосферы с морскими водами является поверхностный микрослой, в котором и происходит концентрирование углеводородов, что объясняется, прежде всего, несколько меньшей их плотностью по сравнению с плотностью воды и незначительной водорастворимостью. Многие источники такого поступления достаточно регулярны, но с поверхностного слоя путем испарения легких фракций и отлета с брызгами осуществляется и постоянный отток нефтяных углеводородов.

Наиболее интенсивно процесс испарения идет в первые часы, и уже через 0,5 часа после попадания нефти на водную поверхность летучих соединений остается гораздо меньше. К концу первых суток испаряется 50 \% соединений, содержащих углерода до $\mathrm{C}_{15}$ и полностью в течение 10 суток. Углеводороды $\mathrm{C}_{15}-\mathrm{C}_{25}$ удерживаются намного дольше, так к концу третьей недели улетучиваются с водной поверхности - 50 \% соединений $\mathrm{C}_{17}$, а тяжелые фракции более $\mathrm{C}_{25}$ практически не испаряются. При температуре $20-22{ }^{\circ} \mathrm{C}$ испаряется до $80 \%$ технического бензина, $22 \%$ керосина, $15 \%$ нефти и около 0,3 \% мазута. В целом потери при испарении составляют до 2/3 от всей массы разлитой по водной поверхности нефти. В целом только одно испарение может удалить до $50 \%$ углеводородов сырой нефти, до $10 \%$ тяжелой и до $75 \%$ легкой топливной нефти.

До $15 \%$ углеводородов нефти переходит в растворенное состояние, и этот переход в раствор растянут во времени и в большей степени зависит от гидродинамических и физико-химических условий в поверхностных водах. Максимально устойчивые в воде концентрации растворенных углеводородов составляют 0,3-

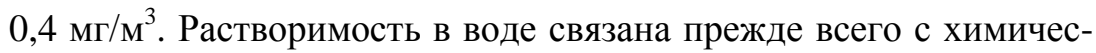


ким составом, она уменьшается со снижением содержания в нефтепродуктах ароматических углеводородов и с повышением концентраций парафиновых, то есть растворимость увеличивается в ряду: ароматические углеводороды > циклопарафины > парафины. Величины растворимости для нефти составляют 1050 , бензинов - до 5, керосинов - 2-5, дизельного топлива 8-22 мг/л. Наибольшей растворимостью отличаются такие соединения, как бензол (1800), толуол (600), ксилол (200) и этилбензол (150 $\mathrm{M \Gamma /л).}$

При растекании сырой нефти по воде она быстро теряет свои летучие компоненты, а оставшиеся более вязкие фракции начинают тормозить процесс растекания. Пленочная нефть в водной среде дрейфует преимущественно по направлению ветра со скоростью, часто превышающей скорость движения воды и составляющей 3-4 \% от скорости ветра.

По причине испарения нефтяных углеводородов и частично с растворением их в воде плотность и вязкость нефтяной пленки постепенно увеличиваются, поверхностное натяжение уменьшается - растекание прекращается. Волны и течения вызывают развитие турбулентных движений, и нефтяная пленка распадается на отдельные капли. Нефть быстро сорбирует воду (до $80 \%$ ее объема) и формирует эмульсию типа «вода в нефти», это зависит от физико-химических свойств нефтепродукта и ветра, волнения, вертикальной турбулентности, температуры воды, наличия взвесей и твердых частиц. Устойчивость водно-нефтяных эмульсий существенно зависит от поверхностно - активных веществ (ПАВ), которые концентрируются в межфазном слое эмульсии. В процесе формирования эмульсии принимают участие компоненты нефти с высокой поверхностной активностью, нафтеновые и жирные кислоты, смолы, вещества с низкими поверхностно-активными свойствами, асфальтенами [364]. Помимо эмульсии «вода в нефти» получается и эмульсия типа «нефть в воде», особенно при участии диспергирующих химических сое- 
динений. В этом случае происходит образование мельчайших капель нефти, что резко увеличивает поверхность раздела сред и способствует ускорению процессов разрушения нефтяных углеводородов. На образование этих агрегатов уходит 5-10 \% разлитой нефти. Размер агрегатов колеблется от 1 мм до 1 см, время существования таких нефтяных агрегатов составляет от 1 месяца до 1 года. Такие агрегаты под действием сил тяжести оседают на дно. В их состав входят в основном парафиновые и ароматические углеводороды, а эти очень стойкие образования существуют годами.

Присутствие в воде и на суше частиц различного состава приводит к тому, что часть нефти (10-30\%) сорбируется на них и постепенно уплотняется до весьма твердых комочков и шаров или осаждается на дно водоема; эти процессы наиболее активно происходят в прибрежной полосе и на мелководье из-за интенсивного перемешивания. Смоляные комки и агрегаты формируются также при перевозке нефти в танкерах и при балластировке и очистке танков они попадают в море.

Суммарный вес нефтяных агрегатов на всей акватории Мирового океана составляет не менее 0,5 млн т. Их содержание на морской поверхности в различных акваториях варьирует в широких пределах: от 0,001 до 2270 мг/м² [360].

Тяжелые фракции нефти могут сохраняться в толще грунта или в донных осадках в течение многих месяцев и даже лет.

\section{4. Влияние нефти на гидробионты и биохимические процессы при трансформации нефти в гидросфере}

Таким образом, нефть загрязняет не только поверхность воды, но и проникает на глубину. Вредному воздействию подвергаются организмы, живущие от поверхности до дна водного объекта. 
Даже при небольшой утечке нефти на поверхности воды образуется тонкая нефтяная пленка, которая препятствует проникновению солнечного света и воздуха в толщу воды, тем самым затрудняя поступление кислорода в воду, вызывая гибель планктона и других организмов. При этом в процессе дыхания в клетках накапливается $\mathrm{CO}_{2}$, что ведет к ацидозу, т. е. подкислению клеточной жидкости.

Для водных организмов нефть смертельно опасна даже в минимальных количествах. Нефть с высоким содержанием нафтеновых кислот, смол и серы более ядовита для гидробионтов. Растворимые в воде окисленные компоненты нефти могут обладать еще и прямым токсическим действием. Тяжелые фракции нефти, наподобие мазута и битума осевшие на дно, губят бентосные сообщества, а местами, например, в акваториях крупных портов, они образуют на дне сплошную корку, напоминающую асфальт. Жизнь в таких условиях невозможна. Донные беспозвоночные подвержены влиянию нефти и нефтепродуктов, которое выражается в изменении количественных и качественных характеристик донных сообществ, его структуре, причем это влияние зависит от качественного состава нефти или нефтепродуктов, их концентрации и периодичности загрязнения [365].

Накопление углеводородов мидиями зависит от нескольких факторов: степени их исходного загрязнения углеводородами нефти; физиологического состояния, связанного с отсутствием (недостатком) питательных веществ; химического спектра углеводородов в нефтях и нефтепродуктах. Моллюски и зоопланктон способствуют очищению воды от нефти. Однако, поскольку они не переваривают нефть, а лишь переносят её, то большого плюса это не приносит. Таким образом моллюски способны продолжительное время сохранять в своем теле нефть [366,367]. Моллюсками и зоопланктоном питаются другие животные. Они тоже отравляют свой организм. И таким образом нефть переходит по трофической цепочке к другим видам животных, даже если они 
находились не вблизи места разлива. Не исключена и гибель взрослых рыб в результате отравления растворенной нефтью, либо их вынужденной миграции из района катастрофы.

У морских птиц контакт с нефтью приводит к склеиванию оперения, птицы утрачивают способность держаться на воде и быстро гибнут от переохлаждения.

Биохимическое окисление нефти и нефтепродуктов осуществляется благодаря наличию в морской среде и в донных отложениях микроорганизмов, способных утилизировать органические соединения в качестве своего источника углерода и энергии.

Разлившись на земной поверхности и водах, нефть оказывается в качественно новых условиях: из анаэробной обстановки (с очень замедленными темпами химических процессов) она попадает в аэробную среду, в которой огромную роль играют биохимические факторы и прежде всего деятельность микроорганизмов. Будучи высокоорганизованной субстанцией, состоящей из множества соединений, нефть деградирует очень медленно. Процессы окисления одних структур ингибируются другими, трансформация отдельных соединений идет по пути образования форм, в дальнейшем плохо окисляемых. Разрушение самих товарных нефтепродуктов осуществляется путем и химического окисления, и биоразложения, а соотношение и скорость этих процессов зависят от условий среды. Ускоренное окисление нефтяных углеводородов будет происходить при хорошем насыщении воды кислородом (для полного окисления 1 л нефти требуется 3300 г $\mathrm{O}_{2}$ ), а наиболее благоприятные условия создаются на границе раздела море-воздух. На скорость биодеградации нефти влияют также значения $\mathrm{pH}$, температура и соленость водной среды. Оптимальные значения $\mathrm{pH}$ для благоприятного течения биоразложения составляют 6,0-7,5. Отрицательное влияние на скорость биодеградации нефтяных углеводородов оказывает рост солености водной среды. При сравнении значимости перечисленных факторов, для деструкции нефтяных углеводородов отмечают, 
что влияние температурного фактора намного выше, чем $\mathrm{pH}$ и солености.

Так, изменения периода полураспада нефтей от температуры в 25 раз больше, чем от изменения $\mathrm{pH}$, и в 8 раз больше, чем от изменения солености.

Активность микроорганизмов определяет окончательную судьбу нефти в море. При разрушении нефти в морской среде накапливаются продукты неполного окисления некоторых углеводородов, которые, в свою очередь, являются субстратом для дальнейшего воздействия микрофлоры; это гидроперекиси, спирты, фенолы, кетоны, альдегиды, органические кислоты, аминокислоты, пигменты, липиды, сахара, полисахариды. Понятно, что сложность состава нефтей и нефтепродуктов требует разнообразия микроорганизмов, способных атаковать как компоненты нефти, так и продукты их метаболизма. Поэтому сырые нефти и индивидуальные углеводороды более эффективно разрушаются смешанным бактериальным населением, чем отдельными штаммами. В загрязненных же акваториях распространены липолитические, протолитические, фенолокисляющие, денитрифицирующие и другие бактерии - чем больше число их видов, тем шире возможности катализа окисления различных органических веществ в составе нефти. В процессах, окисляющих углеводороды, участвует 70 родов микроорганизмов и 30 видов грибов. При недостатке связанного азот содержания кислорода менее 5 мг/л и $\mathrm{pH}$ ниже 6,0 активность грибов преобладает над активностью бактерий, что наблюдается в большей степени в прибрежных районах.

В прибрежных районах моря, подверженных хроническому загрязнению нефтью, углеводородокисляющие бактерии наиболее многочисленны и достигают $10 \%$, а вдали от источников поступления нефти их только 0,01 \% от численности всего микробиоценоза. 
Ввиду особенностей механизмов биогенного и химического окисления, ряды устойчивости углеводородов разных классов в этих процессах не совпадают.

Так, микроорганизмы, содержащиеся в морской воде, потребляют сначала n-алканы, что приводит к относительному увеличению содержания в воде разветвленных алканов и ароматических соединений. Затем начинается предпочтительное потребление ароматических соединений.

Таким образом, скорость биодеградации углеводородов изменяется в порядке: алканы > ароматические углеводороды > циклопарафины, а скорость химического окисления, например, у алканов меньше, чем у парафинов, тогда как у ароматических углеводородов она больше, чем у циклопарафинов. Нефтяные вещества сорбируются почвами преимущественно в жидкой фазе, и сначала происходит сорбция полярных компонентов нефтяных веществ (нафтеновые кислоты, смолы, асфальтены). Способность углеводородов сорбироваться породами понижается в последовательности: олефины > ароматика > циклопарафины > парафины.

Количество сорбированных нефтяных углеводородов в единице объема грунта зависит от общего свободного объема капилляров (гранулометрического состава) и влажности самого грунта.

\section{5. Химические процессы при деградации нефти в гидросфере}

Будучи высокоорганизованной субстанцией, состоящей из множества соединений, нефть деградирует очень медленно. Однако нефть и нефтепродукты, попавшие в водную среду, подвергаются многочисленным процессам, направленным на ее разрушение.

Таким образом, миграция нефти и нефтепродуктов в водной среде осуществляется в растворенной, эмульгированной и пле- 
ночной формах, а также в виде агрегатов. Исследование геохимии нефтезагрязненных водных геосистем показало, что в результате физических, химических и биологических процессов деградация нефти носит многоэтапный характер и характеризуется последовательным изменением эколого- геохимических характеристик. Можно сказать, что трансформация нефти протекает через реакции гидрирования, дегидрирования, гидроксилирования, оксосинтеза, карбоксилирования, декарбоксилирования, эстерификации, гидролиза, конденсации, совокупность которых приводит к деградации углеродного субстрата [368,369].

Так, первичная реакция дегидрирования алканов приводит к образованию алкенов, окисление которых через окиси, спирты и кетосоединения приводит к кислотам. Кислоты через реакцию декарбоксирования образовывают алканы или, взаимодействуя со спиртами, дают сложные эфиры. При последующем окислении кислот приводит к образованию полифункциональных соединений, склонных к реакциям конденсации, в том числе и с сингенетичной органикой. Моноциклические углеводороды, будучи окисленными до кетонов, способны к разрыву кольца с образованием соответствующих насыщенных и ненасыщенных карбоновых кислот [368-370]. Процессу гидролиза подвергаются соединения, являющиеся слабыми кислотами или основаниями, эфиры, амиды различных карбоновых и фосфорсодержащих кислот.

Таким образом, при деградации нефти образуются непредельные соединения: алкены, непредельные кислоты и эфиры непредельных кислот, которые с компонентами нефти или с сингенетичной органикой морей могут дать реакции конденсаци. Реакции присоединения нуклеофилов по активированной двойной углерод-углерод связи широко известны под названием реакции (конденсации) Микаэля [201]. В роли нуклеофилов могут быть амины, меркаптаны, спирты, СН кислоты и т.д.

$$
\mathrm{CH}_{2}=\mathrm{CHCONHX}+\left(\mathrm{C}_{n} \mathrm{H}_{\mathrm{m}}\right)_{2} \mathrm{NH} \rightarrow\left(\mathrm{C}_{\mathrm{n}} \mathrm{H}_{\mathrm{m}}\right)_{2} \mathrm{NCH}_{2}-\mathrm{CH}_{2} \mathrm{CONHX} .
$$


Содержание азота в нефти редко превышает 1\% [4]. Обычно азотсодержащие соединения нефти делят на две большие группы: азотистые основания и нейтральные азотистые соединения. Амины основного характера представлены преимущественно третичными аминами - производными пиридина, хинолина, изохинолина, в меньшей степени акридина. Значительно реже представлены гомологи анилина. Алкиламины в нефти не обнаружены. Нейтральные азотсодержащие соединения нефти представлены арилпроизводными пиррола, индола, карбазола, бензокарбазола и амидами предельных и непредельных кислот [4,45].

Надо отметить, что амины присутствуют не только в нефти, они также образуются в гидросфере в результате гидролиза белков, фосфолипидов и прямым дезаминированием аминокислот [78]. Фосфолипиды являются сложными эфирами многоатомных спиртов, но у них, в отличие от жиров, одна из спиртовых групп связана не с жирной, а с фосфорной кислотой, которая в свою очередь связана эфирными связями с азотистым основанием или аминокислотой [371]. Например, глицерофосфолипиды с метилэтаноламином: Фосфатидин $\mathrm{N}$ - метил этаноламин, при гидролизе которого образуется моноэтаноламин.

Деградация нефти и нефтепродуктов осуществляется также путем химического окисления, и скорость этого процесса зависит от условий среды. Процессы окисления одних структур ингибируются другими, трансформация отдельных соединений идет по пути образования форм, в дальнейшем плохо окисляемых. Так, некоторая часть нефтяных углеводородов может разлагаться в процессе автокаталитического окисления по свободнорадикальной цепной реакции, завершающейся образованием гидроперекисей, а продукты разложения последних служат инициаторами дальнейшего окисления углеводородов. Процесс окисления нефти стимулируется металлосодержащими соединениями нефтей и инициируется действием солнечной радиации. Так, в ясную погоду может окислиться до 2 т/км² нефти за сутки. Окисление 
нефти в водных экосистемах ингибируется белками, аминами, фенолами, серосодержащими соединениями и аминами.

Фотохимические превращения загрязняющих веществ осуществляются в природной среде под действием ультрафиолетовой составляющей ( $\lambda=310$ нм) при участии свободных радикалов - соединений, имеющих неспаренный электрон, находящихся в возбужденном состоянии. Свободно радикальный механизм трансформации загрязняющих соединений в водной среде наиболее характерный механизм самоочищения в водоемах в результате фотохимических и биохимических реакций.

\subsection{1. Конденсация Михаэля в двухфазной системе}

Таким образом, нефть, попадая в водную среду естественных водоемов, будучи нерастворимой в воде, образует двухфазную систему нефть-вода и реакции трансформации нефти, в основном, протекают на границе раздела фаз нефть-вода и в эмульсиях, то есть протекают реакции межфазного катализа. Межфазный катализ впервые предложен Старксом [372], часто используют для реакции нуклеофильного замещения с участием, например, алкилгалогенидов:

$$
\mathrm{RX}+\mathrm{MY} \rightarrow \mathrm{RY}+\mathrm{MX},
$$

где RX - алкилгалогенид, MY - соль, с использованием четвертичных аммонийных солей $\left(\mathrm{R}_{4} \mathrm{NX}\right)$, которые не обладают поверхностной активностью, играющих роль межфазных катализаторов. Применение этого метода имеет свои ограничения. Одно из них связано с тем, что только анионы переходят из водной фазы (ВФ) в органическую (ОФ), где и протекает реакция. Следует еще раз подчеркнуть,что основной средой реакции является не вода, а органическая фаза.

Второй тип межфазного катализа - это предложенный Матиасом и Ваида [373] - обращенный межфазный катализ 
(ОМФК), (Inverse Phase Transfer Catalysis), при котором субстрат из ОФ переходит в ВФ. Буае, Роком и сотр. [374] была разработана новая методология, которая может быть в принципе применена для очень широкого класса органических реакций. Это чистый ОМФК. Идея заключается в использовании двухфазной системы, одной из которых является вода, содержащая ПАВ в количествах чуть больше ККМ в качестве переносчика субстрата из ОФ в ВФ, где находится водорастворимый реагент. При изучении влияния скорости перемешивания в присутствии ПАВ авторами работ [375] установлено новое явление: при высоких скоростях перемешивания двухфазная система превращается во временную квазистабильную эмульсию. При этом скорость эпоксидирования увеличивается почти на два порядка. После остановки перемешивания система вновь становится двухфазной. Это явление названо межповерхностным катализом (МПК), (Interface Catalysis) [375].

Здесь имеются два варианта: первый - НС растворимо в ОФ, но практически не растворимо в воде, а вторичный амин растворим в воде, но не растворим в ОФ, второй - НС растворимо в воде, а вторичный амин в воде практически не растворим.

Ниже приведены данные изучения в модельной системе «нефть- вода» реакций между жирорастворимым бутилакрилатом (БА) и водорастворимым диэтаноламином (ДЭолА) [56,205,206,376-383] и жирорастворимыми аминами: дипропиламин (ДПА), дибутиламин (ДБА), гексиламин (ГА), дециламин (ДА) и тетрадециламин (ТДА) и водорастворимыми НС: N[три(гидроксиметил)метил]акриламид (ТА) и акриламид (АА) [87,205,374,383-388] в двухфазной системе гептан - вода в отсутствие и в присутствии ПАВ. Также конденсация ацетоуксусного эфира (АУЭ) с АА и $\alpha$-метилакриламидом (МАА) в воднощелочном растворе в присутствии четвертичных аммониевых солей [389,390]. 


\subsubsection{1. Кинетические закономерности реакции БА+ДЭолА в двухфазной системе гептан - вода}

Кинетические исследования при малых скоростях перемешивания $\left(\mathrm{W}_{\text {пер}}\right.$ ) (до 500 об/мин.) показали,что начальная скорость реакции БА + ДЭолА до [БА] < 2 моль/л в двухфазной системе вода-гептан описывается уравнением

$$
\mathrm{W}_{0}=\mathrm{k}[\text { БА }]_{0}[\text { ДЭолА }]_{0} \text {. }
$$

Как видно из таблицы 6.1, при [БА] > 2 моль/л скорость реакции становится независимой от концентрации БА.

Таблица 6.1.

Влияние начальной конщентрации БА на скорость реакиии БА+ДЭолА в системе $\mathrm{H}_{2} \mathrm{O}$ - гептан при условиях: [ДЭолА] $=1.0$ моль/л, $T=293 \mathrm{~K}$, $W_{\text {nер }}=500$ об/мин, $S=2 \mathrm{~cm}^{2}$.

\begin{tabular}{|c|c|c|c|c|c|c|c|}
\hline$[\text { БА }]_{0}$,моль/л & 0,5 & 1,0 & 1,5 & 2,0 & 2,5 & 4,0 & 6,8 \\
\hline $10^{6}$. $\mathrm{W}$,моль л- ${ }^{-}{ }^{-}-{ }^{1}$ & 4,9 & 9,2 & 14,0 & 20,0 & 20,5 & 20,5 & 20,5 \\
\hline
\end{tabular}

Изучение распределения БА в системе вода - гептан при $\mathrm{T}=293 \mathrm{~K}$ показало, что с повышением концентрации БА до 2 моль/л вода насыщается БА-ом (растворимость последнего в воде увеличивается до $0.2 \%$ ) и при [БА] >2 моль/л концентрация БА в воде остается постоянной. Энергия активации составляет $35 \pm 2$ кДж.моль ${ }^{1}$. Она определялась при условиях $\mathrm{T}=293-323 \mathrm{~K}_{\text {и }}$ $[\text { БА }]_{0}=[\text { ДЭолА }]_{0}=1,0$ моль/л.

Как было показано, скорость гомогенной реакции БА+ДЭолА в ДМФА также описывается уравнением второго порядка. Таким образом, из экспериментальных данных следует, что при малых скоростях перемешивания порядок реакции БА+ДЭолА один и тот же и не зависит от того, является система гомогенной или гетерогенной (двухфазной), т.е. механизм реакции не меняется. 
Полученные кинетические данные удовлетворяют схеме реакции $\mathrm{HC}$ с $\mathrm{R}_{2} \mathrm{NH}$ [201].

Как отмечалось в работах [374,375], при эпоксидировании жирорастворимого НС водорастворимым НОO- в среде вода гептан в качестве межфазного переносчика были использованы неионные, анионные и катионные ПАВ. Наилучший результат был получен при использовании катионактивного ПАВ - бромилдодецилтриэтиламония (ДТАБ). При исследовании реакции БА+ДЭолА в среде вода - гептан в присутствии неионного (ОС20), анионного(Е-30) и катионного ДТАБ ПАВ также получен наилучший результат в присутствии ДТАБ, поэтому будет обсуждаться только влияние последнего. Этого можно было ожидать, так как ДТАБ, будучи растворимым в воде, будет способствовать переносу БА из гептана в ВФ, где скорость реакций НС +вторичный амин (нуклеофил) наибольшая.

Таблица 6.2. Влияние начальной концентрации ДТАБ на скорость реакции БА+ДЭолА в

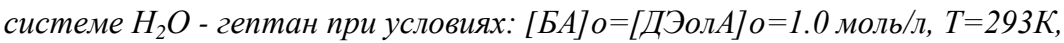

$$
W_{\text {nep }}=500 \mathrm{oб} / \mathrm{Muн}, S=2 \mathrm{~cm}^{2} \text {. }
$$

\begin{tabular}{|c|c|c|c|c|c|c|c|c|}
\hline $\begin{array}{c}10^{2}[\text { [ДТАБ }]_{0}, \\
\text { моль } / \text { л }\end{array}$ & 0 & 0,16 & 0,32 & 0,65 & 1,3 & 1,6 & 3,2 & 10 \\
\hline $10^{6} \mathrm{~W}$,моль л- ${ }^{\mathrm{I}} \mathrm{c}-{ }^{1}$ & 9,2 & 9,8 & 10,4 & 11,6 & 14 & 15 & 15 & 15 \\
\hline
\end{tabular}

Как видно из данных,приведенных в таблице 3.2, при малых скоростях перемешивания, когда система остается двухфазной, с повышением [ДТАБ] д до $1,5.10^{-2}$ моль/л, скорость реакции увеличивается симбатно с увеличением концентрации ДТАБ, а выше этой концентрации влияние последней не так ощутимо.

Когда ПАВ отсутствует, реакция протекает на границе раздела фаз(РФ) вода-гептан. Когда в системе присутствует ДТАБ в концентрациях меньше, чем ККМ (ККМ $=1.4 .10^{-2}$ [391]), вместо поверхности $\mathrm{S}$ ( $\mathrm{S}$ - это поверхность РФ, что совпадает с сечением цилиндрического реактора) на границе РФ получается объём, 
который образуется молекулами ПАВ, адсорбированными на поверхности РФ. При этом полярные группы ПАВ погружены в ВФ, а его гидрофобные хвосты - в ОФ. Этот объем насыщен и БА и ДЭолА, что приводит к повышению скорости в результате увеличения концентраций как БА, так и ДЭолА в данной зоне. Когда [ДТАБ] $>$ К ККМ, в водной фазе образуются мицеллы, в которых солюбилизуется БА. Таким образом, концентрация БА повышается в водной фазе и, кроме того, реакция протекает также в мицеллах - в новой реакционной зоне. Микроокружение в мицеллах своеобразное, кроме того свойства объемной воды отличаются от свойств воды, находящейся в мицеллярной фазе. Как видно из таблицы 6.3 (столб. I), в отсутствии ДТАБ с повышением скорости перемешивания скорость реакции БА+ДЭолА симбатно увеличивается вследствие увеличения скорости диффузии БА в ВФ, приводящей к росту концентрации БА в воде - в реакционной зоне (скорость реакции увеличивается от $3.8 \cdot 10^{-6}$ л моль ${ }^{-1} \mathrm{c}^{-1}$ при $\mathrm{W}_{\text {пер}}=100$ об/мин, до $21 \cdot 10^{-6}$ л моль $^{-1} \mathrm{c}^{-1}$ при $\mathrm{W}_{\text {пер}}=1400$ об/мин).

Таблица 6.3.

Влияние скорости перемешивания на скорость реакиии БА ДЭолА в

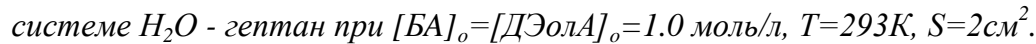

\begin{tabular}{|c|c|c|c|c|}
\hline \multirow[t]{3}{*}{$\mathrm{W}_{\text {пер }}$, об/мин. } & \multicolumn{4}{|c|}{$10^{6} \mathrm{~W}$, моль $\pi^{-1} \mathrm{c}^{-1}$} \\
\hline & \multicolumn{2}{|c|}{ [ДТАБ] =0 моль/л } & \multicolumn{2}{|c|}{ [ДТАБ] $=0.1$ моль/л } \\
\hline & I & II & III & IV \\
\hline 0 & 3.8 & 12 & 4.1 & 30.5 \\
\hline 100 & 5.2 & 13.5 & 6.3 & 27.7 \\
\hline 300 & 7.5 & 16.8 & 10.5 & 26.0 \\
\hline 500 & 8.7 & 18.2 & 14.8 & 25.6 \\
\hline 800 & 14 & 25.3 & 33 & - \\
\hline 1000 & 17.5 & 27.7 & 52 & - \\
\hline 1200 & 19 & 31.2 & 119 & - \\
\hline 1400 & 21 & 31.4 & 210 & - \\
\hline
\end{tabular}


Это предположение подтверждается при исследовании влияния площади межфазной поверхности $(\mathrm{S})$ на скорость реакции (таблица 6.4). С увеличением $\mathrm{S}$ скорость реакции симбатно увеличивается.

Таблица 6.4.

Влияние $\mathrm{S}$ на скорость реакиии БА+ДЭолА в системе $\mathrm{H}_{2} \mathrm{O}$ - гептан при

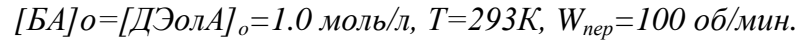

\begin{tabular}{|c|c|c|c|c|c|c|}
\hline $\mathrm{S}, \mathrm{cм}^{2}$ & 2 & 4 & 6 & 8 & 10 & 12 \\
\hline $10^{6} \mathrm{~W}$, моль л- $^{1}{ }^{1}-{ }^{1}$ & 5.2 & 7.3 & 9.5 & 12.0 & 14.1 & 17 \\
\hline
\end{tabular}

Влияние скорости перемешивания на скорость реакции в присутствии ДТАБ оказалось сложнее. Как видно из таблицы 6.3

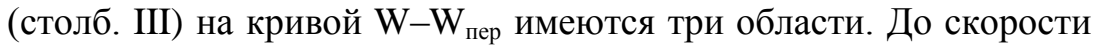
перемешивания 500 об/мин скорость реакции БА+ДЭолА увеличивается не так резко и система двухфазная, а при Wпер > 800 об./мин скорость реакции БА+ДЭолА увеличивается очень резко (от 33.10-6 л моль ${ }^{-1} \mathrm{c}^{-1}$, при $\mathrm{W}_{\text {пер}}=800$ об/мин, до 210.10-6 л моль ${ }^{-1} \mathrm{c}^{-1}$, при $\mathrm{W}_{\text {пер}}=1400$ об/мин и система преобразовывается в неустойчивую эмульсию. В области скорости перемешивания 500-800 об/мин имеем смешанный механизм, то есть система не двухфазная и не эмульсия.

Следует отметить, что выбранные нами концентраци ДТАБ не достаточны для получения стабильной эмульсии. После прекращения смешивания эмульсия спадается, и вновь образуются отдельные фазы. Согласно нашим кинетическим данным, при больших скоростях перемешивания в присутствии ДТАБ скорость реакции БА+ДЭолА в двухфазной среде вода - гептан увеличивается почти на два порядка. Как отмечалось, такое же явление наблюдается и при эпоксидировании бензилиденацетофенона анионом $\mathrm{HOO}^{-}[375]$.

Как видно из таблицы 6.5 , при $\mathrm{W}_{\text {пер }}=1400$ об/мин увеличение концентрации ДТАБ приводит к увеличению скорости реакции БА+ДЭолА. Оно объяснялось тем, что при интенсивном переме- 
шивании образуются сравнительно мелкие капельки с очень развитой поверхностью раздела, в результате чего общая скорость реакции увеличивается. Следует отметить,что концентрация ДТАБ влияет и на процент превращения продукта реакции (табл. $6.5)$.

Таблий 6.5.

Влияние [ДТАБ] $]_{0}$ на скорость реакиии БА+ДЭолА в системе $\mathrm{H}_{2} \mathrm{O}$ - гептан и прочент превращения при [БА]о=[ДолЭА] $=1.0$ моль $/ л, T=293 \mathrm{~K}, W_{\text {пер }}=1400$ об/мин, $S=2 \mathrm{~cm}^{2}$.

\begin{tabular}{|l|l|l|l|l|l|l|}
\hline [ДТАБ $]_{0}$, моль/л & 0 & 0,05 & 0,1 & 0,2 & 1,0 & $\begin{array}{l}{[\mathrm{E}-30]_{0}=0,1} \\
\text { моль/л }\end{array}$ \\
\hline $10^{4} \mathrm{~W}_{\text {,моль }}{ }^{-1} \mathrm{c}^{-1}$ & 0,21 & 1,4 & 2,1 & 2,5 & 3,3 & 0,32 \\
\hline \% превращ.после 4 ч & 34 & 81 & 90 & 92 & 98 & 45 \\
\hline
\end{tabular}

Таким образом, для реакции БА+ДЭолА в двухфазной системе вода-гептан получается:

$\mathrm{W}=\mathrm{k}[\text { БА }]_{0} \cdot[\text { ДЭолА }]_{0} \cdot[Д Т А Б]_{0}$, когда $[Д Т А Б]_{0}<\mathrm{KКМ,}$ где $\mathrm{k}=\mathrm{f}\left(\mathrm{S}, \mathrm{W}_{\text {пер }}\right)$.

Наблюдается интересное явление: при $10 \%$ конверсии реакция самоускоряется (рис. 3.1). 


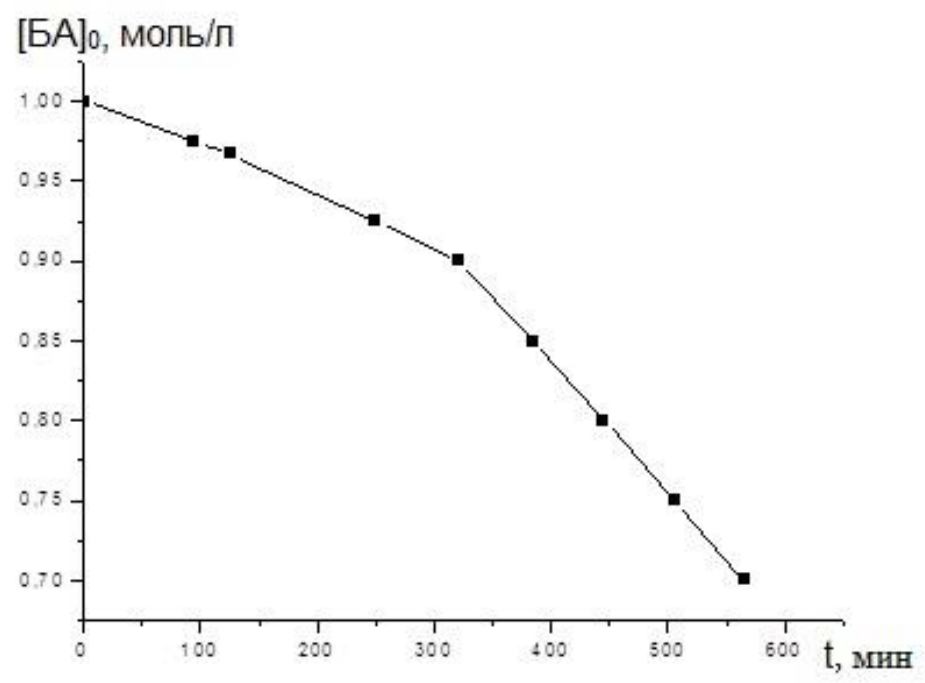

Рис.6.1. Кинетическая кривая расхода БА при реакиии БА с ДЭолА в системе $\mathrm{H}_{2} \mathrm{O}$ - гептан при [ДЭолА] $=1,0$ моль/л, $T=293 \mathrm{~K}, W_{\text {пер }}=100$ об/мин, $S=2 \mathrm{~cm}^{2}$.

Ускорение более ощутимо при малых скоростях перемешивания (табл.6.3,столб.II и IV). Установлено, что продукт реакции обладает значительной поверхностной активностью. Его ККМ=0.1 моль/л. Таким образом, по ходу процесса двухфазная система превращается в эмульсию. Это новый случай автокатализа.

Таким образом показано, что продукты трансформации нефти могут подвергатся конденсации Михаэля. Это может привести к удалению некоторых продуктов трансформации с поверхностного слоя и в последующем способствовать их обезвреживанию. 


\subsubsection{2. Кинетические закономерности реакции водорастворимое НС + амин в двухфазной системе гептан - вода}

В качестве водорастворимого НС нами выбраны АА и ТА, которые по своей реакционной способности в реакциях со вторичными аминами уступают только АН и МА.

Распределение НС и вторичных аминов по фазам является важным обстоятельством, предопределяющим те основные фазы или зоны, в которых протекание химических реакций более вероятно. Спектроскопические исследования показали, что АА и ТА из водной фазы практически не переходят в гептановую. В качестве жирорастворимых аминов выбраны ДБА и первичные амины: ДА и ТДА. Для лучшего понимания кинетики и механизма процесса в двухфазной системе вода-гептан и определения влияния продуктов реакции $\mathrm{HC}+$ амин на этот процесс изучены также в воде малорастворимые амины, например, ДПА и первичный амин: гексиламин(ГА) [375,376] .

Методом УФ спектроскопии определены коэффиценты распределения аминов Кр = Сгептан/ Свода в системе вода - гептан при соотношениях фаз 1:1 [392] (табл. 6.6). Как видно из табл. 6, $10 \%$ ДПА находится в воде, а $90 \%$ в гептане.

Таблица 6.6. Коэффииенты распределения аминов в системе вода-гептан при $T=293$ К.

\begin{tabular}{|l|c|c|c|c|c|}
\hline Амин & ДПА & ГА & ДБА & ДА & ТДА \\
\hline $\mathrm{Kp}$ & 0.11 & 0.20 & $6 \cdot 10^{-4}$ & $4 \cdot 10^{-4}$ & $6.8 \cdot 10^{-5}$ \\
\hline
\end{tabular}

Как видно из таблицы 3.7, скорости реакций ТА+ДПА и АА+ДПА в двухфазной системе вода-гептан почти одинаковы, однако в гомогенных условиях скорость реакции АА+ДПА в воде почти 2,3 раза больше скорости реакции ТА+ДПА. В отсутствие ДТАБ при увеличении скорости перемешивания скорость реак- 
ции АА с ДПА увеличивается почти в 3,8 раза, а скорость реакции ТА с ДПА увеличивается приблизительно в 2 раза, а в случае реакции ТА + ГА -в 1,5 раза.

Таблица 6.7.

Влияние [ДТАБ] о и (W $W_{\text {пер }}$ об/мин) на скорость реакциии ТА + Амин $\left(W_{1}\right)$ и $\mathrm{AA}+$ Амин $\left(\mathrm{W}_{2}\right)$ в системе $\mathrm{H}_{2} \mathrm{O}$ - гептан при $[\mathrm{HC}]_{o}=[\text { Амин }]_{o}=1.0$ моль/л, $T=293 K, S=2 \mathrm{~cm}^{2}$.

\begin{tabular}{|c|c|c|c|c|c|c|c|c|}
\hline \multirow[t]{3}{*}{ Скорость реакции } & \multicolumn{4}{|c|}{ [ДТАБ $]=0$} & \multicolumn{4}{|c|}{ [ДТАБ] = 0.1 моль/л } \\
\hline & \multicolumn{2}{|c|}{ ДПА } & \multicolumn{2}{|c|}{$\Gamma A$} & \multicolumn{2}{|c|}{ ДПА } & \multicolumn{2}{|c|}{$\Gamma \mathrm{A}$} \\
\hline & 100 & 1400 & 100 & 1400 & 100 & 1400 & 100 & 1400 \\
\hline $10^{4} \mathrm{~W}_{1}$, моль $\pi^{-1} \mathrm{c}^{-1}$ & 1,4 & 2,7 & 2,0 & 3,0 & 2,1 & - & 2,5 & - \\
\hline $10^{4} \mathrm{~W}_{2}$, моль л $\mathrm{J}^{-1} \mathrm{c}^{-1}$ & 1,3 & 4,9 & - & - & 1,8 & - & - & - \\
\hline
\end{tabular}

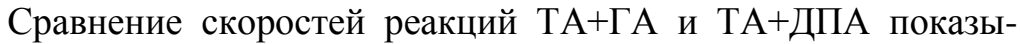
вает, что в отсутствии ДТАБ скорость реакции ТА+ГА в двухфазной системе вода-гептан в 1,5 раза больше скорости реакции ТА+ДПА, в то время, как в гомогенных условиях в растворе ФА

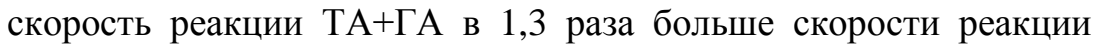
ТА+ДПА. Все это наводит на мысль, что продукты реакций

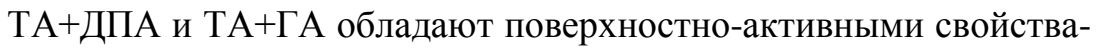
ми. Исследования показали, что продукты реакции ТА +ПП, МФ, ДЭА, ДПА и ГА являются неионными ПАВ [393]. Наиболее поверхностноактивным является ГАТПА.

Исследования показывали, что скорость реакции АА+ДБА при [ДБА] $>1$ моль/л становится независимой от концентрации ДБА [395]. Изучение распределения ДБА в системее вода-гептан при $\mathrm{T}=293$ К показало, что до концентрации [ДБА]=1моль/л, растворимость последнего в воде увеличивается до $0,15 \%$ и остается постоянной. Надо отметить, что кинетические закономерности реакции АА+ДБА в двухфазной системе аналогичны кинетическим закономерностям реакции БА +ДЭолА. Однако в присутствии 0.1 моль/л ДТАБ $\left(\mathrm{W}_{2}\right)$ и при больших скоростях перемешивания увеличение скорости реакции не так ощутимо. Это 
объясняется тем, что продукт реакции АА+ДБА, является неионным ПАВ, которое эмульгирует систему, и получается более устойчивая эмульсия, чем при тех же условиях при реакции БА+ДЭолА.

Таблица 6.8 . Влияние скорости перемешивания на скорость реакиии АА с ДБА в системе вода - гептан, $[\text { АА }]_{0}=[Д Б А]_{0}=1.0$ моль $/ л, T=293 \mathrm{~K}, S=2 \mathrm{~cm}^{2}$.

\begin{tabular}{|l|c|c|c|c|c|c|c|c|}
\hline \multicolumn{1}{|c|}{$\mathrm{W}_{\text {пер }}$ об/мин. } & 0 & 100 & 300 & 500 & 800 & 1000 & 1200 & 1400 \\
\hline $\begin{array}{l}10^{5} \mathrm{~W}_{1}, \\
\text { моль л }{ }^{-1} \mathrm{c}^{-1}\end{array}$ & 1.9 & 2.1 & 2.5 & 2.8 & 3.2 & 3.4 & 3.7 & 4.0 \\
\hline $\begin{array}{l}10^{5} \mathrm{~W}_{2}, \\
\text { моль л }\end{array} \mathrm{c}^{-1}$ & 2.4 & 2.6 & 3.0 & 3.4 & 4.1 & 5.6 & 6.8 & 8.0 \\
\hline
\end{tabular}

Очень интересный случай представляет реакция ТА-ДА в двухфазной системе [386-388]. Продукт реакции: ДАТПА не растворяется и в воде и в гептане и по ходу реакции, с увеличением его концентрации при малых скоростях перемешивания, ДАТПА распределяется между водой и гептаном. Получается «Химический сендвич».

Кинетические закономерности реакции ТА+ТДА в двухфазной системе аналогичны кинетическим закономерностям реакции БА+ДЭолА. Показано, что начальная скорость реакции ТА + ДА в двухфазной системе вода-гептан описывается уравнением:

$$
\mathrm{W}_{0}=\mathrm{k}[\mathrm{TA}]_{0}[Д A]_{0} .
$$

Как видно из таблицы 6.9, с увеличением S (совпадающая с сечением цилиндрического реактора) скорость реакции симбатно увеличивается.

Таблица 6.9.

Влияние $S$ на скорость реакиии ТА с ДА в системе вода - гептан при $[\text { ТА }]_{0}=[Д А]_{0}=1.0$ моль/л, $T=293 \mathrm{~K}, W_{\text {пер }}=100$ об./мин.

\begin{tabular}{|c|c|c|c|c|c|}
\hline $\mathrm{S}$, см $^{2}$ & 2 & 4 & 6 & 8 & 10 \\
\hline $10^{6} \mathrm{~W}$, моль л $^{-1} \mathrm{c}^{-1}$ & 1.0 & 1.8 & 2.9 & 3.7 & 4.4 \\
\hline
\end{tabular}


По приблизительным оценкам, скорость перемещения нефтяных пленок составляет 60\% от скорости течения и $2-4 \%$ от скорости ветра [360]. Как видно из таблицы 3.10, при повышении скорости перемешивания, скорость реакции ТА с ДА увеличивается.

Таблица 6.10.

Влияние скорости перемешивания на скорость реакции ТА с ДА в системе

\begin{tabular}{|c|c|c|c|c|c|c|c|}
\hline $\mathrm{W}_{\text {пер }}$, об/мин. & 0 & 100 & 300 & 500 & 800 & 1000 & 1200 \\
\hline $10^{5} \mathrm{~W}_{1}$, моль л $^{-1} \mathrm{c}^{-1}$ & 0.9 & 1.0 & 1.3 & 1.6 & 2.0 & 2.3 & 2.5 \\
\hline $10^{5} \mathrm{~W}_{2}$, моль $\pi^{-1} \mathrm{c}^{-1}$ & 1.0 & 1.3 & 1.9 & 2.6 & 4.1 & 7.1 & 10 \\
\hline
\end{tabular}

Как видно из таблицы 6.10, с повышением скорости перемешивания начальная скорость реакции ТА с ДА $\left(\mathrm{W}_{1}\right)$ симбатно увеличивается вследствие увеличения скорости диффузии ДБА в водную фазу, приводящей к росту концентрации ДА в воде - в реакционной зоне (скорость реакции увеличивается от $1.010^{-5}$ моль/л с при $\mathrm{W}_{\text {пер }}=0$ об/мин, до $2.5 \cdot 10^{-5}$ моль/лс при $\mathrm{W}_{\text {пер}}=1200$ об/мин. При малых скоростях перемешивания продукт реакции ТА-ДА, который не растворяется в воде, и в гептане и по ходу реакции с увеличением его концентрации распределяется между водой и гептаном. Получается “химический сендвич”, при этом продукт реакции имеет фрактальную структуру.

Когда ДТАБ отсутствует, реакция протекает на границе раздела фаз вода-гептан. Когда [ДТАБ $]_{0}=0,1$ моль/л, в водной фазе образуются мицеллы, в которых солюбилизуется ДА. Таким образом, концентрация ДА повышается в водной фазе и, кроме того, реакция протекает также в мицеллах - в новой реакционной зоне. Микроокружение в мицеллах своеобразное, кроме того, свойства объемной воды отличаются от свойств воды, находящейся в мицеллярной фазе. Этого можно было ожидать, так как ДТАБ, будучи растворимым в воде, будет способствовать пере- 
носу ДА из гептана в воду, где скорость реакции Михаэля наибольшая [394].

Влияние скорости перемешивания на скорость реакции в присутствии ДТАБ оказалось сложнее. Как видно из табл.6.10 $\left(\mathrm{W}_{2}\right)$, до скорости перемешивания 500 об/мин начальная скорость реакции ТА с ДА увеличивается не так резко и система двухфазная, а при $\mathrm{W}_{\text {пер}}>800$ об./мин начальная скорость реакции увеличивается резко (от от $4.1 \cdot 10^{-5}$ моль/л с при $\mathrm{W}_{\text {пер }}=800$ об/мин, до $10 \cdot 10^{-5}$ моль/л'с при $\mathrm{W}_{\text {пер }}=1200$ об/мин). Это объясняется тем, что при интенсивном перемешивании образуются сравнительно мелкие капельки с очень развитой поверхностью раздела, в результате чего общая скорость реакции увеличивается. После прекращения смешивания эмульсия распадается и вновь образуются отдельные фазы. В области скорости перемешивания 500-800 об/мин имеем смешанный механизм, то есть система не двухфазная и не эмульсия. При больших скоростях перемешивания $\left(\mathrm{W}_{\text {пер}}=1200\right.$ об/мин) в присутствии ДТАБ до $10 \%$ превращения эмульсия нестабильная и начальная скорость реакции увеличается на порядок, а потом получается стабильная эмульсия и реакция останавливается. Однако, при этом образуется только моноаддукт реакции.

Кинетические закономерности реакции ТА+ТДА в двухфазной системе аналогичны кинетическим закономерностям реакции БА+ДЭолА. Продукт реакции: ТДАТПА растворим в гептане [388].

Как видно из таблицы 6.11 , в отсутствие ДТАБ с повышением скорости перемешивания, скорость реакции ТА+ТДА увеличивается вследствие увеличения скорости диффузии ТДА в ВФ, приводящей к росту концентрации ТДА в воде, т.е. в реакционной зоне. 
Таблий 6.11.

Влияние скорости перемешивания на скорость реакиии ТА+ТДА в системе $\mathrm{H}_{2} \mathrm{O}$-гептан при $[\text { ТА }]_{0}=[\text { ТДА }]_{0}=0,1$ моль $/ л, T=303 К, S=3 \mathrm{~cm}^{2}[Д Т А Б]_{0}=O\left(W_{1}\right)$, 0,0016 моль/л. $\left(W_{2}\right)$.

\begin{tabular}{|c|c|c|c|c|}
\hline $\mathrm{W}_{\text {пер, }}$ об/мин & 100 & 500 & 800 & 1200 \\
\hline $10^{8} \mathrm{~W}_{1}$, моль $\mathrm{J}^{-1} \mathrm{c}^{-1}$ & 2 & 5,3 & 7,3 & 9,7 \\
\hline $10^{8} \mathrm{~W}_{2}$, моль $\pi^{-1} \mathrm{c}^{-1}$ & 4 & 13,25 & 26,5 & 97 \\
\hline
\end{tabular}

Как видно из таблициы 6.12, с увеличением площади межфазной поверхности скорость реакции симбатно увеличивается.

Таблица 6.12.

Влияние межфазной площади на скорость реакиии ТА+ТДА в системе $\mathrm{H}_{2} \mathrm{O}$-гептан при $[\mathrm{TA}]_{0}=[\text { ТДА }]_{0}=0,1$ моль $/ л, T=313 \mathrm{~K}, \mathrm{~W}_{\text {пер }}=500$ об./мин.

\begin{tabular}{|c|c|c|c|c|}
\hline $\mathrm{S}$, см $^{2}$ & 2 & 2.5 & 3 & 4.7 \\
\hline $10^{8} \mathrm{~W}$, моль л \\
\hline
\end{tabular}

Влияние скорости перемешивания на скорость реакции ТА+ТДА в присутствии ДТАБ оказалось сложнее. До скорсти перемешивания 500 об/мин система двухфазная, и скорость реакции увеличивается не так резко, а при $\mathrm{W}_{\text {пер }}>800$ об./мин, скорость реакции ТА+ТДА увеличивается очень резко (от 26,5 $10^{-}$ 8 л моль-1с-1, при Wпер=800 об/мин до $97.10-8$ л моль-1c-1, при $\mathrm{W}_{\text {пер}}=1200$ об/мин) и система превращается в эмульсию. В области 500< $\mathrm{W}_{\text {пер }}>800$ об/мин система не двухфазная и не эмульсионная, то есть имеем смешанный механизм.Надо отметить, что при всех скоростях перемешивания с повышением [ДТАБ]。 до $1,6.10^{-3}$ моль/л. скорость реакции увеличивается симбатно с увеличением концентрации ДТАБ, а выше этой концентрации по ходу образования продукта реакции система преобразуется в стабильную эмульсию(особенно при больших скоростях перемешивания). 


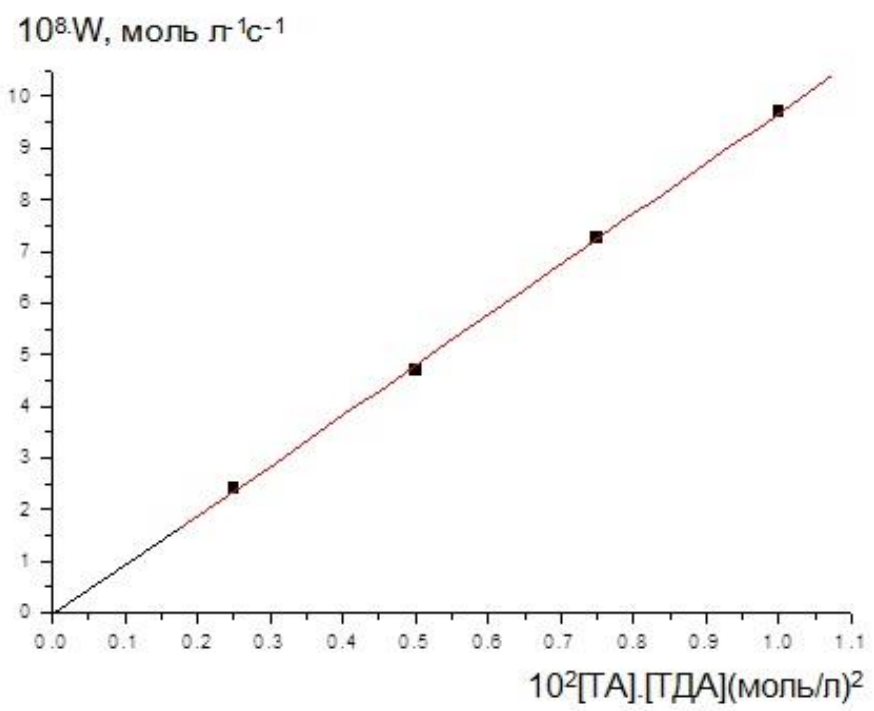

Рис.6.2. Влияние произведения [ТА] [ТДА] на скорость реакичии ТА+ТДА в системе $\mathrm{H}_{2} \mathrm{O}$ - гептан при $\mathrm{T}=313 \mathrm{~K}, \mathrm{~W}_{\text {nер }}=1200 \mathrm{oб} / \mathrm{muн}, \mathrm{S}=3 \mathrm{~cm}^{2}$

Как видно из рисунка 6.2, суммарный порядок реакции ТА +ТДА в системе вода-гептан второй, а по компонентам- первый. $\mathrm{W}=\mathrm{k}[\mathrm{TA}]_{0}[\text { ТДА }]_{0}[\text { [ДДТМАБ }]_{0}$, когда $[\text { ДТАБ }]_{0}<1,6.10^{-3}$ моль/л, где $\mathrm{k}=\mathrm{f}\left(\mathrm{S}, \mathrm{W}_{\text {пер }}\right)$.

Энергия активации составляет $44 \pm 2$ кДж.моль-1. Она определялась при условии Т=293-323 К и $[\text { ТА }]_{0}=[\text { ТДА }]_{0}=0,1$ моль/л, $\mathrm{S}=3 \mathrm{~cm}^{2}$ и $\mathrm{W}_{\text {пер }}=1200$ об/мин.

Сравнение скорости реакции ТА+первичный амин (ГА, ДА и ТДА) в двухфазной системе вода-гептан показывает (табл. 6.13), что по активности амины располагаются в ряд: ГА > ДА > ТДА. 
Таблица 6.13.

Константа скорости реакиии ТА +амин в системе $\mathrm{H}_{2} \mathrm{O}$-гептан при $T=293 K, W_{\text {пер }}=100$ об/мин, $S=2 \mathrm{~cm}^{2}$ и $K_{p}-$ коэффичиент распределения.

\begin{tabular}{|c|c|c|c|}
\hline Амин & ГА & ДА & ТДА \\
\hline $10^{6} \mathrm{k}$, л.моль $^{-1} \mathrm{c}^{-1}$ & 200 & 10 & 0,5 \\
\hline $\mathrm{K}_{\mathrm{p}}$ & 0,2 & $4 \cdot 10^{-4}$ & $6,8 \cdot 10^{-5}$ \\
\hline
\end{tabular}

Полученную закономерность можно объяснить тем, что с удлинением алкильного радикала в молекуле амина, во-первых, уменьшается растворимость и,следовательно, концентрация амина в водной фазе, во-вторых, стерически затрудняется протекание реакции ТА +амин.

\subsubsection{3. Реакции аминов с поверхностно - активными непредельными амидами кислот в модельной системе нефть - вода}

В рамках модели «нефть-вода» изучена кинетика реакций пиперидина (ПП), морфолина (МФ), диэтиламина (ДЭА), ДПА и метилэтаноламина (МЭА) с поверхностно-активными амидами непредельных кислот (ПАА): ТА, 4-акриламидобутаноат натрия (АБ), 6-акриламидогексаноат натрия (АГ) и 11-акриламидоундеканоат натрия (АУ) в воде и органических растворителях [384,395-393].

При изменении начальных концентраций ПАА изменяются не только коллоидно - химические свойства реакционной среды, но и структура самих ПАА [385]. Поэтому порядки и константы скорости реакций ПАА с аминами были определены с использованием данных о начальных скоростях в широких пределах концентраций реагентов:

$$
\begin{gathered}
{[\text { ТА }]_{0}=1.10^{-2} \div 1,5 \text { моль } \pi^{-1},[\text { АБ }]_{0} \text { и }[\text { АГ }]_{0}=1.10^{-2} \div 1,0 \text { моль. }{ }^{-1},} \\
{[\mathrm{AУ}]_{0}=10^{-2} \div 10^{-1} \text { моль. }{ }^{-1},[\mathrm{MЭА}]_{0}=1.10^{-2} \div 1,0 \text { моль.л }}
\end{gathered}
$$


Кинетические исследоапния показали, что исследуемая реакция подчиняется уравнению:

$$
\mathrm{W}_{0}=\mathrm{k}[\text { ПАА }]_{0} \cdot[\text { Амин }]_{0 .}
$$

Для ТА в концентрациионном интервале с $1.10^{-2}$ до 1,5 моль.л ${ }^{-1}$ константа скорости реакций ТА+Амин не зависит от $[\mathrm{TA}]_{0}$.

Так как мицеллообразующая способность остальных ПАА значительно больше, чем ТА (таблица 6.14), то это обстоятельство вызвало необходимость исследования влияния начальных концентраций этих ПАА на константу реакций с аминами выше и ниже значения критической концентраций мицеллообразования (ККМ). В виду того, что для АУ ККМ низка, то проведение кинетических исследований ниже ККМ практически невозможно, поэтому исследование велось только при [АУ] >> ККМ.

Таблий 6.14.

Константы скорости реакции ПАА+вторичный амин в воде, при $T=293 K$, [ПАА] $>$ >КМ и параметры, определяющие реакиионную способность ПАА.

\begin{tabular}{|c|c|c|c|c|}
\hline ПАА & TA & АБ & $\mathrm{A} \Gamma$ & AY \\
\hline $10^{4} \mathrm{k}_{\text {ПАА + ПП, }}$ Моль $^{-1}$ л $^{-1}$ & 120 & 20 & 26 & 24 \\
\hline $10^{4} \mathrm{k}_{\text {ПАА }+ \text { МЭА }}$, МОЛЬ $^{-1}$ Л $\mathrm{c}^{-1}$ & 33 & 5.1 & 7.3 & 6.0 \\
\hline $10^{4} \mathrm{k}_{\text {ПАА }+ \text { ДЭА }}$, МОЛЬ $^{-1}$ л $\mathrm{c}^{-1}$ & 18 & 3.0 & 3.9 & 3.2 \\
\hline $10^{4} \mathrm{k}_{\text {ПАА }+ \text { ДПА }}$, моль $^{-1}$ л $\mathrm{c}^{-1}$ & 16 & 2.9 & 3.7 & 3.1 \\
\hline $10^{4} \mathrm{k}_{\text {ПАА }+ \text { МФ }}$, моль $^{-1}$ л $^{-1}$ & 15 & 2.8 & 3.5 & 3.0 \\
\hline ККМ, моль.л ${ }^{-1}[388]$ & $\sim 1$ & 0.12 & 0.046 & 0.0007 \\
\hline $\mathrm{q} \beta \mathrm{c}$ & +0.07 & +0.054 & +0.049 & +0.058 \\
\hline $\mathrm{q}_{\mathrm{C} 0}$ & -0.361 & -0.356 & -0.386 & -0.36 \\
\hline
\end{tabular}

В таблице 6.15 приведены константы скорости реакций АБ+Амин и АГ+Амин при концентрациях ПАА ниже и выше ККМ. С ростом [ПАА $]_{0}$ константа скорости взаимодействия АБ и АГ с аминами уменьшается вплоть до достижения концентрации, 
равной ККМ, и сохраняется постоянной в более концентрирированных растворах (до 1 моль.л ${ }^{-1}$ ).

Постоянство констант скоростей реакции при [ПАА] > ККМ свидетельствует о том, что реакция протекает с участием мицелл АБ, АГ и АУ.

Таблица 6.15.

Влияние исходной концентраџии ПАА на константу скорости реакции ПАА + МЭА при $T=293 K$.

\begin{tabular}{|c|c|c|c|c|c|c|c|c|c|}
\hline $\begin{array}{l}{[\text { ПАА }]_{0},} \\
\text { моль' }^{-1}\end{array}$ & 0.01 & 0.025 & 0.05 & 0.075 & 0.1 & 0.2 & 0.5 & 0.75 & 1.0 \\
\hline $\begin{array}{l}10^{5} \mathrm{k}_{\mathrm{AБ}+\Pi \Pi} \\
\text { моль }^{-1} \text { л } \mathrm{c}^{-1}\end{array}$ & 24 & 24 & 23 & 22 & 21 & 20 & 20 & 20 & 20 \\
\hline $\begin{array}{l}10^{5} \mathrm{k}_{\mathrm{A \Gamma}+\Pi \Pi} \\
\text { моль }^{-1} \text { л } \mathrm{c}^{-1}\end{array}$ & 30 & 28 & 26 & 26 & 26 & 26 & 26 & 26 & 26 \\
\hline $\begin{array}{l}10^{5} \mathrm{k}_{\mathrm{AБ}}+\text { мЭА } \\
\text { моль }^{-1} \text { Л } \mathrm{c}^{-1}\end{array}$ & 55 & 55 & 55 & 53 & 52 & 51 & 51 & 51 & 51 \\
\hline $\begin{array}{l}10^{5} \mathrm{k}_{\mathrm{A} \Gamma+\mathrm{M} А \mathrm{~A}} \\
\text { моль }^{-1} \mathrm{c}^{-1}\end{array}$ & 77 & 75 & 73 & 73 & 73 & 73 & 73 & 73 & 73 \\
\hline $\begin{array}{l}10^{5} \mathrm{k}_{\mathrm{AБ}}+\text { ДЭА } \\
\text { моль }^{-1} \text { л }^{-1}\end{array}$ & 3.4 & 3.4 & 3.3 & 3.2 & 3.1 & 3.0 & 3.0 & 3.0 & 3.0 \\
\hline $\begin{array}{l}10^{5} \mathrm{k}_{\mathrm{A} Г}+\text { ДЭА } \\
\text { моль }^{-1} \mathrm{c}^{-1}\end{array}$ & 4.2 & 4.1 & 3.9 & 3.9 & 3.9 & 3.9 & 3.9 & 3.9 & 3.9 \\
\hline $\begin{array}{l}10^{5} \mathrm{k}_{\mathrm{AБ}+\mathrm{M} \Phi} \\
\text { моль }^{-1} \text { л } \mathrm{c}^{-1}\end{array}$ & 3.2 & 3.2 & 3.0 & 3.0 & 2.9 & 2.8 & 2.8 & 2.8 & 2.8 \\
\hline $\begin{array}{l}10^{5} \mathrm{k}_{\mathrm{AL}}+\mathrm{M \Phi} \\
\text { моль }^{-1} \text { л }^{-1}\end{array}$ & 4.2 & 3.9 & 3.7 & 3.5 & 3.5 & 3.5 & 3.5 & 3.5 & 3.5 \\
\hline
\end{tabular}

Для того, чтобы иметь адекватные кинетические данные и для сравнения реакционной способности ПАА по отношению к аминам, в таблице 6.14 приведены константы скоростей, полученные при [ПАА $]_{0}>$ ККМ, при которых в реакционной среде присутствуют мицеллы. Получается, что АБ, АГ и АУ, которые содержат гидрофобные группы, менее реакционно способны по отношению к аминам, чем ТА, содержащий три гидрофильных ОН групп. 
По реакционноспосбности в реакции с МЭА, ПАА располагаются в ряд: ТА > АБ $>$ АГ $>$ АУ.

Этот ряд не коррелируется с их ККМ.

В работе [393] показано, что выполняется корреляция между скоростями реакций ненасыщенных соединений (НС) (акрилонитрил, акриламид и метакриламид) со вторичными аминами и суммарного заряда на $\beta$-углеродного атома $\left(\mathrm{q}_{\beta \mathrm{C}}\right)$.

Как и для немицеллообразующих НС, реакционная способность ПАА, помимо других факторов, должна также зависеть от суммарного заряда $\beta$-углеродного атома. Корреляция $\operatorname{lgk}$ и $\mathrm{q}_{\beta \mathrm{C}}$ выполняется также для исследованных ПАА, за исключением АГ.

Исходя из механизма взаимодействия $\mathrm{HC}+$ вторичный амин, как и для немицеллообразующих НС, для характеризации активности мономера помимо $\mathrm{q}_{\beta \mathrm{C}}$ важен и заряд кислорода в фрагменте $\mathrm{CONH}\left(\mathrm{q}_{\mathrm{co}}\right)$. Приняв ККМ как меру ассоциативности ПАА, нами предлагается эмпирическое уравнение, связывающее логарифм константы скорости реакции ПАА + Амин с q $\mathrm{q}_{\beta \mathrm{C}}$, qсо и ККМ ПАА.

$$
\operatorname{lgk}=\mathbf{a}_{0}+\mathbf{a}_{1} \mathbf{q}_{\beta C}+\mathbf{a}_{2} \mathbf{q}_{C O}+\mathbf{a}_{3} \text { KKM. }
$$

Несмотря на то, что число ПАА мало для корректного решения уравнения (оценка множественного коэффициента корреляции, среднеквадратического отклонения и т.д.), тем не менее оно позволяет хотя бы оценить вклад $\mathrm{q}_{\beta C}$, $\mathrm{q}_{\mathrm{CO}}$ и ККМ на скорость реакции ПАА - вторичный амин. Решение уравнения для реакций ПАМ+вторичный амин получается:

$$
\begin{aligned}
& \lg _{\text {ПАА }+\Pi \Pi}=-6.95+23.73 q_{\beta C}-8.19 q_{\text {CO }}+0.41 \text { ККМ } \\
& \operatorname{lgk}_{\text {ПАА }}+\text { ЭЭА }=-7.21+15.73 q_{\beta C}-7.78 q_{C O}+0.55 \text { ККМ }
\end{aligned}
$$

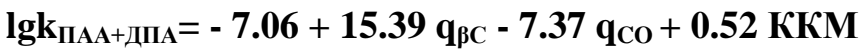

$$
\begin{aligned}
& \operatorname{lgk}_{\text {ПАA }+M \Phi}=-6.97+15.51 q_{\beta C}-7.06 q_{C O}+0.51 \text { ККМ } \\
& \operatorname{lgk}_{\text {ПАА }+ \text { МА }}=-6.96+19,63 q_{\beta C}-7,204 q_{C O}+0.456 \text { ККМ }
\end{aligned}
$$

Из уравнений следует, что чем больше положительный заряд на $\beta$-углероде и отрицательный заряд на кислороде, тем активнее 
ПАА взаимодействует со вторичными аминами. С увеличением ККМ, т.е. с уменьшением способности ПАА ассоциироваться, скорость реакции ПАА + Амин увеличивается.

Исходя из фактов, что в модельной системе «нефть-вода» присутствуют различные жидкие органические соединение и то, что в отличие от остальных ПАА ТА растворяется также в ДМФ, ДМСО и ФА, нами исследовано также влияние растворителя на скорость реакции ТА-МЭА. Из таблицы 6.16 следует, что растворители располагаются в ряд:

$$
\mathrm{H}_{2} \mathrm{O}>\text { ФА }>\text { ДМСО > ДМФА }
$$

Как и для реакции немицеллообразующих $\mathrm{HC}+$ вторичный амин [389], получается хорошая корреляция между $\operatorname{lgk}$ реакции ТА+Амин и электрофильностю растворителя - $\mathrm{E}_{\mathrm{T}}$ по ДимротуРайхарду [399], и параметром Симоняна - U[394] :

Так, для МЭА получается отличная корреляция:

$\operatorname{lgk}_{\mathrm{TA}+\mathrm{M} \ni}=(-10.256 \pm 0.502)+(0.106 \pm 0.010) \cdot \mathbf{E}_{\mathrm{T}}, \mathbf{R}^{2}=0.99198$.

$\operatorname{lgk}_{\mathrm{TA}+\mathrm{M} \ni \mathrm{A}}=(-5.670 \pm 0.116)+(0.816 \pm 0.045) \cdot \mathrm{U}, \mathrm{R}^{2}=0.99696$.

Таблица 6.16.

Константы скорости реакции ТА растворителях, при $T=293 K$.

\begin{tabular}{|c|c|c|c|c|}
\hline Растворитель & $\mathrm{H}_{2} \mathrm{O}$ & ФА & ДМСО & ДМФА \\
\hline $10^{4} \mathrm{k}_{\mathrm{TA}+\text { пП }}$, моль $^{-1} \cdot \mathrm{c}^{-1}$ & 120 & 13 & 1.4 & 1.3 \\
\hline $10^{4} \mathrm{k}_{\mathrm{TA}+\mathrm{M} \Phi}$, моль $^{-1} \mathrm{r}^{-1}$ & 15 & 1.6 & 0.1 & 0.085 \\
\hline $10^{4} \mathrm{k}_{\text {TА }+ \text { дэА }}$ моль ${ }^{-1} \cdot \mathrm{r}^{-1}$ & 18 & 2.0 & 0.17 & 0.14 \\
\hline $10^{4} \mathrm{k}_{\text {TА }+ \text { дПА }}$, моль $^{-1} \cdot \mathrm{r}^{-1}$ & 16 & 1.8 & 0.15 & 0.12 \\
\hline $10^{4} \mathrm{k}_{\mathrm{TA}+\text { мЭА }}$, моль $^{-1} \cdot \pi^{-1} \mathrm{c}^{-1}$ & 33 & 3.5 & 0.30 & 0.25 \\
\hline $\mathrm{E}_{\mathrm{T}}$ & 63.1 & 56.6 & 45.0 & 43.8 \\
\hline $\mathrm{U}$ & 3.824 & 2.852 & 1.387 & 1.276 \\
\hline
\end{tabular}

Таким образом, показано, что миграция нефти и нефтепродуктов в водной среде осуществляется в растворенной, эмульгированной и пленочной формах, а также в виде агрегатов. 
В процесе формирования эмульсии принимают участие компоненты нефти с высокой поверхностной активностью - нафтеновые и жирные кислоты, смолы, вещества с низкими поверхностно-активными свойствами, асфальтены. Исследование геохимии нефтезагрязненных водных геосистем показало, что в результате физических, химических и биологических процессов деградация нефти носит многоэтапный характер и характеризуется последовательным изменением эколого- геохимических характеристик. Можно сказать, что трансформация нефти протекает через реакции гидрирования, дегидрирования, гидроксилирования, оксосинтеза, карбоксилирования, декарбоксилирования, эстерификации, гидролиза, конденсации. Показано, что в трансформации нефти в гидросфере участвуют компоненты нефти и сингенетичные вещества гидросферы, в частности непредельные соединения и амины. Установлено, что нефть, попадая в водную среду естественных водоемов, будучи нерастворимой в воде, образует двухфазную систему нефть-вода и рекции трансформации нефти, в основном, протекают на границе раздела фаз нефть-вода и в эмульсиях, то есть протекают реакции межфазного катализа. В рамках модели «нефть-вода» обсуждаются кинетические закономерности конденсации Михаэля между жирорастворимым бутилакрилатом и водорастворимым диэтаноламином и жирорастворимыми аминами: дипропиламин, дибутиламин, гексиламин, дециламин и тетрадециламин и водорастворимыми непредельными соединениями: $\mathrm{N}$-[три(гидроксиметил)метил]акриламид и акриламид в двухфазной системе гептан - вода. 


\subsubsection{4. Реакция эфира ацетоуксусной кислоты с акрил - и метилакриламидами в водно-щелочном растворе в присутствии четвертичных аммониевых солей}

Исследована кинетика образования карбамоильных производных при конденсации ацетоуксусного эфира (АУЭ) с акриламидом (АА) и $\alpha$-метилакриламидом (МАА) в водно-щелочном растворе в присутствии четвертичных аммониевых солей (ЧАС): тетраметиламмоний хлорид (ТМАХ), триэтилбензиламмоний хлорид (ТЭБАХ), триметилбутиламмоний хлорид (ТМБАХ), триметилгептиламмоний хлорид (ТМГАХ), триметилцетиламмоний хлорид (ТМЦАХ). Взаимодействие АУЭ с АА и МАА осуществлено при комнатной температуре $\left(20^{\circ} \mathrm{C}\right)$.

Данные табл. 6.17 показывают, что скорость реакции возрастает с увеличением поверхностной активности. Среди всех исследованных катионных ПАВ наибольшее ускоряющее действие оказывает ТМЦАХ, обладающий наибольшей поверхностной активностью.

Конденсация по Михаэлю происходит по механизму присоединения 1,4- с последующей перегруппировкой.

\section{$\mathrm{CH}_{3} \mathrm{COCH}_{2} \mathrm{COOC}_{2} \mathrm{H}_{5}+\mathrm{CH}_{2}=\mathrm{CH}-\mathrm{CONH}_{2} \rightarrow$ $\mathrm{CH}_{3} \mathrm{COCH}_{2}\left(\mathrm{COOC}_{2} \mathrm{H}_{5}\right)-\mathrm{CH}_{2}-\mathrm{CH}-\mathrm{CONH}_{2}$}

Активность $\mathrm{C}=\mathrm{C}$ связи молекулы акцептора тем выше, чем больше положительный заряд на $\beta$-углеродном атоме - $\mathrm{q}_{\beta \mathrm{C}}$, и отрицательный заряд на кислороде карбонильной группы - q0. C использованием пакета расчетных программ Hyper Chem по квантовохимическому полуэмперическому методу РМ-3 нами были проведены расчеты величины зарядов на $\beta C$-углеродном атоме и карбонильном кислороде молекул акцепторов (табл. 6.18). В таблице приведены также параметры Алфрея и Прайса: Q и е [398] 
Таблий 6.17.

Выходы и эффективные константы скоростей реакиий АА и МАА с АУЭ в присутствии ЧАС.

\begin{tabular}{|c|c|c|c|c|}
\hline \multirow{2}{*}{ ЧАС } & \multicolumn{2}{|c|}{ АА+АУЭ } & \multicolumn{2}{c|}{ МАА+АУЭ } \\
\cline { 2 - 5 } & $\begin{array}{c}\text { Степень } \\
\text { конверсии } \\
\text { за 2 часа, \% }\end{array}$ & $\begin{array}{c}10^{5} \mathrm{k}_{\text {эф }} \\
\text { моль }^{-1} \mathrm{c}^{-1}\end{array}$ & $\begin{array}{c}\text { Степень } \\
\text { конверсии } \\
\text { за 2 часа, \% }\end{array}$ & $\begin{array}{c}10^{5} \mathrm{k}_{\text {эф }} \\
\text { м }^{-1} \mathrm{c}^{-1}\end{array}$ \\
\hline - & 3.75 & 1.6 & 2 & 0.9 \\
\hline ТМАХ & 75 & 10.2 & 40 & 5.5 \\
\hline ТМБАХ & 80 & 11.5 & 45 & 6.3 \\
\hline ТМГАХ & 80 & 14 & 50 & 7.5 \\
\hline ТЭБАХ & 85 & 15.5 & 55 & 7.9 \\
\hline ТМЦАХ & 95 & 19 & 71 & 9.3 \\
\hline
\end{tabular}

Параметры Q и е, характеризующие стеричность двойной связи и заряд на $\beta$-углеродном атоме, были соответственно использованы для выражения активности акцепторов в реакции Михаэля [390]. В работе показано, что чем меньше Q и больше е, тем активнее акцептор по отношению к нуклеофилу. Полученные нами результаты по присоединению этилового эфира ацетоуксусной кислоты к соединениям подтверждают данное заключение.

Таблица 6.18.

Значения параметров Алфрея и Прайса: $Q$ и е; суммарного заряда на $\beta$-углеродном атоме $\left(q_{\beta C}\right)$ и заряда кислорода карбонильной группь $\left(q_{0}\right)$ для АА и МАA.

\begin{tabular}{|c|c|c|c|c|}
\hline Акцептр & $\mathrm{Q}$ & $\mathrm{e}$ & $\mathrm{q}_{\beta \mathrm{C}}$ & $\mathrm{q}_{0}$ \\
\hline AА & 1.18 & 1.3 & 0.059 & -0.017 \\
\hline MАA & 1.46 & 1.24 & 0.039 & -0.01 \\
\hline
\end{tabular}

Установлено, что выходы продуктов конденсации: этил-2ацетил-4-карбамоилбутаноата и этил-2-ацетил-4-карбамоилпентаноата, повышаются при увеличении поверхностной активности ЧАС. Установлено также, что метилакриламид входит в конденсацию труднее акриламида. 


\subsection{2. Окислительные и фотохимические реакции при деградации нефти в гидросфере}

Деградация нефти и нефтепродуктов осуществляется также путем химического окисления, и скорость этого процесса зависит от условий среды. Процессы окисления одних структур ингибируются другими, трансформация отдельных соединений идет по пути образования форм, в дальнейшем плохо окисляемых. Так, некоторая часть нефтяных углеводородов может разлагаться в процессе автокаталитического окисления по свободнорадикальной цепной реакции, завершающейся образованием гидроперекисей, а продукты разложения последних служат инициаторами дальнейшего окисления углеводородов. Процесс окисления нефти стимулируется металлосодержащими соединениями нефтей и инициируется действием солнечной радиации. Так, в ясную погоду может окислиться до 2 т/км² нефти за сутки. Окисление нефти в водных геосистемах ингибируется белками, фенолами, серосодержащими соединениями и аминами.

Фотохимические превращения загрязняющих веществ осуществляются в природной среде под действием ультрафиолетовой составляющей $(\lambda=310$ нм) при участии свободных радикалов - соединений, имеющих неспаренный электрон, находящихся в возбужденном состоянии. Свободно-радикальный механизм трансформации загрязняющих соединений в водной среде наиболее характерный механизм самоочищения в водоемах в результате фотохимических и биохимических реакций.

Ниже приведены работы по изучению в рамках модели «нефть-вода» ингибирующей способности ряда аминов: N-этил морфолин (ЭМ), амид-2-(N-морфолил)-пропионовой кислоты (АM), амид-1метил-2-(N-морфолил)-пропионовой кислоты (MM) и нитрил-2-(N-морфолил)-пропионовой кислоты (НM) при окислении кумола в хлорбензоле, инициированной азоизобутиронитрилом (АИБН) [204,401-404] и к НО· [204,405-408]. 


\subsubsection{1. Окисление кумола в присутствии аминов в модельной системе «нефть - вода»}

Следующая кинетическая схема достаточно хорошо описывает общий механизм ингибирования, инициированный АИБН окисления кумола (RH) вообще, и с аминами, в частности [405].

$$
\begin{aligned}
& \left(\mathrm{AИБН)} \stackrel{\mathrm{O}_{2}}{\longrightarrow} \mathrm{rO}_{2} \stackrel{\mathrm{RH}, \mathrm{O}_{2}}{\longrightarrow} \mathrm{RO}_{2},\right. \\
& \mathrm{k}_{2} \mathrm{RO}_{2}+\mathrm{RH} \rightarrow \mathrm{R}+\mathrm{ROOH}, \\
& \mathrm{k}_{6} \mathrm{RO}_{2}+\mathrm{RO}_{2} \rightarrow \text { молекулярные продукты }+\mathrm{O}_{2}, \\
& \mathrm{k}_{7} \mathrm{RO}_{2}+\mathrm{InH} \rightarrow \mathrm{In}+\mathrm{ROOH}, \\
& \mathrm{k}_{8} \mathrm{RO}_{2}+\mathrm{InH} \rightarrow \text { молекулярные продукты, }
\end{aligned}
$$

где в частном случае $\mathrm{InH}=$ Амин.

Анализ схемы при условии I >>1 приводит к уравнению:

$$
\begin{gathered}
\frac{W_{0}}{W}-\frac{W}{W_{0}}=2 \frac{K_{7}}{\left(W i K_{6}\right)^{1 / 2}} \operatorname{In} H, \\
\text { где } W_{0}=\frac{K_{2}}{K_{6}{ }^{1 / 2}} W i^{1 / 2} R H,
\end{gathered}
$$

где $\mathrm{W}_{0}$-скорость неингибированного окисления кумола, $\mathrm{a} \mathrm{W}-$ скорость в присутствии амина, обе определены по поглощению кислорода. Ранние работы $[401,410]$ по изучению ингибирующей способности аминов и аминоспиртов в радикально - цепных реакциях окисления углеводородов показывают, что последние являются неплохими ингибиторами (антиоксидантами). Значения $\mathrm{k}_{7}$ для аминов рассчитаны, приняв: $\mathrm{k}_{6}=4,1 \cdot 10^{4} \mathrm{M}^{-1} \mathrm{c}^{-1}[405]$ и $\mathrm{k}_{\text {расг } \cdot \text { Аиьн }}$ $=1,53.10^{-4} \mathrm{c}^{-1}$ (см.табл.6.19). 
Таблийа 6.19. Значения констант скорости ингибирования аутоокисления кумола $\left(k_{7}\right)$ при $T=353 K$ и $q_{N}, q_{a C}$ и $q_{a H}$ аминов.

\begin{tabular}{|l|l|l|l|l|}
\hline Амин & $\mathrm{k}_{7} \mathrm{M}^{-1} \mathrm{c}^{-1}$ & $\mathrm{q}_{\mathrm{N}}$ & $\mathrm{q}_{\alpha \mathrm{C}}$ & $\mathrm{q}_{\alpha \mathrm{H}}$ \\
\hline ЭM & 75 & -0.08 & -0.286 & 0.332 \\
\hline АМ & 87 & -0.071 & -0.310 & 0.368 \\
\hline MМ & 112 & -0.071 & -0.314 & 0.357 \\
\hline HМ & 175 & -0.069 & -0.311 & 0.360 \\
\hline
\end{tabular}

Из таблицы 6.19 следует, что амины располагаются в ряд:

$$
\mathrm{HM}>\mathrm{MM}>\mathrm{AM}>\mathrm{MM} \text {. }
$$

Общеизвестно, что взаимодействие аминов с акцепторами электронов вообще и с радикалами, в частности, начинается через стадию переноса электрона от амина к акцептору, с образованием ион-радикальной пары.

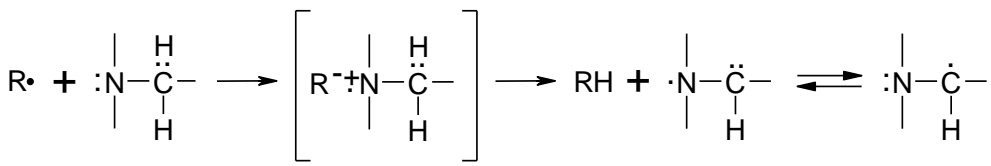

(где $\mathrm{R}^{*}=\mathrm{RNO}, \mathrm{RO}, \mathrm{RO}_{2}, \mathrm{HO} \cdot \mathrm{CH}_{3}, \mathrm{H}^{\circ}$ и т.д).

Из схемы (1.4) следует также важность величин $\mathrm{q}_{\alpha \mathrm{C}}$ и $\mathrm{q}_{\alpha \mathrm{H}}$ в молекуле амина. Учитывая это обстоятельство, нами впервые предлагается многопараметровое корреляционное уравнение, связывающее $\mathrm{k}_{7} \mathrm{c} \mathrm{q}_{\mathrm{N}}, \mathrm{q}_{\alpha \mathrm{C}}$ и $\mathrm{q}_{\alpha \mathrm{H}}$ :

$$
\operatorname{lgk} k_{7}=a_{0}+a_{1} q_{N}+a_{2} q_{\alpha C}+a_{3} q_{\alpha H}
$$

Для аминов получается:

$$
\operatorname{Lgk}_{7}=20,1135+108,316 q_{N}+18,287 q_{\alpha C}-13,082 q_{\alpha H}
$$

Это уравнение показывает, что с понижением $\mathrm{q}_{\mathrm{N}}, \mathrm{k}_{7}$ увеличивается. Следует отметить, что понижение $\mathrm{q}_{\alpha \mathrm{C}}$, т.е. увеличение $\mathrm{q}_{\alpha \mathrm{H}}$ 
благоприятно влияет на $\mathrm{k}_{7}$. Это заключение подтверждает правдоподобность представления о механизме реакций: радикал+амин.

\subsubsection{2. Реакция ОН радикалов с метаболидами конденсационной деградации нефти (аминами) в модельной системе «нефть- вода»}

В экологии в настоящее время все большее значение приобретают исследования, раскрывающие механизмы круговорота веществ и трансформации энергии в экосистемах, особенно в гидроэкосистемах, где активно участвуют различные органические вещества - вторичные метаболиты функционирования организмов, популяций и сообществ. Катастрофически возросло антропогенное воздействие на биосферу, одной из опасных форм которого является химическое загрязнение, что порождает нарушение экологического баланса, имеет отрицательное влияние на ход естественных физико-химических и биологических процессов в биогеоценозах.

Большой интерес представляют процессы радикального самоочищения в природных водных бассейнах под действием свободных радикалов, образующихся в природной воде В связи с этим в последнее время остро встают вопросы о механизме и количественной оценке способности водной среды к радикальному самоочищению в отношении различных конкретных загрязняющих веществ.

Роль свободных НО радикалов в реакциях автоокисления органических соединений общеизвестно. НО радикалы - наиболее сильные окислители, имеющиеся в водной среде. Они реагируют с большей частью органических веществ, со скоростью, чья константа близка диффузионной границе $\left(10^{9}-10^{10}\right.$ л.моль ${ }^{-1}$. сек $\left.^{-1}\right)$.

В основе определения реакционноспособности ОН-радикалов с различными аминами также лежит метод конкурирующих 
реакций аминов (Ам) и красителя паранитрозодиметиланилина (ПНДМА) в захвате НО радикалов.

$$
\begin{aligned}
& \frac{W_{1}-W_{2}}{W_{2}}=\frac{K_{O H+P}[O H][A м]}{K_{1}[O H][\Pi Н Д M A]} \\
& K_{O H+P}[A м]=K_{1}[\Pi Н Д M A]\left(\frac{W_{1}-W_{2}}{W_{2}}\right) \\
& K_{O H+P}=K_{1} \frac{[\Pi H Д M A]}{[A м]}\left(\frac{W_{1}}{W_{2}}-1\right)
\end{aligned}
$$

При $\mathrm{T}=298 \mathrm{~K}$ значение $\mathrm{k}_{1}=1,25.10^{10} \mathrm{M}^{-1} \mathrm{c}^{-1}, \mathrm{~W}_{1}$ и $\mathrm{W}_{2}$ - скорости обесцвечивания ПНДМА, определенные в отсутствие и в присутствии аминов, соответственно.

Для того чтобы убедиться в том, что для выражения реакционной способности аминов по отношению к НО. - радикалам потенциал ионизации (I) является подходящим параметром, в первую очередь нами по вышеописанному методу исследованы реакции НО радикалов с первичными, вторичными и третичными аминами, I которых известны.

Таблица 6.20.

Значения констант скорости реакции НО-радикалов с аминами при $T=298 K$.

\begin{tabular}{|c|c|c|c|c|c|c|}
\hline Амины & н-БА & ДЭА & ДПА & ДБА & ТЭА & ТПА \\
\hline $10^{-9} \cdot \mathrm{k}_{\text {НО+амин }}$, л.моль $^{-1} \cdot$ сек $^{-1}$ & 5,3 & 7,4 & 8,2 & 8,7 & 9,6 & 10 \\
\hline
\end{tabular}

Пользуясь данными табл.6.20, можно четко показать, что имеется хорошая корреляция между $\lg \mathrm{k}_{\mathrm{HO}+\text { амин }}$ и I соответствующего амина:

$$
\begin{gathered}
\operatorname{lgk}_{\mathrm{HO}+\text { амин }}=(11,544 \pm 0,074)-(0,209 \pm 0,009) \cdot I, R^{2}=0.9960, \\
S=0.0102, N=6
\end{gathered}
$$


Так как I удовлетворительно коррелирует с $\mathrm{q}_{\mathrm{N}-\mathrm{H}}$, когда первичные, вторичные и третичные амины рассматривались вместе.

Для использованных аминов получается:

$$
\begin{gathered}
\operatorname{lgk}_{\mathrm{HO}+\text { амин }}=(9.78 \pm 0.031)+(2,71 \pm 0,61) q_{\mathrm{N}-\mathrm{H}}, R^{2}=0.9300 \\
S=0,047, N=6
\end{gathered}
$$

Это говорит о том, что для характеристики реакционноспособности продуктов реакции $\mathrm{HC}+$ вторичный амин (образование третичных аминов) можно использовать заряд $\mathrm{q}_{\mathrm{N}}$. Константы скорости $\left(\mathrm{k}_{\mathrm{HO}}\right.$.) реакций продуктов реакций $\mathrm{HC}+$ вторичный амин с общей формулой с НО-радикалами приведены в табл. 6.21.

Таблица 6.21.

Значения констант скорости реакции НО-радикалов с аминами при $T=298 K$ и $q_{N}, q_{\alpha C}$ и $q_{\alpha H}$ аминов.

\begin{tabular}{|c|c|c|c|c|}
\hline Амин & $10^{-9} \cdot \mathrm{k}_{\mathrm{HO}+\text { амин }}, \mathrm{M}^{-1} \mathrm{c}^{-1}$ & $\mathrm{q}_{\mathrm{N}}$ & $\mathrm{q}_{\alpha \mathrm{C}}$ & $\mathrm{q}_{\alpha \mathrm{H}}$ \\
\hline ЭМ & 0.8 & -0.08 & -0.286 & 0.332 \\
\hline $\mathrm{AM}$ & 1.2 & -0.071 & -0.310 & 0.368 \\
\hline $\mathrm{MM}$ & 3.0 & -0.071 & -0.314 & 0.357 \\
\hline $\mathrm{HM}$ & 5.5 & -0.069 & -0.311 & 0.360 \\
\hline
\end{tabular}

Как видно, для реакций продуктов реакции конденсации Михаэля с НО -радикалом получается аналогичная картина, что и с $\mathrm{ROO}$ - радикалом, т.е. с уменьшением $\mathrm{q}_{\mathrm{N}}$, увеличивается $\mathrm{k}_{\mathrm{HO}+\text { Ам}}$. Получаем:

$$
\operatorname{lgk}_{\mathrm{HO}+\text { амин }}=72,137+352,76 q_{\mathrm{N}}+103,52 q_{\alpha \mathrm{C}}-16,26 q_{\alpha \mathrm{H}}
$$

Как видно, с понижением $\mathrm{q}_{\mathrm{N}}, \mathrm{k}_{\mathrm{HO}+\text { амин }}$ увеличивается. Следует отметить, что понижение $\mathrm{q}_{\alpha \mathrm{c}}$, т. е. увеличение $\mathrm{q}_{\alpha \mathrm{H}}$ благоприятно влияет на $\mathrm{k}_{\mathrm{HO}+\text { амин. }}$ Это заключение еще раз подтверждает правдоподобность представления о механизме реакции $\mathrm{HO}+$ амин.

Эффективность радикальной трансформации того или иного «загрязняющего» вещества под воздействием НО-радикалов определяется стационарной концентрацией НО-радикалов и их 
реакционноспособностью в отношении данного конкретного загрязнителя.

\section{6. О некоторых закономерностях загрязнения нефтепродуктами на примере реки Раздан и озера Севан}

Река Раздан берет свое начало из озера Севан и впадает в реку Аракс, которая является пограничной, и поэтому актуально изучение загрязнения воды нефтепродуктами. Цель изучения показать корреляцию содержания нефтепродуктов с водными и химическими показателями озера Севан и реки Раздан с целью выяснения естественного или техногенного характера нефтепродуктов [411].

Для анализа мы использовали мониторинговые 25 гидрохимические показатели озера Севан и реки Раздан, полученные в 2003-2005 гг. Разработка этих показателей с использованием математических методов позволяет сформировать мнение об их взаимосвязи.

Расчеты проводились с помощью компьютерной программы Origin-6. Проведен анализ линейной зависимости [НП] $=\mathrm{a}+\mathrm{b}$ [Показатель] в зависимости от загрязнения воды нефтепродуктами. Оказалось, что во все указанные сезоны и во всех исследованных точках наблюдения загрязнение нефтепродуктами превышало ПДК (0,05 мг / л), составляя 0,08-0,24 мг / л. Количество смол в реке Раздан составляло 0,03-0,12 мг/л, а в озере Севан 0-0,03 мг / л.

Высокое содержание нефтепродуктов и низкое количество смол и асфальтенов в озере Севан указывает на то, что для пресноводного озера Севан с трофической биологической активностью создается высокий фон нефтепродуктов. Вдоль реки Раздан, от озера Севан до устья, нет зонирования нефтепродуктов, что связано с тем, что река загрязнена по всей ее длине и в основном обусловлена антропогенным фактором. 
Основными источниками загрязнения нефтепродуктами являются моторные лодки, коммунальные службы в прибрежных городах и деревнях, прилегающие заправочные станции, автомойки, нефтяные склады и транспортные средства. Исследования показали, что нет линейной зависимости (коэффициент корреляции: $\left.\mathrm{R}^{2}<0,1\right)$ от количества нефтепродуктов и БПК ната, сульфата, нитрата, ионов $\mathrm{Ca}, \mathrm{Mg}, \mathrm{Na}, \mathrm{K}, \mathrm{Cu}, \mathrm{Cr}, \mathrm{Cr}, \mathrm{V}, \mathrm{Zn}$, $\mathrm{Mn}$, минерализации и $\mathrm{pH}$. Анализ показывает, что количество нефтепродуктов уменьшается из-за повышения температуры воды в реке Раздан.

$$
[\mathrm{H \Pi}]=0,187-0005 \cdot\left[\mathbf{t}^{0}\right], \mathbf{R}^{2}=0,3500, N=20
$$

Те же закономерности наблюдаются и в озере Севан. Эту закономерность можно ожидать, поскольку солнечное ультрафиолетовое излучение ускоряет расщепление нефтяных компонентов и испарение более летучих компонентов.

Количество нефтепродуктов имеет линейную зависимость с содержанием общего фосфора, нитрита и хлорид-ионов.

$$
\begin{gathered}
{[\mathrm{HI}]=0,125+0,06 \cdot\left[\mathrm{NO}_{2}^{-}\right], \mathbf{R}^{2}=0,2510, N=20} \\
{[\mathrm{HI}]=0,131+0,013 \cdot[\mathrm{P}], \mathbf{R}^{2}=\mathbf{0 , 3 0 0 5}, \mathbf{N}=\mathbf{2 0}} \\
{[\mathrm{HI}]=0,156+0,001 \cdot\left[\mathrm{Cl}^{-}\right], \mathbf{R}^{2}=\mathbf{0 , 4 2 0 0}, \mathrm{N}=\mathbf{2 0}}
\end{gathered}
$$

Это связано с загрязнением коммунально-бытовыми стоками. Увеличение количества растворенного кислорода, ионов железа, а также смол и асфальтенов приводит к уменьшению количества нефтепродуктов.

$$
\begin{aligned}
& {[\mathrm{H \Pi}]=0,167-0,002 \cdot\left[\mathrm{O}_{2}\right], \mathrm{R}^{2}=\mathbf{0 , 2 3 0 0}, \mathrm{N}=\mathbf{2 0}} \\
& {[\mathrm{HI}]=0,162-0,011 \cdot\left[\mathrm{Fe}^{+3}\right], \mathbf{R}^{2}=0,2410, \mathrm{~N}=20} \\
& {[\mathrm{HII}]=0,158-0,033 \cdot[\text { Асф. }], R^{2}=0,2610, N=20}
\end{aligned}
$$

Этот факт говорит об окислении и конденсации нефтепродуктов в реке Раздан, то есть о процессе самоочищения. Из упомянутых обсуждений можно сделать вывод, что в период 2003-2005гг. загрязнение нефтепродуктами в озере Севан и реке 
Раздан провышало ПДК (0,05мг/л.), составляя 0,08 - 0,24мг/л. Большое количество нефтепродуктов в озере Севан исходит из высокого фона образования биогенных углеводородов. По длине реки Раздан, начиная с Севана до устья реки зональность количества нефтепродуктов не наблюдается. Причиной тому является то, что река по всей длине загрязняется и это имеет антропогенный характер. В реке Раздан происходит процесс самоочищения от нефтепродуктов. 


\section{Активные участники форума «Глубинная нефть» и конференций Кудрявцевские Чтения, чьи работы были обсуждены в книге}

Тимурзиев Ахмет Иссакович, Заместитель Главного геофизика ОАО «Центральная геофизическая экспедиция» (г. Москва), доктор геолого-минералогических наук, академик РАЕН. Председатель Оргкомитета Кудрявцевских Чтений, учредитель и Главный редактор журнала «Глубинная нефть».

Тимофеев Дмитрий Николаевич, директор фирмы «Космические технологии».

Карпов Валерий Александрович, канд. геол-мин. наук, член редакционного совета журнала «Недропользование. XXI век».

Зинатов Хайдар Галимович, ведущий геолог ООО НПП «Геотраверс», кандидат г.-м. наук, г. Казань, Республика Татарстан, РФ.

Андреев Николай Михайлович, шеф компании «Геолисс», который объединяет геофизиков, гидрогеологов, геологов, экологов Багдасарова Марина Вартановна, работает в ИПНГ РАН в Лаборатории разномасштабных геодинамических и физикохимических процессов в геологических средах, где продолжает обобщение материалов, полученных на геодинамических полигонах.

Шевченко Николай Борисович, геолог І-й категории, Центр геолого-тематических исследований ПАТ «Укрнафта», Киев.

Арутюнян Альберт Вирабович, кандидат технических наук, доцент Ереванского политехнического университета.

Шестопалов Анатолий Васильевич, научный сотрудник ИПКОН PAH.

Устьяниев Валерий Александрович, пенсионер.

Ерилин Сергей Александрович, директор ООО «Подземная механика». 


\section{ЛИТЕРАТУРА}

1. Леворсен А. Геология нефти и газа. М .: Мир, 1970. 640 с.

2. Симонян Г.С. Элементный и химический состав нефти. Техника и технологии XXI века: Монография. Книга 4 / под общ. ред. И. Б. Красиной / Ставрополь: Логос, 2015. с.170-189.

3. Симонян Г.С. Эндогенное образование нафтидов в свете абиогенной теории образования нефти. //Научное обозрение. Технические науки, 2016, №4, с.77-101.

4. Сыркин А.М., Мовсумзаде Э.М. Основы химии нефти и газа. Уфа: УГНТУ, 2002.-109 с.

5. Магеррамов А.М., Ахмедова Р.А., Ахмедова Н.Ф. Нефтехимия и нефтепереработка. Учебник для высших учебных заведений. Баку: Бакы Университети, 2009. 660 с.

6. Сафиева Р.3. Химия нефти и газа. Нефтяные дисперсные системы: состав и свойства (часть 1). Учебное пособие. М.: РГУ нефти и газа им. И.М.Губкина. 2004.112с.

7. Губкин И.М. Учение о нефти. М: Наука, 1975. 387 с.

8. Вернадский В.И. О научном мировоззрении // На переломе. Философские дискуссии 20 -х годов. Философия и мировоззрение. М., 1990. C.180-203.

9. Кропоткин П.Н. Проблемы происхождения нефти. //Советская геология, 1955, №47, с. 104-125.

10. Кудрявцев Н.А. Генезис нефти и газа. Л.: Недра, 1973. 216 с.

11. Чекалюк Э.Б. Нефть верхней мантии. Киев: Науково думка, 1967. 256c.

12. Тимурзиев А.И. «Октябрьские тезисы» или о начале второго этапа подготовки «Октябрьской революции» по смене парадигмы нефтегазовой геологии в России. Уральский геологический журнал, 2016 № 6 (114), c. 68-76.

13. Gold $\mathrm{T}$. The origin of natural gas and petroleum, and the prognosis for future supplies.// Ann. Rev. Energy, 1985, v.10, p. 53-77.

14. Бондаренко В.И., Варламов Г.Б., Вольчин И.А. и др. Энергетика: история, настоящее и будущее. Т.1. От огня и воды к электричеству. -К.: 2005. -304 с.

15. Менделеев Д.И. Сочинения. Л.-М.: АН СССР, 1949, т.10,с.302310.

16. Соколов В.Д. Космическое происхождение битумов.//Бюллетень МОИП, VIII, нов. сер., 1889. 
17. Каграманов Ю.Р., Егикян А. Г. К вопросу о генезисе нефти // Геология нефти и газа, 2000, №5, с.26-29.

18. Воробьев А.А. Физические условия залегания и свойства глубинного вещества. (Высокие электрические поля в земных недрах). Томск: ТГУ, 1975.

19. Зубков В.С. К вопросу о составе и формах нахождения флюида системы C-H-N-O-S в РТ-условиях верхней мантии //Геохимия, 2001, № 2, c. 131-145.

20. Зубков В.С., Лузин В.Ф., Андреев В.Ф. Нефть и газ в современном мире. Иркутск: ИГК, 2003, с.23-45.

21. Зубков В.С., Степанов А.Н., Карнов И.К., Бичкинский В.А. Термодинамическая модель системы C-Н в условиях высоких температур и давлений.//Геохимия, 1998, № 1, с. 95-101.

22. Зубков В.С. О двух ветвях мантийного флюида. Геология и металлогения докембрия юга Сибири. Иркутск, 1999, с. 39-43.

23. Маракушев А.А., Маракушев С.А. Образование нефтяных и газовых месторождений. //Литология и полезные ископаемые, 2008, №5, c. $505-521$.

24. Маракушев А.А., Панеях Н.А., Маракушев С.А. Образование сульфидных руд и углеводородов в срединно-океанических хребтах. //Электронный журнал "Глубинная нефть", 2014, т. 2, №5, с.689-698.

25. Сорохтин О.Г., Ушаков С.А. Развитие Земли. М.: МГУ, $2002.506 \mathrm{c}$.

26. Юркова Р.М. Мантийно-коровая серпентинизация ультрабазитов как источник углеводородных флюидов. //Фундаментальный базис новых технологий нефтяной и газовой промышленности. М.:ГЕОС, 2002, c. 98-107.

27. Арутюнян А.В. Земная кора Малого Кавказа, офиолиты, вулканизм, нефтегазоносность, сейсмичность./Вестник ОНЗ РАН, 2, NZ6006. doi:10.2205/2010NZ000024, 2010.

28. Алексеев В.А., Дюжева Т.И., Мельник Н.Н. Водородно-углеродная дегазация Земли и образование мелкодисперсного углерода при высоких давлениях и температурах. //Дегазация Земли: геотектоника, геодинамика, геоморфология, нефть, газ, углеводороды и жизнь. 10-22 октября 2010, Москва: ГЕОС, 2010, с. 21-22.

29. Кучеров В.Г., Бенделиани Н.А., Алексеев В.А., Кенней Д.Ф. Синтез углеводородов из минералов при давлении до 5 ГПа.// Доклады РАН, 2002, т.387, №6, с. 789-792.

30. Кучин Е.С. Об основных вопросах эндогенного рудообразования. // Отечественная геология, 2001, №1, с. 20-30. 
31. Тимофеев Д.Н Структура Земли и генерация углеводородов в свете законов ядерной физики, химии и химической термодинамики. Первые Кудрявцевские Чтения. Центральная Геофизическая Экспедиция Москва 2012г. http://www.youtube.com/watch?v=hSkgMjXdNdg\&feature $=$ plcp

32. Тимофеев Д.Н. Модель ядра планеты Земля и процессы, происходящие в нём. Пузырёвские чтения-2009Г Сейсмические исследования земной коры. ИНГГ СО РАН Новосибирск, 2009, с.287-290.

33. Тимофеев Д.Н. Природа космических тел Солнечной системы. Красноярск: Город, 2018. 226 с.

34. Тимофеев Д.Н. Структура мантии Земли и синтез углеводородов в свете теории химических процессов.//лектронный журнал "Глубинная нефть", 2014, с. 2, №9, с.1455-1469.

35. Тимофеев Д.Н. Силановая нефть и глобальные процессы трансформации Земли.//Восьмые научные чтения Ю.П. Булашевича Геодинамика, глубинное строение, тепловое поле Земли, интерпретация геофизических полей. ИГ УрО РАН Екатеринбург, 2015, с.316-320.

36. Тимофеев Д.Н. Образование залежей углей как одна из ветвей преобразования глубинных углеводородов. Седьмые Кудрявцевские Чтения. Центральная Геофизическая Экспедиция Москва 2019. http://conference.deepoil.ru/images/stories/docs/7KR/theses/Timofeev_These s.pdf

37. Тимофеев Д.Н. Энергии тектонических процессов в свете законов ядерной физики, химии и химической термодинамики. Четвертая тектонофизическая конференция в ИФЗ РАН. 3.7октября, Москва 2016, т.2, с. 576-585. http://www.ifz.ru/fileadmin/user_upload/subdivisions/506/Konferencii/2016/Mat/V2/5/Timofeev.pdf

38. Лурье М.А., Шмидт Ф.К. Конденсационные превращения эндогенного метана под воздействием серы - возможный путь генезиса нефти.//Российский химический журнал, 2004, т. XLVIII, № 6, с. 135-147.

39. Лурье М.А., Шмидт Ф.К. О связи содержания серы и других характеристик нефти. Абиогенный вклад в нефтеобразование. // Химия и технология топлив и масел, 2007, № 4, с. 3-6.

40. Симонян Г.С. Роль никеля в генезисе нефти //Булатовские чтения: материалы IV Международной научно-практической конференции (31 марта 2020 г.): в 7 т.: сборник статей / Под общ. ред. д-ра техн. наук, проф. О.В. Савенок. - Краснодар : Издательский Дом - Юг.Т. 5: Прогно3, поиск и разведка месторождений нефти и газа. Нефтегазопромысловая геология. Разведочная и промысловая геофизика. 2020.с. 150-153. 
41. Симонян Г.С. Роль металлопорфиринов никеля и ванадия в абиогенном образовании нефти // Современные наукоемкие технологии, 2015, № 9, с. 82-85.

42. Симонян Г.С. Роль порфиринов в генезисе нефти. // Материалы международной научно-методической конференции: Интеграция науки и образования в вузах нефтегазового профиля.2014. Уфа: РИЦ УГНТУ, 2014, c. $147-150$.

43. Симонян Г.С. Эндогенное образование ванадиевых руд и нафтидов. // Международный журнал прикладных и фундаментальных исследованый, 2015, №5, ч. 2, с.273-276.

44. Симонян Г.С. Влияние азота на глубинный цикл углерода при генезисе нефти. //Международная конференция «Каталитические процессы нефтепереработки, нефтехимии и экологии» октябрь 2013, Ташкент, Республика Узбекистан: сборник тезисов докладов изд Институт катализа СО РАН, Новосибирск, Россия. -2013. -с.136.

45. Симонян Г.С., Пирумян Г.П. Роль азота в генезисе нефти. //Сборник научных трудов "Фундаментальные и прикладные проблемы науки".№6 VIII Международный симпозиум по фундаментальным и прикладным проблемам науки. М.: РАН, 2013, с.142-152.

46. Симонян Г.С., Пирумян Г.П. Роль азота в эндогенном образовании нефти. Современная наука: актуальные проблемы и перспективы развития: монография. книга 4 / под ред. проф. Н. А. Тарасенко/ Ставрополь: Логос, 2014, с.84-100.

47. Simonyan G.S. Evaluation of the influence of nitrogen on the stability of naptic systems with the help of geo-ecological evolving organized index // Oxidation Communications, 2019, v.42, №3, p.329-336. $506 \mathrm{c}$.

48. Сорохтин О.Г., Ушаков С.А. Развитие Земли. М.: МГУ, 2002.

49. Dillion T., Jeanzol R. High pressure temperature phase of iron nitride: Preliminary results.//Abstr. AGU Meet., San Francisco, Calif., Dec. 7-11, 1992. - Eos, 1992, v. 73, № 43, p.64.

50. Андриевский Р.А., Урбанович В.С., Кобелев Н.П., Торбов В.И. Высокотемпературная консолидация и физико-механические свойства нанокристаллического нитрида титана //Докл. РАН, 1997, т.356, №1, с. $39-41$.

51.Zhang J., Oganov A. R., LI X., NIU H. Pressure-stabilized Hafnium Nitrides and Their// Properties. Phys Rev, 2017. B 95, 020103(R) https://doi.org/10.1103/PhysRevB.95.020103.

52. Кадик А.А., Куровская Н.А., Игнатьев Ю.А., Кононкова Н.Н., Колташев В.В., Плотниченко В.Г. Влияние летучести кислорода на 
растворимость азота, углерода и водорода в расплавах $\mathrm{FeO}-\mathrm{Na}_{2} \mathrm{O}-\mathrm{SiO}_{2}-$ $\mathrm{Al}_{2} \mathrm{O}_{3}$, металической фазой железа при 1.5 ГПа и $1400^{\circ} \mathrm{C}$. //Геохимия, 2011, № 5, c.451-461.

53. Кадик А.А., Колташев В.В., Крюкова Е.Б., Плотниченко В.Г. Изучение форм растворения летучих соединений водорода, углерода, азота и кислорода в магматических расплавах ранней мантии земли методами ИК и КР спектроскопии. //Вестник ОНЗ РАН, 2011, №3. NZ6031, doi:10.2205/2011NZ000161.

54. Qian G.R., Niu H.,Hu C.H.,Oganov A.R., Zeng Q., Zhou H.Y. Diverse Chemistry of Stable Hydronitrogens, and Implications for Planetary and Materials// Sciences. Sci Rep 2016 №6, 25947. DOI: 10.1038/srep25947

55. Simonian G.S., Beylerian N.M. The solvent action on Michaelis reaction rate. A New Parameter concerning the solvent Polariti. //Oxidation Communication, 2003,v.26, №4,p.485-491.

56. Simonian G. The michael reaction in the model double-phase system «oil-water»// GISAP: Physics, Mathematics and Chemistry.2014. №4 -P. 37-39.

57. Simonian G.S.,Beyleryan N.M. Dependent of amines reactiviti on the charge nitrogen atom in the amine molecule. // Oxidation Communication, 2004,v.28 № 2. p.275-283.

58. Simonian G. S., Pirumyan G. P. Reactions of unsaturated surfactants with methylethanolamine in the model oil-water system //Russian Journal of General Chemistry.2014, v.84, № 13, p. 2552-2554.

59. Несмиянов А.Н., Несмиянов Н.А. Начала Органической химии. М.: Химия, 1970, т.2. 824c.

60. Краюшкин В.А. Абиогенно-мантийный генезис нефти. Киев: Наук. думка, 1984. 176 с.

61. Краюшкин В.А. Небиогенная природа гигантского газонефтенакопления на мировом континентальном склоне. //Геол. и полезн. ископ. Мирового океана,, 2013, № 4, с. 29-45.

62. Вдовиченко А.И., Ермаков П.П., Ермаков Н.П. Неисчерпаемый запас. Концепция интенсификации и оптимизации нефтегазодобычи с учетом восстановительных процессов.//Нефтяное обозрение «ТЕРМИНАЛ». 2016, № 26 (829), с. 4-7.

63. Вдовиченко А. И., Ермаков П.П., Ермаков Н.П. Формирование нового научного мировозрения на основе учения о неисчерпаемости и безопасности глубинных углеводных ресурсов // Форум гірників - 2019: матеріали міжнар. наук.-техн. конф., 26-27 верес. 2019 р. До 120-річчя заснування Університету. Дніпро: Журфонд, 2019, с. 201-206.

64.Гожик П.Ф., Лукин А.Е., Вдовиченко А.И, Петровский А.П., Коваль А.Н. Новая теория о возобновляемости, неисчерпаемости и эко- 
логичности глубинных нефтегазовых ресурсов //«Информационно-аналитический еженедельник «Зеркало недели. Украина», № 3, 26.01.2019.

65. Шевченко Н.Б, Фиалко А.И., Сухомлинов Ю.А., Довжок Т.Е. Кавитационно-флуктуационная гипотеза синтеза нефти и формирование её месторождений// Геолог Украины, 2003, №3-4, с.50-55.

66. Дроздовская А.А., Фиалко А.И., Шевченко Н.Б. О неорганическом происхождении высокомолекулярных углеводородов и элементного углерода в раннем докембрии // Материалы конференции "Геодинамика и нефтегазоносные системы Черноморско-Каспийского региона", Гурзуф, 17-21 сентября. Симферополь: Таврия-Плюс 2001, с. $56-57$.

67. Шевченко Н.Б., Фиалко А.И., Сухомлинов Ю.А. О предполагаемом парагенезисе нефти и алмазов в эксплозивных кимберлитовых трубках// Тезисы доклада на Международной конференции памяти академика П.Н.Кропоткина " Дегазация Земли: геодинамика, геофлюиды, нефть и газ". 20-24 мая 2002 года, Москва. М.: Геос, 2002. 400 с.

68. Зинатов Х.Г., Ефимов А.А. Выбор нефтеперспективных площадей в Республике Татарстан на основе неогеодинамических исследований и разработки моделей месторождений углеводородов с применением тектонофизического анализа. // Нефть. Газ. Новации. 2011, № 4, с. 53-67.

69. Тимурзиев А.И. Современное состояние теории происхождения и практики поисков нефти: тезисы к созданию научной теории прогнозирования и поисков глубинной нефти. //Электронный журнал "Глубинная нефть", 2013, т.1, №1, с.18-44.

70. Тимурзиев А.И. Мантийные очаги генерации углеводородов: геолого-физические признаки и прогнозно-поисковые критерии картирования; закономерности нефтегазоносности недр как отражение разгрузки в земной коре мантийных УВ-систем. //Электронный журнал "Глубинная нефть", 2013, т.1, №10, с.1498-1544.

71. Тимурзиев А.И. Развитие теории неорганического происхождения нефти в работе Кудрявцевских чтений, проводимых в рамках проекта «глубинная нефть»// VI-е Кудрявцевские Чтения - Всероссийская конференция по глубинному генезису нефти и газа. М: ГН, 2018, с. $4-13$.

72. Тимурзиев А.И. Современное состояние теории происхождения и практики поисков нефти: на пути к созданию научной теории прогнозирования и поисков глубинной нефти // Тектоника и стратиграфия, 2016, вып. 43, с. 102-132. 
73. Варламов А. И., Лоджевская М. И. Углеводородный потенциал глубокозалегающих отложений осадочного чехла нефтегазоносных бассейнов мира // Современное состояние теории происхождения, методов прогнозирования и технологий поисков глубинной нефти (1-е Кудрявцевские чтения): материалы Всерос. конф. М.: ЦГЭ, 2012. с. 1-3.

74. Gulf of Mexico Waits For A Turnaround // World Oil. 2002. March. URL: https://www.worldoil.com/magazine/2002/march-2002/features/gulfofmexico-waits-for-a-turnaround

75. Краюшкин В. А. Небиогенная природа гигантских газонефтенакоплений на континентальном склоне Мирового океана // Электронный журнал "Глубинная нефть", 2014, т.2, №5, с.739-751.

76. Иванов К. С. О возможной максимальной глубине нахождения месторождений нефти // Известия УГГУ, 2018, вып. 4(52), с. 41-49. DOI 10.21440/2307-2091-2018-4-41-49

77. Николаев А.Я. Биологическая химия. М.: МИА, 2001.496с.

78. Таубе П.Р., Баранова А.Г. Химия и микробиология воды. М.:Высш.шк.,1983.263c.

79. Эйгенсон А.С. О противостоянии двух концепций нефтегазообразования.//Химия и технология топлив и масел, 1998, №3, с. 3-5.

80. Симонян Г.С. Экологические проблемы получения металлов из нефти. //IV Международная конференция по химии и химической технологии: Сборник материалов.-Ер.: Институт общей и неорганической химии НАН РА, 2015, с.270-272.

81. Гилинская Л.Г. Спектры ЭПР комплексов V(IV) и структура нефтяных порфиринов. //Журн. структурной химии, 2008, т. 49, № 2, с. 259-268.

82. Насиров Р.Н., Солодовников С.П., Якуцени С.П. Сопоставление результатов определения ванадия в нефтях методами ЭПР и ФРРА. //Нефтяное хозяйство, 1992, №10, с.27-28.

83. Симонян Г.С. Перспективы получения металлов из нефти.// «Инновационные технологии и проекты в горно-металлургическом комплексе, их научное и кадровое сопровождение» Сборник трудов Международной научно-практической конференции. - Алматы: КазНТУ, 2014, с.446-449.

84. Те Л.А. Физико-химические исследования парамагнитных отложений Прикаспийской впадины:Автореф. дисс. канд. химич. наук. -Караганда, 2007.21c

85. Шило Н.А. Витватерсранд. Физика рудогенеза. //Известия секции наук о земле РАEH, 2008, вып.16, с. 3-12. 
86. Соколов Б.А. Новые идеи в геологии нефти и газа. М.: МГУ, $2001.480 \mathrm{c}$.

87. Озерова Н.А. Ртуть как индикатор участия мантийных флюидов в формировании ртутьсодержащих углеродородных местораждений. Современное состояние теории происхождения, методов прогнозирования и технологий поисков глубинной нефти.// 1-е Кудрявцевские Чтения. Материалы Всероссийской конференции по глубинному генезису нефти.- М.: ЦГЭ, 2012, с. 339.

88. Каграманов Ю.Р. К проблеме преспектив нефтегазоносности Арарат-Арагацской впадины. Ереван: Асогик, 2010.141с.

89. Гаврилов В.П. Возможные механизмы естественного восполнения запасов на нефтяных и газовых месторождениях.//Геология нефти и газа, 2008, №1, с.57-65.

90. Simonyan G.S. Abiogenous organic matter in the solar system// GISAP: Physics, Mathematics and Chemistry,2017, №8, p.8-14. DOI: http://dx.doi.org/10.18007/gisap:pmc.v0i8.1551.

91. Simonyan G.S. Organic components of oil in meteorites and comets // GISAP: Physics, Mathematics and Chemistry. 2017.- .№8 - P.19-24 DOI: http://dx.doi.org/10.18007/gisap:pmc.v0i8.1553

92. Simonyan G.S. Organic matter in the interstellar medium // GISAP: Physics, Mathematics and Chemistry, 2017, №8, p.32-37. DOI: http://dx.doi.org/10.18007/gisap:pmc.v0i8.1555.

93. Симонян Г.С. Абиогенное органическое вещество в солнечной системе Peer-reviewed materials digest (collective monograph) published following the results of the CXXIX International Research and Practice Conference and II stage of the Championship in Physics and Mathematics, Chemistry, Earth and Space Sciences (London, September 13 - September 19, 2016 International Academy of Science and Higher Education (London, UK)Published by IASHE London 2016, p.13-18.

94. Симонян Г.С. Органические составляющие нефти в метеоритах и кометах Peer-reviewed materials digest (collective monograph) published following the resultsof the CXXXVI International Research and Practice Conference and III stage of the Championship in Physics and Mathematics, Chemistry, Earth and Space Sciences(London, December 20 - December 26, 2016) 2016 International Academy of Science and Higher Education (London, UK)Published by IASHE London 2017, p.15-19.

95. Симонян Г.С. Органическое вещество в межзвездной среде. Peer-reviewed materials digest (collective monograph) published following the results of the CXXII International Research and Practice Conference and I stage of the Championship in Physics and Mathematics, Chemistry, Earth 
and Space Sciences (London, April 27 - May 6, 2016) //International Academy of Science and Higher Education;- London: IASHE, 2016. p14-17.

96. Сокальский И.А. Темная материя// Химия и жизнь, 2006, №11, c. $24-27$

97. Okabe N., Graham P. Smith G.P, Umetsu K.,Takada M.,Futamase T. LoCuSS: The mass density profile of massive galaxy clusters at $\mathrm{z}=0.2$ // Astrophysical Journal Letters,2013, v.769, №2, p. 35-40. DOI:10.1088/20418205/769/2/L35

98. Спитцер Л. Пространство между звездами /Пер. с англ. к.физ.мат. наук Б.М.Шустова, под ред. д-ра физ.-мат. наук В.И.Слыша. М.: Мир, 1986.182 с.

99. Кравчук П. А. Рекорды природы. Л.: Эрудит, 1993. 216 с.

100. Вдовыкин Г. П. Углеродистое вещество метеоритов. (Органические соединения, алмазы, графит). М.: Наука, 1967. 271с.

101. Nooner D. W., Oro J. Organic compounds in meteorites. I: Aliphatic hydrocarbons. //Geochim. Cosmochim. Acta, 1967, v. 31, p.13591394.

102. Belsky T., Kaplan I. R. Light hydrocarbon gases. $C^{13}$, and origin of organic matter in carbonaceous chondrites.// Gcocb. Cosmoch. Acta, 1970, v.34, № 3, p.257-278.

103. Levy R. L., Wolf C. J.,Drayson M. A., Gilbert J., Gelpi E., I'pdcgrove W. S., Zlatkis L., Ого J. Organic analisis of the Pueblito di Allende meteorite.//Nature,1970, v.227, №5254, p.148-150. doi:10.1038/ $227148 \mathrm{a} 0$

104. Войткевич Г.В. Возникновение и развитие жизни на Земле.М.: Наука, 1988.144c.

105. Schmitt-Kopplin P., Gabelica Z., Gougeon R.D., Fekete A., Kanawati B., Harir M., Gebefuegi I., Eckel G., Hertkorn N. High molecular diversity of extraterrestrial organic matter in Murchison meteorite revealed 40 years after its fall // Proceedings of the National Academy of Sciences U.S.A.,2010, v.107 (7), p.2763-2768. doi: 10.1073/pnas.0912157107.

106. Галимов Э.М., Колотов В. П., Назаров М. А., Костицын Ю. А., Кубракова И. В., Кононкова Н. Н., Рощина И. А., Алексеев В. А., Кашкаров Л. Л., Бадюков Д. Д., Севастьянов В. С. Результаты вещественного анализа метеорита челябинск //Геохимия, 2013, т.51, №7, c.580-598. DOI: 10.7868/S0016752513070108.

107. Романовская Г.И. Определение органических соединений в некоторых образцах челябинского метеорита методом синхронной спектрофлуориметрии //Геохимия, 2013, т.51, №7, с.650-653. DOI: 10.7868/S0016752513070145. 
108. Алексеев В.А, Беркут А.И., Мельник Н.Н.. Исследование метеоритов методом КРС. Челябинский метеорит и Тунгусский феномен // В кн. Комбинационное рассеяне - 85 лет исследований. Ред. А. Н. Втюрин. -Красноярск: ИФ СО РАН, 2013, с. 162-171.

109. Mousis O., Lunine J. I., Luspay-Kuti A., Guillot T., Marty B., AliDib M., Wurz P., Altwegg K., Bieler A., Hässig M., Rubin M., Vernazza P., Waite J. H. A Protosolar Nebula Origin for the Ices Agglomerated by Comet 67P/Churyumov-Gerasimenko // The Astrophysical Journal Letters, 2016, v. 819, №2, p.33. http://dx.doi.org/10.3847/2041-8205/819/2/L33

110. Bierson C. J, Phillips R. J., Smith I. B., Wood S. E., Putzig N. E., Nunes D., Byrne S. Stratigraphy and evolution of the buried $\mathrm{CO}_{2}$ deposit in the Martian south polar cap //Geophysical Research Letters, 2016, v.43, issue 9, p.4172-4179. DOI:1-0.1002/2016GL068457

111. Webster Ch.R., Mahaffy P.R., Atreya S.K., Flesch G.J., Mischna M.A. et.al. Mars methane detection and variability at Gale crater. // Science, 2015, v. 347, issue 6220, p. 415-417. DOI: 10.1126/science.1261713.

112. Дядин Ю.А., Гущин А.Л. Газовые Гидраты //Соросовский Образовательный Журнал, 1998, № 3, с.55-64.

113. Atreya S. K., Mahaffy P. R., Niemann H. B., Wong M. H., Owen T. C. Composition and origin of the atmosphere of Jupiter - an update, and implications for the extrasolar giant planets.//Planetary and Space Science, 2003, v.51, issue 2, p.105-112.

114. Elkins-Tanton L. T. Uranus, Neptune, Pluto, and the Outer Solar System. New York: Chelsea House, 2006, p. 13. (The Solar System). ISBN 0-8160-5197-6.

115. Stern S. A., Bagenal F., Ennico K. et al. (2015). The Pluto system: Initial results from its exploration by New Horizons.// Science, 2015, v.350 (6258). DOI:10.1126/science.aad181.

116. ESA Cassini - Huygens First Science Results. URL: http://huygens.esa.int/sciencee/ www/object/printfriendly.cfm?fobjectid=36370.

117. Cornet T., Cordier D., Le Bahers T., Bourgeois O., Fleurant C., Le Mouélic S., Altobelli N. Dissolution on Titan and on Earth: Toward the age of Titan's karstic landscapes// Journal of Geophysical Research, 2015, v.120 (6), p.1044-1074.

118. Cordier D., Mousis O., Lunine J.-I., Lavvas P. Vuitton V. An estimate of the chemical composition of Titan's lakes //Astrophys, 2009, v.707,№2, p.128-131, doi:10.1088/0004-637X/707/2/L128. 
119. Алексеева В.А., Алексеева Н.Г. Криогенные газогидратные вулканы на титане.// Тез.докл. Всероссийской конференции по глубинной нефти 4-ое КЧ, 2015, с.1-5.

120. Mitria G., Showman A. P., Lunine J. I., Lorenz R. D. Hydrocarbon lakes on Titan.//Icarus, 2007, v.186, p. 385-394. DOI:10.1016/j.icarus.2006.09.004.

121. Niemann H. B., Atreya S. K., Bauer S. J., Carignan G. R., Demick J. E., Frost R. L. The abundances of constituents of Titan's atmosphere from the GCMS instrument on the Huygens probe.// Nature, 2005, v.438(7069).p.779-784.DOI:10.1038/nature04122.

122. Anderson C. M., Samuelson R. E., Yung Y. L., McLain J. L. Solid-state photochemistry as a formation mechanism for Titan's stratospheric $\mathrm{C}_{4} \mathrm{~N}_{2}$ ice clouds // Geophysical Research Letters, 2016, v.43, issue 9, p.3088-3094. DOI: 10.1002/2016GL067795

123. Choblet G.,Tobie G., Sotin Ch., Běhounková M.,Čadek O., Postberg F., Souček O. Powering prolonged hydrothermal activity inside Enceladus//Nature Astronomy (2017) doi:10.1038/s41550-017-0289-8

124. Vidal-Madjar A., Desert J.-M., Lecavelier des Etangs A., Hebrard G., Ballester G.E., Ehrenreich D., Ferlet R., McConnell J.C., Mayor M., Parkinson C.D. Detection of oxygen and carbon in the hydrodynamically escaping atmosphere of the extrasolar planet HD209458b// Astrophys, 2004, v.604, p.69.

125. Каноза А. Кинетика газофазных реакций при сверхнизких температурах: современные достижения в химии углерода с использованием метода CRESU.//Успехи химии, 2007, т.76, вып.12, с.11711184.

126. Comito C., Schilke P. Increased complexity in interstellar chemistry: detection and chemical modeling of ethyl formate and $n$-propyl cyanide in Sagittarius B2(N). //Astronomy \& Astrophysics, 2009, v.499, №1, p.215-232. DOI: 10.1051/0004-6361/200811550.

127. Belloche A., Garrod R. T., Müller H. S. P., Menten K. M. Detection of a branched alkyl molecule in the interstellar medium: iso-propyl cyanide.// Science, 2014, v.345, p.1584-1587.

128. Iglesias-Groth S., Manchado A., Rebolo R., Gonzalez Hernandez J.I., Garcia-Hernandez D.A., Lambert D.L. A search for interstellar anthracene toward the Perseus anomalous microwave emission region// Monthly Notices of the Royal Astronomical Society, 2010,v.407(4), p.21572165. DOI: 10.1111/j.1365-2966.2010.17075.x

129. Iglesias-Groth S., Manchado A., Rebolo R., Gonzalez Hernandez J.I., Garcia-Hernandez D.A., Lambert D.L. Evidence for the Naphthalene 
Cation in a Region of the Interstellar Medium with Anomalous Microwave Emission I/The Astrophysical Journal,2008,v.685(1),p.55. DOI: $10.1086 / 592349$.

130. Kwok S., Zhang Y. Mixed aromatic-aliphatic organic nanoparticles as carriers of unidentified infrared emission features. //Nature, 2011,v.479, №3,p.80-83. DOI: 10.1038/nature10542.

131. Kwok S. Organic dust in the interstellar medium //Korean Astronomical Society, 2015,v.30(2), p.155-158. DOI: 10.5303/PKAS.2015.30.2.155

132. Kwok S., Zhang Y.Unidentified Infrared Emission Bands: PAHs or MAONs? //Astrophysical Journal, 2013,v.771(5), p.9.

133. Szczerba R., Omont A., Volk K., Cox P., Kwok S. IRAS $22272+5435$ - a source with 30 and $21 \mu \mathrm{m}$ features.// Astronomy and Astrophysics, 1997,v.317, p.859-870.

134. Cami J.,Bernard-Salas J.,Peeters E., Malek S. E. Detection of C60 and C70 in a Young Planetary Nebula.//Science,2010, v.329, issue 5996, p.1180-1182. DOI: 10.1126/science. 1192035

135. Karin O. I., Guzman V. V., Furuya K., Gi C., Aikawa Y., Andrews S. M.,Lomis R., Wilner D. J. The comet-like composition of a protoplanetary disk as revealed by complex cyanides.// Nature,2015,v.520,issue7546, p.198-201. DOI: 10.1038/nature14276.

136. M. A. Cordiner, H. Linnartz, N. L. J. Cox, J. Cami, F. Najarro, C. R. Proffitt, R. Lallement, P. Ehrenfreund, B. H. Foing, T. R. Gull Show Confirming Interstellar C60 + Using the Hubble Space Telescope//The Astrophysical Journal Letters,2019. v. 875, № 2.

137. Божокин С.В. Свойства космической пыли // Соросовский образовательный журнал, 2000, № 6, с. 72-77.

138. lett F. C., Forrest W. J., Merrill K. M. 8 - 13-micron spectra of NGC 7027, BD +30 3639, and NGC 6572. // Astrophys. J., 1973,v.183, p.87-93.

139. Oeberg K. I., Boogert A. C. A., Pontoppidan K. M. Van den Broek S., Van Dishoeck E.F., Bottinelli S., Blake G.A., Evans II N.J. The Spitzer Ice Legacy: Ice Evolution from Cores to Protostars // Astrophys. J., 2011, v.740,№2, p. 109(16pp). doi:10.1088/0004-637Х/740/2/109.

140. Третьяков Ю. Д. Низкотемпературные процессы в химии и технологии // Соросовский образовательный журнал, № 4, 1996.,с. 45-51.

141. Herbert L., Smith I.W.M, Spencer-Smith R.D.. Rate constants for the elementary reactions between $\mathrm{CN}$ radicals and $\mathrm{CH}_{4}, \mathrm{C}_{2} \mathrm{H}_{6}, \mathrm{C}_{2} \mathrm{H}_{4}, \mathrm{C}_{3} \mathrm{H}_{6}$, 
and $\mathrm{C}_{2} \mathrm{H}_{2}$ in the range: $295 \leqslant \mathrm{~T} / \mathrm{K} \leqslant 700 / /$ Int. J. Chem. Kinet.,1992,v.24, issue 2, p.791-802.

142. Sims I.R., Queffelec J.L., Travers D., Rowe B.R.,Herbert L.B., Karthauser J., Smith I.W.M.. Rate constants for the reactions of CN with hydrocarbons at low and ultra-low temperatures. //Chem. Phys. Lett, 1993, v. 211 , issue 4, p.461-468.

143. Shannon R.J, Blitz M.A, Goddard A, Heard D.E. Accelerated chemistry in the reaction between the hydroxyl radical and methanol at interstellar temperatures facilitated by tunnelling.// Nature Chemistry, 2013,v.5, p. 745-749, DOI:10.1038/nchem.1692

144. Гольданский В.И., Трахтенберг Л.И., Флеров В.Н. Туннельные явления в химической физике. М.: Наука, 1986. 296 с.

145. Делоне Н. Б. Туннельный эффект // Соросовский образовательный журнал, 2000, № 1, с.79-84.

146. Acharyya K, Herbst E, Caravan R.L, Shannon R.J, Blitz M.A, Heard D.E. The importance of $\mathrm{OH}$ radical-neutral low temperature tunnelling reactions in interstellar clouds using a new model.// Molecular Physics, 2015,v.113, p.2243-2254,DOI:10.1080/00268976.2015. 1021729.

147. Shannon R.J., Caravan R.L., Blitz M.A., Heard D.E. A combined experimental and theoretical study of reactions between the hydroxyl radical and oxygenated hydrocarbons relevant to astrochemical environments. //Physical Chemistry Chemical Physics, 2014, v.16, p.3466-3478. DOI:10.1039/c3cp54664k

148. Caravan R.L., Shannon R.J., Lewis T., Blitz M.A., Heard D.E. Measurements of Rate Coefficients for Reactions of $\mathrm{OH}$ with Ethanol and Propan-2-ol at Very Low Temperatures.//Journal of Physical Chemistry A , 2015, v.119, p.7130-7137. DOI:10.1021/jp505790m.

149. Jiménez E., Antiñolo M., Ballesteros B., Canosa A. Albaladejo, J. First evidence of the dramatic enhancement of the reactivity of methyl formate $\left(\mathrm{HC}(\mathrm{O}) \mathrm{OCH}_{3}\right)$ with $\mathrm{OH}$ at temperatures of the interstellar medium: a gas-phase kinetic study between $22 \mathrm{~K}$ and $64 \mathrm{~K} / /$ Phys. Chem. Chem. Phys, 2016, v.18 (3), p.2183-2191.

150. Barelko V. V., Kiryukhin D. P., Barkalov I. M., Kichigina G. A., Pumir A. Nonlinear traveling wave mechanisms of fast solid-phase cryochemical reactions.// Russian Chemical Bulletin, 2011, v.60, issue 7, p.1286-1289.

151. Отрощенко В. А., Алексеев В. А., Рябчук В. К. Неравновесные процессы синтеза органического вещества в межзвездных газо-пылевых облаках //Успехи биологической химии, 2002, т. 42, с. 295-320. 
152. Рюмин А.А., М.С. Копяткевич М.С., Грибков В.В. О типизации ванадиеносных нефтей.//Геология нефти и газа, 1989, №6.

153. Петров А.А., Бальян Х.В., Трощенко А.Т. Органическая химия: Учебник для вузов. М.: Высш.школа, 1981.592с.

154. Якуцени С.П. Распространенность углеводородного сырья, обогащенного тяжелыми элементами-примесями. Оценка экологических рисков. Спб.: Изд-во «Недра», 2005. 372 с.

155. Якуцени С.П. Глубинная зональность в обогощенности углеводородов тяжелыми элементами-примесями // Нефтегазовая геология. Теория и практика, 2010, т. 5, № 2. - http://www.ngtp.ru/rub/7/30_2010.pdf

156. Гамянин Г.Н., Горячев Н.А., Бахарев А.Г. и др. Условия зарождения и эволюции гранитоидных золоторудно-магматических систем в мезозоидах северо-востока Азии. Магадан: СВ КНИИ ДВО РАН, 2003. $196 \mathrm{c}$.

157. Ганжа Г.Б., Ганжа Л.М. Золото-битумная минерализация в черносланцевой толще, Центральная Колыма. //Руды и металлы, 2004, № 4, с. 24-32.

158. Озерова Н.А. Ртутоносность газовых и газонефтяных месторождений. В сб. Новые идеи в геологии и геохимии нефти и газа. К созданию общей теори и нефтегазоносности недр. М.: ГЕОС, Книга 2, 2002, c. $167-171$.

159. Wedepohl K. H. Geochemie (нем.). Berlin: Verlag Walter de Gruyter, 1967. 220 S. — (Sammlung Göschen, Bd 1224-1224a/1224b).

160. Крылова А. Ю., Куликова М. В., Лапидус А. Л. Катализаторы синтеза Фишера-Тропша для процессов получения жидких топлив из различного сырья // Химия твердого топлива, 2014. № 4,с. 18.

161. Лапидус А.Л., Локтев С.М. Современные каталитические синтезы углеводородов из окиси углерода и водорода // Журнал Всес. химического общества им. Д.И. Менделеева. 1986, т.31, №5, с.527-532.

162. Баренбаум А.А. Механизм формирования месторождений нефти и газа //ДАН, 2004, т.399, №6, с.802-805.

163. Петров М.Н., Михилев Л.А., Кукущкин Ю.Н. Неорганическая химия. Л.:Химия, 1976. 480с.

164. Никаноров А. М. Гидрохимия.-СПб: Гидрометеоиздат, 2001. $444 \mathrm{c}$.

165. Симонян Г.С. Арутюнян Н. М. Представление об аномальных и специфических свойствах воды. // Наука и образование сегодня,2018, № 4 (27), c.13-15. 
166. Latimer Wendell M., Rodebush Worth H. Polarity and ionization from the standpoint of the lewis theory of valence // J. Am. Chem. Soc,1920, v. 42, p. 1419-1433. DOI:10.1021/ja01452a015

167. Simonian G.S., Beylerian N.M. The solvent action on Michaelis reaction rate. A New Parameter concerning the solvent Polariti.//Oxidation Communication, 2003,v.26, №4,p.485-491.

168. Мосин О.В., Игнатов И. Структура воды // Химия, 2013, № 1, c. $12-32$.

169. Асхабов А.М. Нанокластерная модель образования жидкой воды //Известия Коми научного центра УРО РАН, 2016. №1.(25), с.6267.

170. Зенин С.В. Исследование структуры воды методом протонного магнитного резонанса // Докл. РАН, 1993, т. 332, № 3, с. 328-329.

171. Ривкин С.Л., Александров А.А. Теплофизические свойства воды и водяного пара. М.: Энергия, 1980. 424 с.

172. Летников Ф.А., Кащеева Т.В., Минцис А.Ш. Активированная вода.-Новосибирск: Наука, 1976. 135 с.

173. Блох А. М. Структура воды и геологические процессы. М.: Недра, 1969. 216 с.

174. Kolesnikov A.I., Reiter G.F., Choudhury N., Prisk T.R., Mamontov E., Podlesnyak A., Ehlers G., Seel A.G., D. Wesolowski D.J., Anovitz L.M. Quantum Tunneling of Water in Beryl: A New State of the Water Molecule.//Phys. Rev. Lett, 2016, v.116, p.167802.

175. Agrawal K.V., Shimizu S, Drahushuk L.W., Kilcoyne D., StranoM.S. Observation of extreme phase transition temperatures of water confined inside isolated carbon nanotubes//Nature Nanotechnology, 2017, v 12, p267-273.

176. Kilaj A., Gao H., Rösch D., Rivero U, Küpper J., Willitsch S Observation of different reactivities of para and ortho-water towards trapped diazenylium ions//Nature Communications, 2018, v. 9, p.2096. DOI: 10.1038/s41467-018-04483-3

177. Mamrashev A.A., Maximov L.V., Nikolaev N.A., Chapovsky P.L. Detection of Nuclear Spin Isomers of Water Molecules by Terahertz TimeDomain Spectroscopy//IEEE Transactions on Terahertz Science and Technology, 2018, v. 8, issue 1, p. 13-18.

178. Mpemba E.B., Osborne D.G. Cool?// Physics Education,1969, v.4, № 3, p. 172-175. doi.org/10.1088/0031-9120/4/3/312.

179. Симонян Г.С. Вклад химиков в развитии абиогенной теории образования нефти // Итоги первой пятилетки Кудрявцевских Чтений: от теории неорганического происхождения к практике поисков глубин- 
ной нефти. 6-е Кудрявцевские Чтения. Материалы Всероссийской конференции по глубинному генезису нефти и газа. Москва, 22-24 октября 2018 г. М.: ГН, 2018, с.334-339.

180. Симонян Г.С. Роль химиков в развитии нефтегазовой отрасли и абиогенной теории образования нефти Булатовские чтения: материалы III Международной научно-практической конференции (31 марта 2019 г.): в 5 т.: сборник статей / Под общ. ред. д-ра техн. наук, проф. О.В. Савенок. - Краснодар : Издательский Дом - Юг.Т. 5: Технические и технологические разработки. Электрооборудование в нефтегазовой отрасли. Гуманитарные науки, 2019, с.120-123.

181. Simonian G. Chemical processes of abiotic oil formation // GISAP: Physics, Mathematics and Chemistry, 2015, №7, p. 10-13.

182. Малышев А.И. Сера в магматическом рудообразовании. Екатеринбург: Институт геологии и геохимии УрО РАН, 2004. 189с.

183. Симонян Г.С. Конденсационные процессы меркаптанов при трансформации нефти в воде // Современные наукоемкие технологии, 2014, №4, c. 175.

184. Сорохтин О.Г., Ушаков С.А. Развитие Земли. М: МГУ, 2002. $506 \mathrm{c}$.

185. Kaminsky F., Wirth R. Nitrides and carbonitrides from the lowermost mantle and their importance in the search for Earth's «lost» nitrogen // American Mineralogist, 2017, v.102, issue.8, p. 1667-1676. DOI: 10.2138/am-2017-6101.

186. Зорькин Л.М. Геохимия газов пластовых вод нефтегазоносных бассейнов. - М.: «Недра», 1973, стр. 204.

187. Яновская С.С., Сагаченко Т.А., Шикалин А.В., Сереьрянникова О.В. Азот в рассеянном органическом веществе и нефтях верхней юри западной Сибири. - Известия Томского политехнического университета, 2006, т.309, № 1, с. 40-46.

188. Маракушев А.А, Маракушев С.А. Природа геохимической специфики нефти // ДАН, 2006, т.411, № 1, с.111-117.

189. Герасимова Н.Н., Сагаченко Т.А. Азоторганические соединения в нефтях юрско-палеозойских отложений Западной Сибири и факторы, влияющие на их распределение и состав. - Сборник докладов Всероссийской научной конференции «Успехи органической геохимии»,Новосибирск, 2010, с.85-89

190. Dillion T., Jeanzol R. High pressure temperature phase of iron nitride:Preliminary results.//Abstr. AGU Meet., San Francisco, Calif., Dec. 711, 1992. - Eos 1992, v. 73, № 43, p.64. 
191. Андриевский Р.А., Урбанович В.С., Кобелев Н.П., Торбов В.И. Высокотемпературная консолидация и физико-механические свойства нанокристаллического нитрида титана //Докл. РАН, 1997, т.356, №1, с. 39-41.

192. Zhang J., Oganov A. R., LI X., NIU H. Pressure-stabilized Hafnium Nitrides and Their// Properties. Phys Rev, 2017, B 95, 020103(R) https://doi.org/10.1103/PhysRevB.95.020103.

193. Kvashnin A.G., Oganov A.R., Samtsevich A.L., Allahyari Z Computational Search for Novel Hard Chromium-Based Materials. J. Phys. Chem. Lett., 2017, v.№8 (4), p. 755-764. DOI: 10.1021/acs.jpclett.6b02821

194. Qian G.R., Niu H.,Hu C.H.,Oganov A.R., Zeng Q., Zhou H.Y. Diverse Chemistry of Stable Hydronitrogens, and Implications for Planetary and Materials// Sciences. Sci Rep, 2016, №6, p.25947. DOI: 10.1038/srep25947.

195. Зубков В.С. К вопросу о составе и формах нахождения флюида системы C-H-N-O-S в РТ-условиях верхней мантии.// Геохимия, 2001, № 2, с. 131-145.

196. Marty, B. and Dauphas, N. The nitrogen record of crust-mantle interaction and mantle convection from Archean to Present.//Earth and Planetary Science Letters, 2003, v. 20, p. 397-410.

197. Симонян Г.С. Роль мантийного азота в нефтеобразовании. Природные физико-химические условия и процессы преобразования и мобилизации мантийных C-H-N-O-S систем в углеводороды нефтяного ряда. Исходное вещество и очаги генерации, механизм и каналы вертикальной миграции глубинной нефти. -2-е Кудрявцевские Чтения. Материалы Всероссийской конференции по глубинному генезису нефти и газа. М.: ЦГЭ, 2013, с.293-296.

198. Лапидус А.Л., Елисеев О.Л., Крючков М.В. Получение углеводородов из синтез-газа, забалластированного азотом.//Технологии нефти и газа, 2011, №5, с. 9-12.

199. Шарапов В.Н., Ионе К.Г., Мазуров М.П. и др. Геокатализ и эволюция мантийно-коровых магматогенных флюидных систем. Новосибирск:Гео, 2007. 192с.

200. Несмиянов А.Н., Несмиянов Н.А. Начала Органической химии. М.: Химия, 1970, т.2. 824c.

201. Химия алкенов. (под ред. С.Патая). Л.: Химия, 1969. 260с.

202. Симонян Г.С., Бейлерян Н.М., Пирумян Э.Г., Рок Ж-П, Буае Б. Влияние растворителя и строения аминов на скорость взаимодействия $\alpha, \beta$-ненасыщенных нитрилов и амидов кислот со вторичными аминами. //Кинетика и катализ, 2001, т.42, №4, с.527-531. 
203. Simonian G.S., Beylerian N.M., Pirumyan E.G., Roque J-P., Boyer B. Quantitative Estimation of Physico-Chemical Activation of Reaction $\alpha, \beta$ Unsaturated Compounds+Secondary Amines.//Oxidation Communication, 2001,v.24, №2, p.235-240.

204. Beylerian N.M., Simonian G.S. Kinetic Study of reactions $\mathrm{R}_{2} \mathrm{NH}+\alpha, \beta$-unsaturated compound.The rate dependence on reagents structure and solvents nature.Quantitative study of some amines reactivity toward peroxides and ROO.,HO. Free radical.// In Trends in Molecular and High Molecular Sciense, New-York "Nova Scien.Pub.Inc." 2005, ch.12,p.199216.

205. Simonian G.. Beylerian N. The Michaelis condensation in conditions of inverse transfer catalysis.Kinetic study.-Oxidation Communication, 2010, v.33, №1, p.125-131.

206. Симонян Г.С., Пирумян Г.П. Новый подход к автокатализу при изучении конденсации михаэля в модельной двухфазной системе нефть - вода. //Экологическая химия, 2010, т.19, вып.3, с.168-171.

207. Симонян Г.С., Бейлерян Н.М., Саруханян Э.Р., Асатурян Р.А., Мелконян Р.Г. О кинетике и механизме реакций винилацетата с диэтиламином, пиперидином и морфолином.//Кинетика и катализ, 1999, т.40, №4, c.578-582.

208. Симонян Г.С. Влияние аминоспиртов на скорость полимеризации акрилонитрила, инициированной пероксидом бензоила, и на термостабильность полиакрилонитрила. -Физико-химия полимеров, Тверь 2004. вып.10. с.206-208.

209. Симонян Г.С., Акопян Р.М., Бейлерян Н.М. Система пероксид - продукт реакции диэтаноламин - акрилонитрил, диэтаноламин - акриламид иницииаторы радикальной полимеризации.//Арм.хим.ж., 1991, т.46, №6, с.336-340.

210. Симонян Г.С., Согомонян Б.М., Бейлерян Н.М. О роли воды в инициировании цепи системой пероксид бензоила - третичный аминоспирт при полимеризации акрилонитрила в диметилформамиде.//Кинетика и катализ, 1987, т.28, вып.1, с.198-201.

211. Неорганическая химия/ под ред. Акад. Д. Третякова/ том 3, Химия переходных элементов.-М., Академия, 2007, книга 1, т.3, 352c.

212. Гилинская Л.Г. Спектры ЭПР комплексов V(IV) и структура нефтяных порфиринов // Журн. структурной химии, 2008, т. 49, № 2, с. 259-268.

213. Холодов В.Н. Осадочный рудогенез и металлогения ванадия. М., Наука, 1973. 275 с. 
214. Якуцени С.П. Распространенность углеводородного сырья, обогащенного тяжелыми элементами-примесями. Оценка экологических рисков. Спб., Недра, 2005. 372 с.

215. Якуцени С.П. Глубинная зональность в обогощенности углеводородов тяжелыми элементами-примесями // Нефтегазовая геология. Теория и практика, 2010, т. 5, № 2. http://www.ngtp.ru/rub/7/30_2010.pdf

216. Насиров Р.Н., Солодовников С.П., Якуцени С.П. Сопоставление результатов определения ванадия в нефтях методами ЭПР и ФРРА //Нефтяное хозяйство, 1992, №10, с. 27-28.

217. Те Л. А., Насиров Р., Джексенов М. К., Куспанова Б. К. Использование парамагнитных центров пород для поисков залежи -нефти и газа // Южно-Российский вестник геологии, географии и глобальной энергии, 2003, №3, с. 24-26.

218. Симонян Г.С. Перспективы получения металлов из нефти «Инновационные технологии и проекты в горно-металлургическом комплексе, их научное и кадровое сопровождение» Сборник трудов Международной научно-практической конференции. Гл. ред. Ж. М. Адилов - Алматы: КазНТУ, 2014, с.446-449.

219. Симонян Г.С. Металлоносность и азотсодержание нефтей как генетические характеристики. Современные проблемы регионального развития: V международная научно-практическая конференция. Биробиджан, 9-11 сентября 2014 г. /Под ред. Е.Я.Фримана. Биробиджан ИКАРП ДВО. ВАИ-ФГБОУ ВПО « ПГУ им. Шалом-Алейхома»,2014, с.189-190.

220. Симонян Г.С. Роль ванадия в генезисе нефти. Международной научно практическаой конференции «АУЭЗОВСКИЕ ЧТЕНИЯ-12». «Роль регионального университета в развитии инновационныхнаправлений науки, образования и культуры»- Шымкент:ЮКГУ им. М.Ауэзова, 2014,с.117-119

221. Абызгильдин Ю.М., Михайлюк Ю.И., Яруллин К.С., Ратовская А.А. Порфирины и металлопорфириновые комплексы нефтей. М., Наука, 1977.88 с.

222. Аскаров К.А., Березин Б.Д., Евстигнеева Р.П. и др. Порфирины: структура, свойства, синтез. М., Наука,1985. 333 с.

223. Thauer R.K. Biochemistry of Methanogenesis: a Tribute to Marjory Stephenson //Microbiology journal,1998,v.144, №9, p.23772406.doi:10.1099/00221287-144-9-2377

224. Стид Дж.В., Этвуд Дж.Л. Супрамолекулярная химия/перевод с английского/ М., ИКЦ Академия, 2007,т.1, 480 с. 
225. Мираламов Г. Ф.,Мамедов Ч.И. Каталитическое эпоксидирование олефинов в присутствии ванадилпорфиринового комплекса.// Нефтехимия, 2006, т. 46, №1, с. 28-30.

226. Мираламов Г. Ф. Димеризация 1-бутена в присутствии каталитической системы никель-порфириновый комплекс и бутиллития // Нефтегазовые технологии, 2005, №1, с. 72-73.

227. Микенин П.Е., Цырульников П.Г., Котолевич Ю.С., Загоруйко A.Н. Ванадий-оксидные катализаторы селективного окисления сероводорода на основе структурированных микроволокнистных носителей// Международная конференция «Каталитические процессы нефтепереработки, нефтехимии и экологии» октябрь 2013, Ташкент, Республика Узбекистан: сборник тезисов докладов изд Институт катализа СО РАН, Новосибирск, Россия, 2013,с. 54-55.

228. Olsbie U., Wurzel T., Mleczko L. Ind.Eng.Chem.Res., 1997, v. 36, № 12 , p. $5180-5188$.

229. Агугусейнова М.М., Абдуллаева Г.Н. Каталитическое оксигенирование олефинов нефтяными металлопорфиринами. //Изв. ВУЗов, сер. химия и химическ. Технология, 2010, т. 53, вып.9, с.12-15.

230. Морозов В.П., Кольчугин А.Н.Учебно-методическое пособие к лабораторным занятиям по курсу «Нефтегазовая литология» . Казань: Казанский университет, 2012. 25 с.

231. Латышев О. Г., Корнилков М. В. Направленное изменение фрактальных характеристик, свойств и состояния пород поверхностноактивными веществами в процессах горного производства: научная монография. Екатеринбург: Изд-во УГГУ, 2016. 407 с.

232. Хант Дж. "Геохимия и геология нефти и газа" М., Мир, 1982. $704 \mathrm{c}$.

233. Конторович А. Э., Нестеров И. И., Салманов Ф. К. и др. Геология нефти и газа Западной Сибири. М.: Недра, 1975. 680 с.

234. Симонян Г.С., Пирумян Г.П. Определение показателей почви в системе агроэкологического мониторинга / Учебно-методическая работа / Ереван. ЕГУ, 2011, 44 с.(на армянском)

235. Тарасевич Ю.И., Овчаренко Ф.Д. Адсорбция на глинистых минералах. Киев: Наук. думка, 1975. 350 с

236. «Классификация запасов и прогнозных ресурсов нефти и горючих газов», утверждённая приказом № 298 МПР РФ от 1 ноября 2005 г.

237. Сафиева Р.З. Химия нефти и газа. Нефтяные дисперсные системы: состав и свойства (часть 1). Учебное пособие. М.: РГУ нефти и газа им. И.М.Губкина, 2004.112с. 
238. Земенков Ю.Д., Александров М.А., Маркова Л.М., Дудин С.М., Подорожников С.Ю., Никитина А.В. Техника и технологии сбора и подготовки нефти и газа: Учебник. Тюмень: Издательство, 2015. 160 с.

239. Ребиндер П.А. Взаимосвязь поверхностных и объемных свойств рас-творов поверхностно-активных веществ // Успехи коллоидной химии. М.: Наука, 1973, с.9-68.

240. Абрамзон А. А. Поверхностно-активные вещества: Свойства и приме-нение. Л.: Химия, 1981. 304 с.

241. Карпов В.А. Об особом типе скоплений трудноизвлекаемых запасов УВ //Недропользование XXI век, 2016, № 3, с. 132-139.

242. Карпов В.А. Залежи водонефтяных эмульсий - природные объекты //Недропользование XX1 век, 2016, № 5, . 184-188.

243. Карпов В.А. Еще раз о необходимости поиска эмульсионных скоплений УВ //Недропользование XXI век, 2016, № 6, с. 134-139.

244. Галлямов Р.Н. Газовые гидраты - топливо будущего? //Сборник трудов 72-й Международной молодежной научной конференции «Нефть и газ - 2018». М.: Издательский центр РГУ нефти и газа имени И.М. Губкина, 2018, с.67-73.

245. Симонян Г.С., Айрапетян М.К., Давтян Л.Г. Газовые гидраты в природе // Теоретические и прикладные вопросы науки и образования: по материалам международной научно-практической конференции 31 января 2020 г. Вестник научных конференций, 2020, № 1-2(53), с.100101.

246. Ширшова Альбина Вольфовна (RU) Данько Михаил Юрьевич (RU) Способ утилизации попутного нефтяного газа RU 2488625: Способ утилизации попутного нефтяного газа путем перевода его в газогидрат в водонефтяной

247. Иванова И.К., Семенов М.Е., Корякина В.В., Рожин И.И. Определение Р-Т - области устойчивости гидратов природного газа в эмульсиях парафинистой нефти //Успехи современного естествознания, 2016, № 10, c. 36-41.

248. Шабаров А.Б., Ширшова А.В., Гашева С.С. Влияние физикохимических свойств нефти на газогидратообразование в водонефтяных эмульсиях.// Известия высших учебных заведений. Нефть и газ, 2014, №2, c.88-93.

249. Stoporev A.S., Ogienko A.G., Sizikov A.A., Semenov A.P., Kopitsyn D.S., Vinokurov V.A., Svarovskaya L.I., Altunina L.K., Manakov A.Yu. Unexpected formation of sII methane hydrate in some water-in-oil emulsions: Different reasons for the same phenomenon//Journal of Natural Gas Science and Engineering, 2018,v. 60, p. 284-293. 
250. Устьянцев В.Н. Энергетика, дегазация автоколебательной системы Земли. О едином волновом механизме структурообразования и генерации минералогических ассоциаций в блоках земной коры. М.: Наука, 2019. 390 с. - ISBN 978-5-02-040199-0.

251. Виноградов А.П. Поиски рудных месторождений по растениям и почвам. //Тр. биогеохим. лаб., 1954, № 10, с. 3-27.

252. Матвеев А.А. Геохимические поиски месторождений полезных ископаемых. Краткий курс лекций. Учебное издание.М.: Изд-во МГУ, 2003. $110 \mathrm{c}$.

253. Сауков А.А. Геохимические методы поисков месторождений полезных ископаемых. М., МЕУ, 1963. 248с.

254. Соловов А.П. Геохимические методы поисков месторождений полезных ископаемых. М., Недра, 1985. 294 с.

255. Соколов В.А. Прямые геохимические методы поисков нефти и газа. М., Гостоптехиздат, 1947. с.47-59.

256. Кузнецова И.А., Холостов С.Б. Листостебельные мхи как биоиндикаторы нефтяного загрязнения природной среды района падения отделяющихся частей ракет-носителей // Успехи современного естествознания. - 2013. - № 6. - С. 98-101.

257. Сочеванов Н.Н., Стеценко В.С., Чекунов А.Я. Использование биолокационного метода при поисках месторождений и геологическом картировании. Монография. М: Радио и связь, 1984. 56с.

258. Андреев Н. М. Биолокация как метод геофизики. - Тезисы докладов Международной конференции ИНЖЕНЕРНАЯ ГЕОФИЗИКА2009. Геленджик, 2009. http://rel-mgrt.narod.ru/BiolocGeophis.htm

259. Андреев Н. М. Эффективное дополнение к методам поисков месторождений нефти. - Тезисы докладов школы-семинара "Электромагнитные исследования в Восточной Сибири". ФГУП "СНИИГГиМС". Новосибирск, 2010. http://rel-mgrt.narod.ru/BGF_Dokl_Nsib.htm

260. Андреев Н. М. Технология поисков и разведки месторождений УВ на основе БГФ метода. - Тезисы докладов 1-х Кудрявцевских чтений. Москва, 2012. Андреев Н. М. Картирование зон локализованной разгрузки УВ в земной коре БГФ методом. //Тезисы докладов 2-х Кудрявцевских чтений. Москва, 2013.

261. Андреев Н. М. Структура очагов локализованной разгрузки глубинных флюидов по данным их картирования БГФ методом. //Тезисы докладов 3-х Кудрявцевских чтений. Москва, 2014.

262. Андреев Н. М. Электроразведка МПП при поисках подземных вод в горных районах и биолокация. //Тезисы докладов 6-го Международного геофизического научно-практического семинара "Применение современных электроразведочных технологий при поисках месторож- 
дений полезных ископаемых". Санкт-Петербург, 2008. http://relmgrt.narod.ru/MPPibioloc.htm

263. Андреев Н. М. Технология поисков подземных вод в самых сложных условиях горных территорий и городской застройки с применением нетрадиционных методов. - Тезисы докладов Международной научно-практической конференции ИНЖЕНЕРНАЯ ГЕОФИЗИКА2011. Москва, 2011. http://rel-mgrt.narod.ru/files/Tezisyeg2011.pdf

264. Андреев Н. М. Нефтепоисковая технология СГТ ДЗ как инструмент изучения механизма формирования и прогнозирования активности вулканов //Тезисы докладов 7-х Кудрявцевских чтений. Москва, 2019.

265. Тимурзиев А.И. Прогнозирование нефтегазоносности на основе связей физических полей с новейшими структурами земной коры. // Геология нефти и газа, 2004, №4, с.39-51.

266. Тимурзиев А.И. Структура проницаемости земной коры и технологическое решение проблемы картирования очагов локализованной разгрузки глубинных флюидов - Тезисы докладов Всероссийской конференции «Фундаментальный базис новых технологий нефтяной и газовой промышленности. Теоретические и прикладные аспекты». М., ГЕОС, 2007, с. 238-239.

267. Тимурзиев А.И. Новейшая сдвиговая тектоника осадочных бассейнов: тектонофизический и флюидодинамический аспекты (в связи с нефтегазоносностью). Часть 1. Электронный журнал "Глубинная нефть", 2013, т. 1, №4, с. 561-605.

268. Шумейкин А.С., Тимурзиев А.И. Методика комплексирования аэрокосмических, грави-магнитометрических и топогеодезических данных при поисках и разведке залежей УВ в пределах Западной Сибири. Тезисы докладов Международной научно-технической конференции «Аэрокосмические технологии в нефтегазовом комплексе». М, РГУ им. И.М.Губкина, 2009, с.192-193 (http://deepoil.ru/images/stories/docs/avtorsk/raboty/txt_B_116.pdf).

269. Тимурзиев А.И., Шумейкин А.С. Результаты комплексирования аэрокосмических, грави-магнитометрических и геоморфологических методов при поисках и разведке залежей УВ в пределах Западной Сибири. - Тезисы докладов Международной научно-технической конференции «Аэрокосмические технологии в нефтегазовом комплексе». М, РГУ им. И.М.Губкина, 2009, с.168-169 (http://deepoil.ru/images/stories/docs/avtorsk/raboty/txt_B_111.pdf).

270. Тимурзиев А.И., Шумейкин А.С., Шумейкин С.А. Методика прогноза нефтегазоносности недр на основе глубинно- фильтрационной модели нефтегазообразования и нефтегазонакопления // 1-е Кудрявцев- 
ские Чтения. Современное состояние теории происхождения, методов прогнозирования и технологий поисков глубинной нефти. Материалы Всероссийской конференции по глубинному генезису нефти. М.:, ЦГЭ, 2012, c.492-496

271. Тимурзиев А.И., Шумейкин А.С. Прогнозирование нефтегазоносности недр и методика поисков месторождений на основе глубиннофильтрационной модели нефтегазообразования и нефтегазонакопления. //Геология, геофизика и разработка нефтегазовых месторождений, 2010, №9, c. 22-29. (http://deepoil.ru/images/stories/docs/avtorsk/raboty/txt_B_64.pdf).

272. Тимурзиев А.И., Шумейкин А.С., Шумейкин С.А. Методы и технологии оценки перспектив нефтегазоносности территорий на основе комплексного анализа потенциальных полей, данных сейсморазведки, топогеодезической и космической съемки. //Электронный журнал «Глубинная нефть», 2014, т. 2. №3. c. 307-340 (http://journal.deepoil.ru/images/stories/docs/DO-2-3-2014/2_Timurziev-Shumeikin-Shumeikin_2-32014.pdf).

273. Багдасарова М.В. Механизм формирования месторождений углеводородов и новые критерии их поисков.//Электронный журнал "Глубинная нефть", 2013, т. 1, №4, с. 502-513.

274. Зинатов Х.Г. Усовершенствование тектонических предпосылок поисков месторождений неметаллов и лигнитов в неотектонических орогенах. //Электронный журнал «Глубинная нефть», 2013, т. I, № 9, с. 1285-1306.

275. Зинатов Х.Г. Применение тектонофизических методов при усовершенствовании тектонических предпосылок поисков месторождений углеводородов.// Материалы Конференции ИФЗ «Четвертая ТК 2016» Тектонофизика в решении проблем поиска и безопасной разработки месторождений полезных ископаемых, 2016, с.51-59. http://www.ifz.ru/lab_204/konferencii/chetvertaja-tk-2016/materialy-konf/razdel

276. Зинатов Х.Г Методология и методика усовершенствования тектонических критериев прогноза и поисков месторождений горючих и неметаллических полезных ископаемых // Итоги первой пятилетки Кудрявцевских Чтений: от теории неорганического происхождения к практике поисков глубинной нефти. 6-е Кудрявцевские Чтения. Материалы Всероссийской конференции по глубинному генезису нефти и газа. Москва, 22-24 октября 2018 г. М.: ГН. 2018. с.148-161.

277. Зинатов Х.Г. Поля напряжений - ведущие факторы образования, сохранности и разрушения месторождений эндогенных промышленных месторождений неметаллов в центральной части Алданского 
щита и их применение в геодинамических и прогнозно-поисковых исследованиях. //Электронный журнал "Глубинная нефть", 2013, т. 1, №5. c. 660-683. http://journal.deepoil.ru/images/stories/docs/DO-1-5-2013/6_Zinatov_1-5-2013.pdf

278. Дроздовская А.А., Шевченко Н.Б., Сухомлинов Ю.А. Геоэтическая значимость применения биолокационного метода для поиска флюидных скоплений в зонах релаксации геодинамических напряжений// Доклад/ In: The Mining Pribram symposium. International section G16. Prague. October 4-8, 1999. G16, p. 1-5.

279. Шевченко Н.Б., Колос В.Я., Сухомлинов Ю.А., Фиалко А.И. Предполагаемая зона нефтегазонакопления в породах эпигерцинского фундамента Среднеазовского фундамента//Научно-практический дискуссионно-аналитический сборник "Вопросы развития Крыма". Симферополь: Таврия-Плюс, 2001, с.156-160.

280. Симонян Г.С. Новый механизм образования твердой корки на границе вода-нефть в нефтяном коллекторе. // Международный журнал прикладных и фундаментальных исследованый, 2013, №10, ч. 3, с.505.

281. Головина Ю.А. Особенности обводнения скважин пласта Б Северо-Каменского месторождения. Ашировские чтения: Сб. трудов Международной научно-практической конференции. Том II / Отв. Редактор В.В. Живаева/. Самара: Самар. гос. техн. ун-т, 2012, с.114-125.

282. Симонян Г.С. Геоэкологические аспекты повышения нефтеотдачи пластов Проблемы и перспективы развития геологического кластера: Образование-наука-производство: труды Международ. науч.-практ. конф., Алматы, 7-8 февраля 2014 г.Алматы: КазНТУ, 2014, с. 62-65.

283. Sandiford B.B. Laboratory and Field Studies of water Floods using Polymer solutions to increase Oil Recjvery. Journal of Petroleum Technology, 1964, v.16, №8, p.917-922.

284. Бехтерев Л.А., Васильев В.И., Власов С.А., Каган Я.М. Особенности применения осадкообразующих составов на основе биополимера Продукт БП-92 для выравнивания профилей приемистости нагнетательных скважин. Вестник ЦКР Роснедра, 2009, №1, с.53-59.

285. Nikolaevskiy V.N., Lopukhov G.P., Liao Yizhu, Economides M.J. Residual Oil Reservoir Recovery With Seismic Vibrations// SPE Production \& Facilities, 1996, v.11, issue 02. https://doi.org/10.2118/29155-PA

286. Бажалук Я.М., Карпаш О.М., Клымышин Я.Д., Гутак А.И., Худин Н.В. Увеличение отбора нефти путем воздействия на пласты пакетами упругих колебаний // Электронный научный журнал «Нефтегазовое дело», 2012, №3. http://www.ogbus.ru 
287. Кравцов Я.И., Марфин Е.А., Абдрашитов А.А. Повышение эффективности метода парогравитационного дренажа за счет волнового воздействия на пласт // Геология, геофизика и разработка нефтяных и газовых месторождений, 2016, №5, с.35-39. http://dspace.kpfu.ru/xmlui/handle/net/104535

288. http://deepoil.ru/forum/index.php?topic=261.msg12066\#msg12066

289. http://deepoil.ru/forum/index.php?topic=261.msg12068\#msg12068

290. Патент РА. АМ20120057, 2012, №2682А (Г. Симонян Э. Пирумян Л., Маргарян С. Григорян, Г. Пирумян) Метод обнаружения нефтяных залежей).

291. Патент РФ, RU 2417387 C2.

292. Моисеенко Т.И. Экотоксикологический подход к оценке качества вод // Водные ресурсы, 2005, т. 32, № 4, с. 410-424

293. Моисеенко Т.И., Гашкина Н.А., Шарова Ю.Н., Покоева А.Г. Экотоксикологическая оценка последствий загрязнения вод р. Волга и критических уровней // Водные ресурсы, 2005, т. 32, № 4, с. 1-15

294. Бутаев А.М.,Гуруев М.А.,Магомедбеков У.Г.,Осипова Н.Ф., Магомедрасулова Х.М., Магомедова А.Д., Мухучев А.А., Тяжелые металлы в речных водах Дагестана //Вестник Дагестанского научнего центра, 2006, № 26, с.43-50.

295. Каграманов Ю.Р. К проблеме преспектив нефтегазоносности Арарат-Арагацской впадины. Ереван, Астхик, 2010, 141с.

296. http://yerkramas.org/article/87895/specialisty-bleksterz-enerdzhiuvereny--chto-najdut-v-armenii-neft-i-gaz

297. https://ru.armeniasputnik.am/economy/20191110/21056217/VArmenii-est-neft-i-gaz-pochemu-biznesmen-zhaluetsya-i-na-prezhnie-vlastii-na-Pashinyana.html

298. https://finport.am/full_news.php?id=31496\&lang=2

299. https://ru.armeniasputnik.am/columnists/20190722/19723400/Neft -i-gaz-v-Armenii-Ne-vopros---Dzhordzh-Chilingar-bralsya-ikh-nayti.html

300. Мандельброт Б. Фрактальная геометрия природы. М.: Институт компьютерных исследований, 2002, 656 с.

301. Mandelbrot B. B. Les Objects Fractals: Forme, Hasard et Dimension. Paris: Flammarion, 1975. 192 p.

302. Григорьев Д.П. О различии минералогических терминов: скелет, дендрит и пойкилит. //Изв. Вузов, геол. и разв, 1965, №8, с.145-147.

303. Третьяков Ю.Д. Дендриди, фракталы и материали.//Соросовский $\square$ образовательный $\square$ журнал, 1998, №12, с.96-102.

304. Симонян Г.С. Фрактальность химических соединений. Peerreviewed materials digest (collective monograph) published following the 
results of the CXV International Research and Practice Conference and III stage of the Championship in Physics and Mathematics, Chemistry, Earth and Space Sciences (London, December 18- December 24, 2015) /International Academy of Science and Higher Education (London, UK)Published by IASHE London, 2016, p.11-13.

305. Запивалов Н.П., Попов И.П. Флюидодинамические модели залежей нефти и газа. Новосибирск: СО РАН, филиал "Гео", 2003. 198 с.

306. Запивалов Н.П., Смирнов Г.И. О фрактальной структуре нефтегазовых месторождений. //Докл. РАН, 1995, т. 341, №1, с.110-112.

307. Леванова Е.В. Результаты анализа выработки горизонтов Д $Д_{0}$ по различным объектам Ромашкинского месторождения для различных параметров разработки. //Известия высших учебных заведений. Нефть и газ, 2011, № 4, с.40-47.

308. Леванова Е.В. Фрактальный анализ основных показателей разработки объектов терригенных отложений девона Ромашкинского месторождения с. Ашировские чтения: Сб. трудов Международной научно-практической конференции. Том II / Отв. редактор В.В. Живаева/. Самара: Самар. гос. техн. ун-т, 2012, с. 254-256.

309. Мальшаков А.В. Самоподобная (фрактально-перколяционная) структура залежей углеродов. //Вестник КРСУ, 2009, т.9, № 11, с.123127.

310. Симонян Г.С. Фрактальность нефтяных залежей и нефти // Технология нефти и газа. 2015. №3 с.24-31.

311. Симонян Г. С. Фрактальность руд и нефтяных залежей Сборник научных докладов Современная наука. Новые перспективы Бы́дгощ (30.01.2014 - 31.01.2014 ) - Warszawa: Wydawca: Sp. z o.o. «Diamond trading tour $\gg, 2014$, S. 56-60.

312. Вадковский В.Н., Захаров В.С. Динамические процессы в геологии: первое знакомство с нелинейными системами. В сборнике 7-ая Международная конференция по тектонике плит им. Л.П. Зоненшайна, Москва, 2001, с.161-163.

313. Шестопалов А.В. Концепция геотехнологии промысловой добычи метана и угля исключительно за счет энергии природных сил. / Доклад на Международном симпозиуме "Неделя горняка 1999", Семинар 20 "Физико-химическая геотехнология" (Москва, МГГУ, 25.0129.01.1999г.). // Горный информационно-аналитический бюллетень, 1999, №2, c.154-159.http://www.barodinamika.ru/sh/139_.zip

314. Шестопалов А.В. О фрактальности механизма газовыделения из угольного пласта на малых и больших глубинах. / Доклады научного симпозиума "Неделя горняка - 2000", семинар N6 "Проблемы угольного 
метана" (31.01-04.02.2000г., МГГУ, г.Москва) - Горный информационно-аналитический бюллетень, 2000, №7, c.198-202.http://www.barodinamika.ru/sh/147_.zip

315. Шестопалов А.В. Процессовые фракталы и альтернативная термодинамика для синергетики. - Синергетика. / Труды семинара "Синергетика" и материалы конференции "Самоорганизация и синергетика" посвященой памяти чл.-корреспондента РАН, академика РНАН С.П. Курдюмова и академика РНАН, проф. МГУ А.П. Руденко (2425.02.2005г., Москва, МГУ). - М.: РНАН, 2006, с.200-214.

316. Головина Ю.А. Особенности обводнения скважин пласта Б口 Северо-Каменского месторождения. Ашировские чтения: Сб. трудов Международной научно-практической конференции. Том II / Отв. редактор В.В. Живаева/. Самара: Самар. гос. техн. ун-т, 2012, с.114-125.

317. Басииев К. С, Кочина И. Н., Максимов В. М. Подземная гидромеханика: Учебник для вузов.М.: Недра, 1993. 416 с.

318. Гачаев А.М. О фрактальной структуре нефтегазовых месторождений. //Инженерный вестник Дона, 2011, т. 15, № 1, с. 540-549.

319. Митюшин А. И., Разбегина Е. Г. Фрактально-статистический анализ процесса добычи углеводородов: учебное пособие. М.: МАКС Пресс, 2010. 110 c.

320. Лобов А.И., Заикин Н.П., Липский Л.А. Управление геодинамическими параметрами нефтяного пласта для оптимизации процессов испытания скважин и разработки месторождений//Проблемы освоения ресурсов нефти и газа Беларуси и пути их решения. Материалы научнопрактической конференции (22-24 мая 2002 г.). Гомель: РУП ПО “Белоруснефть”, 2003, с. 431-436.

321. Lenormand L.,Zarkone C. Two-phase flow experiments in twodimensional permeable medium. //Physicochem.Hydro, 1985, v.6, p.5-6.

322. Носков М.Д., Истомин А.Д. Стохастически - детерминистическое моделиро-вание неустойчивого вытеснения несмешивающихся жидкостей. //Математическое моделирование, 1999, т.11, №10, с.77-85.

323. Тарасевич Б.Н. О фрактальной структуре межфазных слоев. //Вести. Моск. ун-та. Сер. 2, Химия, 1998, t.38, с.132-133.

324. Сафиева Р.3. Физико химия нефти. М.: Химия, 1998. 448c.

325. Ting P.D., Hirasaki G.J., Chapman W.G. Modeling of Asphaltene Phase Behavior with the SAFT Equation of State. Petroleum Science and Technology, 2003,v.21(3-4), p.647-661.

326. Rogel E. Studies on asphaltene aggregation via computational chemistry. // Colloids and Surfaces A. Physicochemical and Engineering Aspects, 1995, v.104, p.85-93. 
327. Евдокимов И.Н. Комплект учебных пособий по программе магистерской подготовки «Нефтегазовые нанотехнологии для разработки и эксплуатации месторождений». Ч. 4. Проблемы несовместимости нефтей при их смешении: Учеб. пособие. М.: РГУ нефти и газа им. И.М. Губкина, 2008. 93 с.

328. Евдокимов И.Н., Лосев А.П. Комплект учебных пособий по программе магистерской подготовки «Нефтегазовые нанотехнологии для разработки и эксплуатации месторождений». Ч. 1. Материалы научно-технических конференций (2003-2006 гг., на русском языке): Учеб. пособие. М.: РГУ нефти и газа им. И.М. Губкина, 2007. 58 с.

329. Ольховская В.А., Зиновьев А.М. Влияние структурных фазовых изменений на фильтрацию высоковязкой нефти. Ашировские чтения: Сб. трудов Международной научно-практической конференции. Том II / Отв. редактор В.В. Живаева./. Самара: Самар. гос. техн. ун-т, 2012, c.160-165.

330. Запивалов Н.П. Геофлюидодинамические критерии нефтегазоносности. Фундаментальные проблемы нефтегазовой гидрогеологии: Материалы Междунар. конф., посвящ. 80-летию А. А. Карцева. М.: ГEOC, 2005, с. 81-85.

331. Hung J., Castillo, J., Reyes A. Kinetics of Asphaltene Aggregation in Toluene-Heptane Mixtures Studied By Confocal Microscopy. //Energy \& Fuels, 2005, v.19, p.898-904.

332. Дружинин В.В., Конторов Д.С. Проблемы системологии. Проблемы теории сложных систем. М., Сов. радио, 1976. 296 с.

333. Эткинс П. Физическая химия (Перевод с английского). М., Мир,1980. 293с.

334. http://barodinamika.livejournal.com/46103.html

335. Симонян Г.С. Термодинамика, бародинамика и хородинамика. Properties of matter in the focus of attention of modern theoretical doctrines Peer-reviewed materials digest (collective monograph) published following the results of the LXXXVII International Research and Practice Conference and II stage of the Championship in Physics, Mathematics, Chemistry, Earth and Space Sciences.London, August 28 - September 02, 2014) International Academy of Science and Higher Education - London: IASHE, 2014, p.25-26.

336. Simonian G. Thermodynamics, barodynamics and horodynamics // GISAP: Physics, Mathematics and Chemistry,2015, №5, p. 22-24.

337. Симонян Г.С. Хородинамика // Успехи современного естествознания, 2015, №1, ч. 7, с.1248. 
338. Симонян Г.С. Анализ состояния нафтидных систем в свете синергической теории информации // Современные наукоемкие технологии, 2014, №4, с. 108-113.

339. Короновский Н. В., Ясаманов Н. А. Планета Земля. Физикохимический состав и агрегатное состояние состояние вещества Земли. Геология: учебник для студ. учреждений высш. проф. образования. - 8е, испр. и доп. М.: Издательский центр «Академия», 2012, с. 52-53.ISBN 978-5-7695-9022-1.

340. Малышев А. И. Температурные ловушки в эндогенном цикле формирования углеводородного сырья// Ежегодник-2013, Тр. ИГГ УрО РАН, 2014, вып. 161, с. 322-327.

341. Малышев А.И. Значение фазовых переходов “газ- жидкость” в эндогенном образовании углеводородного сырья // Докл. АН, 2004, т. 399, № 3, с. 384-387.

342. Малышев А.И. Значение фазовых переходов “газ- жидкость" в эволюции высокотемпературных эндогенных флюидов // Геохимия, 2005, № 6, с. 673-680.

343. Малышев А.И. Роль охлаждающих горизонтов в генезисе углеводородных месторождений // Докл. АН, 2017, т. 476, № 4, с. 445447. DOI: $10.7868 / \mathrm{S} 0869565217280192$

344. Шеннон К. Работы по теории информации и кибернетике.М.:ИЛ, 1963. -830 с.

345. Пирумян Г., Пирумян Э., Симонян Г, Симонян А. Метод определения уровня загрязнения воды. Патент РА № 3063А (2016) (на армянском),

346. Simonyan G.S., Simonyan A. G., Pirumyan G. P. Systemicentropy approach for estimating the water quality of a river// Oxidation Communications, 2018, v.41, № 2, p.307-317.

347. Pirumyan G.P., Simonyan G.S., Margaryan L.A. Geoecological Evaluational Integrating Index of Natural Waters and other Systems. Yerevan: Copy Print LTD. 2019. 244 p.

348. Gevorg Simonyan (July 29th 2020). Systemic-Entropic Approach for Assessing Water Quality of Rivers, Reservoirs, and Lakes, In Book Inland Waters - Dynamics and Ecology, Edited by Adam Devlin, Jiayi Pan and Mohammad Manjur Shah, Intech Open, DOI: 10.5772/intechopen.87463, 2021, chapter 2, p. 19-39. DOI: 10.5772/intechopen.93220. Available from: https://www.intechopen.com/books/inland-waters-dynamics-and-ecology/systemic-entropic-approach-for-assessing-water-quality-of-rivers-reservoirs-and-lakes 
349. Simonyan G.S., Simonyan A.G., Margaryan L.A. A new approach to assessment of water quality of the Hrazdan river // Oxidation Communications, 2020, v.43, № 4, p.861-869.

350. Симонян Г. С. Анализ экологического состояния рек Гехарот, Ахверд и Гетар с помощью Армянского индекса качества воды //Вестник Приамурского государственного университета им. ШоломАлейхема 2020. №3(40), с.72-80.

351. Simonyan G.S. Entropic-systems approach to assessing the structure of COVID-19 // Oxidation Communications 2020, v.43, № 4, p.641-646.

352. Симонян Г.С., Симонян А. Г. Энтропийный подход к оценке хаоса и порядка биологических систем // Успехи современного естествознания, 2015, №9, с.100-104.

353. Симонян Г.С. Хаос и порядок биологических систем в свете синергической теории информации, Международная конференция «Современные проблемы химической физики», Ереван, 2012, с. 227228.

354. Simonyan G.S., Simonyan A. G., Sayadyan M. L., Sarsekova D. N., Pirumyan G. P.. Analysis of Environmental Status of Wood and Shrub Vegetation by the Armenian Index of Environmental Quality // Oxidation Communications, 2018, v.41, № 4, p. 533-541.

355. Симонян Г.С. Анализ состояния геоэкологических систем в свете синергической теории информации. Ordered chaos: modern problematics of physical, mathematical and chemical sciences Materials digest of the LXIII International Research and Practice Conference and II stage of the Championship in physics, mathematics and chemistry sciences (London, September 12 - September 17, 2013) Publisher and producer International Academy of Science and Higher Education.2013, p.60-63.

356. Симонян Г.С. Генезис нефти в свете синергической теории информации.// Нетрадиционные ресурсы углеводородов: распространение, генезис, прогнозы, перспективы развития. Материалы Всероссийской конференции с международным участием 12-14 ноября 2013 г. М.: ГЕОС, 2013, с. 240-243.

357. Симонян Г.С. Синергический подход к нафтидным системам. // Международный журнал прикладных и фундаментальных исследованый, 2015, №5, ч. 2, с. 270-272

358. Симонян Г.С. Оценка зрелости нефтяных залежей с помощью энтропийного индекса «Современные проблемы нефтегазовой геологии» Київ: Інституту геологічних наук НАН України, 2016, с.135-137. 
359. Simonyan G.S. Entropy approach to naphthide systems // Progress Petrochem Science. 2021, v.4, № 1, p.338-339. PPS. 000576. 2021. DOI: 10.31031/PPS.2021.04.000576

360. Немировская И.А. Нефтяные углеводороды в океане // Природа, 2008, № 3, с. 17-27.

361. Немировская И.А. Углеводороды в воде, взвесях, сестоне и донных осадках Белого моря в конце летнего периода // Водные ресурсы, 2009, т. 36, № 1, с. 68-79.

362. Немировская И.А. Сивков В. В. Особенности распределения углеводородов в юго-восточной части Балтийского моря // Океанология, 2012, т. 52, № 1 , с. 40-53.

363. Симонян Г.С. Физические и химческие процессы при трансформации нефти в гидросфере // Булатовские чтения : материалы II Международной научно-практической конференции (31 марта 2018 г.): в 7 т. : сборник статей / Под общ. ред. д-ра техн. наук, проф. О.В. Савенок. -Краснодар : Издательский Дом -Юг. Т. 5: Химическая технология и экология в нефтяной и газовой промышленности. 2018, с.275-277.

364. Позднышев Г.Н. Стабилизация и разрушение нефтяных эмульсии. М.: Недра, 1982. 220 с.

365. Воробьев Д.С. Влияние нефти и нефтепродуктов на макрозообентос // Известия Томского политехнического университета, 2006, т. 309, № 3, c.42-45.

366. Щекатурина Т.Л., Миронов О.Г. Аккумуляция углеводородов нефти двустворчатыми моллюсками Mytilus galloprovincialis L. // Гидробиологический журнал, 1987, т. 23, № 2, с. 71-76.

367. Касымов А.Г., Лиходеева Н.Ф. Накопление нефти моллюсками // Гидробиологический журнал, 1984, т. 20, № 4.с. 63-66.

368. Одинцова Т.А. Эколого-геохимические аспекты трансформации органического вещества нефтезагрязненных геосистем // Моделирование стратегии и процессов освоения гересурсов: Мат-лы Междунар. конф. Пермь: ГЙ УрО РАН, 2003, с. 241-245.

369. Одинцова Т.А. Эколого-геохимические аспекты трансформации органического вещества нефтезагрязненных геосистем // Моделирование стратегии и процессов освоения георесурсов. Сб. докла. Пермь: Горный ин-т УрО РАН, 2003, с. 241-245.

370. Давидов С.Л., Тарасов В.И. Нефть и нефтепродукты в окружающей среде. М.: РУДН, 2004. 163 с.

371. Ленинджер А. Биохимия, /пер. с англ. под ред. А.А., Баева и Я. М., Варшавского/, М.: Мир, 1974. 957 с. 
372. Starks C.M. Phase-Transfer Catalysis I.Heterogenues Reactions Involving Anion Transfer by Quaternery Ammonium and Phosponium Salts. //J.Am.Chem.Soc,1971,v.93, №1, p.195-199.

373. Mathias L.J., Waidia R.A. Inverse phase transfer catalisis.First repost of a nev class of interfasial reactions.//J.Am.Chem. soc., 1986,v.108, № 5, p.1093-1094.

374. Boyer B.,Betzer J.F., Lamaty G.,Leydet A., Roque J.-P. Invers phase catalisis I - Oxidation of a,b-Unsaturated Ketones by borhidrine in a micellar two-phase medium. //New J.Chem, 1995,v.19, p807-810.

375. Boyer B., Hambardzoumian A., Roque J.-P.,Beylerian N. Reaction in Biphasic Water/organic Solvent System in the Presence of Surfactant: Invers Phase Transfert Catalysis or interfacial Catalysis// Tetrahedron, 2000, v.56, p.303-307.

376. Симонян, Г.С., Бейлерян Н.М., Конденсация Михаэля в двухфазной системе. Применение метода обращенного межфазного катализа к реакции бутилакрилата с диэтаноламином в системе водагептан.// Кинетика и катализ, 2002, v.43, №3, p.367-370.

377. Simonian G.S., Beylerian N.M. Roque J.-P., Boyer B. Michaelis type reaction in biphasic system.Study of the Butylacrylate - Diethanolamine reaction kinetics at high stirring rates.New case of interface catalysis.//Oxidation Communication, 2004, v.27,№1, p.65-70.

378. Simonian G.S. Reactions of dipropilamine wity unsaturated surfactants in the model oil-water system. //International Journal Of Applied And Fundamental Research, 2015, № 2. URL: www.science-sd.com/46124858 (19.11.2015).

379. Симонян Г.С. Конденсационные процессы при деградации нефти в гидросфере Современная наука: актуальные проблемы и перспективы развития: монография. книга 4 / под ред. проф. Н. А. Тарасенко- Ставрополь: Логос, 2014, с.65-83.

380. Симонян Г.С., Бейлерян Н.М. Применение метода обращенного межфазного катализа для конденсации Михаэля. Новый случай автокатализа.//Тезисы докл. “Современные проблемы химической физики" Ереван, 2008, с.84-85.

381. Симонян Г.С., А.Г.Акопян А.Г., Пирумян Г.П. Конденсация михаэля в модельной двухфазной системе нефть-вода. // II международная конференция по химии и химической технологии, Ереван, 2010, с.364-365.

382. Симонян Г.С. Конденсационные процессы с участием аминов при деградации нефти в гидросфере.//Сборник материалов IV Bcepoc- 
сийской научной конференции «Переработка углеводородного сырья. Комплексные решения» (Левинтерские чтения). (3-5 ноября 2016г.) Самара: СГТУ, 2016, с.237-238.

383. Simonian G., Beylerian N. Michaels condensation in conditions of inverse transfer catalysis. Kinetic study. In:Success in Chemistry and Biochemistry Ed.G.E.Zaikov. NovaSci.Pub.Inc. New-York, 2009, v.33, p.445-452.

384. Симонян Г.С., Бейлерян Н.М., Арутюнян Р.С., Рок Ж-П, Павиа А. Кинетика реакций поверхностно - активных $\alpha, \beta$-ненасыщенных соединений со вторичными аминами в растворе.//Кинетика и катализ, 2002, т.43, №4, с.493-498.

385. Симонян Г.С., Пирумян Г.П. Геоэкологические аспекты трансформации нефти. Геология морей и океанов: //Материалы XX Международной научной конференции (Школы) по морской геологии. М: ГЕОС, 2013, c. 266-269.

386. SimonianG. S. The reaction of N[tri (hyroxymethyl)methane] acrylamide with decylamine in conditions of inversphase transfer catalysis. fractal structureof the reaction product" // 20135th International Sympostium on the Chemistry of Natural Compounds. Tashktnt-Bukhara, 2013, p. 277. http://www.icps.org.uz

387. Симонян Г.С., Реакция Михаэля в модельной двухфазной системе «нефть- вода». А particular case in conditions of limitlessness: earth in the vast Universe. Peer-reviewed materials digest (collective monograph) published following the results of the LXXIV International Research and Practice Conference and III stage of the Championship in Earth and Space sciences, Physico-mathematical and Chemical sciences (London, December 19 - December 24, 2013). Publisher and producer International Academy of Science and Higher Education, 2014, p.109-111.

388. Симонян Г.С., Бейлерян Н.М, Чобанян Ж.Н., Саргсян А. Р., Гзырян А.Г. Применение метода обращенного межфазного катализа к реакции $\mathrm{N}-[($ тригидроксиметил)метил]амид акриловой кислоты-тетрадециламин в двухфазной системе вода-гептан.// Информационные технологии и управление, 2004,№4-1, с.76-79.

389. Torosyan G.. Harutyunyan A., Isakova L., Beylerian N., Chobanyan J., Simonian G. Reaction of acetoacetic acid ester with acryl-and $\alpha$-methylacrylamides in conditions of inverse phase transfer catalysis. Effect of surfactants type .//Oxidation Communication, 2007, v.30, № 3,p.548-552.

390. Торосян Г.О., Алексанян А.Р., Исакова Л.А., Чобанян Ж.Н. Симонян Г.С. Взаимодействие эфира ацетоуксусной кислоты с акрил- и $\alpha$ - метакриламидами в присутствии четвертичных аммониевых солей 
//Известия высших учебных заведений. // Химия и химическая технология. Научно- технический журнал, 2007, т. 50, вып.11, с.28-31.

391. Арутюнян Р.С., Амбарцумян А.Ж., Симонян Г.С., Бейлерян Н.М. Влияние добавок и температуры на закономерности миццелообразования бромида додецилтриметиламмония в водной среде./Уч.зап. ЕГУ, 1999, №2, с.70-73.

392. Симонян Г.С., Чобанян Ж.Н., Саргсян А. Р., Гзрян А.Г., Бейлерян Н.М. Распределение ряда аминов в водноорганической двухфазной системе.// Информационные технологии и управление, 2003, №3, c.86-89.

393. Симонян Г.С., Арутюнян Р.С., Бейлерян Н.М., Григорян Э.А. Синтез новых поверхностно-активных $\beta$-аминов на основе $\mathrm{N}$-[три(гидроксиметил)метил]амида акриловой кислоты - закрепителей красителей на хлопковых волокнах.// ЖПХ, 2003, т.76, вып.2, с.266-268.

394. Simonian G.S., Beyleryan N.M. The solvent action on michaelis reaction Rate. A New parameter concerning the solvent polarity. // Oxidation Communication, 2003, v. 26, №4, p. 485-491.

395. Симонян Г.С. Реакции диэтиламина с поверхностно-активными непредельными амидами кислот в модельной системе нефть - вода // Технология нефти и газа, 2014, №1, с.45-48.

396. Симонян Г.С., Пирумян Г.П. Изучение реакций поверхностноактивных ненасыщенных соединений с метилэтаноламином в модельной системе нефть-вода. // Экологическая химия, 2014, т.23, вып. 1, c. $40-43$.

397. Симонян Г.С. Геоэкологический подход к трансформации нефти в гидросфере. Глобализация, региональное развитие и проблемы окружающей среды: сборник материалов международной научно-практической конференции (сентябрь, 2013 г.) - Южно-Сахалински: изд-во сахгу, 2013, с. 75-77.

398. Симонян Г.С., Бейлерян Н.М. Параметры Альфрея-Прайса как критерии реакционной способности $\alpha, \beta-\mathrm{HC}$ в реакции со вторичными аминами.//Химич.журн.Армении, 2001,т.54, №3-4,с.130-132.

399. Dimroth K., Reichardt C. Erweiterung der Losungsmittelpolaritatsskale durch Verwendung Alkyl-substituierter Pyridinium-N-phenolbetaine. // Liebigs Ann.Chem., 1969, B.727, p. 93-105.

400. Симонян Г.С., Бейлерян Н.М. Кинетика реакции ненасыщенных нитрилов и эфиров кислот с вторичными аминами.//Кинетика и катализ, 1997, т.38, №1, с.32-35.

401. Симонян Г.С., Налбандян Дж.М., Согомонян Б.М., Бейлерян Н.М. Влияние продуктов окисления аминоспиртов на констант ингибирования окисления кумола.//Арм.хим.ж.,1990,т.43,N2,с.84-88. 
402. Симонян Г.С., Пирумян Э.Г., Хачатрян А.Г., Бейлерян Н.М. Количественная трактовка влияния строения третичных аминов на ингибирующее действие при окислении кумола.//Информационные технологии и управление, 2000, №2, с.168-174.

403. Симонян Г.С. Окисление кумола в присутствии третичных аминов Peer-reviewed materials digest (collective monograph) published following the results of the CL International Research and Practice Conference and II stage of the Championship in Physics and Mathematics, Chemistry, Earth and Space Sciences (London, October 18 - October 24, 2017) 2016 International Academy of Science and Higher Education (London, UK)Published by IASHE London, 2017, p.7-8.

404. Симонян Г.С., Пирумян Э.Г. Окислительные процессы при деградации нефти в гидросфере. //Геология морей и океанов: Материалы XX Международной научной конференции (Школы) по морской геологии.T.IV - М: ГЕОС, 2015, с. 196-199.

405. Пирумян Э.Г., Симонян Г.С., Бейлерян Н.М. Влияние строения третичных аминов на скорость реакции со свободными радикалами ОН. //Информационные технологии и управление, 2000, №4, с.10-14.

406. Пирумян Э.Г., Симонян Г.С., Бейлерян Н.М. О связи между константой скорости реакций аминов со свободными радикалами ОН. и потенциалом ионизации.//Уч.зап.ЕГУ, 2000, №2, с.126-127.

407. Пирумян Э.Г., Симонян Г.С., Пирумян Г.П., Бейлерян Н.М. О самоочищении водной среды с участием свободных ОН.-радикалов. //"Экватэк-2000", тезисы докладов IV Международного конгресса "Вода: экология и технология", Москва, 2000, с.151.

408. Пирумян Э.Г., Пирумян Г.П., Симонян Г.С., Бейлерян Н.М. Оценка способности самоочищению природной водных объектов Республики Армении в отношения различных пестицидов и метаболитов их трансформации.//Тезисы докладов IV Международного симпозиума "Чистая вода России 2001, Екатринбург, 2001, с.69.

409. Эмануэль Н.Н., Денисов Е.Т., Майзус З.К. Цепные реакции окисления углеводородов в жидкой фазе, М.: Наука, 1965. 375с.

410. Беляков В.А., Налбандян Дж.М., Бейлерян Н.М. Исследование ингибирующего действия диэтилэтаноламина и триэтиламина при окислении этилбензола и кумола методом хемилюминесценции и по поглащению кислорода. //Нефтехимия, АН СССР, 1982, №4, с.494-496.

411. Симонян Г.С., Пирумян Г.П., Симонян А.Г. О некоторых закономерностях загрязнения водосборного бассейна озера севан нефтепродуктами //Научные основы охраны окружащей среды, Сборник статьей, Пенза, 2010, с.100-102. 


\section{СОДЕРЖАНИЕ}

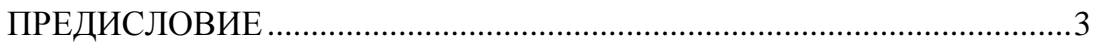

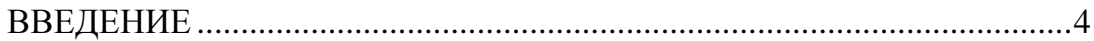

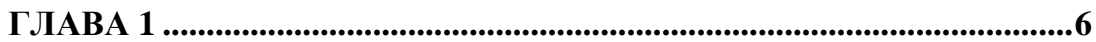

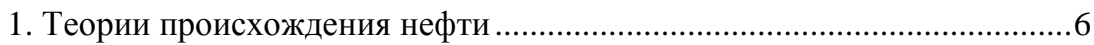

1.1. Биогенная теория образования нефти ……….....................................6

1.2. Абиогенная теория образования нефти ............................................8

1.3. Аргументы против биогенной теории образования нефти ...............27

1.3.1. Наличие местораждения нефти в фундаментальных

кристаллических породах и ниже так называемого «нефтяного окна»..29

1.3.2. Соотношения $\mathrm{C} / \mathrm{H}$ при переходе от нефтеобразующего

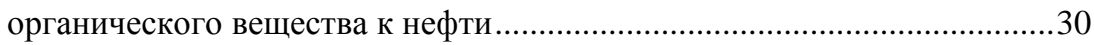

1.3.3. Наличие металлов и их соединений, в частности VO- и Ni-

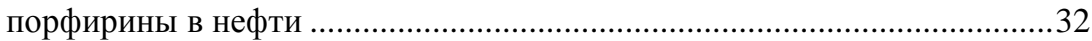

1.3.4. Совместное нахождение соли и нефти в форме залежей ................35

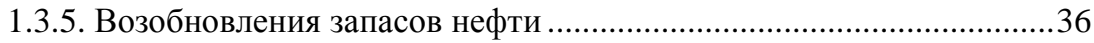

1.3.6. Органические составляющие нефти в космосе ...............................36

1.3.6.1. Органическое вещество в метеоритах и кометах ...........................38

1.3.6.2 Органическое вещество в составе планет и экзопланет ...............42

1.3.6.3. Органическое вещество в межзвездной среде.............................49

1.3.6.4. Химические реакции в межзвездной среде ...................................53

1.4. Физико-химические свойства нефти и газа ....................................59

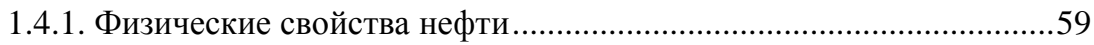

1.4.2. Фракционный состав нефти и продукты переработки нефти .........62

1.4.3. Химическая и технологическая классификация нефтей .................64

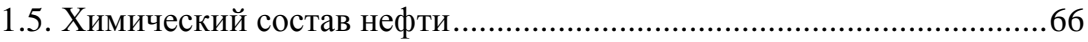

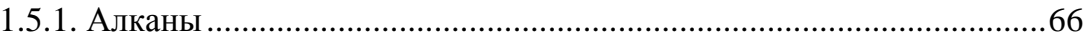

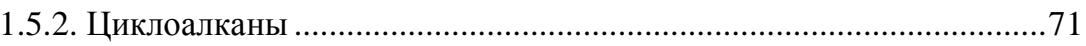

1.5.3. Ароматические углеводороды-арены.........................................73

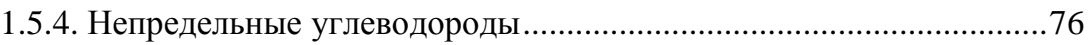

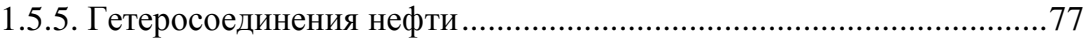

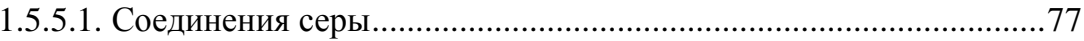

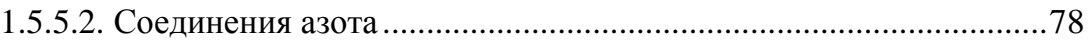

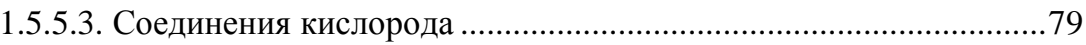

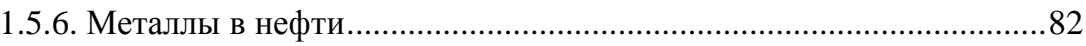




\section{ГЛАВА 2}

Роль C-H-O- S - N -V-NI системы в генезисе абиогенной нефти ........85

2.1. Роль С-Н-О системы в генезисе нефти ...............................................85

2.1.1. Процесс Фишера-Тропша и другие в генезисе нефти .....................85

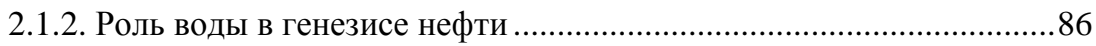

2.1.2.1. Представление об аномальных и специфических свойствах

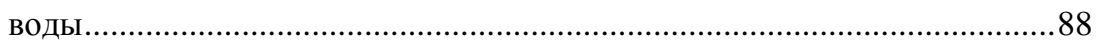

2.1.2.2. Химические реакции образования нефти с участием воды ........94

2.2. Роль C-H-O-S системы (серы) в генезисе нефти .................................96

2.3. Роль C-H-O- S -N системы (азота) в генезисе нефти .........................97

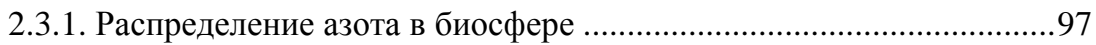

2.3.2. Закономерности распределения азота в нефти..............................100

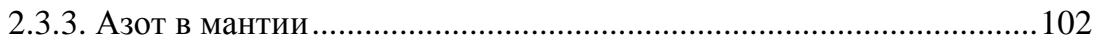

2.3.4. Химические реакции образования нефти с участием азота .........104

2.4. Роль ванадия и никеля в генезисе нефти ........................................ 108

2.4.1. Распределение ванадия и никеля в литосфере и в нефти .............108

2.4.2. Роль металлопорфиринов ванадия и никеля в генезисе нефти....113

2.4.2. Совместная роль геокосинергической системы S - N - V-Ni в

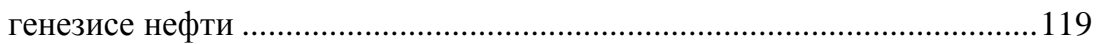

\section{ГЛАВА 3}

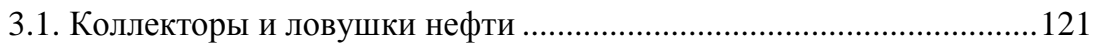

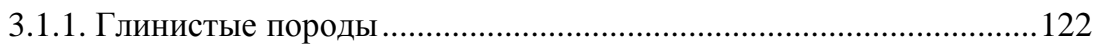

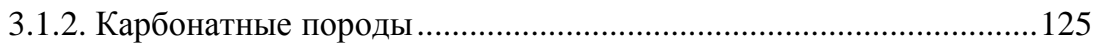

3.1.3. Вулканогенно - осадочные породы ............................................... 125

3.1.4. Кристаллические соляные породы ...............................................126

3.1.5. Классификация коллекторов и свойства горных пород ................126

3.1.6. Классификация залежей нефти и газа ...........................................130

3.2. Пластовые воды нефтегазовых месторождений .............................133

3.3. Роль воды в миграции УВ и образования залежей нафтидов ..........135

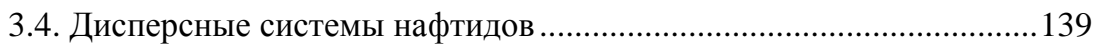

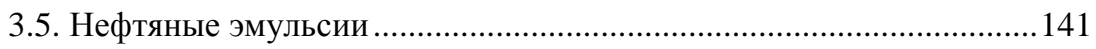

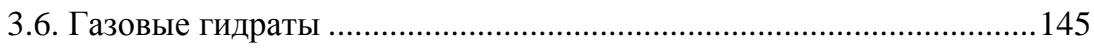

3.7. Адсорбция углеводородов на глинистых минералах ......................149

\section{ГЛАВА 4}

4.1. Методы обнаружения нефтяных залежей.......................................154 


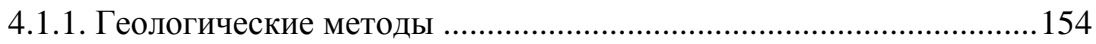

4.1.2. Геофизические исследования и виды поиска ................................155

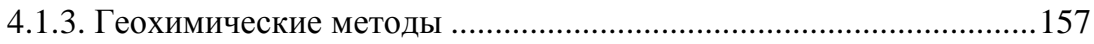

4.2. Биогеофизический и комбинированные методы поиска

месторождений углеводородов ......................................................... 161

4.3. Геоэкологические аспекты повышения нефтеотдачи пластов ........166

4.4. Новый метод обнаружения нефтяных залежей ..............................172

\section{ГЛАВА 5}

Залежи нефтей и нефть как фрактальная, хородинамическая и геонформационная система ..........................................................179

5.1. Фрактальность нефтяных залежей и нефти ....................................179

5.1.1.Фрактальные и дендритные структуры геологических объектов 179 5.1.2. Фрактальность нефтяных месторождений, вмещающих

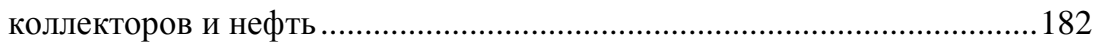

5.2. Залежи нефти и газа как хородинамическая система .......................190

5.3. Оценка зрелости нефтяных залежей с помощью энтропийного

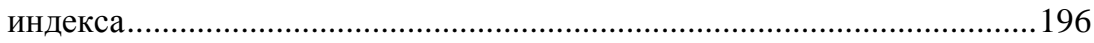

\section{ГЛАВА 6}

Загрязнение и деградация нефти в гидросфере.......................................202

6.1. Загрязнение гидросферы нефтью и нефтепродуктами .....................202

6.2. Деградация нефти в гидросфере......................................................204

6.3. Физические процессы при трансформации нефти в гидросфере ...205

6.4. Влияние нефти на гидробионты и биохимические процессы при трансформации нефти в гидросфере ..................................................208

6.5. Химические процессы при деградации нефти в гидросфере..........212

6.5.1. Конденсация Михаэля в двухфазной системе...............................2215

6.5.1.1. Кинетические закономерности реакции БА+ДЭолА в двухфазной системе гептан - вода ...................................................217

6.5.1.2. Кинетические закономерности реакции водорастворимое $\mathrm{HC}+$ амин в двухфазной системе гептан - вода...........................................223

6.5.1.3. Реакции аминов с поверхностно - активными непредельными амидами кислот в модельной системе нефть - вода...............................230 6.5.1.4. Реакция эфира ацетоуксусной кислоты с акрил - и метилакриламидами в водно-щелочном растворе в присутствии четвертичных аммониевых солей 
6.5.2. Окислительные и фотохимические реакции при деградации

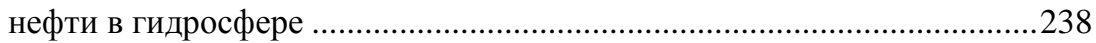
6.5.2.1. Окисление кумола в присутствии аминов в модельной системе «нефть - вода» 239 6.5.2.2. Реакция ОН радикалов с метаболидами конденсационной деградации нефти (аминами) в модельной системе «нефть- вода» .......241 6.6. О некоторых закономерностях загрязнения нефтепродуктами на примере реки Раздан и озера Севан ... 244 Активные участники форума «Глубинная нефть» и конференций Кудрявцевские Чтения, чьи работы были обсуждены в книге 247 ЛИТЕРАТУРА .248 


\section{Симонян Г.С., Пирумян Г.П.}

\section{НОВОЕ СУЖДЕНИЕ \\ О ГЕНЕЗИСЕ НЕФТИ}

Формат 60x84/16. Объем 18 печ.л.

Бумага-офс. 80 г. Офсетная печать

Тираж 300 экз.

Печатано в типографии COPYPRINT LTD 